\title{
RE:VISÃO: Habitat nos anos 1960
}

Dissertação para obtenção do título de Mestre em A r q u i t e t u ra e Urban is mo

Programa de Pós-Graduação em Teoria e História da Arquitetura e Urbanismo Núcleo de Estudos de Habitares Interativos - Nomads.usp

\section{Elza Luli Miyasaka Orientadora: Profa. Dra. Anja Pratschke}

Escola de Engenharia de São Carlos a Universidade de São Paulo 



\title{
Universidade de São Paulo \\ Escola de Engenharia de São Carlos \\ Departamento de Arquitetura e Urbanismo
}

Programa de Pós-Graduação em Teoria e História da Arquitetura e Urbanismo

Núcleo de Estudos de Habitares Interativos - Nomads.usp

\section{RE:VISÃO:Habitat nos anos 1960}

\author{
Dissertação apresentada à Escola \\ de Engenharia de São Carlos da \\ Universidade de São Paulo para \\ obtenção do título de Mestre \\ em Arquitetura e Urbanismo \\ Área de Concentração: Teoria e \\ História da Arquitetura e Urbanismo
}

Aluna: Elza Luli Miyasaka Orientadora: Profa. Dra. Anja Pratschke 
AUTORIZO A REPRODUÇÃO E DIVULGAÇÃO TOTAL OU PARCIAL DESTE TRABALHO, POR QUALQUER MEIO CONVENCIONAL OU ELETRÔNICO, PARA FINS DE ESTUDO E PESQUISA, DESDE QUE CITADA A FONTE.

Ficha catalográfica preparada pela Seção de Tratamento da Informação do Serviço de Biblioteca - EESC/USP

M685r

Miyasaka, Elza Luli

RE:VISÃO : habitat nos anos 1960 / Elza Luli

Miyasaka ; orientadora Anja Pratschke. -- São Carlos, 2011.

Dissertação (Mestrado - Programa de Pós-Graduação em Arquitetura e Urbanismo e Área de Concentração Teoria e História da Arquitetura e Urbanismo) -- Escola de Engenharia de São Carlos da Universidade de São Paulo, 2011 .

1. Habitação. 2. 1960. 3. Sociedade da informação.

4. Megaestrutura. 5. Cápsula. 6. Produção seriada.

I. Título. 
FOLHA DE JULGAMENTO

Candidato(a): Bacharel ELZA LULI MIYASAKA.

Dissertação defendida e julgada em 03/05/2011 perante a Comissão Julgadora:

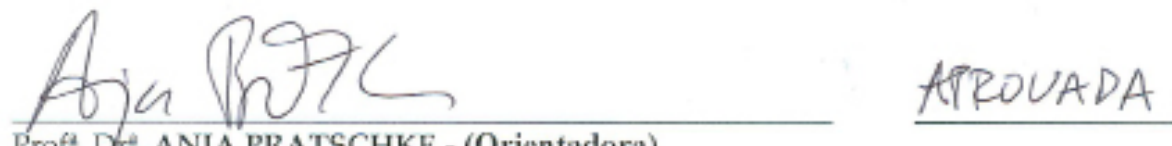

Prof ${ }^{2}$. Dr 4 . ANJA PRATSCHKE - (Orientadora) (Instituto de Arquitetura e Urbanismo/USP)

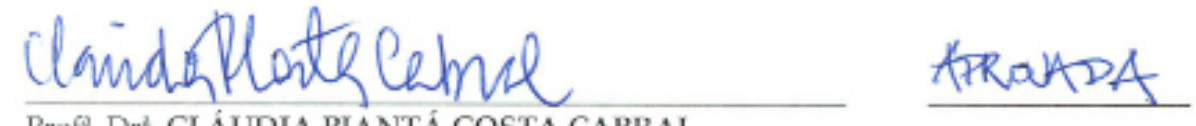

Prof?. Dr ${ }^{2}$. CLÁUdIA PIANTÁ COSTA CABRAL (Universidade Federal do Rio Grande do Sul/UFRGS)

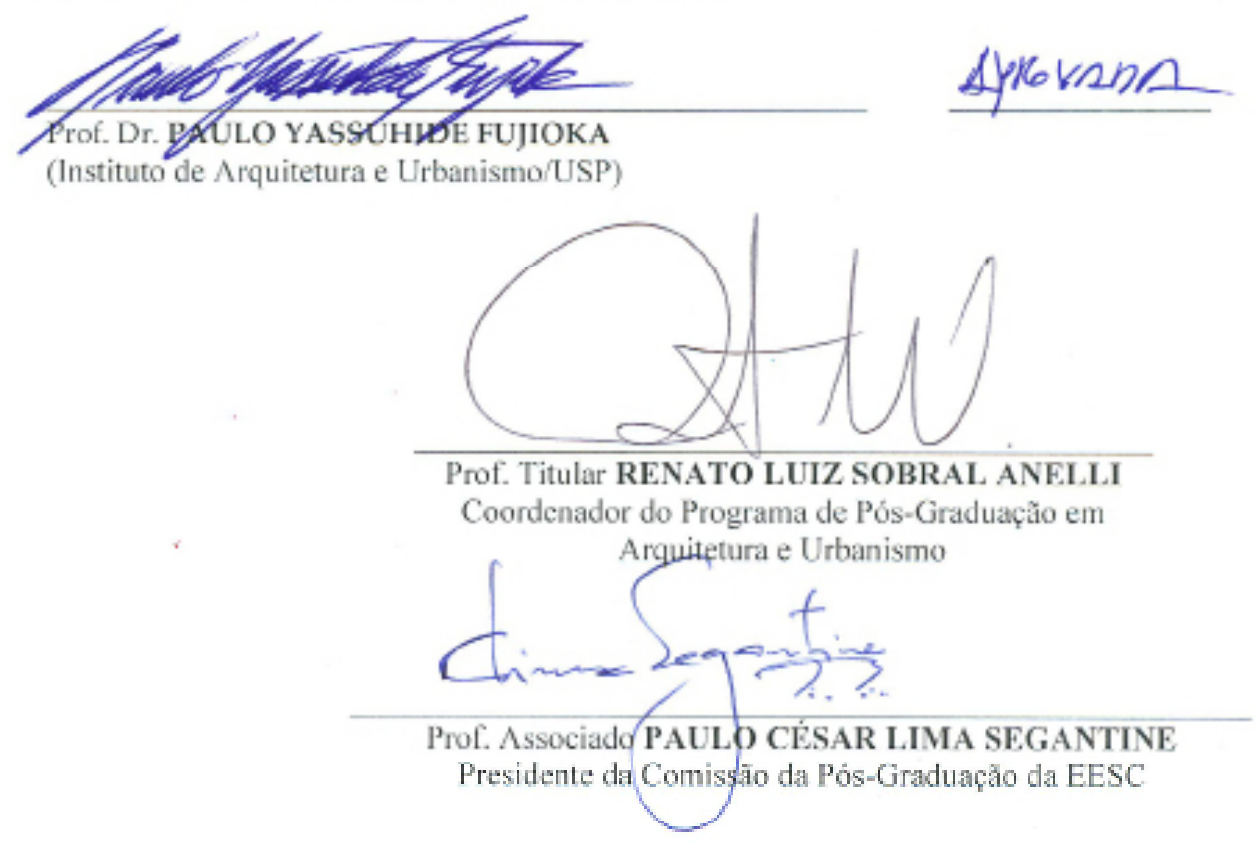



Dedico às mulheres que fazem a diferença em minha vida: Minha mãe Tereza Miyasaka, Marialva Manfrin, Cristina Miyasaka, Fernanda Silva Miyasaka, Salete Baptistini e Tokico Murakawa Moriya. 
Akio Tony Miyasaka Luiz Yukio Miyasaka Alberto Minoru Miyasaka A Heck Alice Gomes Heck Érika Moretini Marco Al Lima Arquiteto Waldir Gozalez Bulhon Luberto Moreira Ana Carlos Cecilio Batista Oliveira Profa. Dra. Tokico Mur Fátima M. do N. L. L. Mininel Evandro César Bueno José Edı Gregore Candalez Paulo Cesar Albertini CEPLAN UnB TorresAlessandroM. deSouzaFelipeAnitellíGeraldoDonizettiPerei AntonioJ oãoTessarin MartaTrevisan Prof. Dr. FranciscoSalesTraja Prof. Dr. Márcio Minto Fabrício CEDOC UnB Prof. Dr. José Buzzar Prof. Dr. Paulo César Castral Prof. Dr. Paulo Profa. Dra.Carmem Mafuf Departamento Arquitetura Meus irmãos minha família Bene Denise Monaco dos Santos Dra.Va Rodrigo Minot Gutierrez Prof. Dr. Hugo Segawa Mathi Marquetto o Programa de Pós-Graduação Bruna Maria Biagioni Bruno Alves Ariane Paeró D'Andrea Sérgio Celestin Lucas Zamb Alan de Oliveira Dra. Akemi I no Ana Paula Carvalho Andrei Ba Carolina Passos de Oliveira Santos Priscilla Thais Marqu Sanches Prof.Dr.Henrique Takashi Moriya Gabriel 
Akemi Cristina Miyasaka Tânia Cristina Registro Leila ntonio de Almeida Arquiteto João Filgueiras Carolina Michele Michelli Marlon Mercaldi Juliano 'akawa Moriya Marcelo Celestini Sérgio Carlos Celestini ıardo Zanardi Marialva Manfrin Oswaldo de Andrade Paulo VictorSouza Cenevivaj oséRenato Dibo CNPQ Lucinda deBrito raProfa.Dra.Anja PratschkeProfa. Dra. CibeleSalibaRizek noFilhoNomads.USProfa. Dra. MariaÂngelaP. C. S. Bortolucci :arlos Bezzon Prof. Dr. Miguel AGRADECIMENTOS Antonio Yassuhide Fujioka Prof. Dr. Azael Rangel Camargo a e Urbanismo Tereza Miyasaka Graziele Lautenschlaeger Irlete Benevente Prof. Dr. Rui Sardinha Prof. Dr. Renato Anelli eu Perrin Rodrigo Peronti Santiago Gabriela Carneiro Thais Prof. Dr. Marcelo Tramontano Gilfranco Medeiros ianchi Rodrigo Schmidt Seminari Fábio Abreu de Queiroz irbosa da Silva Zanetti Cynthia Nojimoto Camila Gonçalves etto Edmundo Macha João Paulo Marquesini Soares Vitor Locilento Nery Prata Mayara Dias de Souza Daniel Morais Pachoalin 


\section{ABSTRACT}

Miyasaka, E. L. (2011). RE:V/SÃO: Habitat nos anos 1960. 310p. Dissertação (Mestrado em Arquitetura e Urbanismo) - Escola de Engenharia de São Carlos, Universidade de São Paulo, São Paulo, 2011.

The objective of this essay is to comprehend the guiding principles of habitation in the 1960s through the analysis of the city with Yona Freidman's megastructures; of Kisho Kurokawa didatic materials regarding capsules; and J oão Filgueiras Lima's production process through industrialization. The megastructures of Yona Friedman were structures with functions of a city, utilized emerging technologies and their objective was to shelter the population in a living space. The flexibility of the environments, the user's mobility and participation were fundamental. The Capsules, components of the living, involucres to the human living and industrially produced, proposed autonomy and symbiosis between man and machine. The Industrialization was comprehended as an instrument to achieve fariness and result of the collective social conscience. To Lima, the habitat is composed by the necessary parts for the human development, composed by the urbanization, habitation and social equipments.

Keywords: 1. living in architecture, 2. 1960, 3. architecture and information society, 4. megastructures, 5 . capsule, 6 . serial production. 


\section{RESUMO}

Miyasaka, E. L. (2011). RE:V/SÃO: Habitat nos anos 1960. 310p. Dissertação (Mestrado em Arquitetura e Urbanismo) - Escola de Engenharia de São Carlos, Universidade de São Paulo, São Paulo, 2011.

O objetivo do trabalho é compreender alguns princípios norteadores do habitat na década de 1960 através da análise da cidade com as megaestruturas de Yona Friedman; da análise do material teórico de Kisho Kurokawa sobre as cápsulas; e sobre o processo de produção através da industrialização de J oão Filgueiras Lima - Lelé. As Megaestruturas de Yona Friedman eram estruturas com funções de cidade, utilizavam tecnologias emergentes e o objetivo era acolher a população como espaço do habitar. As Cápsulas eram componentes do habitar, envoltórios ou invólucros para o habitar humano, produzidos industrialmente, propunham a autonomia e simbiose entre máquina e homem. A Industrialização para J oão Filgueiras Lima era compreendida como instrumento para atingir a equidade e resultado da consciência social e coletiva. Para Lima, o habitat era constituído pelas partes necessárias para o desenvolvimento do ser humano, composto pela urbanização, habitação e equipamentos sociais.

Palavras chave: 1. Habitação, 2. 1960, 3. Sociedade da informação, 4. Megaestruturas, 5. Cápsula, 6. Produção seriada. 


\section{Sumário}

$\begin{array}{ll}\text { ABSTRACT } & 8\end{array}$

RESUMO 9

1. INTRODUÇÃO 13

2. MEGAESTRUTURAS 27

2.1. Contextualização do Momento 35

2.2. Sobre a vida de Yona Friedman 39

2.3. Conceitos do Habitat 57

2.3.1. O Espaço da Urbanidade $\quad 60$

2.3.2. A Influência da Cibernética nas cidades 71

2.3.3. A casa $\quad 75$

2.4. Abordagem Metodológica $\quad 79$

2.5. O Pensar sistêmico e o exemplo do Flatwriter 86

2.6. Sérgio Bernardes no Brasil $\quad 94$

$\begin{array}{ll}\text { 2.7. Considerações } & 101\end{array}$

3. CÁPSULAS 103

3.1. Contextualização do habitar japonês 112

$\begin{array}{ll}\text { 3.2. Influências para a Arquitetura } & 129\end{array}$

3.3. Sobre a vida de Kisho Kurokawa $\quad 144$

$\begin{array}{lll}\text { 3.4. Conceitos de habitat } & 160\end{array}$ 
3.4.1. A cidade por Kurokawa 161

3.4.2. Os princípios das cápsulas, segundo Kurokawa 170

3.5. O Nakagin Capsule Tower 179

3.6. A Casa Bola No Brasil 197

3.7. Considerações 192

4. INDUSTRIALIZAÇÃO 195

4.1. Contextualização Histórica 197

4.2. Aspectos intrínsecos da industrialização 204

4.2.1. A Coordenação Modular e o Ciclo Aberto ou Fechado 205

4.2.2. A Racionalização 208

4.3. Sobre a vida de J oão Filgueiras Lima $\quad 210$

4.4. A Teoria Geral de Sistemas (TGS) 219

4.5. Conceito de Habitat 222

4.6. A Consciência Social e Coletiva como princípio nortea dor 224

4.7. O Processo Industrializado - Alojamento - Colina 237

4.8. Considerações 266

5. CONSIDERAÇÕES FINAIS 269

6. BIBLIOGRAFIA 277

7. ANEXOS 291

8. LISTA DE FIGURAS 299 


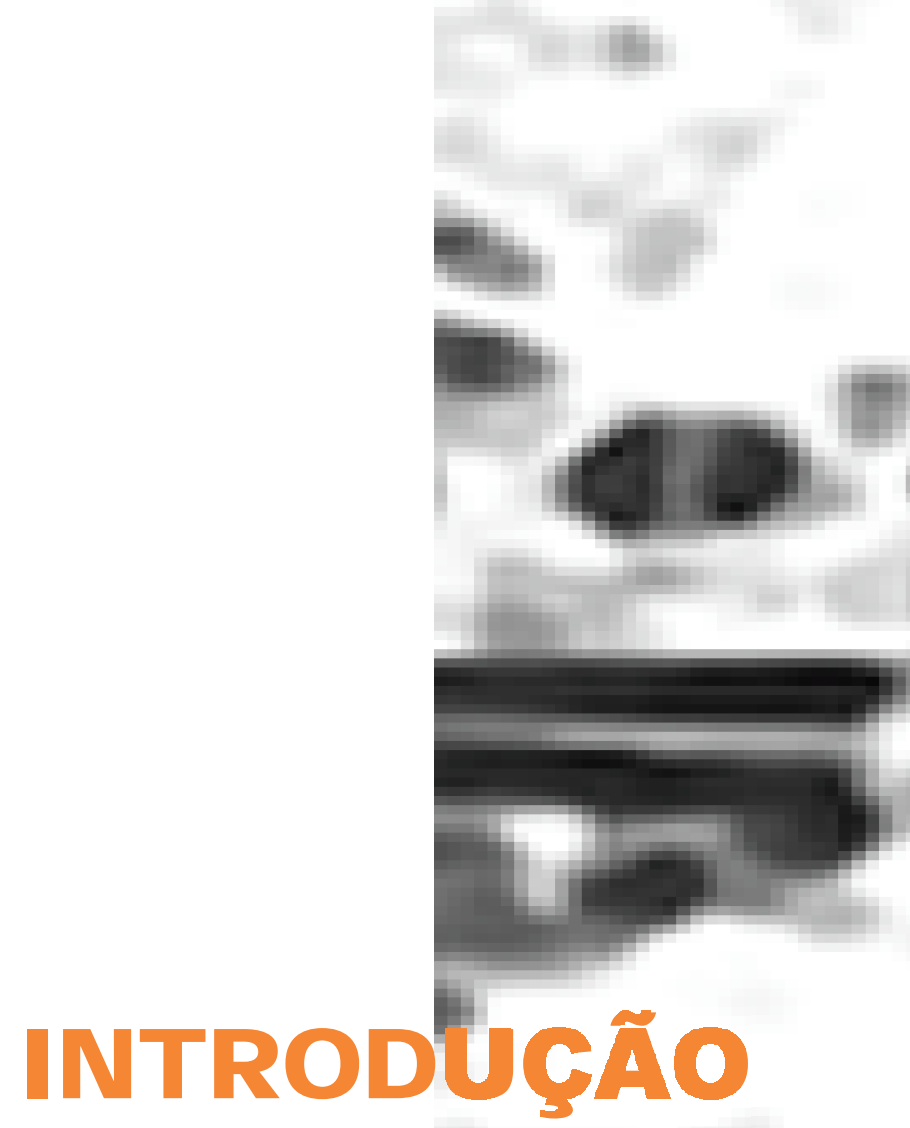



Este trabalho é resultado de pesquisa de mestrado e tem como intuito compreender alguns princípios norteadores do conceito do habitat nos anos 1960. Optou-se por analisar esta temática do habitat a partir da escala da cidade, da moradia e do processo produtivo na costrução civil. Para tal, pretende-se discorrer sobre as megaestruturas como modelo urbano, suporte do habitar, a reconfiguração do espaço de habitação na forma de cápsula e a revisão do processo de construção seriada que foi o meio utilizado para responder à demanda por habitações. Para a discussão de cada temática, elegeram-se três arquitetos: o urbanista francês Yona Friedman, o arquiteto japonês Kisho Kurokawa e o arquiteto brasileiro J oão Filgueiras Lima.

A investigação deve alimentar as linhas de pesquisa, processos de designe espacialidades concretas dentro do Nomads.usp - Núcleo de Estudos de Habitares Interativos. Espera-se contribuir para o entendimento das configurações do habitat, do processo de designe de comunicação nos anos 1960.

O interesse pela área de habitação surgiu na graduação. Naquela época a mestranda aproximou-se do tema habitação de interesse social para o desenvolvimento do trabalho de conclusão de curso. A mestranda preocupava-se com a qualidade dos espaços da habitação, e considerava que estes espaços não estavam relacionados somente com o espaço físico edificado, mas com outros fatores que incluíam organização, acolhimento e disponibilidade de equipamentos ou serviços.

O Nomads.usp ${ }^{1}$ dedica-se ao tema do habitar desde a sua constituição em 2000 e enquanto grupo de pesquisa:

Entende o habitar como território onde se desenvolvem múltiplos aspectos do cotidiano do habitante urbano, onde ações e espacialidades se combinam e interagem, e processos de comunicação

1 Grupo de pesquisa coordenado pelos professores Dr. Marcelo Tramontano, Dra. Anja Pratschke e Dra. Varlete Benevente do Instituto de Arquitetura e Urbanismo de São Carlos. 
de diferentes naturezas se efetivam. Desses processos deriva uma grande diversidade nas maneiras como esse habitar se configura, permitindo imprimir-lhe um caráter inequivocadamente plural. $\mathrm{O}$ adensamento de sua espacialidade concreta pelo aporte de instâncias virtuais produz espacialidades híbridas. Regidas por dinâmicas próprias e recentes, que constituem atual matéria prima da arquitetura e do design e situam-se no centro dos interesses das pesquisas do núcleo (NOMADS.USP, 2005).

Vários autores trabalham com a questão da habitação, mas neste trabalho elegeu-se mencionar alguns que se aproximam do entendimento desenvolvido na pesquisa.

Conforme descreveu Villém Flusser (1920-1991),

Morar não é dormir em cama imóvel, mas viver em ambiente habitual.

O lar não é lugar fixo, mas ponto de apoio merecedor de confiança (FLUSSER, 1983, p.73).

Flusser abordou o espaço de morar como local habitual, espaço que se permanece em vários momentos. Ambiente em que se possa sentir à vontade, provido de segurança e capaz de proporcionar certo acolhimento.

O filósofo Martin Heidegger (1889-1976) descreveu o habitar como:

[...] permanecer pacificado na liberdade de um pertencimento, resguardar cada coisa em sua essência. $O$ traço fundamental do habitar é esse resguardo (HEIDEGGER, 2006², p. 126).

O filósofo alemão disse ainda que construir significava originalmente habitar, e esse "tonstruir significa cuidar do crescimento que, por si mesmo, dá tempo aos seus frutos. No sentido de proteger e cultivar, construir não é o mesmo que produzir" (HEIDEGGER, 2006, p. 126). Para Choay (20003), Heidegger fazia parte de uma

2 Este texto de Heidegger foi apresentado pela primeira vez em Darmstadt, Alemanha em 1951.

3 Primeira publicação 1965. 
corrente culturalista 4 , em que habitar queria dizer, estar na terra, ser o cotidiano do homem, ser o habitual.

\author{
Já para o arquiteto holandês Herman Hertzberger (n. 1932), o habitar estava \\ intimamente relacionado com o senso de responsabilidade no envolvimento e no \\ mobiliamento de uma área:
}

Um "ninho seguro" - um espaço conhecido à nossa volta, onde sabemos que nossas coisas estão seguras e onde podemos nos concentrar sem sermos perturbados pelos outros - é algo de que cada indivíduo precisa tanto quanto o grupo.

Sem isso, não pode haver colaboração com os outros. Se você não tem um lugar que possa chamar seu, você não sabe onde está (HERTZBERGER ${ }^{5}, 1999$, p. 28).

\title{
O crítico e estudioso Reyner Banham, nos anos 1960, evidenciou o pensamento dessa época quando comentou sobre a casa e seus equipamentos:
}

Quando sua casa contém um complexo sistema de tubulações, fluxos, dutos, luzes, entradas e saídas, fornos, pias, refletores de alta fidelidade, antenas, canais, aquecedores, condicionadores - quando essa contém tantos serviços que o hardware poderia se levantar sem nenhuma assistência da casa, por que ter uma casa para envolver isso ${ }^{6}$ (BANHAM, 1969, p.501, tradução nossa).

Os ambientes-abrigo com unidades de serviço separadas apareciam em várias propostas arquitetônicas desse período, como descreveu Banham; espaços fixos,

\footnotetext{
4 [...] Seu ponto de partida crítico não é mais a situação do indivíduo, mas a do agrupamento humano, da cidade. Dentro desta, o indivíduo não é uma unidade intermutável como no modelo progressista; por suas particularidades e sua originalidade própria, cada membro da comunidade constitui, pelo contrário, um elemento insubstituível nela. [...] (CHOAY, 2003, p. 11)

5 O livro é um apanhado de palestras desenvolvidas pelo autor a partir de 1973 na Universidade Técnica de Delft.

6 Original em inglês: When your house contains such a complex of piping, flues, ducts, wires, lights, inlets, outlets, ovens, sinks, refuse disposers, hi-fi reverberators, antennae, conduits, freezers, heaters -- when it contains so many services that the hardware could stand up by itself without any assistance from the house, why have a house to hold it up?
} 


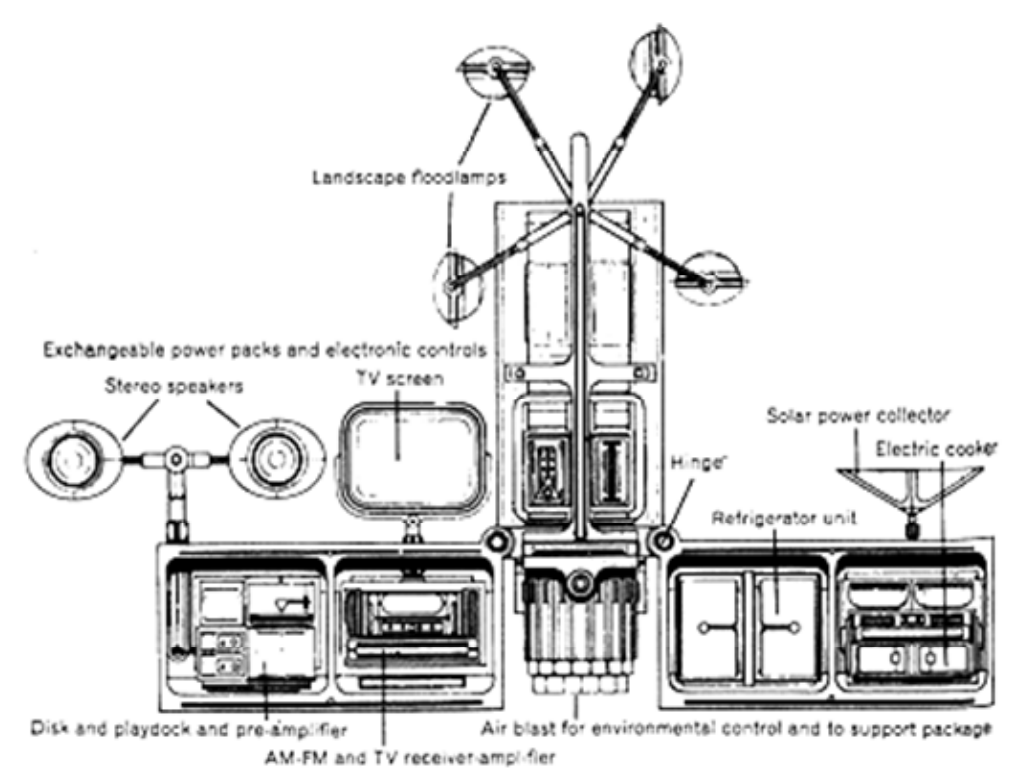

Figura 1: A home is not a house.

Fonte: (BAN HAM, 1969, p. 46.)

delimitados e estáticos eram cada vez mais inadequados para as atividades do cotidiano. A casa deveria incluir um núcleo de serviços com um espaço infinito em todas as direções, um pacote padrão de vida transportável, com ar condicionado, televisão conectada em rede, energia solar, iluminação, e outros eletrodomésticos básicos (BANHAN, 1969, p. 46).

Como descreve o estudioso sobre Banham, Nigel Whiteley; Banham previa que a tecnologia tomava possível,

[...] definir 'casa' sem fazer referência à lareira ou ao telhado, mas simplesmente como a integração de um complexo de relações intrapessoais e serviços de alimentação ${ }^{7}$ (WHITELEY, 2002, p. 203, tradução nossa).

7 Original em inglês: [...] define 'home' without reference to hearth or roof, but simply as the integration of a complex of intrapersonal relationships and mains services. (WHITELEY, 2002, p. 203) 
Etmologicamente, segundo o dicionário de Ferreira (1986), o verbo Habitaré de origem latina, habitare, e tem como sinônimos residir, morar, tornar habitado, ocupar, viver, estar, permanecer. A palavra Habitação significa espaço físico construído. J á o termo Habitaté utilizado principalmente na ecologia e refere-se ao lugar no qual um organismo vive, ou ainda, a certas características ecológicas do lugar específico, habitado por um organismo vivo ou por uma população. E finalmente, Hábito significa disposição duradoura, adquirida pela repetição frequente de um ato, uso ou costume. Ferreira (1986) considera que o habitaté a junção de condições favoráveis ao desenvolvimento dos seres vivos em seu ambiente físico. E a definição de Ecossistema, segundo Houaiss (2004), é um conjunto de relações entre as características físico-químicas dos seres vivos e o ambiente.

A partir dessas reflexões sobre a espacialidade, a moradia e o habitat; iniciouse a investigação das espacialidades das cápsulas japonesas, pois os autores acreditavam que eram exemplos de ambientes mínimos e que poderiam ter as qualidades necessárias para viver na cidade contemporânea.

Durante a pesquisa, verificou-se que as cápsulas eram espaços habitáveis e que estavam conectadas a um sistema urbano maior, a chamada Megaestrutura, como se pode ver nas propostas de Kenzo Tange para a Baía de Tokyo, ou nas Helix City de Kisho Kurokawa que serão descritas à frente. Devido a relação entre as cápsulas e as estruturas foi necessário para este trabalho olhar para as megaestruturas para compreender as relações entre ambas.

Nesta pesquisa notou-se também que a idéia de industrialização na construção civil estava estreitamente associada aos conceitos de cápsulas e megaestruruas, a publicação de artigos a respeito de montagem dos edifícios, organização das fábricas para construção de componentes, sistemas estruturais, entre outros era frequente em livros e revistas da época. 
Desse modo, a análise e compreensão das megaestruturas, das cápsulas e da industrialização na construção civil foram escolhidas como base para o entendimento de alguns princípios norteadores do habitat, com a premissa de que este é um lugar em que um organismo vive, o ambiente propício para o ser humano, entendido neste trabalho que este local é a cidade. As cápsulas, o abrigo ou a moradia serão tratados como espaço do habitar, compreendido como uma atividade, ou como um objeto que configura um envoltório, ou um invólucro.

A escolha temporal de 1960 aconteceu em primeira instância por se tratar da época em que as megaestruturas e cápsulas foram elaboradas. Posteriormente, verificou-se que essas propostas de habitat eram decorrentes de vários eventos que modificaram a vida do homem e da sociedade, entre as décadas de 1950 e 1970 e que serão desenvolvidos no trabalho.

Nesse período de 1950 e 1970, houve a incorporação da publicidade como instrumento de disseminação dos modos de vida, a elaboração das Teorias Geral de Sistemas ${ }^{8}$, a aplicação da Cibemética ${ }^{9}$ e Teoria da Complexidade ${ }^{10} \mathrm{em}$ arquitetura e urbanismo; a modificação do mercado de produtos para o mercado de serviços (SEVCENKO, 2001), elevados investimentos nos ramos da ciência e tecnologia, as contestações culturais, entre vários outros aspectos.

Em decorrência desses acontecimentos, considerou-se fundamental compreender o contexto histórico em que as propostas foram elaboradas, buscando conhecimento sobre as teorias que eram recorrentes nas falas dos arquitetos e sobre acontecimentos da época, incluindo os processos de comunicação, que foram determinantes para a formação da sociedade de 1960.

8 Segundo Bertalanffy, a Teoria de sistema consiste em um "complexo de elementos em interação" (BERTALANFFY, 1975, p. 84).

9 De acordo com Von-Foster (2007), a cibernética foi definida por Norbert Wiener como "a ciência do controle e comunicação no animal e na máquina" (VON FOERSTER, 2007).

10 Edgar Morin foi um dos pensadores da Teoria da Complexidade, nela reunia a Teoria Geral de Sistemas, a Cibernética e a Teoria Matemática da Comunicação (MORIN, 1977). 
Verificou-se que as Teorias Sistêmicas, (Teoria Geral de Sistemas, Cibernética e Teoria Matemática da Comunicação), provavelmente constituiram o pano de fundo que subsidiaram a elaboração de várias teorias desenvolvidas pelos arquitetos analisados. Por essa razão, no decorrer desta dissertação houve a tentativa de avaliar o material publicado sobre as temáticas Megaestruturas, Cápsulas e Industrialização e a tentativa de identificar se estas tinham pontos comuns às Teorias Sistêmicas.

A partir dessa contextualização, observou-se que o J apão, país no qual o conceito de cápsulas parece ter sido melhor assimilado, sofria influência principalmente dos países ocidentais e, que os modos de vida tradicionais japoneses se alteravam desde a Revolução Meiji quando o J apão se abriu para buscar novos mercados comerciais. Surgiu assim a necessidade de conhecer a situação de alguns países como França, Itália e Inglaterra, que por muito tempo haviam influenciado culturalmente outros países como o J apão e Brasil.

A comparação com o território brasileiro ocorre devido a preocupação constante em se fazer uma reflexão sobre como as propostas emergentes eram recebidas pelos arquitetos brasileiros, já que vários intelectuais realizaram a formação no exterior e que as informações de um modo geral estavam cada vez mais disponíveis no mundo através dos meios de comunicação eletrônica. Por esse motivo considerou-se importante colocar exemplos desenvolvidos no Brasil nos dois primeiros capítulos e dedicando o terceiro inteiramente a ele.

No primeiro capítulo a escolha do arquiteto Yona Friedman se deu porque ele surgiu como um dos protagonistas de um conjunto de urbanistas que discutiam formas de criar novos ambientes para a moradia e para outros espaços necessários na cidade. Nos anos 1960 Friedman propunha a organização do espaço urbano através de megaestruturas espaciais, utilizadas para diferentes funções, sobrepostas à cidade existente. 
No segundo capítulo, a seleção por Kisho Kurokawa se deu por ele ter sido um dos principais integrantes do grupo Metabolista junto com Fumihiko Maki, Noboru Kawazoe entre outros. Nas pesquisas bibliográficas, ele parecia ter desenvolvido extenso material teórico e publicado sobre as cápsulas, além de ter executado vários exemplares. Kurokawa era um teórico e se preocupava com a cultura japonesa e a assimilação dos conceitos e modos de vida ocidentais. Para Kurokawa, as cápsulas eram uma extensão do homem e necessárias para o crescimento espiritual do ser humano.

No terceiro capítulo a opção por J oão Filgueiras Lima se deu por ele trabalhar com a pré-fabricação no Brasil desde o início de sua carreira em 1955. Lima entendia que esse processo de construção seriada era uma escolha pela racionalização da construção civil e consequente diminuição dos custos e manutenção da mão-deobra empregada. Acreditava na modificação do país, por uma sociedade mais justa, através da industrialização e da educação.

Dessa forma o habitat estaria configurado a partir do entendimento das esferas dos objetos: megaestruturas, cápsulas e industrialização; das territorritorialidades: pelos diferentes graus de influência, França, J apão e Brasil e; recortados em 1960: época de modificações e do surgimento de novos paradigmas. Como demonstra o diagrama a seguir.

Tem-se, portanto como objetivo geral:

Compreender alguns princípios norteadores do habitat na década de 1960 através da análise da cidade com as megaestruturas, utilizando como exemplo a produção de Yona Friedman, da análise do material teórico produzido por Kisho Kurokawa sobre as cápsulas e da análise de como esse habitat poderia ser produzido através da industrialização tendo como exemplo o arquiteto J oão Filgueiras Lima.

E como objetivos específicos: 


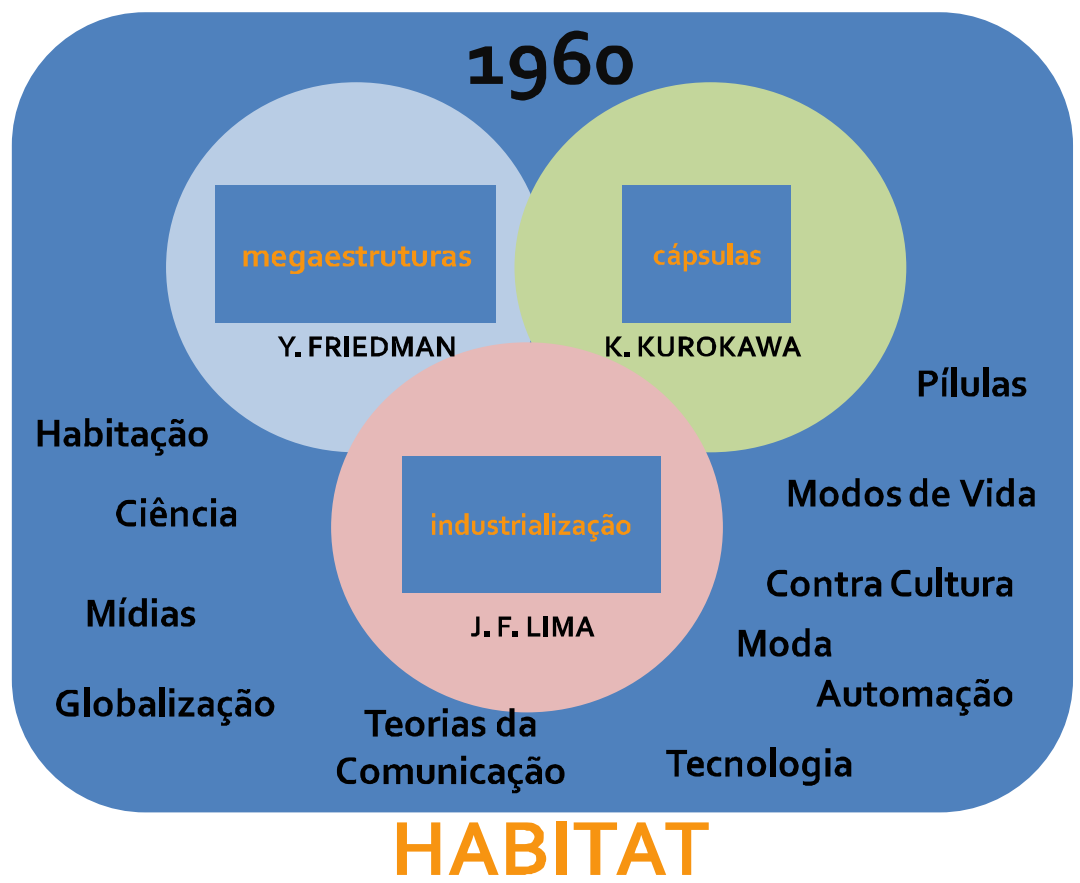

Figura 2: Habitat e seu contexto 
- Esclarecer as abordagens levantadas na pesquisa sobre cada objeto analisado: Megaestrutura, Cápsula e Industrialização;

- Contextualizar os territórios, França, J apão e Brasil na década de 1960

- Descrever sobre a formação e influências dos arquitetos

- Apresentar o conceito de habitat que representa a visão do grupo de trabalho e foi descrito por cada arquiteto;

- Descrever e analisar as teorias desenvolvidas pelos arquitetos;

- Realizar a análise comparativa das teorias desenvolvidas pelos arquitetos com as teorias cient́ficas da época: Teoria Geral de Sistemas e Teorias da Comunicação (Cibernética e Teoria Matemática da Informação).

- Buscar exemplos de trabalhos semelhantes às megaestruturas e às cápsulas no Brasil

De acordo com esses objetivos buscou-se bibliografias com o intuito de conhecer os diversos assuntos que se relacionavam com a pesquisa. Para a temática da sociedade da informação, fizeram parte da bibliografia, Hobsbawm (1995), Thompson (1999), Harvey (1989), Sevcenko (2001), Briggs \& Burke (2002), dentre outros.

Para o entendimento das teorias foram estudados textos de Bertalanffy (1975), Mulej (2004), Hofkirchner (2009), sobre a Teoria Geral de Sistemas. Wiener, (1954), Von Foerster (1974), François (1999), Scott (2004), Ashby (1960), Pask (1969), a respeito da Teoria Cibernética e, Shannon e Weaver (1949), autores da Teoria Matemática da Comunicação. McLuhan (200711) para entender a teoria da mídia eletrônica e Heisenberg (1996) sobre a Teoria da Incerteza.

E na arquitetura, fizeram parte Banham (1979, 2001), Frampton (1997), Whiteley (2002), Montaner (1995, 2008), Portoghesi, (2002), Ghirardo (2002), Choay (2000), 11 Copyright da primeira publicação, 1964. 
entre outros.

Para o entendimento da produção em arquitetura na década de 1960, foram consultadas as revistas Architectural Design, L'Architecture D'Aujourd'Huie Architectural Record do período de 1962 a 1979. Além desse levantamento, foi realizada uma busca no sistema WebWilson ${ }^{12}$ de base de dados de artigos.

Realizou-se a seleção de textos de autores-arquitetos da época que explicavam seus métodos, e o cruzamento com leituras de projetos, designe a leitura processual, com o intuito de verificar os conceitos nas diversas áreas do conhecimento.

Na pesquisa realizada sobre a produção arquitetônica do J a pão, consultaramse as revistas Shinkenchikue The Japan Architect de 1955 a 1979; e o acervo WebWilson. A revista Shinkenchiku (versão em inglês) foi publicada de 1955 a 1958 e depois mudou o nome para The Japan Architect. A partir das leituras, foi possível selecionar textos que abordavam os conceitos do grupo Metabolista, o contexto e desenvolvimento dos espaços de moradia e como as cápsulas estavam presentes na realidade dos arquitetos japoneses.

Dentre os periódicos brasileiros, foram pesquisados os exemplares da Revista Habitat: Arquitetura e Artes no Brasil, publicada desde 1950, editada em São Paulo. A revista apresentava artigos de arquitetura, mobiliário, patrimônio histórico, artigos de arquitetos estrangeiros europeus, americanos e japoneses, e artigos com artistas plásticos.

A revista Acrópole publicada de 1938 a 1971 era uma revista mensal impressa e editada em São Paulo. A publicação abordava preferencialmente assuntos relacionados a projetos de arquitetura, e estava focada na área de novas edificações. Raras vezes publicava artigos estrangeiros. E a revista Módulo foi

12 Base de dados eletrônico de artigos acadêmicos com consulta aberta para o sistema Dédalus da biblioteca da Universidade de São Paulo. 
utilizada em várias situações de busca direcionada por outras leituras de textos mais recentes.

Foi realizada entrevista com o arquiteto J oão Filguerias Lima em Salvador, no Instituto Brasileiro de Tecnologia do Habitat em julho de 2010 e uma uma visita ao Centro de Tecnologia da Rede Sarah (CTRS), nos reunimos com o arquiteto coordenador da siderurgia, que explicou todo processo desenvolvido na fábrica, desde a produção dos desenhos, desenvolvimento dos moldes, confecção das peças e encaminhamento para o canteiro de obras. Também foram levantados documentos no Centro de Planejamento (Ceplan) da Universidade de Brasília (UnB) e no Centro de Documentação (Cedoc) da UnB a respeito do processo contrutivo dos Alojamentos para Professores de Colina.

A partir do levantamento dos dados realizou-se a leitura, agrupamento, organização dos conteúdos levantados e a análise dos dados. A estruturação da dissertação foi organizada em três capítulos: Capítulo um: Megaestruturas, Capítulo dois: Cápsulas e Capítulo três: Industrialização. 


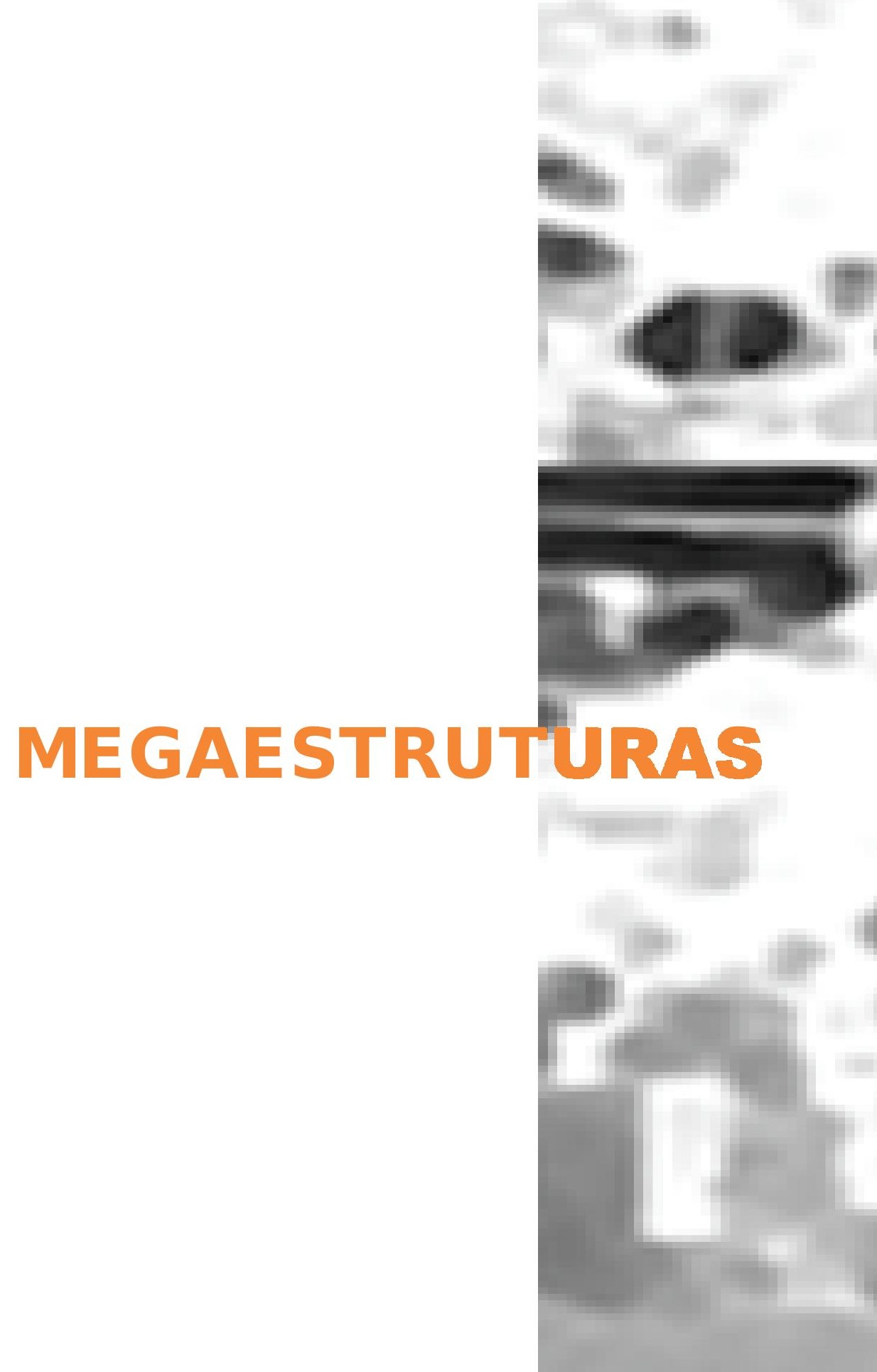



Esse capítulo tem como intuito compreender as Megaestruturas como modelo urbano, a partir do exemplo das produções do arquiteto franco-húngaro Yona Friedman. $\mathrm{O}$ aprofundamento da temática se deu através do entendimento de sua formação acadêmica, da análise de seus conceitos de habitat referentes à cidade, à moradia e, através da análise do processo de design que incluiu o planejamento, a produção, escolha e utilização dos elementos da casa.

As Megaestruturas foram abordadas por Banham (2001) em 1978 no livro Megaestruturas: futuro urbano do passado recente, e em diversos projetos que consideravam o tema. O projeto de Argel (1930), de Le Corbusier, foi citado por Banham como o precursor das megaestruturas, pois colocava toda a cidade em um edifício e, a definição previa grandes estruturas com funções de cidade, construídas com tecnologias emergentes e que acolhiam um alto contingente de pessoas em unidades habitacionais.

A exposição Megastructure Reloadedorganizada por Sabrina van der Ley e Markus Richter, em 2006, tinha como objetivo resgatar a história dos megaestruturalistas "tradicionais", Archigram, Yona Friedman e Constant, considerando que:

[...] os megaestruturalistas levaram as idéias do Team $X$ muito mais adiante, projetando visões urbanas caracterizadas pela mobilidade, flexibilidade e a participação dos habitantes. Com estes projetos que se tornaram os herdeiros finais de uma longa tradição de planejamento urbano idealista² (LEY \& RICHTER, 2006, tradução nossa).

O grupo Team $X$ que produziu o Manifesto Doorn ${ }^{3}$, propunha que a habitação fosse vista de forma integrada a um sistema urbano constituído por partes que se complementavam. O habitar estaria relacionado com a comunidade de que

\footnotetext{
1 Primeira edição 1978.

2 Original em inglês: [...] the megastructuralists took the Team $X$ ideas much further, designing urban visions characterized by mobility, flexibility and the participation of their inhabitants. With these designs they became the late heirs to a long tradition of idealist urban planning. (LEY \& RICHTER, 2006). 3 Ver anexo 1.
} 
fazia parte e com a circulação das pessoas na cidade 4 (SMITHSON \& SMITHSON, 2010). A habitação fazia parte desse sistema e não era um ambiente encarado isoladamente.

De acordo com Banham (2001), os anos 1960 foram de intensa atividade criativa sobre as megaestruturas, e o ano de 1964 significou um momento de muitos projetos e ideias sobre este assunto. Foi o ano em que Fumihiko Maki utilizou pela primeira vez o termo "megaestrutrura". Maki (19945), no artigo Notes on Collective Form, publicado na revista The Japan Architect, dizia que:

Os anos 1960 foram uma época em que o mundo arquitetônico ainda explorava vários assuntos da arquitetura moderna, que foram desenvolvidos e começaram a ser expressos antes da guerra. Ao mesmo tempo, dúvidas sobre a validade das ideias da arquitetura moderna no que diz respeito à cidade, e novas pesquisas foram iniciadas. A megaestrutura pode ser vista no contexto da época, como uma tentativa, baseada em uma fé na tecnologia, para expandir a margem de possibilidade arquitetônica ${ }^{6}$ (MAKI, 1994, p. 249, tradução nossa).

De acordo com Maki (1994), a preocupação dos arquitetos era solucionar os problemas de moradia decorrentes do aumento da população nas cidades. A sociedade urbana era caracterizada por 4 aspectos:

1. Coexistência e conflito de instituições e indivíduos incrivelmente heterogêneos;

2. Transformações rápidas e extensas sem precedentes na estrutura física da sociedade;

4 Documento escrito por Peter e Alison Smithsons.

5 O Texto Collective Form foi publicado pela primeira vez em 1964

6 Original em Inglês: The early 1960s were a time when the architectural world was still exploring various issues of modern architecture that had been developed before the war. At the same time, doubts were starting to be expressed about the validity of the ideas of modern architecture with respect to the city, and new investigations were being initiated. The megastructure can be seen in the context of the time as an attempt, based on a faith in technology, to expand the realm of architectural possibility. 
3. Métodos rápidos de comunicação, e

4. O progresso tecnológico e seu impacto se davam sobre as culturas regionais $^{7}$ (MAKI, 1994, p. 254, tradução nossa).

De acordo com Maki (1994), as megaestruturas eram '[...] esforços para encontrar formas mestras que satisfazem as demandas do crescimento e alterações urbanas contemporâneas $^{8 \prime \prime}$ (MAKI, 1994, p. 255, tradução nossa). E considerava que as megaestruturas apresentavam três problemas, tais como: 1 . A necessidade de cooperação entre várias disciplinas: estrutural, civil, climática, transportes, etc., caracterizadas por uma estrutura física e um mega ambiente construído. 2. As estruturas seriam construídas para um propósito ou função específicos e, 3. a infraestrutura seria um amplo investimento público.

De acordo com Banham (2001), Ralph Wilcoxon', em 1968, definia megaestrutura como:

- construída com unidades modulares;

- capaz de grande extensão ou mesmo "ilimitada";

- um quadro estrutural em que unidades estruturais menores (por exemplo, salas, casas ou pequenos edifícios de outros tipos) podem ser construídos, ou mesmo 'plugados' ou 'conectados', após ter sido préfabricados em outros lugares;

- um quadro estrutural com expectativa de ter uma vida útil muito mais longa do que as menores unidades podem suportar ${ }^{10}$ (WILCOXON

7 Original em inglês: _1. Coexistence and conflict of amazingly heterogeneous institutions and individuals; 2. Unprecedented rapid and extensive transformations in the physical structure of the society; 3. Rapid communications methods, and 4. Technological progress and its impact upon regional cultures. (MAKI, 1994, p. 254)

8 Original em inglês: [...] efforts toward finding master forms which satisfy the demands of contemporary urban growth and change. (MAKI, 1994, p. 255)

9 Arquiteto de projetos da Faculdade de Design Ambiental, Berkeley. (WILCOXON apud: BANHAM, 2001, p. 9)

10 Original em inglês: • constructed of modular units; • capable of great or even 'unlimited' extension; • a structural framework into which smaller structural units (for example, rooms, houses, or small buildings of other sorts) can be built, or even 'plugged-in' or 'clipped-on', after having been prefabricated elsewhere; • a structural framework expected to have a useful life much longer than that of the smaller units which it might 


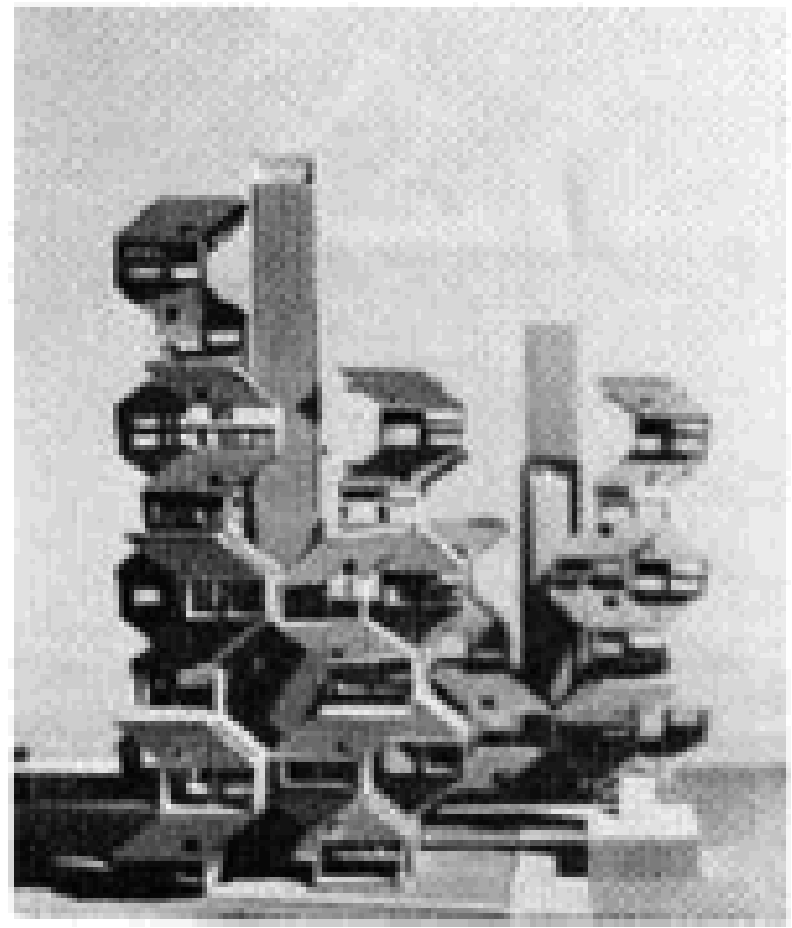

Figura 3: Segundo colocado:

Takefumi Aida and Itsuo Kamiya.

Maquete das habitações

modulares. Fonte: ( The Japan

Architect, n. 126, p. 42). 

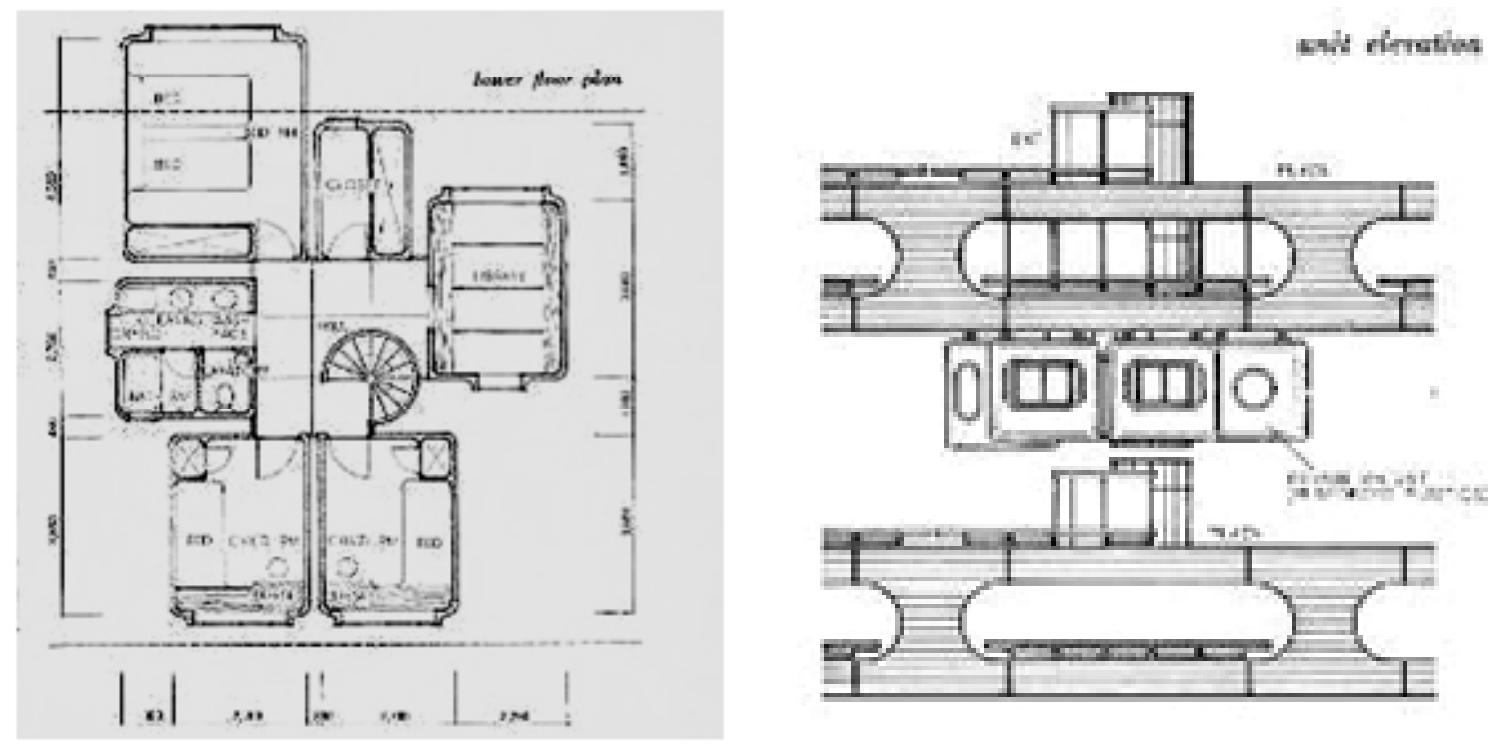

Figura 4: Primeiro colocado: Akira Shibuya. Vista da união entre Megaestruturas e planta do espaço do habitar. Fonte: (The Japan Architect, n. 126, p. 32). 
apud BANHAM, 2001, p. 9, tradução nossa).

As megaestruturas como descritas por Wilcoxon referiam-se àquelas estruturas que comportavam unidades de habitação individualizadas, que poderiam ser adequadas de acordo com a necessidade, como eram os casos dos exemplares produzidos no decorrer da década de 1960 em larga escala no J apão. Como mostram as figuras anteriores do Residential Design Competition de 1966 publicado na The Japan Architect ${ }^{\circ} .126$.

O entendimento de megaestrutura para Ley \& Richter (2006), organizadores da exposição Megastruture Reloaded, propunham que:

Fundamental para megaestrutura é a separação do 'hardware, o quadro de construção, incluindo toda a infraestrutura urbana, tais como fornecimento de energia, água e transportes, de 'software', que pode ser encaixado dentro ou fora da estrutura de apoio quando solicitado. A separação da estrutura de suporte de módulos individuais deve permitir à cidade adaptarse sem grande esforço aos desejos individuais de seus cidadãos, bem como para as condições sociais e econômicas em mudança. Arquitetura torna-se móvel, arquitetos podem abdicar em favor de cidadãos e, como é pedido por Yona Friedman, limitarem-se ao papel dos técnicos ${ }^{11}$ (LEY \& RICHTER, 2006, tadução nossa).

$\mathrm{O}$ arquiteto Yona Friedman escolhido como um dos representantes das megaestruturas foi mencionado por Banham (2001), no capítulo "Pioneiros e Iniciadores", junto com Louis Kahn no projeto para Filadélfia (1952), Kiyonori Kikutake projeto da Cidade Oceânica (1962), Kenzo Tange, projeto para Bahia de Tókio (1960), Lucio Costa no plano geral de Brasília (1956), Paul Maymont Projeto da llha Flutuante (1963) dentre outros. No capítulo, Banham tratava as

support. (WILCOXON apud BAN HAM, 2001, p.9)

11 Original em inglês: Fundamental to megastructure is the separation of 'hardware', the constructing framework including the whole urban infrastructure such as energy supply, water and transport, from 'software', which can be slotted in or out of the supporting structure as required. The separation of the supporting structure from individual modules should enable the city to adapt without huge effort to its citizens' individual wishes, as well as to the changing social and economic conditions. Architecture becomes mobile; architects can abdicate in favor of citizens and, as demanded by Yona Friedman, confine themselves to the role of technicians. (LEY \& RICHTER, 2006) 
megaestruturas como estruturas permanentes de grande porte, com unidades de habitação modulares e repetidas sob um plano informal e ampliável.

A partir desses conceitos, entende-se como Megaestruturas um ambiente edificado, viabilizado pelos avanços das tecnologias emergentes, a partir da década de 1950 e com dimensões capazes de abrigar um alto contingente populacional, superior a dez mil pessoas, acolhidas em unidades habitacionais que são acopladas à essas megaestruturas.

\subsection{Contextualização do Momento}

Harvey (1989) aponta que no final dos anos 1950 e 1960, as cidades foram cenário de várias transformações sociais. Era reconhecida como a era do consumo de massa, atraíam um elevado contingente populacional para as metrópoles, ocasionando alta demanda de habitações e de transportes públicos. O excesso de veículos resultava em grandes congestionamentos nas vias urbanas e a mobilidade era tema central nas discussões sobre o ambiente urbano.

E ainda segundo o autor, a década de 1960 representou um marco na transformação dos modos de vida da população. Percebidas, na modificação da noção de valor através da veiculação de mercadorias pelos meios de comunicação, pela apropriação da vida como efêmera, a habitação vista como um laboratório com eletrodomésticos, com a produção e consumo de alimentos em massa, pela disseminação dos alimentos industrializados como os junk e fast foods e pela valorização do corpo escultural, produzido artificialmente.

Textos de revistas do período analisado reforçam a visão das tecnologias na vida do homem e como estas poderiam ser utilizadas para o seu benefício. McHale (1967), falava que o homem tinha ampliado a sua capacidade orgânica através do controle e da automação de equipamentos. Desde simples mãos 
mecânicas, que aumentavam as possibilidades dos membros; até a conjugação de várias ferramentas e formas de energia, como por exemplo, as fábricas que representavam mecanismos complexos automatizados.

Nesse sentido, Gordon (1967), em um artigo sobre os efeitos da tecnologia no desenvolvimento do homem, advertia que:

[...] a simbiose atual entre o homem e a máquina pode progredir a ponto de interagir diretamente entre o cérebro e o computador, além disso, talvez exista a possibilidade de formação através da gravação de informações diretamente no cérebro ${ }^{12}$ (GORDON, 1967, p. 96, tradução nossa).

O autor ponderava ainda sobre alguns possíveis ramos de desenvolvimentos tecnológicos: 1. Materiais ultraleves à base de plástico ou metais para utilização em arquitetura; 2 . Previsões de tempo, facilitando o controle do ar e de poluições, promovendo a agricultura e prevendo possíveis catástrofes; 3 . Base de dados, com máquinas que poderiam armazenar uma quantidade indescritível de informações; 4. Dessalinização das águas do oceano, auxiliando no provimento de água para a população do globo; 5. Extração mineral oceânica; 6 . Agricultura no oceano; 7. dinheiro, através de cartões de crédito poderiam eliminar o dinheiro, transações de serviços poderiam ser acompanhadas através do computador criando contas de clientes; 8. Energia Termonuclear; 9. Controle Climático; 10. Controle Genético; 11. Controle de Fertilidade e; 12. Tripulação espacial em órbita. (GORDON, 1967) Algumas dessas proposições pareciam impensáveis, mas muitas atualmente fazem parte do nosso cotidiano.

$\mathrm{O}$ desenvolvimento tecnológico acontecia simultaneamente em várias áreas. $\mathrm{Na}$ saúde, as pesquisas descobriam a constituição do DNA (ácido desoxirribonucléico), elemento proteico que guarda as informações do ser humano. A agricultura 12 Original em inglês: [...] Actual symbiosis of man and machine may progress to the point of enabling man to extend his intelligent by direct interaction between his brain and the computer. Beyond this, there is perhaps the possibility of education by directly recording information on the brain. (GORDON, 1967, p. 96) 
aumentava a produção através da genética e das tecnologias aplicadas no campo. E dentre outros materiais introduzidos na época estavam o plástico, o náilon, o laser que podiam ser utilizados nos mais diferentes ramos do mercado de consumo.

Whiteley (2002), fala que Banham descreve que os anos seguintes ao Pós Guerra significaram a procura por uma "arquitetura da tecnologia" que refletisse as implicações que o corpo teórico e a tecnologia tiveram na arquitetura. $O$ efeito da tecnologização arquitetônica repercutia diretamente na escala doméstica, com a introdução de eletrodomésticos que estavam largamente disponíveis e consumíveis. Segundo Whiteley, Banham definia esse período como '[...] a idade da eletrônica doméstica e química sintética ”(BANHAM apud WHITELEY, 2002, p. 144).

Além do desenvolvimento tecnológico, está o desenvolvimento das mídias que influenciaram nas transformações da estrutura da sociedade e que ocorreram principalmente no contexto do ambiente doméstico. A lógica do consumo no cotidiano foi incrementada pelos objetos descartáveis e pela utilização da imagem simbólica associada à moda. O rápido aumento de população nas cidades, acoplado à individualização e à liberação sexual tornaram o ambiente da cidade o local propício para os modos de vida emergentes.

Hobsbawn (1995) assinalava algumas alterações que ocorreram na sociedade e que foram decorrentes das modificações do contexto da década de 1960. A participação ativa da mulher casada e independente provavelmente contribuiu para as modificações nas estatísticas. O divórcio aumentou no País de Gales e na Inglaterra, de um para cada cinquenta e oito casamentos em 1938, para um divórcio para 2,2 casamentos em 1980. Essa tendência se repetiu na Bélgica, França e Países Baixos. Da mesma forma, o desejo de ter filhos diminuiu por causa da participação da mulher no mercado de trabalho, à multiplicação das suas jornadas entre casa e profissão e ao investimento prioritário em sua realização pessoal.

Na França, de acordo com Forsé et. al. (1993), de 1960 a 1990, a população 
triplicou devido ao baby boom e a economia expandiu tendo como resultado o rápido enriquecimento dos franceses. Nesses anos a França também viveu um período de descrença nas instituições como o Exército, a igreja e as escolas. As modificações sociais também foram marcadas pelo aumento da instabilidade entre os casais, e as relações pessoais foram transformadas de autoritárias para relações de negociação e cooperação. De acordo com Michel Forsé, as mudanças da sociedade francesa, durante esses 30 anos caminharam em direção à "liberdade, igualdade e ao individualismo," diferente da "liberdade, igualdade e fraternidade" preconizada na Revolução Francesa.

De acordo com Hobsbawn (1995), o número de pessoas que viviam sozinhas aumentou, em diversas regiões do globo, uma tendência que se verificava desde a década de 1930 e que se intensificou a partir dos anos 1960. De acordo com o autor, em vinte anos (1960-80) a porcentagem de domicílios com apenas um morador quase duplicou nos Estados Unidos, de $12 \%$ para $22 \%$, sendo que em algumas cidades ocidentais chegava quase à metade de domicílios. Em consequência disso, associada aos outros fatores, o número de famílias nucleares diminuiu, como nos Estados Unidos: de 44\% das casas, em 1960, diminuiu para 29\% em 1980.

Além da mudança nos grupos familiares, eram evidentes as alterações comportamentais como a liberação sexual. Com a disseminação de novos métodos contraceptivos, as mulheres não se viam mais, necessariamente, destinadas ao casamento e à maternidade, a uma vida de cuidados com o lar e a família. Os homossexuais também tiveram uma maior visibilidade no plano social; apesar da grande discriminação, em 1961, Illinois foi o primeiro Estado americano a tornar a relação gaylegal (HOBSBAWM, 1995, p.318).

É nesse contexto que Friedman pensava e trabalhava, tanto que preocupava-se em responder às modificações da sociedade e dos modos de vida, vinculados às 
transformações tecnológicas e científicas da Segunda Revolução Industrial e que alterara essencialmente o cotidiano da vida doméstica.

\subsection{Sobre a vida de Yona Friedman}

O arquiteto Yona Friedman nasceu em Budapeste (Hungria) em 1923, estudou na Technical University, Budapeste, até 1945 quando teve que interromper seus estudos por causa do período de guerras. Após a Segunda Guerra Mundial, graduou-se pela Universidade de Technion em Haifa-Israel, local em que trabalhou como professor na área de habitação e como arquiteto até 1956.

Yona Friedman teve uma carreira diversificada como arquiteto, planejador, artista plástico e na produção e direção de filmes. Trabalhou com sua esposa Denise Charvein, que era cineasta. Friedman criou cerca de 15 filmes sobre lendas africanas e recebeu o Leão de Ouro de Veneza em 1962 com o filme "Aventures de samba gana, les"e "Origine des kabouloukou, I" (FRIEDMAN, 2006, p. 18).

Friedman elaborou, ao longo de sua vida vários manuais educativos sobre projetos para a concepção de edifícios, sobre técnicas para a sobrevivência da população mais pobre; manuais com procedimentos para encontrar água, noções de higiene, agricultura e economia de energia. llustrava suas ideias com desenhos esquemáticos em forma de histórias em quadrinhos.

Trabalhou para a UNESCO, ONU, para o Governo da Índia entre as décadas de 1960 e 1970, e distribuiu exemplares de manuais na América do Sul e na África. $\mathrm{Na}$ Conferência das Nações Unidas sobre Assentamentos Humanos, foi um dos responsáveis pela área de habitação e entendia que: '[...] a habitação não é só uma casa. Um telhado e alimentos não são elementos separáveis “13 (FRIEDMAN, 2006, p. 15, tradução nossa)

13 Original em inglês [...]"housing alone is not a house. A roof and food are not separable elements." (FRIEDMAN, 2006, p. 15) 


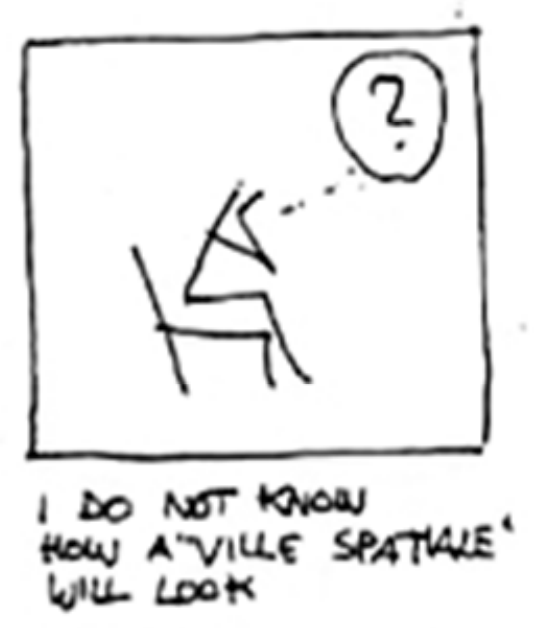

Figura 5: Exemplo de ilustração.

Fonte: (FRIEDMAN, 2006,

contracapa)

Esse formato de divulgação simples de suas informações, mostrado acima, era a maneira rápida que Friedman encontrou no decorrer de sua carreira como professor e palestrante. Como se refere a curadora Trisha Donnelly da exposição Yona Friedman Exhibition de 2008: 'O princípio orientador é que suas ideias sejam fáceis de manusear e permitem a aplicação criativa" ${ }^{14}$ (DON NELLY, 2008, tradução nossa).

A produção de Yona Friedman como arquiteto e urbanista concentrou-se em grande parte na elaboração de teorias e conceitos de ambientes urbanos. Entre suas obras estava o livro $A$ arquitetura móvel: rumo a uma cidade projetada por seus habitantes ${ }^{15}$ (1958), em que declarava os principais pressupostos do conceito de arquitetura móvel, concebida pelos seus moradores, ele dizia: "trata da

14 Original em inglês The guiding principle is that his ideas be easy to handle and enable creative application.

15 Original em francês: L'architecture móbile: vers une cité conçue par ses habitants 
possibilidade da auto-regulação no domínio da arquitetura" (FRIEDMAN, 1977, p. 57). Em Por uma Arquitetura Cientifica ${ }^{16}$ (1971), ele descreveu o processo de design e a participação de atores; em Utopias Realizáveis ${ }^{17}$ (1974) discutiu o papel dos governos e das mídias de massa, realizáveis somente em pequenas comunidades que ele denominou de grupo crítico. Outras publicações: $A$ arquitetura de sobrevivência: a filosofia da pobreza ${ }^{18}$ (1978), O vil para viver. Saber reter ${ }^{19}$ (1975) e, Comércio ou vila? ${ }^{20}$ (1977) (FRIEDMAN, 2006, p. 317).

Em Paris Espacial ${ }^{21}$ (fig 6) o arquiteto propôs uma estrutura espacial para a metrópole, em que aproveita espaços que poderiam ser utilizados para o habitar ou para outras funções.

Nova rota através de Medina22, Tunis (fig. 7), em uma visita a Tunis, Friedman fez um esboço de como ficaria a cidade e como resolveria alguns dos problemas da população mais pobre.

Na Proposta Relativa a Nova lorque ${ }^{23}$ (fig. 8), Friedman sugeriu que estruturas espaciais fossem colocadas em áreas sub utilizadas sobre as docas do Rio Hudson e do East River, sem alteração das funções. Sobre Manhatan, sugeriu uma estrutura ortogonal com oito ou nove camadas em espaços aéreos vazios.

No Guarda-chuva sobre Les Halles ${ }^{24}$ (fig. 9) Friedman trabalhou a ideia em meados de 1970 , e se concretizou em 2004. Ele procurava uma cobertura para a área do centro comercial.

16 Original em francês: Pour une architecture scientifique

17 Original em francês: Utopies réalizables

18 Original em francês: L'architecture de survie: une philosophie de La pauvreté

19 Original em francês: Des viles pour vivre. Saches La conserver

20 Original em francês: Oú commerce La ville?

21 Original em inglês: Paris Spatial

22 Original em ingles: New route trough the medina, Tunis

23 Original em inglês: A proposal concerning New York

24 Original em inglês: The "umbrella" of Les Halles 
Em Um museu que modifica a cada exposição ${ }^{25}($ fig. 10) Esse projeto foi elaborado para o concurso para o Centre Beaubourg (atual Center Pompidou), consistia em uma infra-estrutura na qual poderiam ser inseridos os componentes pelo público. Essa dinâmica poderia ser alterada a cada seis meses ou a cada nova exposição. Um edifício que se alteraria no mesmo ritmo de seus usos poderia ser uma inovação.

A proposta Tel-Aviv ponte da pazz (fig. 11) unia Israel e Gaza sobre o mar. Pensou em duplicar a costa com as Vilas Espaciais. Uma cidade linear sobre pilotis. As cidades sobre o mar eram melhores, po is conservam o mar intacto. Ele pensou nesse projeto como um elemento essencial para a paz, e por isso a denominou como a "Ponte da Paz"

Em Berlim ${ }^{27}$ (fig. 12), apesar de Friedman não ter conhecido profundamente a cidade e a cultura alemã, ele considerava que países que tinham passado por situações de reforma da cidade seriam oportunidades para adensar os territórios. A Alemanha, é um exemplo de situações e viveu dois episódios: o primeiro quando as cidades foram reformuladas no período de Haussman e o segundo pela guerra em 1945.

No projeto Monte Carlo 28 (fig 13), assim como o projeto de Nova lorque, Friedman utilizou o espaço sobre a água para colocar as estruturas que seriam utilizadas para habitação e comércio.

25 Original em ingles: $A$ museum which changes with everu new exhibiion

26 Original em inglês: Tel-Aviv Peace-bridge

27 Original em inglês: Berlim

28 Original em inglês: Monte Carlo 

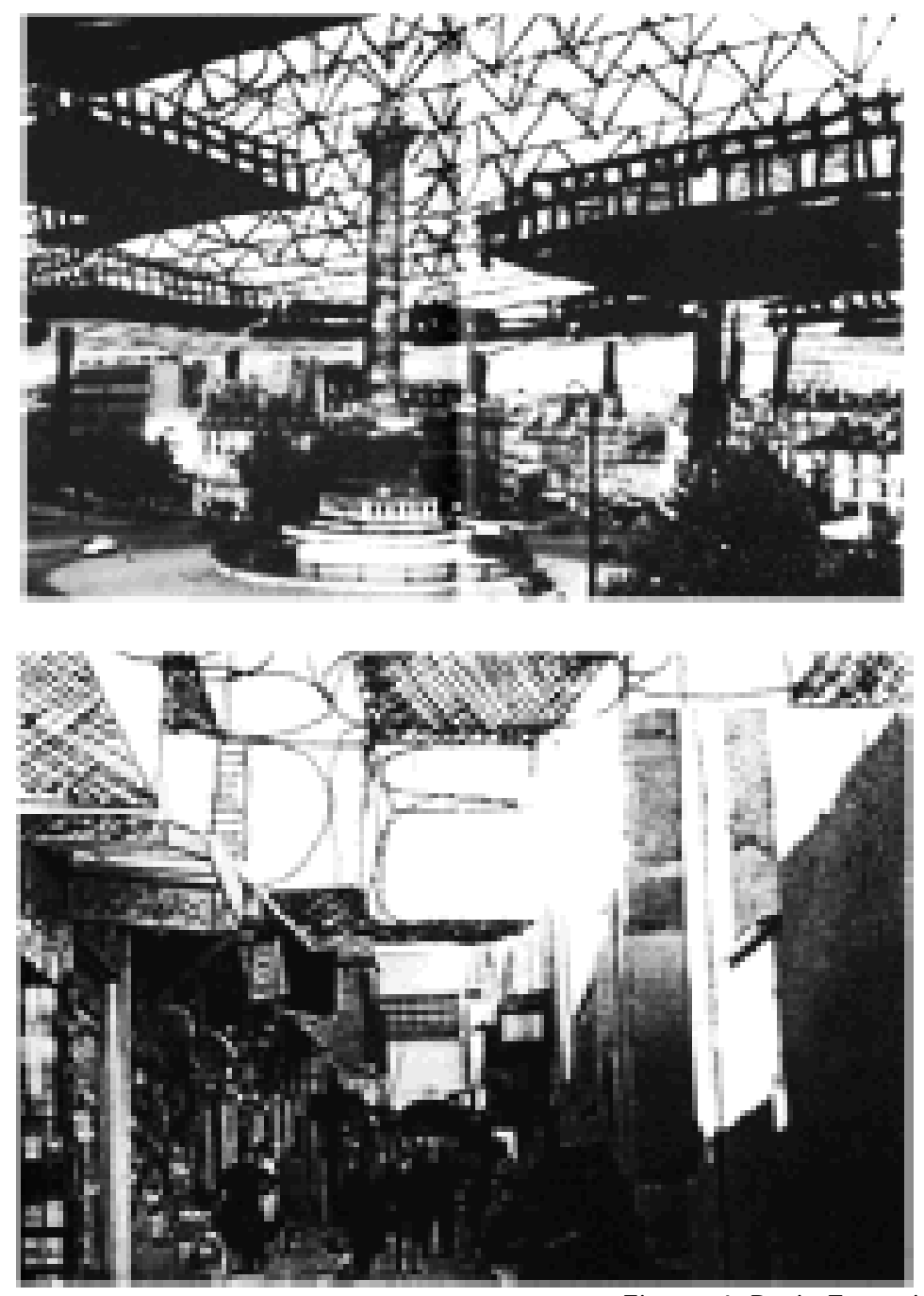

Figura 6: Paris Espacial (1959) Fonte: (FRIEDMAN, 2006, p. 312).

Figura 7: Nova rota através de Medina, Tunis (1959) Fonte: (FRIEDMAN, 2006, p. 299). 

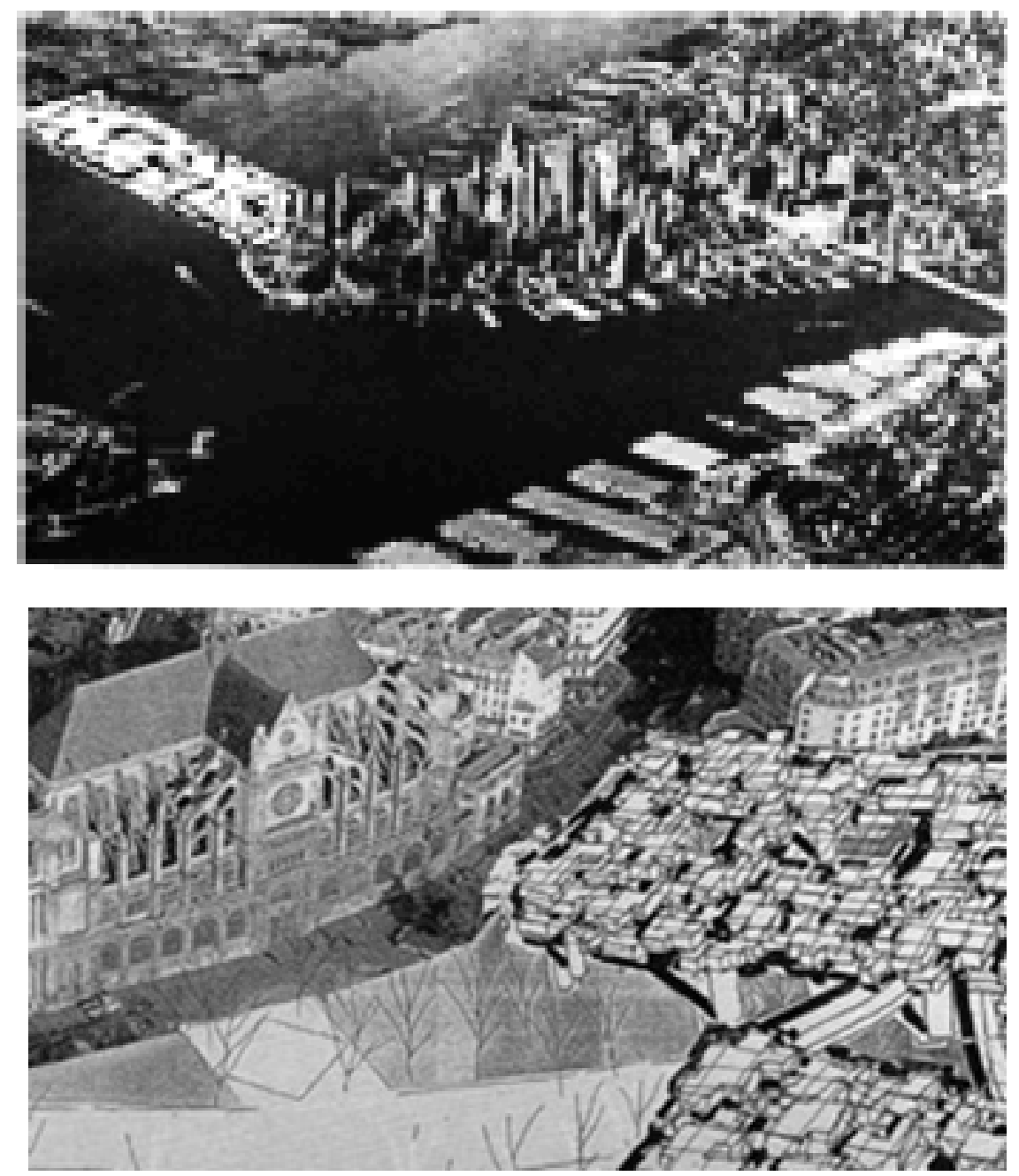

Figura 8: Uma proposta relativa a Nova I orque (1964) Fonte: (FRIEDMAN, 2006, p. 279).

Figura 9: O guarda-chuva sobre Les

Halles (1969). Fonte: (FRIEDMAN, 2006,

p. 287). 

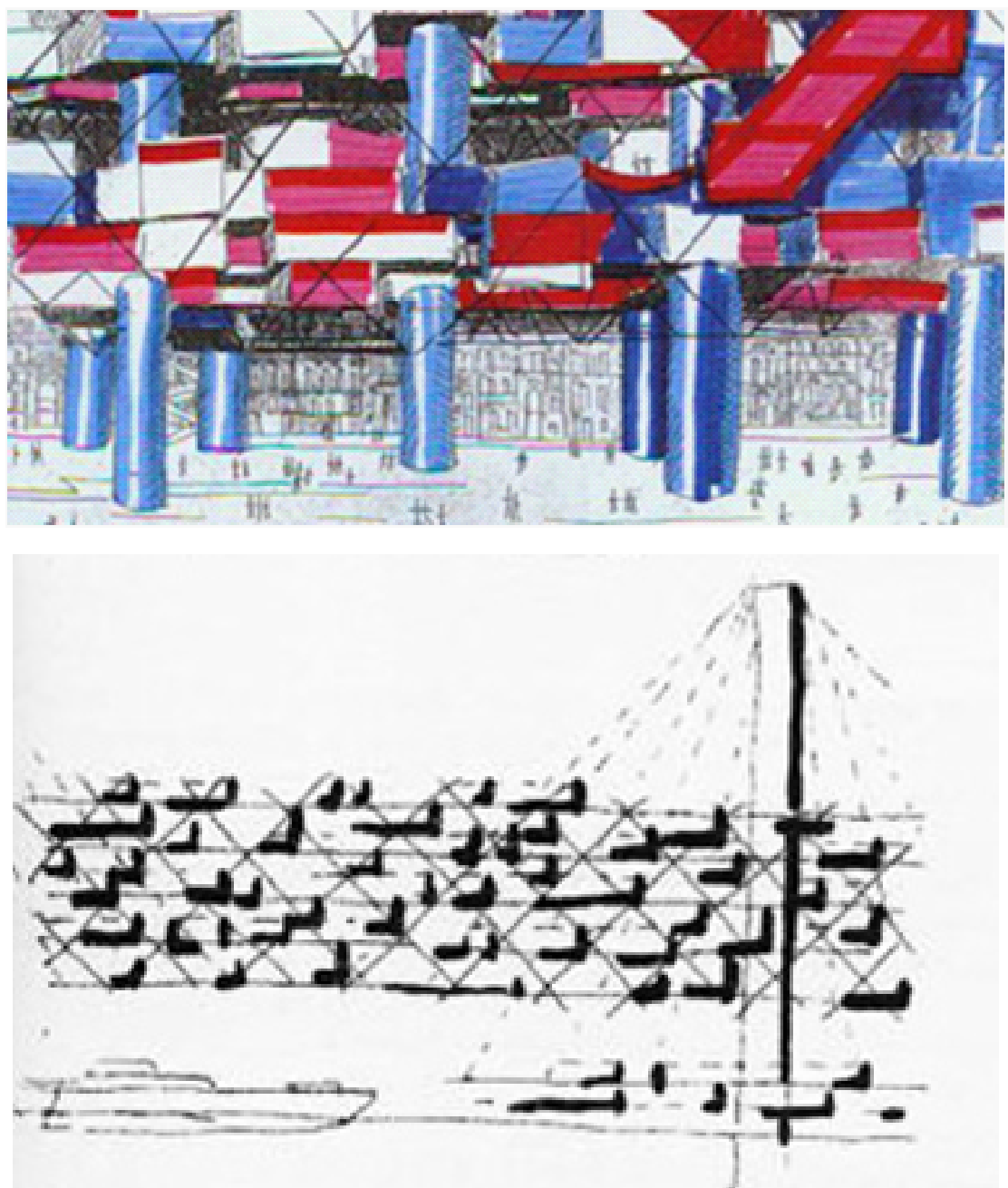

Figura 10: Um museu que modifica a cada exposição (1970) Fonte: (FRIEDMAN, 2006, p. 277).

Figura 11: Tel-Aviv ponte da paz (1990) Fonte: (FRIEDMAN, 2006, p. 283). 

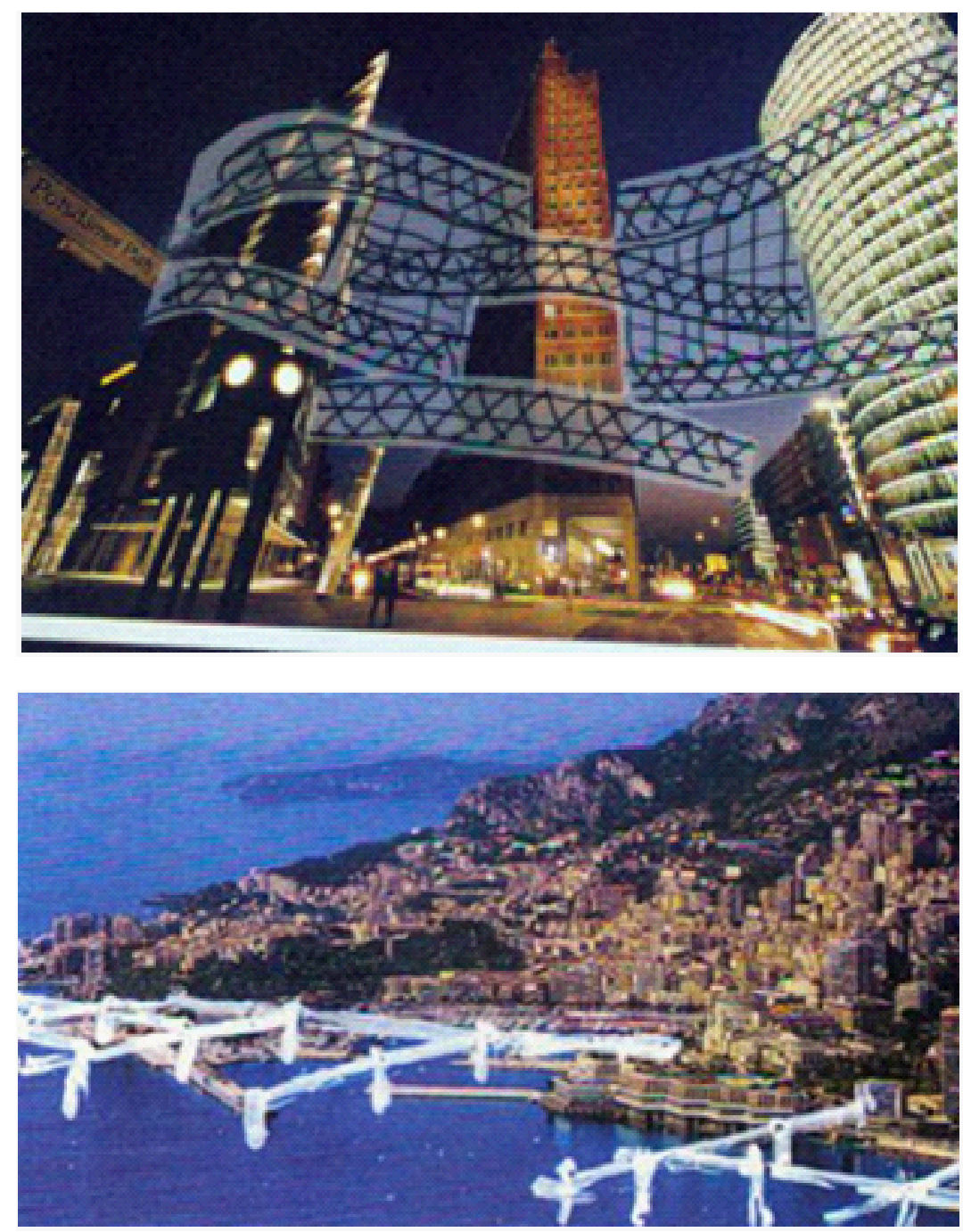

Figura 12: Berlim (2004) Fonte:

(FRIEDMAN, 2006, p. 29).

Figura 13: Monte Carlo (1980)

Fonte: (FRIEDMAN, 2006, p. 302). 
Em relação às influências profissionais de Friedman, de acordo com Banham (2001), J ohan Huizinga, autor do livro Homo Ludens, foi uma referência importante para o arquiteto. Friedman ainda mencionava que Werner Heisenberg, com o Princípio da Incerteza, contribuiu para a formação de suas proposições.

J ohan Huizinga (1872-1945) era de nacionalidade holandesa, historiador, autor de O outono da ldade Média (1919), Erasmus (1924) e, entre outros, Homo Ludens (1938). Foi editor da revista De Gids ${ }^{29}$. Huizinga era professor universitário, escreveu no livro O outono da ldade Média e entendia que "o conhecimento histórico é essencialmente estético, intuitivo e subjetivo" (Huizinga , 2000) . O livro Homo Ludens tratava sobre o jogo, e defendia que o instinto para o jogo era um elemento central da cultura humana,

[...] No jogo existe alguma coisa "em jogo" que transcende as necessidades imediatas da vida e confere um sentido à ação. Todo jogo significa alguma coisa. Não se explica nada chamando "instinto" ao princípio ativo que constitui a essência do jogo (HUIZINGA, 2000, p. $5)$.

Huizinga (2000) considerava que o jogo tinha como principais características, ser:

[...] uma atividade livre, conscientemente tomada como "não-séria" e exterior à vida habitual, mas ao mesmo tempo capaz de absorver o jogador de maneira intensa e total. É uma atividade desligada de todo e qualquer interesse material, com a qual não se pode obter qualquer lucro, praticada dentro de limites espaciais e temporais próprios, segundo uma certa ordem e certas regras. Promove a formação de grupos sociais com tendência a rodearem-se de segredo e a sublinharem sua diferença em relação ao resto do mundo por meio de disfarces ou outros meios semelhantes (HUIZINGA, 2000, p. 14).

A relação que Banham fazia entre Huizinga e Friedman estava em considerar que o planejamento sugerido por Friedman era espontâneo, os homens considerados

29 Revista holandesa de literatura geral existente desde 1837, também publica artigos de filosofia, sociologia, arte, política, ciência, história. 
livres e cada cidadão podia construir de acordo com sua iniciativa. Friedman elaborava regras claras para a ocupação das estruturas. Assim como a Teoria dos J ogos, a participação era livre, mas possuía regras e ordem claramente estabelecidas. Segundo Banham, apesar de Friedman não tê-la mencionado textualmente como uma de suas referências, a teoria teve prestígio nos círculos europeus da década de 1960.

De acordo com Banham (2001), para Friedman a mobilidade e a mudança eram elementos centrais, o pano de fundo era a democratização da cidade. As propostas de Friedman tratavam da modificação da cidade e das moradias. Banham criticou as soluções de Friedman como simplistas e não edificáveis.

Em relação à influência de Heisenberg, Yona Friedman considerava que o Princípio da Incerteza, desenvolvido pelo físico, se parecia ao que ele chamava de "princípio da individualidade", no qual defendia que os indivíduos se comportavam como partículas físicas ou sociológicas com leis abstratas de imprevisibilidade (ABRAHAMS \& FRIEDMAN, 2010) .

Werner Heisenberg foi considerado o criador da Mecânica Quântica em 1925. Publicou vários livros, entre eles; $A$ Parte e o Todo (1971), Os Princípios Físicos da Teoria dos Quanta (1930), A física dos núcleos Atômicos (1943) entre outros. A Incerteza da Teoria Quântica estava relacionada à posição e velocidade de um elétron em uma dada experiência, como descreve Heisemberg:

A tese filosófica de que todo conhecimento é essencialmente baseado na experiência conduziu por fim a um postulado que diz respeito à elucidação lógica de qualquer enunciado sobre a Natureza. Tal postulado poderia ser justificado nos tempos da física clássica, mas, desde o advento da teoria quântica, aprendemos que ele não pode ser satisfeito. Os termos "posição" e "velocidade de um elétron, por exemplo, pareciam outrora estar perfeitamente bem definidos tanto no que dizia respeito ao seu sentido como também em suas possíveis 
ligações com outro; e, de fato, eram conceitos claramente definidos dentro da estrutura matemática da mecânica newtoniana. Mas, do ponto de vista da mecânica quântica, viu-se que eles não estavam, de fato, bem definidos, como evidencia a correspondente relação de incerteza $[\ldots]{ }^{30}$ (HEISEMBERG, 1999, p. 121).

A assimilação da teoria de Heisenberg às atitudes do homem foi o alicerce para o desenvolvimento dos conceitos da Arquitetura Móvel, estudada pelo grupo de arquitetos que formavam o Grupo de Estudos de Architetura Móvel ${ }^{31}$ (GEAM) de que Yona Friedman fazia parte. O homem emergente, com características individualistas, independente e livre para ir e vir no espaço e tempo era o atorusuário que seria capaz de decidir sobre sua moradia e sobre a sua mobilidade.

Essas ideias seriam o foco das discussões de Friedman. No décimo Congresso Internacional de Arquitetura Moderna, o X CIAM em Dubrovnik, antiga Yugoslávia, em 1956, onde o tema central era o estudo do habitat humano, Friedman teve a oportunidade de apresentar pela primeira vez sua proposta de Arquitetura Móvel. $\mathrm{Na}$ entrevista concedida ao Mori Art Museum, ele a definiu como:

[...] arquitetura que engloba as mudanças em curso necessárias para fornecer "mobilidade social" com base em habitações e planejamento urbano que possam ser compostos e re-compostos, em função das intenções dos seus ocupantes e moradores ${ }^{32}$ (BRAYER, 2010, tradução nossa).

30 Primeira edição 1958.

31 Original em francês: Croupe d'Etudes d'Architecture Mobile

32 Original em inglês: [...] architecture encompassing the on-going changes required to provide "social mobility", based on dwellings and town-planning provisions that could be composed and re-composed, depending on the intentions of the occupants and residents". (BRAYER, 2010) 
Em 1958 Friedman organizou o GEAM juntamente com Paul Maymont ${ }^{33}$, Frei Otto ${ }^{34}$, J ean-Pierre Pecquet ${ }^{35}$, J erzy Soltan ${ }^{36}$, Eckard Schultze-Fielitz ${ }^{37}$, Werner Ruhnau ${ }^{38}$, David Georges Emmerich ${ }^{39}$, entre outros (BUSBEA, 2007, P. 62). Esses arquitetos tinham, em comum, a idealização de diferentes megaestruturas, possivelmente associadas às discussões desenvolvidas pelo grupo de estudo e com a influência de outros pensadores como Constant Nieuwenhuys ${ }^{40}$. Como mostram as figuras a seguir:

\section{Os projetos de vilas espaciais, vilas flutuantes e vilas subterrâneas de Paul Maymont} (fig. 14) eram megaestruturas com o centro livre que criavam uma área para o

33 Arquiteto e Urbanista francês, graduado pela Ecole des Beaux-Arts, Paris, e em 1959, fez estágio em Kyoto-Japan, local onde esteve em contato direto com os Metabolistas. Estudou possibilidades em megaestruturas flutuantes e subaquáticas. idealizador da Ville Flottante, Disponível em: <www.answers. com/topic/paul-maymont-2>. Acesso em 16 abr 10. Imagem: Fonte: Disponível em: \ttp://utopies. skynetblogs.be/post/6603478/ paul-maymont>, Acesso em: 23 mai 2010.

34 Arquiteto e engenheiro estrutural alemão, , reconhecido pelo seus trabalhos em estruturas leves, tensionadas e infláveis. Participou da Expo 67, Disponível em <www.freiotto.com/FreiOtto\%20ordner/ FreiOtto/HauptseiteGross.html>. Acesso em 16 abr 2010. Imagem Fonte: Disponível em:<http://www. freiotto.com/FreiOtto\%20ordner/FreiOtto/HauptseiteGross.html>, acesso em: 23 mai 2010.

35 Jean-Pierre Pecquet Membro da Associação Profissional de Arquitetos (Architects' Professional

Association). Elaborou a "Cidade de Bois de Bologne (City of the Bois de Boulogne) estruturas de habitação se espalhando pela floresta. (FRIEDMAN, 2006, p. 14)

36 Arquiteto, urbanista e designer polonês, professor na Graduate School of Design (GSD) Disponível em: < www.thecrimson.com/article/2005/10/28/in-memoriam-jerzy-soltan-jerzy-soltan/ >. Acesso em 16 abr 2010. I magem: Fonte: Disponível em: \ttp://www .archpresspk.com/images/March\%2010/YMCA\% 20International\%20Camp\%20Site,\%20Pune.jpg >. Acesso em: 23 mai 2010

37 Trabalhou sobre as teorias das cidades espaciais para a teoria das estruturas universais. É autor da Bridgetown across the Channel, uma estrutura em vários níveis que combina rotas de trem e carros e zonas residenciais entre a França e Inglaterra. Uma megaestrutura no seguimento de cidades lineares. Disponível em: <www.megastructure-reloaded.org/schulze-fielitz>. Acesso em 16 abr 10. Imagem: Fonte: Disponível em: «www.megastructure-reloaded.org/schulze-fielitz/>, Acesso em: 23 mai 2010.

38 Arquiteto e urbanista alemão, considera que a construção seja vista como um processo em que todas as partes envolvidas devam desenvolver o design criativo. Disponível em: <www.ruhnau.info $>$. Acesso em 25 abr 2010. Imagem: Fonte: Disponível em: $\varangle$ www.gelsenkirchen.de/.../Programm_2010.as >p, Acesso em: 23 mai 2010.

39 Franco Húngaro, arquiteto, escultor,e autor. Disponível em: http://eng.archinform.net/arch/11385. htm>. Acesso em 25 abr 2010. Imagem: Fonte: Disponível em: «www.flickr.com/.../in/set-

72157600751435646/>, Acesso em: 23 mai 2010.

40 I magem: Fonte: Disponível em: «ttp://www .uni-weimar.de/projekte/isp-gjk/index.php? id=118>, Acesso em: 23 mai 2010. 

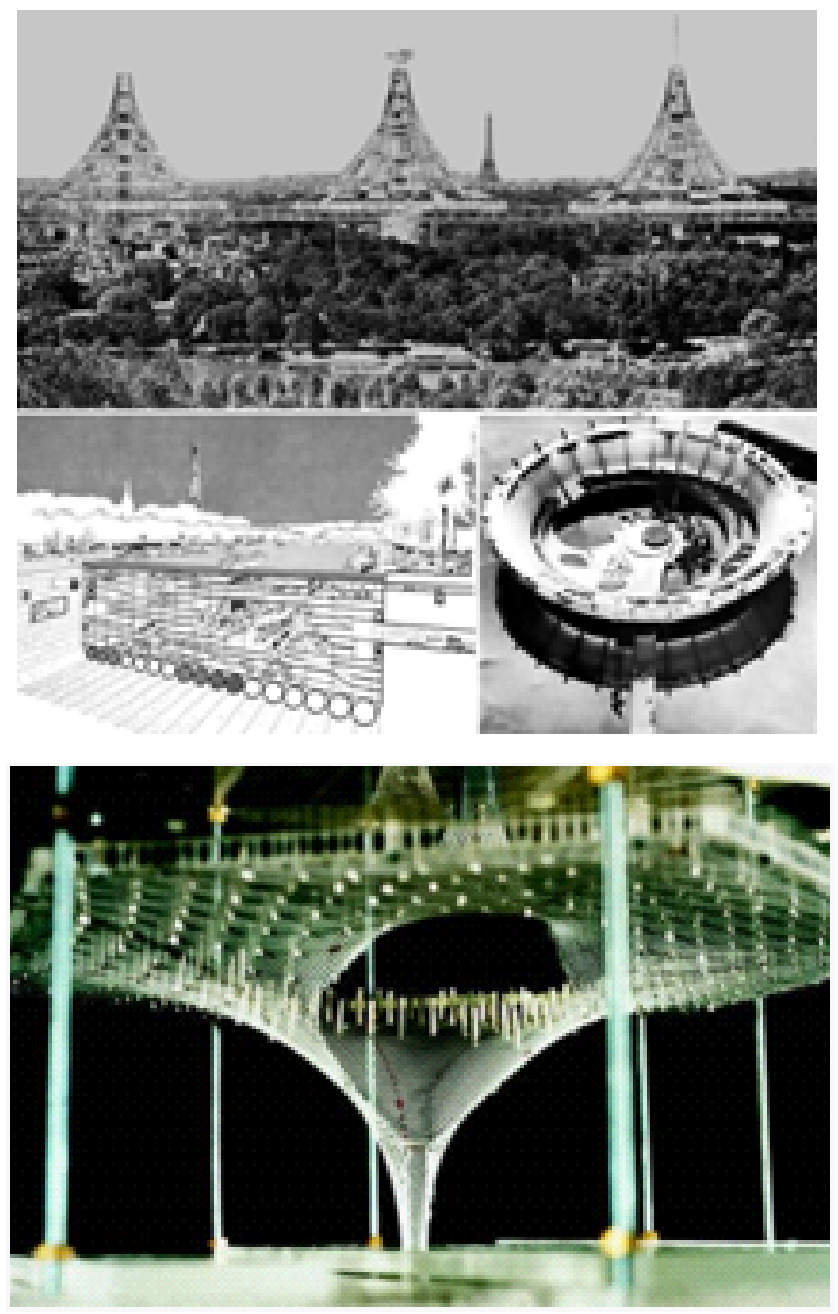

Figura 14: Paul Maymont - Projetos de vilas espaciais, vilas flutuantes e vilas subterrâneas.

Figura 15: Frei Otto: modelo suspenso para estação ferroviária de Stuttgart, Alemanha. 

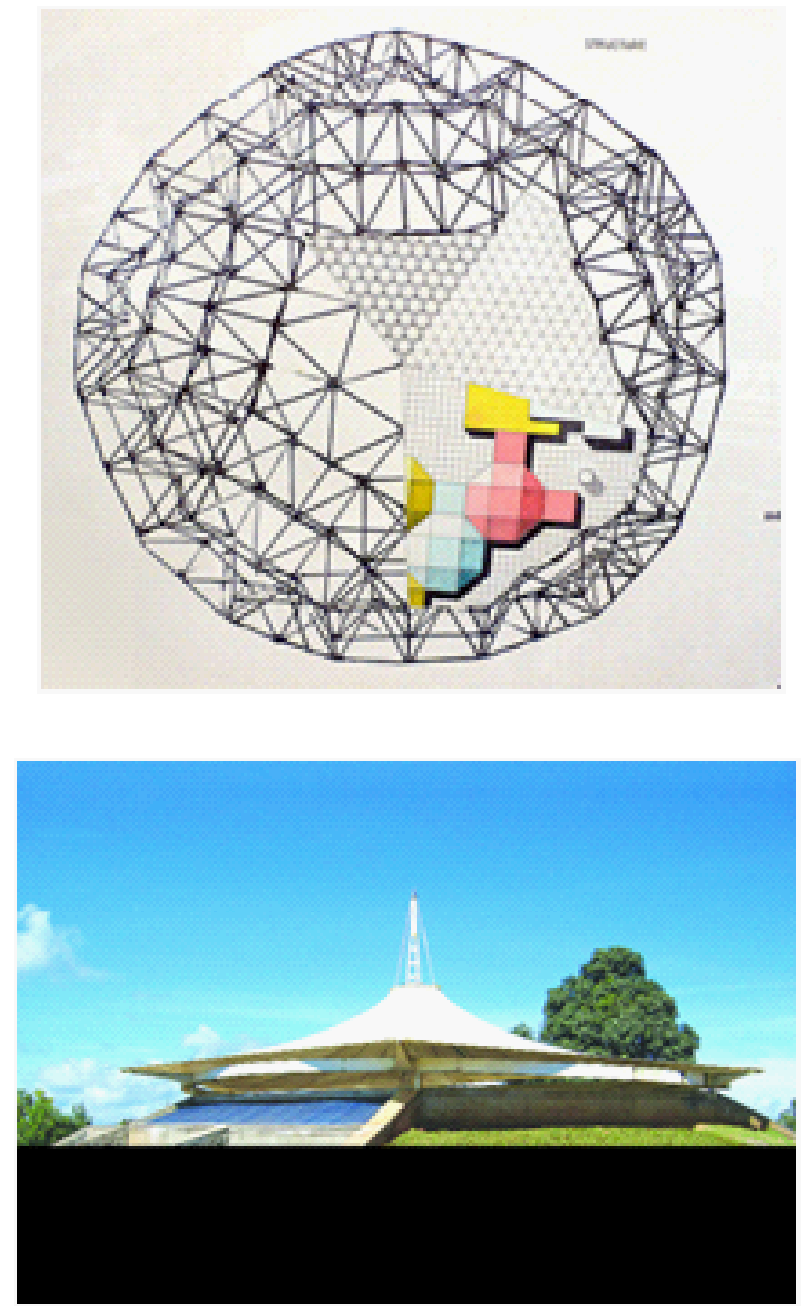

Figura 16: David Georges Emmerich Future City Experiment and Utopia in Architecture 19562006.

Figura 17: J erzy Soltan YMCA International Camp Site, Pune. 

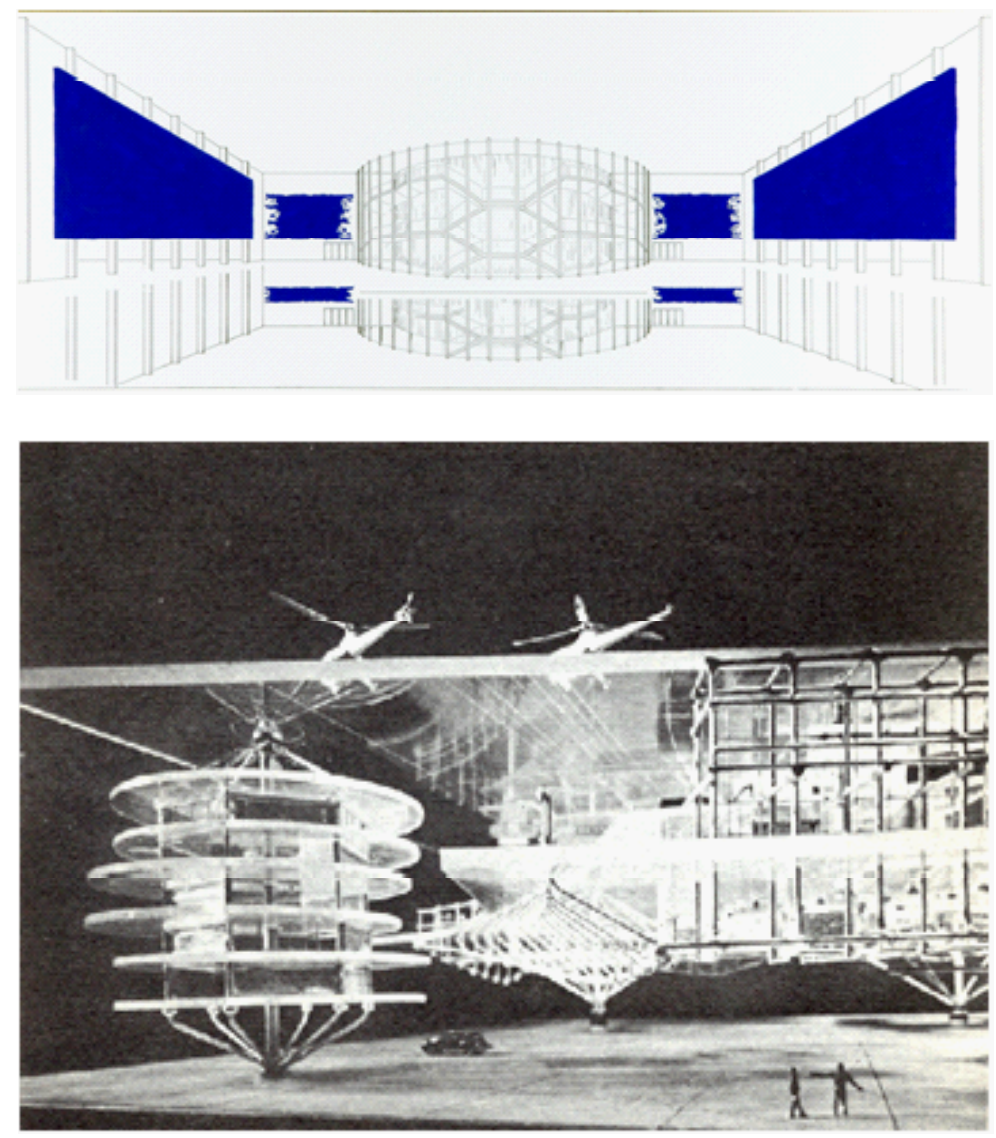

Figura 18: Werner Ruhnau - Museu de Arte de Gelsenkirchen. "As artes plásticas e eventos de teatro musical em Gelsenkirchen".

Figura 19: Constant - New Babilon é uma cidade flutuante sobre uma estrutura existente. 


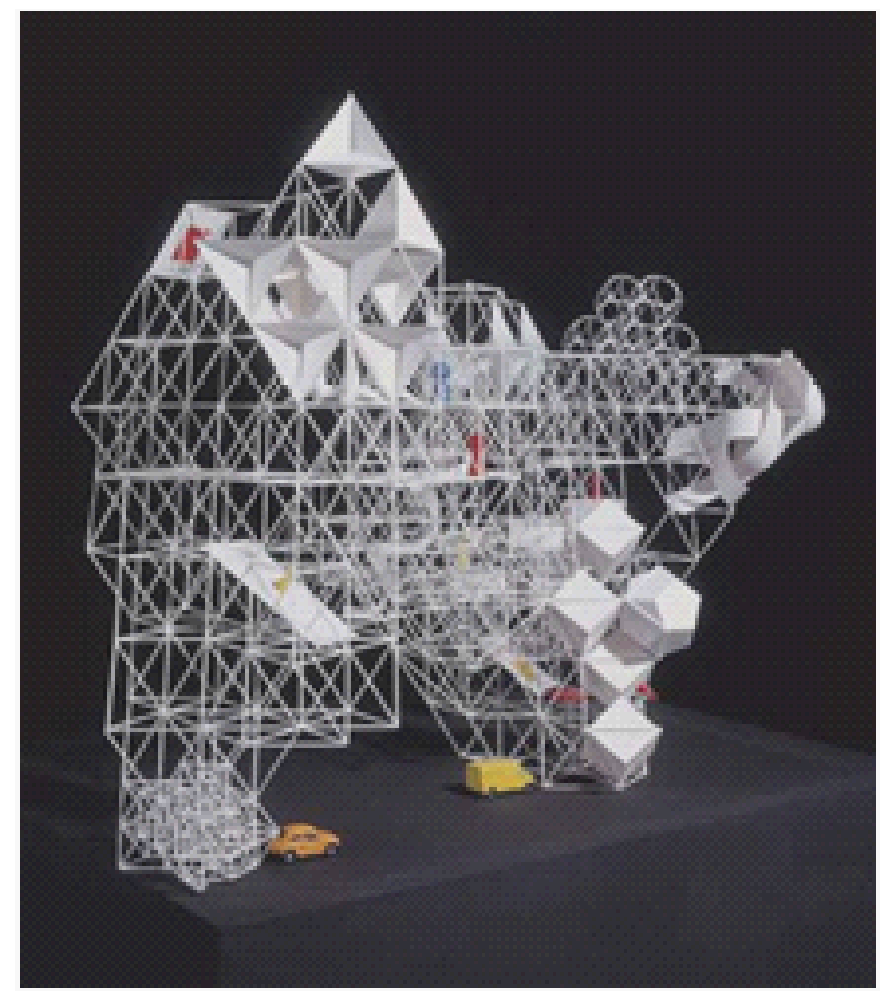

Figura 20: Eckhard Schulze-Fielitz, Raumstadt, 1959. $700 \times 700 \times 1350 \mathrm{~mm}$. Collection FRAC Centre, France. Photo: Philippe Magnon. 
uso coletivo. O modelo de Frei Otto (fig. 15) para estação ferroviária de Stuttgart, Alemanha, tinha a proposta de ser suspensa. Na figura 16 de David Georges Emmerich, pode-se verificar uma experiência para uma cidade utópica do futuro 1956-2006. Na fig. $17 \mathrm{~J}$ erzy Soltan YMCA International Camp Site, parece uma grande estrutura com vão livre interno. A figura 18 de Werner Ruhnau mostra um projeto para as artes plásticas e eventos de teatro musical em Gelsenkirchen. $O$ projeto de Constant (fig. 19) é uma cidade flutuante sobre uma estrutura existente, New Babilon. A figura 20 de Raumstadt, 1959 de Eckhard Schulze-Fielitz, nos mesmos moldes das estruturas desenvolvidas por Friedman, esse projeto utiliza o tetraedo como variação. Os projetos apresentam a similaridade de tratarem sobre megaestruturas, utilizam espaços sobre a água ou áreas ocupadas das cidades existentes.

Banham (2001) descreveu que o Urbanismo Espacial desenvolvido pelo grupo francês GEAM estava presente no livro de Michel Ragon Où vivrons-nous demain? (1963) e incluía a arquitetura experimental e visionária presente nas ideias que Banham chama de megapensamentos. Essa forma megaestrutural que previa a utilização espacial, era uma variação das propostas de Giedion (1943) elaboradas através de uma rede espacial com vários níveis de abastecimentos modificáveis na cidade. Banham descreveu:

[...] é a mais abstrata, menos material e mais convencionalmente "elegante" de todas as visões megaestruturais, e se chama espacial só porque acrescenta uma terceira dimensão, vertical, nas habituais duas dimensões da superfície plana do papel em que trabalha o planejador, para alcançar uma rede de planejamento tridimensional que libere o plano do solo ${ }^{41}$ (BANHAM, 2001, p. 58, tradução nossa).

41 Original em espanhol: [...] Es La más abstracta La menos material e La más convencionalmente "elegante" de todas lãs visiones megaestructurales, y se La llama spatial solo porque añade uma tercera dimensión, vertical, a lãs habituales dos dimensiones de La superficie plana del papel en que trabaja el planificador, para alcanzar una red de planificación tridimensional que libere al plano del suelo (BANHAM, 2001, p. 58). 
De acordo com Banham, as propostas do GEAM estavam predestinadas a fracassar por dois motivos: primeiro pela sua escolha datada da estética brutalista do concreto maciço e bruto. Segundo porque eram propostas tecnicamente impossíveis de serem construídas.

Larry Busbea, professor assistente do Departamento de História da Arte da Universidade do Arizona, em seu livro Topologies: The Urban Utopia in France, 1960-1970, de 2007, apontou que os trabalhos de Constant Nieuwenhuys, de New Babylon (1958-1967), que eram considerados um dos mais representativos como megaestruturas, apresentavam semelhanças com a espacialidade e a mobilidade dos projetos da Ville Spatiale do GEAM, mas apesar da participação informal de Constant nas reuniões do grupo, suas intenções eram divergentes na compatibilidade com o ordenamento do território, pois estava preocupado com as questões estruturais do espaço, segundo Simon Sadler:

[...] Constant procurava mais do que uma "reavaliação estrutural da cidade existente" e fazendo assim criou uma visão "utópica mais radical" do que as cidades vanguardas ${ }^{42}$ (Sadler, The Situacionist City apud BUSBEA, 2007, p. 72, tradução nossa).

O grupo GEAM preocupava-se com uma estrutura que possibilitasse a mobilidade da estrutura, do edifício e do usuário. Tinha como pressuposto básico a participação ativa do usuário e a mobilidade como princípio dessa sociedade.

Portanto, a megaestrutura era uma proposta para respaldar o conceito de mobilidade. Segundo Friedman, arquitetos como os do Grupo Shulze-Fielit ${ }^{43}$, David Georges Emmerich ${ }^{44}$, o inglês Cedric Price, Archigram e o grupo dos Metabolistas

42 Original em inglês: [...] “Constant sought more than a structural reevaluation of the existing city," and in doing so created a more "radically utopian" vision than those of contemporaneous avant-gardes. (Sadler, The Situacionist City apud BUSBEA, 2007, p. 72)

43 Arquiteto preocupado com megaestruturas, possuía escritório em Paris, projetou o Brückenstadt über den Ärmelkanal, uma estrutura de espaço multi-nível entre a França e a Inglaterra, com zonas residenciais. Disponível em: http://www.megastructure-reloaded.org/schulze-fielitz. Acesso em 26 abr 2010.

44 Arquiteto e Engenheiro, trabalhou com Robert Le Ricolais e Buckminster Fuller na morfologia estrutural da arquitetura. Criador do conceito de "Tensegridade" (tensão e contrabalanceamento a compressão entre si 56 
foram influenciados pelos conceitos da Arquitetura Móvel (FRIEDMAN, 2006, p. 30).

Friedman foi um arquiteto atento às questões sociais, teve uma carreira diversificada, atuava nas artes, educação, cinema e planejamento. Foi um teórico e trabalhava extensamente sobre os conceitos da Arquitetura Móvel com o GEAM. Foi influenciado por J ohan Huizinga, autor de Homo Ludens (1938), obra que descreve a Teoria dos J ogos, e por Werner Heisenberg, físico que trabalhou extensamente sobre a Mecânica Quântica (1927). Através desses dois teóricos, Friedman desenvolveu o método aplicado ao planejamento das megaestruturas e a elaboração da casa.

Dessa forma, o estudo sobre Yona Friedman foi fundamental por ele ser um importante teórico e arquiteto que trabalhou a temática do habitat como ambiente urbano, através do desenvolvimento das espacialidades nas Megaestruturas Espaciais e dos conceitos da Arquitetura Móvel, investigadas neste trabalho.

\subsection{Conceitos do Habitat}

A importância da análise do conceito das Megaestruturas Espaciais de Friedman, se deve ao fato dele ter desenvolvido literatura sobre esse objeto que era visto como uma maneira de compreender o espaço na escala da cidade e por serem vistos como um local propício para o ser humano viver em seu habitat

O habitat pensado por Friedman era constituído por 3 esferas: do espaço urbano, da casa e do indivíduo. Na Declaração ${ }^{45}$ do GEAM realizada em Paris, no ano de 1960, o grupo tratou alguns aspectos que considerava fundamentais para a adequação do espaço urbano à sociedade daquele momento. A declaração era dividida em quatro itens: 1. Edifícios inapropriados à demanda; 2 . Edifícios inapropriados às

para formar uma luz, estável de poliedros permanentes. Disponível em: www.editions-hyx.com/site/web/uk/ library/frac/fracl.html. Acesso em 26 abr 2010. 45 Publicada em anexo (BUSBEA, 2007, p. 63) 
necessidades familiares; 3 . Proposta de reforma para viabilizar a agilidade na troca dos edifícios e 4. Proposta para um espaço para viver.

O primeiro ítem dizia respeito à discordância das edificações em relação à vida cotidiana, à demanda populacional e à tecnologia daquele momento. $O$ segundo fazia uma reflexão sobre a adequação da circulação do espaço urbano e dos apartamentos em relação aos novos agrupamentos familiares.

Em relação ao terceiro, o grupo propôs algumas medidas para solucionar os problemas de troca de propriedade, de produção em larga escala e da participação dos moradores. Referiam-se à alteração das leis para possibilitar a troca ou modificação das construções, com a possibilidade dos moradores participarem da formação dos espaços de acordo com as necessidades individuais. E contavam com a industrialização para a diminuição dos custos e adensamento dos locais, que incluiriam os equipamentos urbanos e áreas de trabalho.

E no quarto ítem, o habitat era viabilizado pelo grupo GEAM através das seguintes premissas descritas abaixo:

Para realizar estas proposições, GEAM irá dedicar-se ao estudo das seguintes técnicas: 1 . Construção de elementos da habitação que são variáveis e intercambiáveis, incluindo a mobilidade das fachadas exteriores, paredes interiores, chão e teto. 2. A possibilidade de evolução das redes de abastecimento de energia, água e eliminação de resíduos. 3. O desenvolvimento de uma habitação de dimensão suficiente e significativa para as cidades que constituam em si mesmas: edifícios em forma de pontes; recipientes intercambiáveis [que] podem circular, voar, flutuar; edifícios flutuantes; climatização de grandes espaços ${ }^{46}$ (BUSBEA, 2007, p. 63, tradução nossa).

46 Original em inglês: To realize these propositions, GEAM will devote itself to study of the following techniques: 1. Construction of elements of habitation that are variable and interchangeable, including the mobility of exterior facades, interior walls, floors and ceiling. 2. The possibility of evolutivity of supply networks for energy, water, and waste disposal. 3. The development of unites d'habitation of sufficient size and significance to constitute cities in and of themselves: buildings in the form of bridges; interchangeable containers [that] can circulate, fly, float; floating buildings; climatization of large spaces. (BUSBEA, 2007, 
A Declaração do GEAM previa a construção de um habitat urbano através de megaestruturas e tinha o intuito de multiplicar o território da cidade, deixando-a mais densa. As cidades seriam construídas sem um pré-planejamento e responderiam unicamente à demanda espontânea dos usuários. Seria um espaço em permanente construção e modificação, adaptável, reconfigurável, transformável e móvel.

A Arquitetura Móvel tinha como base o comportamento imprevisível do ser humano. Entre os princípios da arquitetura móvel estava a proposta de um abrigo individual, que tocasse o mínimo do chão, que deveria ser desmontável e transformável espacialmente. Esses conceitos respeitavam, segundo Friedman, a liberdade do ser humano que, nesse sentido, era o seu direito natural.

O objetivo dessas propostas era compatibilizar as tecnologias aos novos modos de vida, tendo como instrumentos a comunicação e a produção industrial aplicados à habitação. O grupo considerava que as cidades e as habitações poderiam ser mais elásticas e móveis. Como Busbea comenta, "Seu objetivo era o de extrair o máximo de flexibilidade de uma estrutura mínima'47 (BUSBEA, 2007, p. 64, tradução nossa).

O conceito de mobilidade utilizado estava associado à condição do homem como indivíduo único, independente, autônomo e livre, capaz de estar em qualquer lugar, de acordo com a sua vontade. Era entendida pelo GEAM como;

Mobilidade: transformação na sociedade e na vida cotidiana é imprevisível, por um período comparável ao da existência do edifício em média. Novos edifícios e as cidades devem ser facilmente ajustáveis de acordo com a vontade da futura sociedade que irá utilizar: eles devem permitir todas as transformações, não precisando da demolição total ${ }^{48}$ (BUSBEA, 2007, p. 70, tradução nossa).

P. 63)

47 Original em inglês: His goal was o extract the maximum amount of flexibility from a minimal structure. (BUSBEA, 2009, p. 64)

48 Original em inglês: "Mobility: transformation in society and everyday life are unforeseeable for a period comparable to that of the existence of the average building. New buildings and cities must be 
As habitações seriam espaços montados de acordo com a necessidade dos seus usuários; plugadas às infraestruturas de fluxos como água, esgoto e tratamento de lixo. O importante não seria o resultado e sim o processo de construção e elaboração (FRIEDMAN, 1977).

A valorização do processo verificada nos membros do Grupo de Estudos de Arquitetura Móvel, certamente foi um reflexo das teorias desenvolvidas por Friedman. Nos seus vários livros publicados, ele descreveu a atuação dos arquitetos e urbanistas dentro do ciclo de produção, escolha e uso do habitat. Para estruturar o processo, Friedman se apoiou em teorias da Cibernética e na Teoria Matemática da Comunicação, como será comentado posteriormente.

\subsubsection{Espaço da Urbanidade}

O espaço do habitat era compreendido como o ambiente composto por diversas partes que compunham a cidade. A Declaração publicada pelo Grupo de Estudos da Arquitetura Móvel traçava algumas diretrizes que eram trabalhadas nos projetos propostos por Friedman.

Para Friedman, a cidade era palco de diversidade. Um ambiente que recebia diversos indivíduos que construiriam o espaço e a paisagem urbana. $\mathrm{E}$, acima de tudo era o lugar da transmissão de mensagens individuais ou coletivas, definitivas ou transitórias. Busbea fez a análise desse período afirmando que:

O espaço urbano passou a ser visto não como um recipiente neutro, mas como um meio condutor para a circulação e o intercâmbio de pessoas, informações e objetos ${ }^{49}$ (BUSBEA, 2007, p. 10, tradução nossa).

easily adjustable according to the will of the future society that will utilize them: they must allow all transformations, without requiring a total demolition." (BUSBEA, 2007, p. 70)

49 Original em inglês: "Urban space came to be seen not as a neutral container but as a conductive médium for the movement and exchanges of people, information and objects." (BUSBEA, 2007, p. 10) 


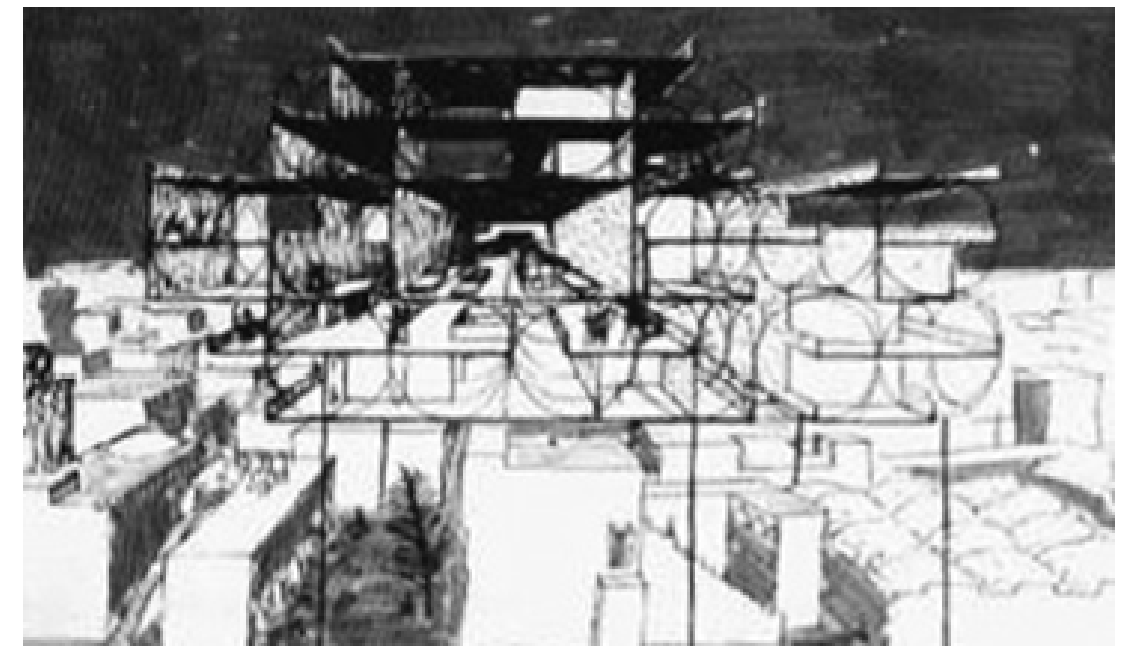

Figura 21: Yona Friedman, Spatial City, Tunis (1960). Courtesia Yona Friedman. Fonte: (BUSBEA, 2007, p. 66). 
Friedman considerava que os habitantes eram os responsáveis por inventar a cidade e, para que esse processo acontecesse, era necessário que o habitante acumulasse experiências de tentativa e erro a partir de suas decisões. Como ele acreditava:

Um arquiteto não "cria" uma cidade, é apenas um acúmulo de objetos. É o habitante que "inventa" a cidade: uma cidade desabitada, mesmo nova, é apenas uma "ruína" (FRIEDMAN, 2006, p. 3).

Choay (2000), no livro O Urbanismo, atestou que as cidades, pensadas após a Segunda Guerra Mundial, foram resultado das técnicas de construção existentes e do estilo de vida ou das necessidades próprias do homem moderno. Os sistemas construtivos utilizados eram estruturas complexas, suspensas, triangulares ou oblíquas autossustentáveis; em metais, membranas elásticas e plásticas ou folhas de concreto. As novas funções da cidade eram traduzidas por necessidades calculáveis, enaltecidas pelo aumento da população do globo e pelas necessidades emergentes frente ao progresso técnico, configuradas pela automação, mecanização do trabalho, dos transportes e das mudanças de ritmo cotidiano. CHOAY, 2000, p. 35).

Como descreve a crítica sobre as propostas de Friedman,

[...] A localização tridimensional de Friedman compõe-se de uma ossatura uniforme e contínua, semelhante a uma grade tridimensional de múltiplos andares, repousando a 15 metros acima do solo num sistema de estacaria (distantes de 40 a 60 metros): a ossatura indefinidamente prolongável, acima de qualquer tipo de terreno, incluindo-se cidades já existentes, é preenchida por elementos-padrões modulados, cuja inserção é móvel e totalmente suave [...] (CHOAY, 2000, p. 36).

A cidade espacial permitia uma alta densidade populacional, liberava a superfície terrestre e avançava sobre o mar, sobre o espaço aéreo ou pelo subsolo. Por isso 
motivo denominado de urbanismo espacial ou tridimensional. Choay (2000) ainda comentava que essas propostas de espacialização estavam associadas a produção de ambientes construídos e mecanicamente climatizados, levando o homem a uma vida cotidiana artificial.

Friedman publicou o conceito para a execução do planejamento das cidades espaciais e como seriam os comportamentos dos usuários que fariam parte desse espaço. A seguir, mostramos os dez princípios do planejamento da cidade móvel 50 desenvolvida por Friedman nas figuras a seguir.

1. O futuro das cidades: os centros de lazer. Outras funções são cada vez mais atomizadas.

2. A nova sociedade urbana tem de estar livre da influência do planejador urbano.

3. A agricultura nas cidades é uma necessidade social.

4. A cidade deve ser climaticamente condicionada.

5. Os prédios que formam a cidade devem obedecer a uma escala técnica.

6. A cidade deve ser a intensificação de uma cidade existente.

50 Original em inglês:

1. The future of cities: leisure centres. Other functions are increasingly atomized

2. The new urban society must be free from the influence of the urban planner

3. Agriculture in cities is a social need

4. The city must be climatically conditioned.

5. The buildings that form the city must comply to a technical scale

6. The new city must be the intensification of an existing city

7. The technique of three-dimensional urbanism also allows for the overlap or superposition of different neighborhoods

8. Buildings structures must be skeletons that can be filled at will

9. Cities with three million inhabitants are the empiric optimum model

10. The whole population of Europe in 120 cities of 3 million inhabitants 
7. A técnica de três dimensões no urbanismo permite a sobreposição ou superposição de diferentes bairros.

8. Estruturas de edifícios devem ser esqueletos que podem ser preenchidos à vontade.

9. Cidades com três milhões de habitantes são o modelo empírico ótimo.

10. Toda a população da Europa, em 120 cidades de 3 milhões de habitantes.

Ao idealizar o espaço urbano, o arquiteto e urbanista considerava que o lazer fazia parte do espaço da cidade, e que esta poderia ser utilizada a partir da sobreposição de espaços e funções. Por isso propôs uma megaestrutura que os habitantes pudessem ocupar. Esse espaço com acondicionamento climático teria uma população, que ele considerava adequada, de três milhões de habitantes e parâmetros mínimos de escala com, no máximo, dez metros de altura. A agricultura no espaço urbano deveria cumprir uma função social. Com essa conformação, as cidades espaciais poderiam ser implementadas na Europa de forma regular em cento e vinte locais de concentração urbana.

$\mathrm{Na}$ forma de pensar de Friedman, a distribuição espacial da população ocorreria essencialmente em centros urbanos com uma quantidade definida de população e área, embora ele afirmasse que a cidade tinha sua dinâmica própria e que poderia ser organizada e modificada de acordo com os usuários. Essa forma de planejamento colocada por ele demonstra uma postura absolutamente racionalizada, pensada no seu adensamento, distribuição, ocupação e uso, mostrando que existe uma organização definidas pelo arquiteto.

As Cidades Espaciais elaboradas por Friedman foram uma maneira que os arquitetos que faziam parte do GEAM vislumbravam para criar ambientes para 
adensar os espaços urbanos. Consideradas como Megaestruturas Espaciais, seriam o habitat propício para a troca de informação e ambiente para a participação e reinvenção da cidade.

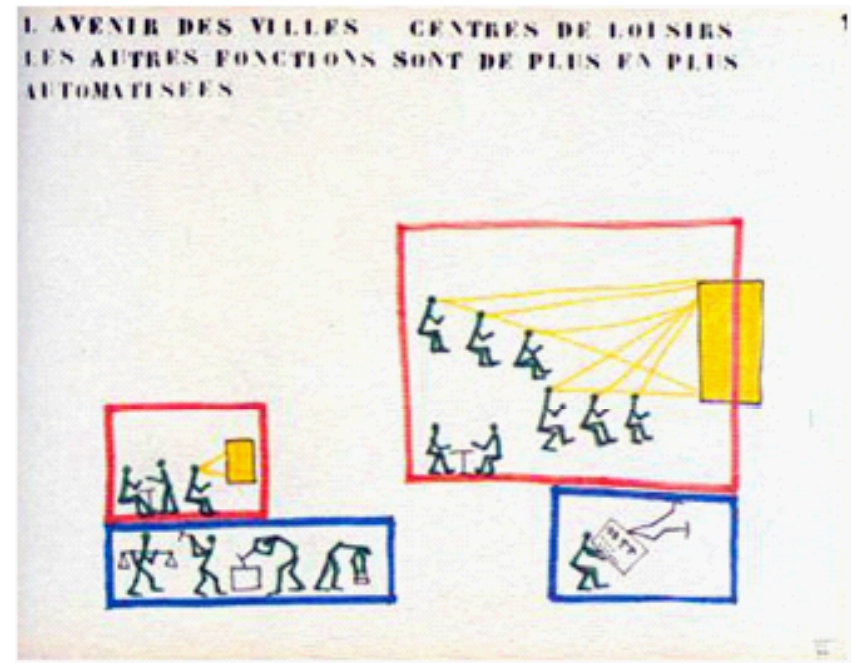

Figura 22: Princípio 1. Fonte: (FRIEDMAN, 2006, p. 65). 


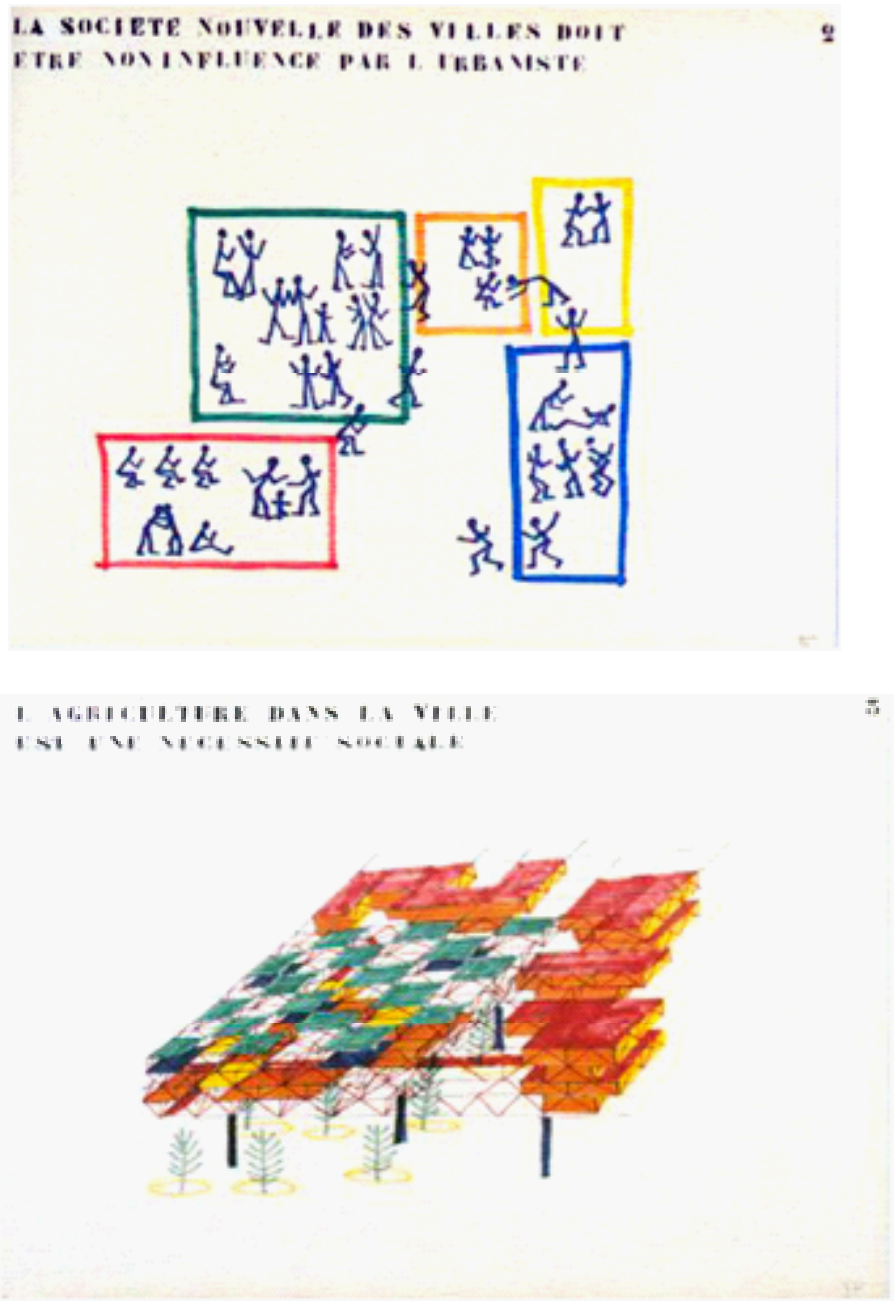

Figura 23: Princípio 2. Fonte: (FRIEDMAN, 2006, p. 65).

Figura 24: Principio 3. Fonte: (FRIEDMAN, 2006, p. 66). 


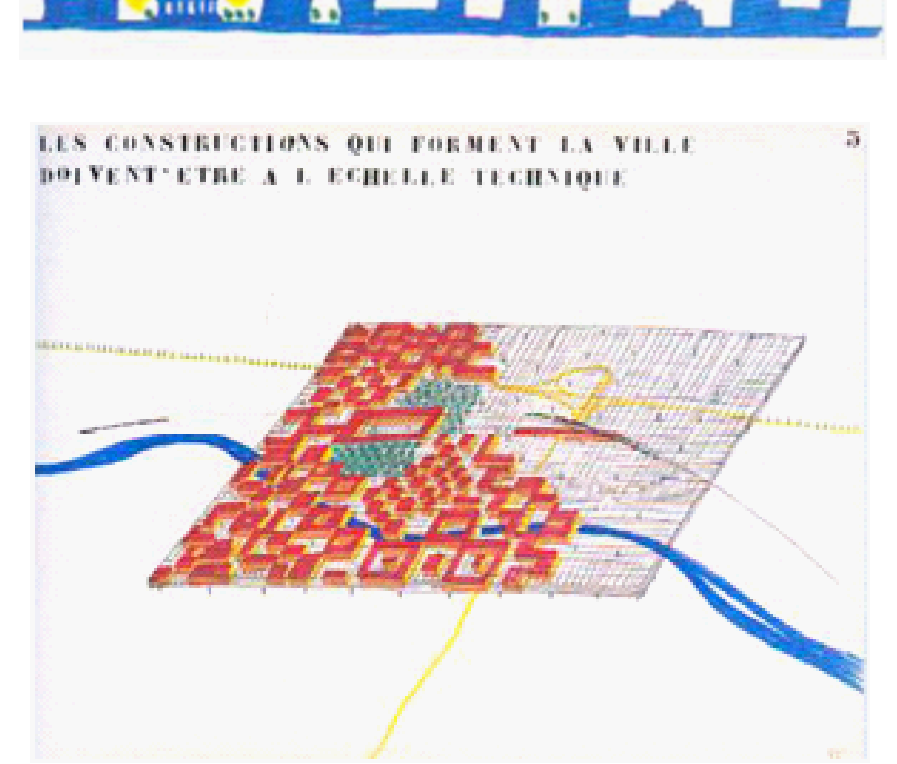




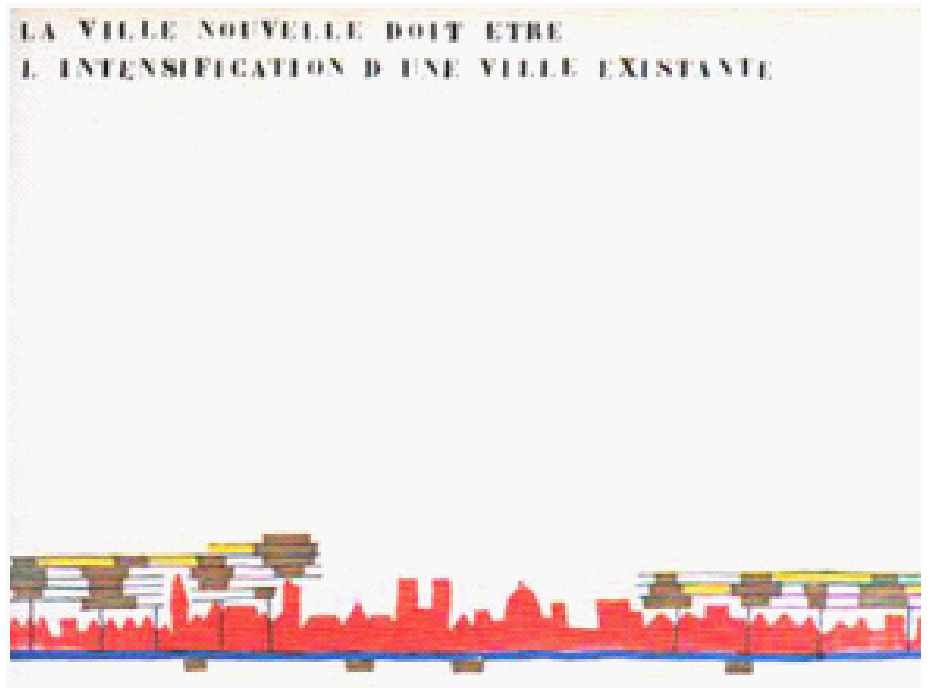

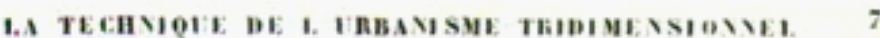
PEEMET EGAIEMENT I.A JIXT IPOSITION

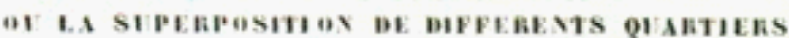

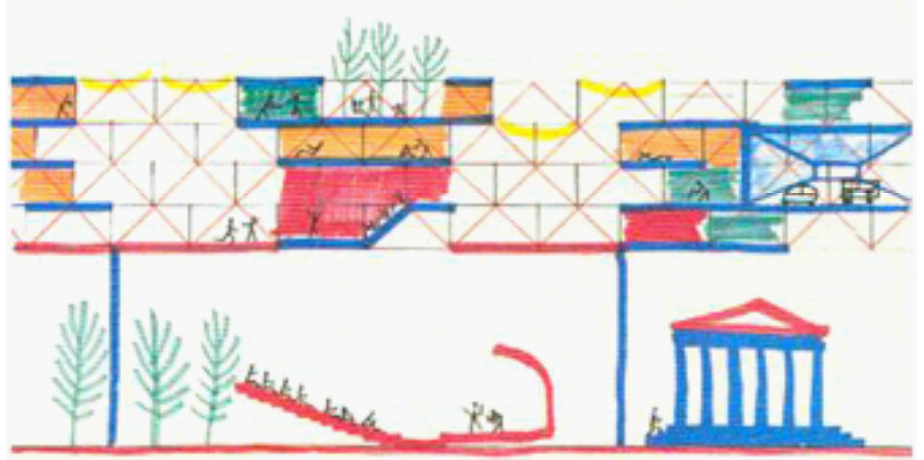

Figura 27: Princípio 6 Fonte:

(FRIEDMAN, 2006, p. 67).

Figura 28: Princípio 7. Fonte:

(FRIEDMAN, 2006, p. 68). 


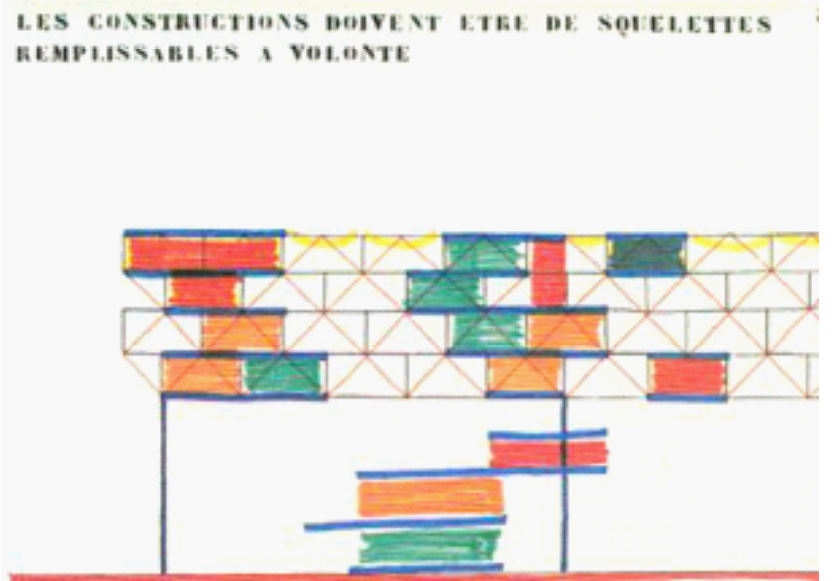

L.S VII.LS BE THOIS MIIIGNS D HaBITANTS EEPIESENTEN I. OPTIMIM EMPHEIOL

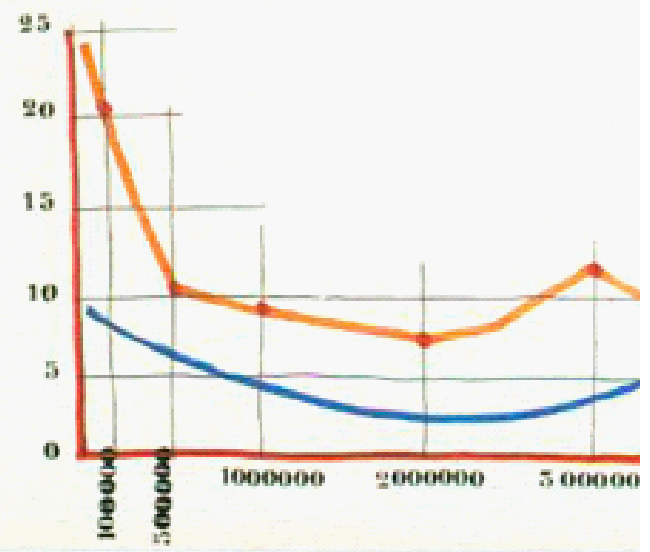

Figura 29: Princípio 8 Fonte: (FRIEDM AN, 2006, p. 68).

Figura 30: Princípio 9 Fonte: (FRIEDMAN, 2006, p. 69). 


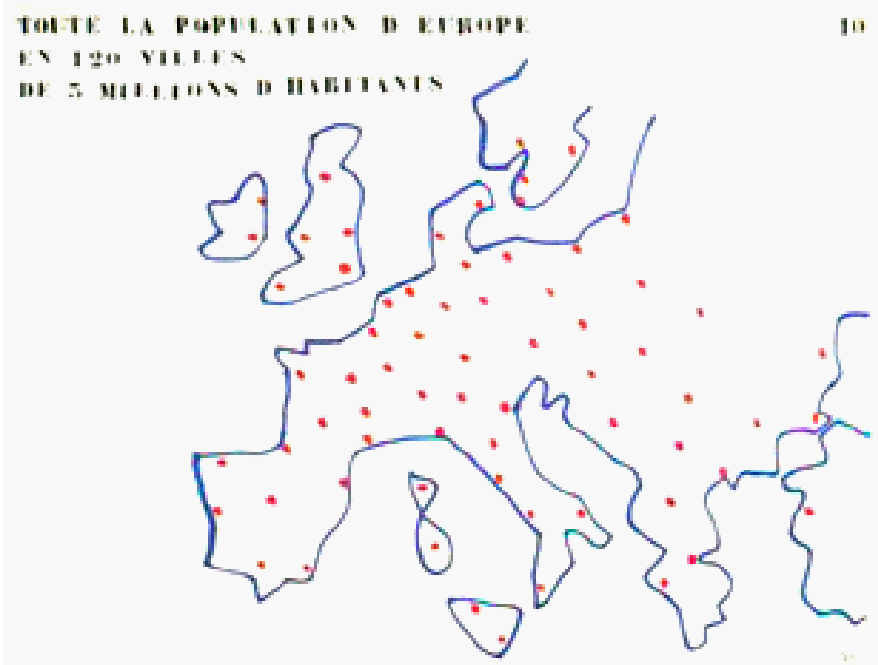

Figura 31: Princípio 10. Fonte:

(FRIEDMAN, 2006, p. 69). 


\subsubsection{A Influência da Cibernética nas cidades}

A Cibernética foi uma teoria largamente difundida e aplicada em diversos ramos do conhecimento e também no planejamento e controle das cidades. A cibernética é uma teoria que compreende o fenômeno de forma sistêmica e está preocupada com a relação ou comunicação entre os elementos que o compõem. Em seu desenvolvimento, apropriou-se de conhecimentos e pesquisas relacionadas com a mensagem e com a informação. $O$ amadurecimento científico da área foi reforçado pela revisão da cibernética nos anos 1960, incluindo um segundo observador que fazia parte do sistema. Valorizava o processo interno do sistema e importava-se essencialmente com o desenvolvimento do todo.

O objetivo inicial da cibemética era resolver problemas de previsão e controle. Norbert Wiener (1894-1964) trabalhou essencialmente na noção fundamental da mensagem para conseguir atingir a direção correta através da informação transmitida (FRANÇOIS, 1999, p.208). O propósito da cibernética era desenvolver uma meta-teoria para o problema do controle e da comunicação em geral, no sentido de diminuir a degradação orgânica, combater assim a entropia, e a tendência natural de aumentar a desordem em um sistema (WIENER, 1954, p. 17). Através do estudo dos mecanismos homeostáticos, o sistema buscava atingir a autorregulação e a consequente sobrevivência através de meios de interação dos seus elementos (PASK, 1961, p.13).

A preocupação da cibernética era saber como a estabilidade se mantinha pelos mecanismos de controle. Uma das primeiras iniciativas foi a invenção do termoregulador associado à velocidade de um motor a vapor de Watt no século dezoito (PASK, 1961, p.12). A associação entre as pesquisas sobre o cérebro humano e as máquinas era frequente, pois o estudo de um poderia ajudar no desenvolvimento do outro e vice-versa. 


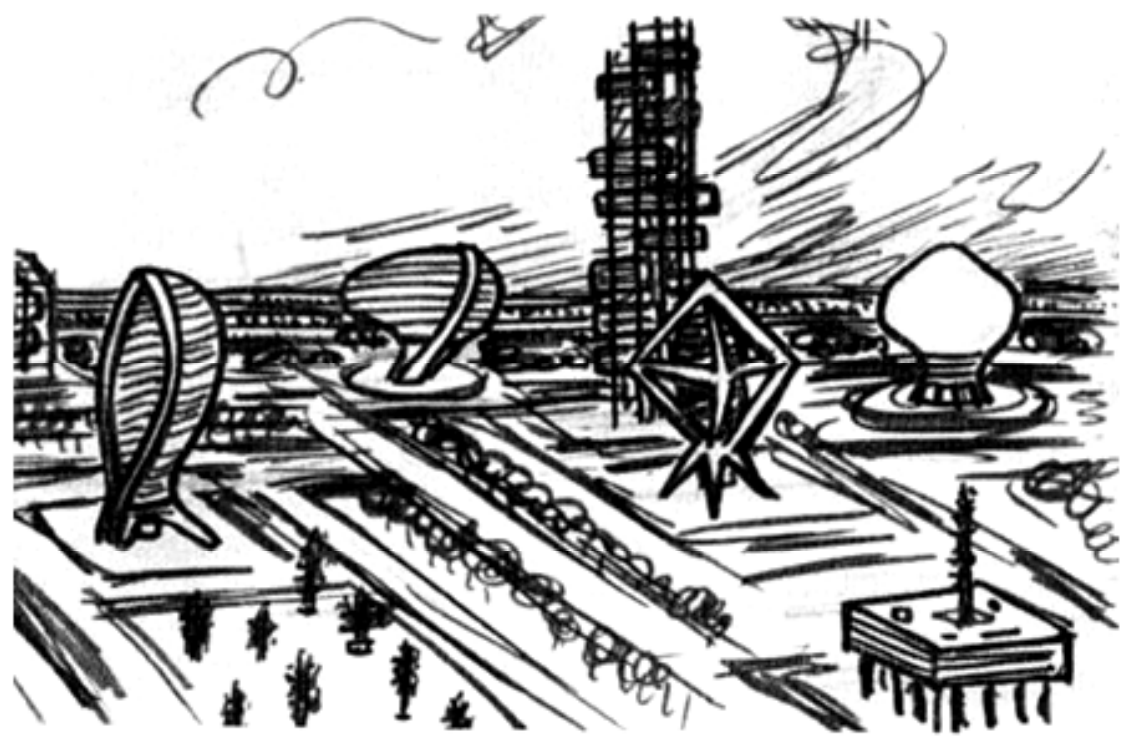

Figura 32: Nicholas Schöffer,

Cybernetic City (1955), rendering

Courtesy Eléonor Schöffer. Fonte:

(BUSBEA, 2007, p. 52). 
[...] a cibernética tenta encontrar os elementos comuns no funcionamento das máquinas automáticas e do sistema nervoso humano, e desenvolver uma teoria que irá cobrir todo o domínio do controle e da comunicação nas máquinas e nos organismos vivos.

(VON FOERSTER, 1974)

\section{A aplicação da Cibernética às cidades tinham em comum características denominadas por Busbea como:}

[...] parabolóides hiperbólicas, estruturas em grelha, cápsulas de plástico, conchas de concreto, e estruturas massivas sobre os territórios, conectando, comunicando, sobrepondo e integrando. Funções individuais foram substituídas por espaços multifuncionais ou polivalentes, composições arquitetônicas foram substituídas por constante mutação espacial e combinações, lares em locais isolados foram substituídos por liberdade de movimento; a forma arquitetônica local e específica se tornaram tecido urbano global ${ }^{51}$ (BUSBEA, 2007, p. 26, tradução nossa).

De acordo com o pensamento desses arquitetos, as cidades, na década de 1960, poderiam se modificar conforme as possibilidades da infraestrutura, e da mesma forma, seriam maleáveis suficientemente para se adequarem à transferência de local. Esse controle seria realizado por centros operacionais, com sistemas computacionais que enviariam e receberiam dados relativos à migração humana. A plataforma da cidade espacial era elaborada sobre uma estrutura, capaz de se estender em diversas camadas sobrepostas. Nessas sobreposições, estavam incluídas zonas de habitação, circulação, indústrias, lazer e espaços públicos.

Nicholas Schöffer, contemporâneo de Friedman, foi um dos principais teóricos a

51 Original em inglês: Hyperbolic paraboloids, space frames and grids, plastic pods, concrete shells, and massive megastructure spread across the landscape, connecting, communicating, overlapping, and integrating. Single functions were replaced with plurifunctional or polyvalent spaces architectural composition was replaced by constant spatial mutation and combinations, dwelling in a single place was replaced with freedom of movement; local and specific architectural form became global urban fabric" (BUSBEA, 2007, p. 26). 
trabalhar a cidade cibernética. Para Schöffer, as funções primordiais da cidade eram o trabalho, a moradia e o lazer, distribuídos em uma grande rede.

[...] ele imaginou uma cidade onde todas estas coisas foram levadas para um equilíbrio espacial baseada na auto-regulação do sistema de gerenciamento de dados $^{52}$ (BUSBEA, 2007, p. 54).

O controle da cidade seria realizado com máquinas computacionais que processariam os dados relativos ao espaço urbano, e assim controlariam as necessidades dos habitantes residentes nesse ambiente. Aqui, o pensamento cibernético era associado ao plano urbano. Como será explanado, a seguir, na descrição do método de trabalho de Yona Friedman.

$\mathrm{Na}$ era da sociedade da informação, como descreve Matterlart (2002), a comunicação e a transmissão das mensagens eram um dos principais objetos de estudo, pois se acreditava que a verdadeira liberdade estava relacionada ao acesso à informação. De acordo com esse pensamento, os grandes teóricos investiam no entendimento da transmissão das informações, tal como ocorreu nos estudos mais remotos de Alan Turin ${ }^{53}$ (1912-1954), que desenvolveu as máquinas eletromagnéticas, Claude Elwood Shannon (1916-2001) e Warren Weaver (18941978) que elaboraram a Teoria Matemática da Comunicação (1949), Norbert Wiener (1894-1964) a Cibernética (1948) e tantos outros posteriores a eles.

Para a constituição da cidade, esse raciocínio não era diferente, o processo de comunicação passou a ser ponto fundamental para garantir a liberdade e a autonomia do indivíduo. Foi por esse motivo que vários arquitetos e urbanistas, imbuídos da vontade de proporcionar o ambiente adequado para que o homem crescesse como indivíduo e fosse responsável por suas próprias atitudes, incorporaram máquinas que eram capazes de controlar, informar e ordenar o

52 Original em inglês: "[...] he envisioned a city where all these things were brought into a spatial equilibrium based on self- regulation system of data management. " (BUSBEA, 2007, p. 54)

53 Fundador da ciência da computação, o matemático, filósofo. 
desenvolvimento do ambiente urbano.

\subsubsection{A casa}

A casa é parte do sistema compreendido como habitat humano, e portanto a sua abordagem é a descrição do espaço na escala do individuo ou do agrupamento familiar dentro do ambiente urbano. O habitat da casa é entendido como unidade ou célula que compõe o organismo da cidade.

Friedman refletia a respeito do habitar desde sua formação. Ele considerava que a casa também era composta pela rua, pelo jardim, pelas outras casas e assim por diante. Ele também achava que cada indivíduo imaginava sua própria casa diferente da casa de outro indivíduo, e que cada mundo idealizado era diferente para cada indivíduo (FRIEDMAN, 2006, p. 9).

$\mathrm{O}$ arquiteto trabalhou sobre essas premissas por longo tempo. Ele tentava incorporar à técnica, questões de flexibilidade e uma estrutura que comportasse as diferentes escolhas dos diversos usuários. A tecnologia disponível era um meio para a elaboração dos elementos que formariam o habitat, por esse motivo, a pré-fabricação, a automação e a industrialização eram utilizadas para pensar o ambiente construído.

Friedman acolhia de modo operacional uma quantidade substancial de pessoas em um espaço urbano. Ele considerava que o espaço da cidade era o local para a população viver. Como cita:

[...] um homem nunca ocupa (dimensões mínimas necessárias para a visão, para a proteção e acessibilidade incluídas) um volume maior do que $40 \mathrm{~m}^{3}$. Numa cidade de um milhão de habitantes, o volume realmente utilizado é só de $40.000 .000 \mathrm{~m}^{3}$, o que corresponde a $2 \mathrm{~km} \times 2 \mathrm{~km} \times 10 \mathrm{~m}$ (a 7ạ. Circunscrição administrativa de Paris, com imóveis de dois andares): há, portanto, em Paris 18 circunscrições 
administrativas em 20 que só servem para armazenagem (FRIEDMAN, 1977, p. 87).

A elaboração do espaço passava pela multiplicação do território no espaço aéreo que, a seu ver, podia ser utilizado para abrigo de pessoas. Outro aspecto interessante é a visão de armazenagem que o arquiteto tinha. Ele parece considerar, pela declaração acima, que esse ambiente era subutilizado no contexto geral.

Outro aspecto considerado relevante sobre o habitar diz respeito aos agrupamentos familiares. Friedman e o GEAM reconheciam os agrupamentos familiares diferenciados que se formaram na época, tais como casais sem filhos, pessoas sós, famílias monoparentais dentre outros e, questionavam a organização de ambientes com a tripartição dos espaços de habitar (social, senviço e íntima) como conhecidos nas casas burguesas.

Além da espacialidade vista para a sociedade modificada no período estudado, Friedman usou materiais diversificados para a construção da casa. Os painéis préfabricados se tornaram populares já na década de 1940, segundo o depoimento de Friedman. Suas primeiras reflexões sobre habitação se relacionavam com um plano irregular amebóide capaz de se modificar. Nessa ocasião, pensou em utilizar painéis em forma de biombos ligados por dobradiças. Respondendo a essa mesma lógica, trabalhou sobre o que ele denominava de elementos "quase-móveis" que eram mobiliários com função de banheiro, cozinha e WC. Esses mobiliários colocados em posições distintas separariam os espaços internos, formando outros subespaços que dividiriam o espaço doméstico.

Umas das questões que considerou de difícil resolução foi o telhado, pois necessitava de uma forma diferente dos planos de fechamento. Então, criou uma estrutura geométrica de telas dobráveis.

Quando Friedman pensava em projetos habitacionais, imaginava um grande 
espaço vazio que não utilizasse a tripartição clássica e onde os habitantes pudessem mover instalações portáteis de acordo com o seu desejo. Essa casa, composta por planos irregulares, sem uma forma definida, de painéis pré-fabricados, tinha a capacidade de se modificar através da flexibilidade dos elementos que, ao se agregarem, davam a possibilidade de inúmeras configurações. Os dispositivos elétricos de banheiros e cozinhas, ligados à rede de serviços públicos e rede de drenagem de água com tubos flexíveis de plástico, permitiriam ser transportados de um lado para outro. O WC poderia girar em torno do tubo de drenagem principal (FRIEDMAN, 2006). Friedman explica:

[...] Arquitetura Móvel vai muito além da imagem puramente técnica que eu dei do vazio "estruturado" em que o volume de material é quase dissolvido, cujos volumes de configurações, neste vazio, são determinados pelos desejos invisíveis, pela livre vontade dos usuários ${ }^{54}$ (FRIEDMAN, 2006, p. 30).

Nesse conceito descrito por Friedman, percebe-se um olhar diferenciado sobre a arquitetura móvel, agora não como valorização da mobilidade do homem na cidade, mas a valorização da mobilidade do próprio espaço através da movimentação de todos os elementos do ambiente, tanto dos painéis de fechamento como dos equipamentos funcionais. Esse olhar sobre a flexibilidade do espaço parece se diferenciar daquele defendido no Movimento Moderno em que a estrutura é independente do sistema de vedação e do layouta ser escolhido. Aqui a flexibilidade foca a mobilidade como elemento de liberdade.

Desse modo conforme descrito, a habitação passa por uma forma diferenciada de compreensão enquanto ambiente doméstico. Agora como abrigo, que pode ser conectado aos serviços públicos de infraestrutura urbana, preferencialmente individual.sem a lógica da tripartição (serviço, íntima e social). A configuração do 54 Original em inglês: Mobile Architecture goes far beyond the purely technical image I gave of the "structured emptiness" in which material volumes are nearly dissolved, volumes whose configurations, in this emptiness, are determined by the invisible desires, by the free will of the users "(FRIEDMAN, 2006, p. 30) 

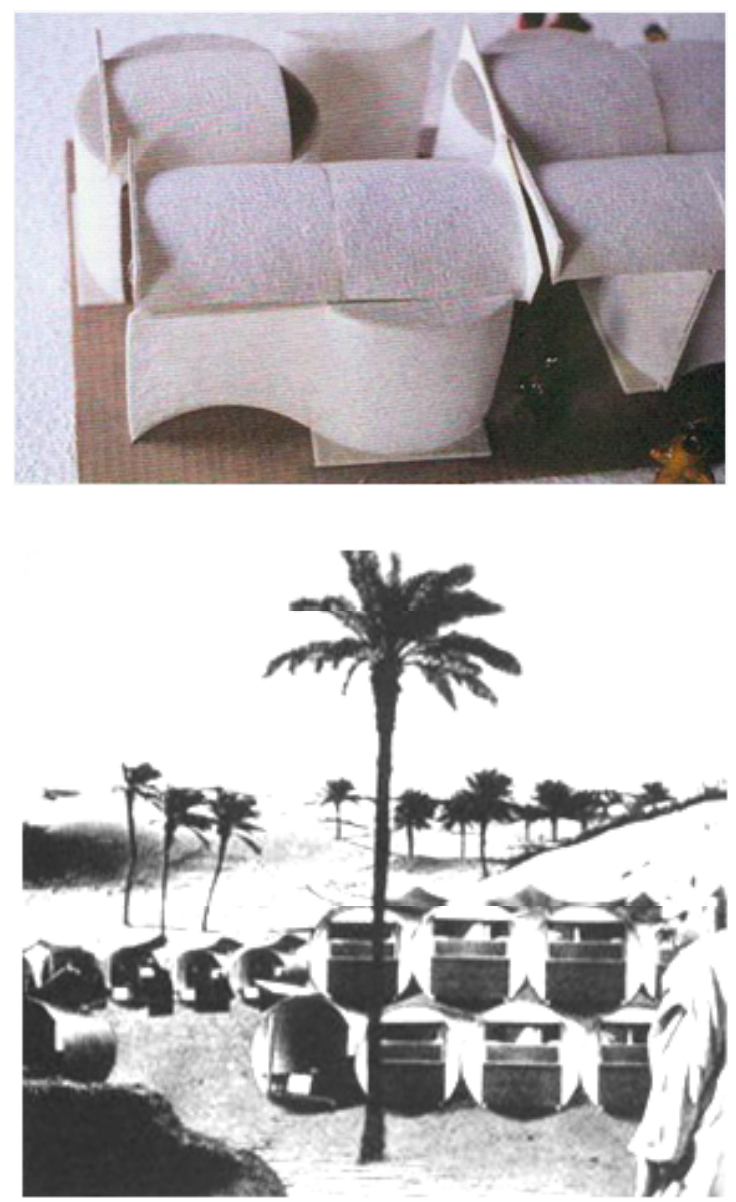

Figura 33: Casa feita com planos curvos.

O mesmo painel serve como elemento

de fechamento e cobertura. (Israel,

1953). Fonte: (FRIEDMAN , 2006, p. 12).

Figura 34: Yona Friedman with J ean-

Pierre Pecquet, Cylindrical Shelters

(1958). Courtesy Yona Friedman. Fonte:

(BUSBEA, 2007, p. 66) 
habitar é vista como parte de um sistema maior que é a cidade, que deve suprir todas as necessidades dos usuários, como trabalho, moradia, alimentação, lazer, sexo, circulação, dentre outros.

\subsection{Abordagem Metodológica}

A maneira de compreender o usuário na forma de ver deYona Friedman constituiria a base para elaborar o método de configuração da moradia e a organização das Estruturas Espaciais. Friedman explorou várias teorias científicas, tais como a Teoria Geral de Sistemas e as Teorias da Comunicação para elaborar a sua metodologia.

Em sua descrição do processo de projeto convencional para a produção do habitat, o usuário expunha ao arquiteto as suas necessidades, e o arquiteto traduzia essas necessidades em um objeto construído que ele denominava de hardware (FRIEDMAN, 1973, p.17).

Nesse ciclo, Friedman considerava que:

[...] o arquiteto (urbanista ou planejador) e o artesão eram apenas o "canal" através do qual o "conteúdo" da informação (ou "mensagem"), ou seja, as necessidades específicas do usuário, eram "transmitidas" à "matéria-prima" ("hardware") 55 (FRIEDMAN, 1973, p.18, tradução nossa).

Aqui se percebe a importância que o arquiteto dá à informação transmitida. Ele coloca no diagrama algumas variáveis próprias dos processos comunicativos, que são o emissor da mensagem representado pelo usuário; o receptor traduzido pelo produto tangível ou como ele chamava: hardware; o meio ou canal, que passam pelos profissionais que realizam a tradução da mensagem; e o retorno da mensagem quando o usuário utiliza o seu produto tangível.

55 Original em espanhol: el arquitecto (urbanista o planificador) y el artesano eran sólo el "canal" a través del cual el "contenido" de la información (o "mensaje"), es decir, las necesidades específicas del usuario, era "transmitido" hasta el "producto en bruto" ("hardware") (FRIEDMAN, 1973, p.18). 


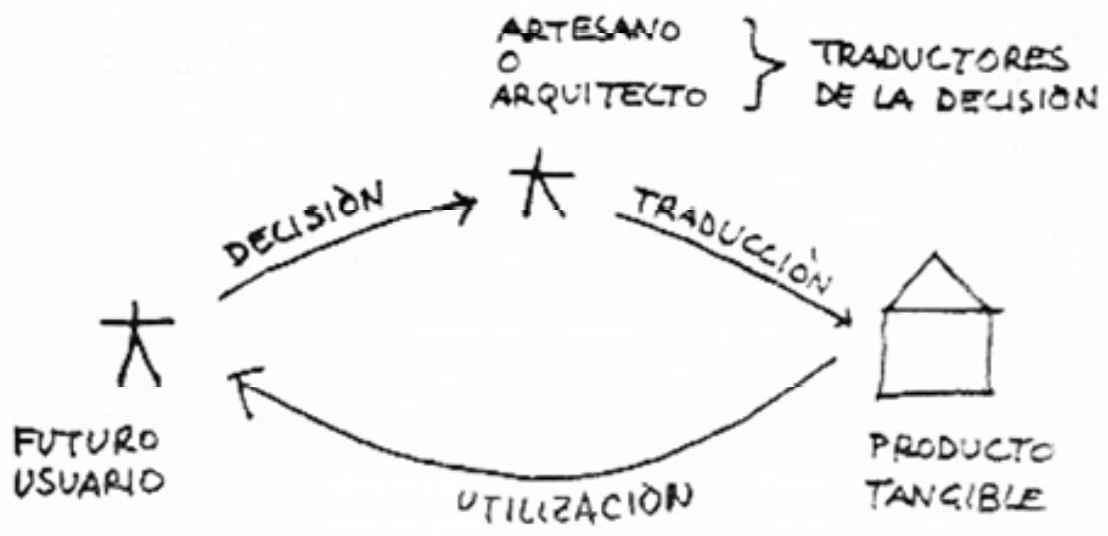

Figura 35: Diagrama explicativo do processo de design convencional Fonte: (FRIEDMAN, 1973, p.18).

A transmissão da informação era fundamental para o contexto do período de 1960, pois com o aumento da população nas cidades e a consequente demanda por habitações, o problema seria solucionado com o agrupamento das necessidades, classificadas para um homem tipo (fig. 35). 0 arquiteto traduziria essas necessidades em um produto tangível também tipo. Mas Friedman defendia que de fato o homem tipo não existia, e as necessidades eram únicas e individuais.

[...] Em 1958, eu escrevi que o homem tipo não existe. E quanto à idéia da importância do indivíduo, a imprevisibilidade de seu comportamento que não pode ser descrita com as abreviações [... ${ }^{56}$ (FRIEDMAN, 2006, p. 15, tradução nossa)

56 Original em inglês: [...] In 1958, I wrote that the average man does not exist. And regarding the idea of the importance of the individual, the unpredictability of his behavior which cannot be described with abbreviations[...](FRIEDMAN, 2006, p. 15) 


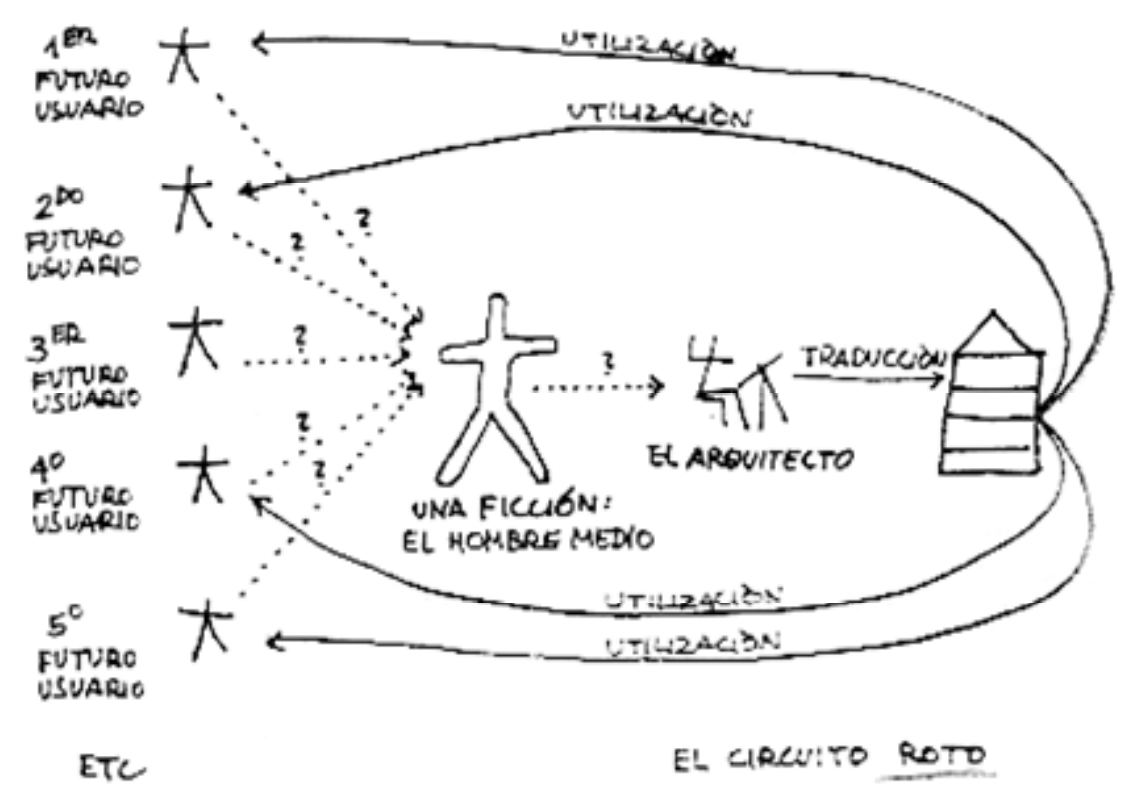

Figura 36: Diagrama de processo de projeto tradicional associado ao aumento de população. Fonte: (FRIEDMAN, 1973, p.21).

Friedman considerava que o manejo da informação, por parte do arquiteto ou do artesão, era o ponto vulnerável do sistema, ao traduzi-la no objeto final ou "hardware". A intenção de Friedman era elaborar um processo que eliminasse esse ponto, o curto-circuito da informação e, portanto, a falta de confiabilidade na chegada da mensagem, que poderia criar um ruído (FRIEDMAN, 1973, p.23). Para o arquiteto, a interferência ou avaliação de outra pessoa no processo de idealização da casa era considerada uma análise ou interpretação, que poderia ser equivocada, por esse motivo, ele preferia que o profissional arquiteto estivesse em um espaço paralelo. 


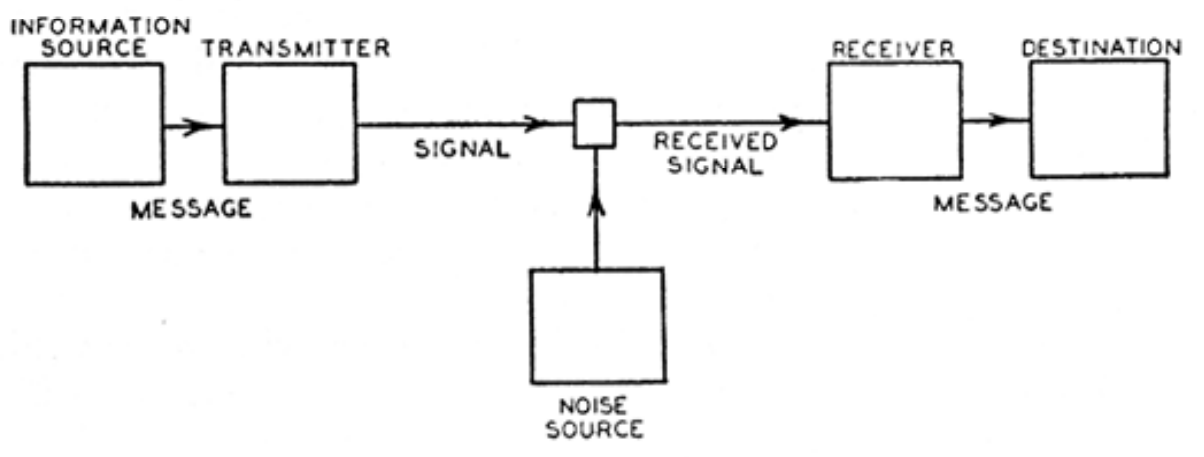

Figura 37: Diagrama de Shannon \& Weaver (1948). Fonte: (SHANNON, \& WEAVER, W. 1949).

O estudo do ruído dentro de um sistema foi analisado inicialmente na Teoria Matemática da Comunicação de Claude Elwood Shannon e Warren Weaver. Para eles, o principal problema da comunicação era reproduzir exatamente uma mensagem em outro ponto. Nessa teoria, as questões semânticas da comunicação eram irrelevantes do ponto de vista da engenharia. (SHANNON \& WEAVER, 1949) 
Como demonstra o diagrama a seguir, a Teoria Matemática da Comunicação compreendia um sistema de comunicação composto por 5 partes:

1. Uma fonte de informação que produzia uma mensagem ou sucessão de mensagens a serem comunicadas ao receptor final, como: cartas, rádio, telefone, televisão, sistema de som tridimensional ou sistemas em que o serviço atendia a diversos canais individuais, TVs coloridas e TVs associadas com canal de áudio.

2. Um transmissor que operava na mensagem de algum modo para produzir um sinal satisfatório para transmissão pelo canal.

3. O canal era o meio usado para transmitir para o receptor. Poderiam ser dois fios, um cabo coaxial, uma faixa de frequências de rádio, etc.

4. 0 receptor geralmente executava a operação inversa, realizada pelo transmissor, reconstruindo a mensagem vinda do sinal.

5. O destino era a pessoa ou coisa para a qual a mensagem era intencionada.

Um sexto elemento era o ruído, um fator disfuncional: qualquer interferência com o envio da mensagem através do canal (como o estático no telefone ou rádio) que podia conduzir ao sinal recebido diferente do enviado57 (SHANNON \& WEAVER, 1949).

O sexto elemento era um componente importante, apesar de Shannon não o classificar dentre os elementos que fazem parte do processo de comunicação.

Para a resolução do problema de ruído, Yona Friedman eliminou o arquiteto do processo de comunicação entre usuário e objeto construído, pois o considerava como ponto de estrangulamento do ciclo. Como mostra o diagrama a seguir (fig. 38), o usuário entrava em contato com um determinado repertório possível de soluções. Durante a escolha, era advertido sobre os problemas que pudesse ter,

57 Original em inglês: A sixth element, noise is a dysfunctional factor: any interference with the message travelling along the channel (such as 'static' on the telephone or radio) which may lead to the signal received being different from that sent. (SHANNON \& WEAVER, 1949) 


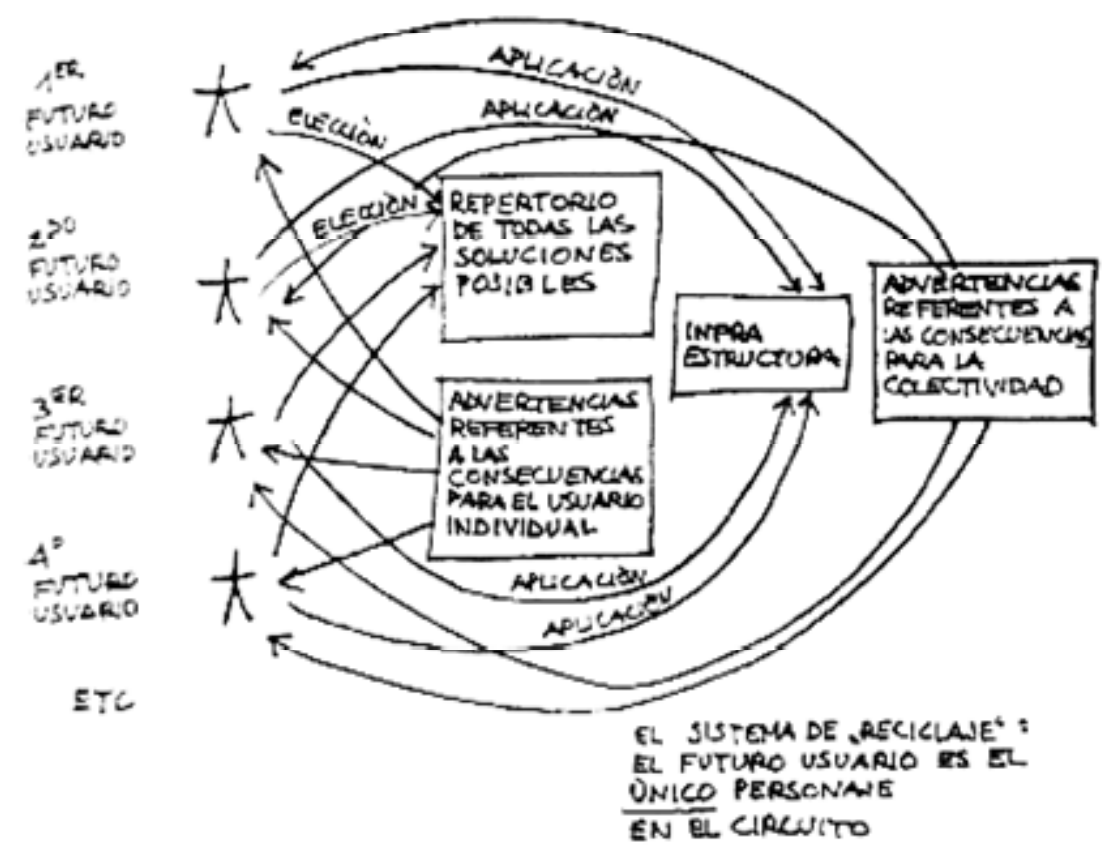

Figura 38: Diagrama do processo de produção do habitat. Fonte: (FRIEDMAN, 1973, p.23).

tanto em nível individual como no coletivo. Dessa forma, com a utilização desse formato, o usuário dispunha de um código do repertório que correspondia à sua escolha. $\mathrm{O}$ artesão ou a indústria fabricaria o objeto do repertório escolhido (FRIEDMAN, 1973, p.24). 


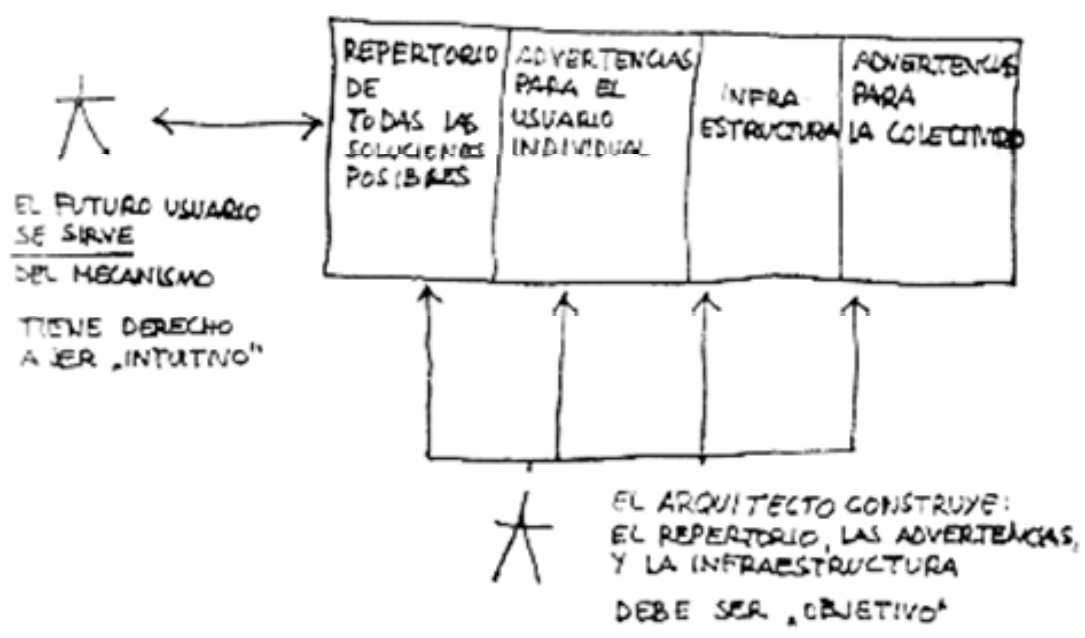

Figura 39: Diagrama das responsabilidades do arquiteto e competências dos usuários. Fonte: (FRIEDMAN, 1973, p.25).

O arquiteto, segundo os esquemas (fig. 39) de Friedman, era o responsável pela criação do repertório de possibilidades, das advertências individuais e coletivas e pela elaboração da infraestrutura que receberia o habitat selecionado pelo usuário. O usuário por sua vez era responsável pela sua escolha e estava informado das 
advertências possíveis (FRIEDMAN, 1973, p.25).

Nesse diagrama, Friedman defendia a participação do usuário, que tinha responsabilidade sobre suas opções, ele era um ator no processo. $O$ profissional arquiteto, por sua vez, era o responsável pela produção das matrizes que poderiam ser configuradas e adequadas ao usuário. $\mathrm{O}$ arquiteto fazia parte do processo em um ambiente paralelo ao processo entre usuário e objeto.

\title{
2.5. O Pensar sistêmico e o exemplo do Flatwriter
}

Quando Friedman discorria sobre o método que utilizava para explicar seu enunciado a respeito do processo de design, usava como base de entendimento do fenômeno o sistema, e explicava o que compreendia por sistema e estrutura:

\begin{abstract}
Sistema é um conjunto de elementos ligados a esse conjunto - ou relacionados a ele - pelo menos por uma conexão - ou relação sem que essas relações apresentem necessariamente uma certa regularidade. Igualmente definiremos estrutura como o conjunto de relações entre os subconjuntos de um conjunto e onde, portanto, necessariamente existem regras de composição dos elementos entre si. Todas as estruturas são, portanto, implicitamente, um sistema sem que isso signifique que um sistema possui uma estrutura de forma implícita58 (FRIEDMAN, 1973, p. 29, tradução nossa).
\end{abstract}

Os sistemas eram descritos por axiomas, condições para que o sistema existisse. A principal condição do axioma no sistema de Friedman era um espaço em que o ser humano pudesse sobreviver, o que ele denominava de biosfera. O compromisso dos arquitetos para a produção do repertório era trabalhar nessa biosfera a partir

\footnotetext{
58 Original em espanhol: [...] conjunto de elementos conectados a dicho conjunto - o relacionados con él - al menos por una conexión - o relación - sin que estas relaciones presenten necesariamente una determinada regularidad. Igualmente definiremos "estructura" como el conjunto de relaciones entre los subconjuntos de un conjunto y donde, por tanto, existen necesariamente reglas de composición de los elementos entre si. Toda estructura será, por consiguiente, implícitamente, un sistema, sin que ello quiera decir que un sistema posea implícitamente una estructura.) (FRIEDMAN, 1973,p. 29)
} 
das seguintes premissas axiomáticas: 1 . o espaço que ele produz é fechado, 2. tem que possuir no mínimo um acesso e, 3. Havia pelo menos dois tipos de espaços separados (FRIEDMAN, 1973, p. 40).

Com essas premissas, o arquiteto era capaz de organizar todas as possibilidades necessárias para a constituição do repertório. Friedman (1973) utilizava o exemplo do menu de um restaurante para explicar como funcionava a escolha de um objeto a partir de um repertório. Essa associação começava quando o cliente-usuário, com as suas necessidades de se alimentar entrava em um restaurante. Em um menu (repertório) verificava todas as possibilidades, os preços e a explicação de cada prato. O cliente ficava bem informado simplesmente entrando em contato com o menu. Usando as informações disponíveis, o cliente era capaz de fazer sua escolha e compor diferentes pratos de acordo com a sua vontade. (FRIEDMAN, 1973, p. 49)

O trabalho do arquiteto era estabelecer o repertório e indicar os possíveis problemas (ou advertências) que os usuários pudessem ter de acordo com a seleção. A base da construção desse repertório era prever todas as possibilidades para o usuário. Dentre essas possibilidades, encontravam-se milhões de alternativas que estariam disponíveis para que os usuários as combinassem através de um computador simples que se parecia com uma máquina de escrever de fácil manuseio. A essa máquina Friedman denominava Flatwriter:

[...] uma máquina que permite que cada futuro morador da cidade possa imprimir suas preferências pessoais sobre sua futura habitação, graças à ajuda de "símbolos" que representam os diferentes elementos da sua decisão, de tal forma que possa ser igualmente entendido pelo mestre de obra e por qualquer outro vizinho. Dito de outra forma, esta máquina "contém" um repertório de vários milhões de planos de habitação potencial, sabe como calcular os problemas sobre o impacto dos recursos que envolvem o modo de utilização possível de cada futuro usuário (morador) individualmente e finalmente pode calcular se a ordem escolhida pelo futuro habitante ameaça ou 

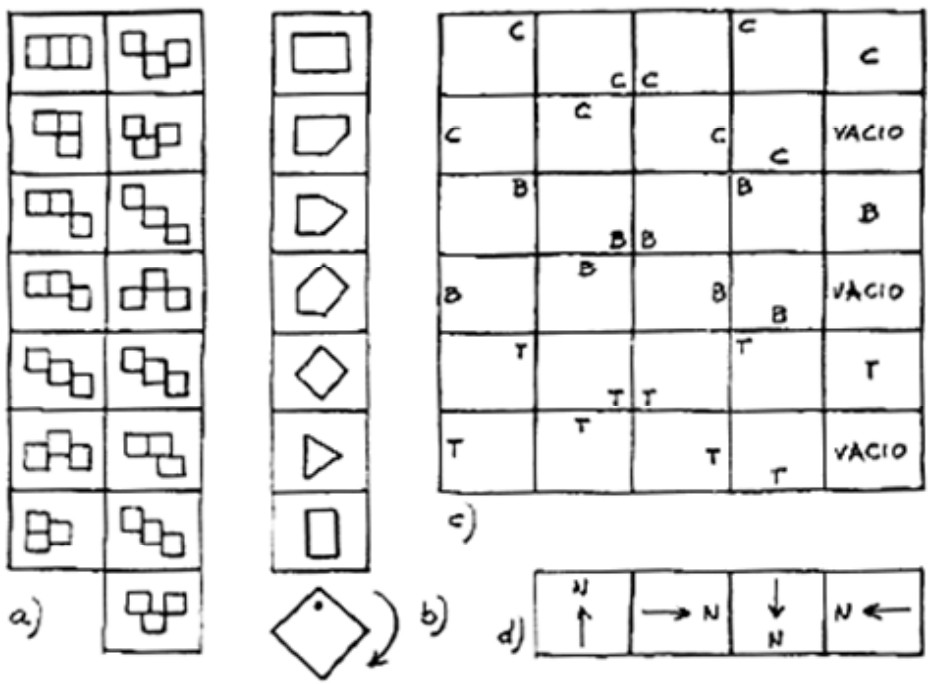

c)
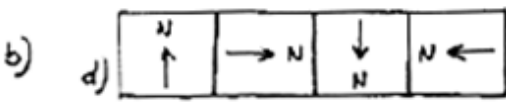

Figura 40: Tipologias de ambientes para configuração do habitat. Fonte: (FRIEDMAN, 1973, p. 7).

não perturbar as outras pessoas ${ }^{59}$ (FRIEDMAN, 1973, p. 68, tradução nossa).

\section{Essa máquina continha as opções a serem configuradas, como ilustra a figura acima $^{60}$ (FRIEDMAN, 1973, p. 70):}

59 Original em espanhol: una "máquina" que permite que cada futuro habitante de una ciudad pueda imprimir sus preerencias personales en punto a su futura vivienda, y ello gracias a la ayuda de símbolos" que representan los diferentes elementos de su decisión, de tal manera que ésta pueda ser igualmente entendida por el capataz de la obra que por cualquier otro habitante vecino. Dicho de otra forma, esta máquina "contiene" un repertorio de varios millones de planos de posibles viviendas, sabe calcular las "advertencias" en punto a las consecuencias características que implica el modo de uso eventual de cada futuro habitante (usuario) individual, y, por último, puede calcular si la ordenación escogida por un futuro habitante amenaza o no con molestar a los demás habitantes". (FRIEDMAN, 1973,P. 68)

60 Original em Espanhol: a) Todas las uniones y configuraciones que pueden existir entre tres volúmenes 
a) Relação de todas as uniões e configurações que podem existir entre três volumes por exemplo.

b) Todas as formas que cada volume pode tomar em função das unidades (e em um contexto técnico definido de antemão).

c) Todas as posições que o equipamento da cozinha, o banheiro e o WC podem ocupar em um volume dado.

d) Todas as orientações climáticas que pode ter a habitação.

Na escolha das configurações, as opções eram por exemplo:

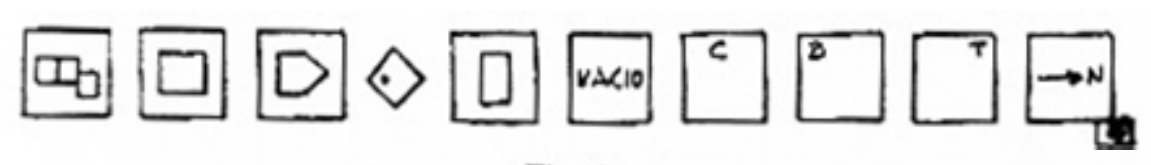

Fig. 31

el «Flatwriter» imprimizá el plano siguiente:

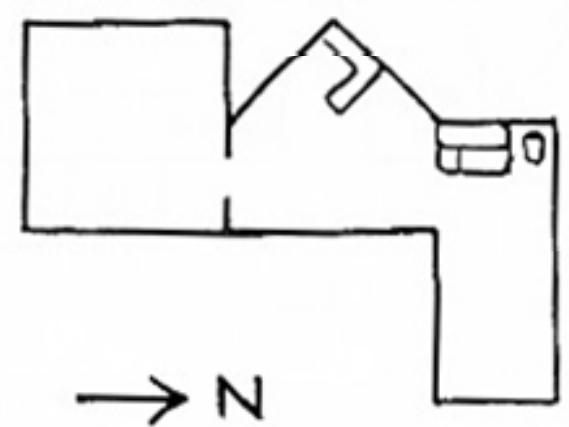

Figura 41: Resultado da escolha do usuário Fonte: (FRIEDMAN, 1973, p. 71). 
A seguir, a máquina imprimia o preço de acordo com a escolha do usuário. Sequencialmente, o usuário fazia uma discriminação do seu modo de vida, que seria traduzido em utilização do ambiente de acordo com os espaços eleitos.
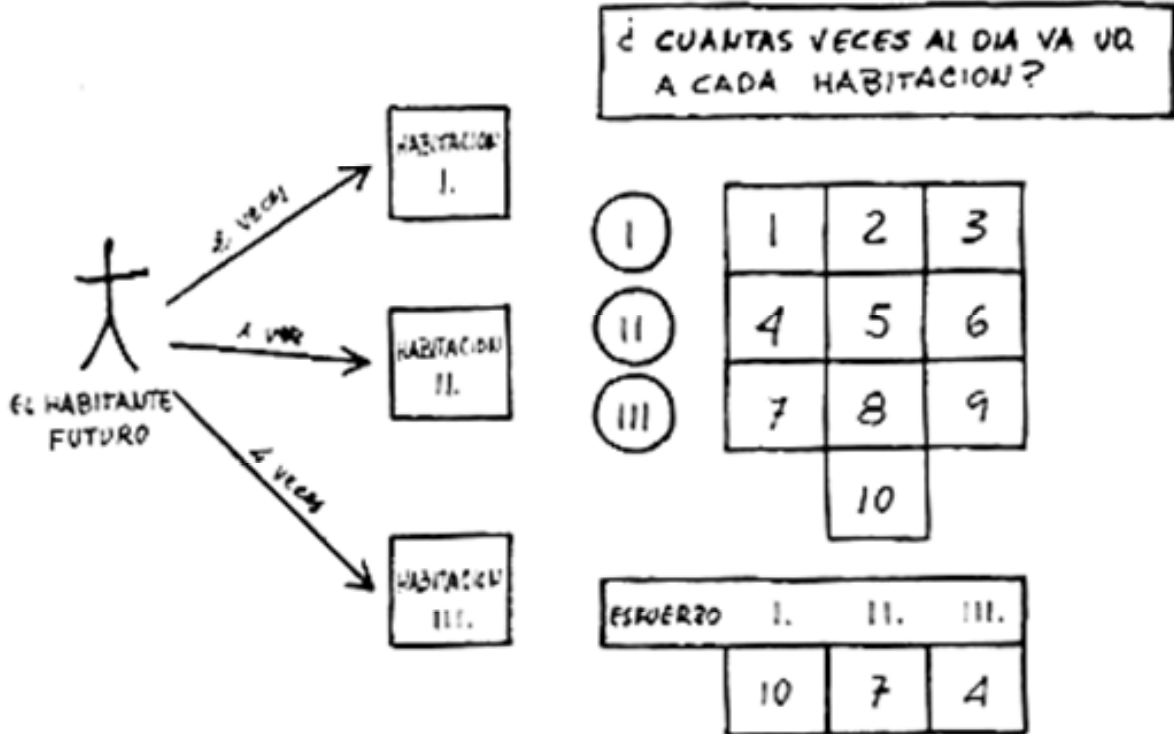

Figura 42: Tradução dos modos de vida e uso dos ambientes da habitação Fonte: (FRIEDMAN, 1973, p. 72). 
Com os dados colocados na máquina, o equipamento fazia um cruzamento das informações, retornando ao usuário o espaço encomendado de acordo com a sua real necessidade. Nessa ocasião, o futuro habitante poderia reeleger um novo espaço que mais the conviesse (FRIEDMAN, 1973, p. 72).

Após essa etapa, a máquina reproduzia a planta da infraestrutura (megaestrutura) para que o usuário pudesse escolher o local de sua habitação entre os locais vazios. A máquina mostrava uma simulação com o espaço configurado no local desejado. Após essa etapa, a máquina fazia todos os cálculos para a verificação das necessidades na infraestrutura urbana e informava aos vizinhos sobre a chegada do novo morador.

Finalmente, Friedman concluía dizendo que:

O "Flatwriter" permite que cada usuário de uma futura cidade (infraestrutura de uma):

a) Escolha o nível e as características da sua casa (ambiente individual), uma atividade que é atualmente desempenhada pelos Arquitetos;

b) Escolha a situação do seu entorno na cidade e receba uma "permissão para construção" imediata, atividade que é atualmente desempenhada pelo urbanista e pelo município;

c) Seja informado das consequências particulares que atingem diretamente a si e sua morada, o que ocorre toda vez que haja uma nova eleição ou decisão na cidade.

O "Flatwriter" é pois a aplicação de um novo processo de informação entre o usuário e o objeto de seu uso, permite uma decisão individual quase ilimitada e uma oportunidade direta para corrigir seus próprios

(por ejemplo, y para simplificación de las ilustraciones; b) todas las formas que cada volumen puede tomar en función de esas uniones ( $y$ en un contexto técnico definido de antemano); c) todas las posiciones que el equipamiento de la cocina, el cuarto de banõ y el W.C. pueden ocupar en un volumen dado; d) todas las orientaciones climáticas que puede tener la vivienda". (FRIEDMAN, 1973,P. 70) 


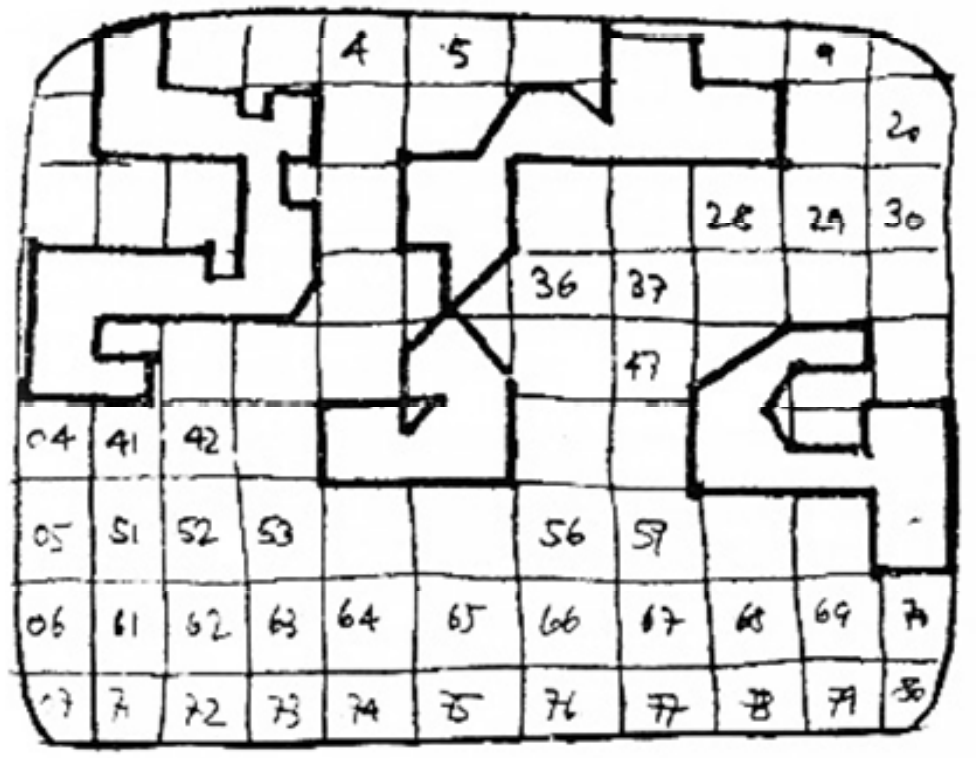

Figura 43: Planta da infraestrutura

que acolherá o habitat.

(FRIEDMAN, 1973, p. 72) 
erros sem a intervenção dos profissionais "intermediários ${ }^{61}$. (Friedman, 1973, p. 76, tradução nossa).

Diante dessa explanação, percebe-se que Friedman agregava vários conceitos para a formação de um sistema de construção de cidade que saía dos moldes tradicionais. Havia como pano de fundo, uma máquina que controlava todas as ações dos envolvidos no processo. Como um grande sistema de jogo em que os habitantes pudessem, através dele, entrar ou obter dados de acordo com a sua necessidade e atuação. Friedman via de alguma forma, pela sua teoria, o potencial da automação aplicada ao planejamento urbano.

Apesar de considerar que a cidade era um ambiente construído pelos próprios usuários, ele também apontava que o espaço das megaestruturas podia ser selecionado pelos habitantes, observando uma simulação computacional. O usuário podia escolher, mas essa escolha partia de regras absolutamente parametrizadas.

A sugestão de Yona Friedman expunha um pensamento visionário que contribuiu para várias ideias projetuais de arquitetos de seu período. O ponto importante de sua teoria era que ele agregava as novas teorias emergentes da comunicação em sua metodologia de projeto.

Apesar de não terem sido realizadas pesquisas extensas sobre a influência do conceito das Megaestruturas como modelo de habitat no Brasil, verirficou-se que o arquiteto Sérgio Bernardes pode ter sido um desses exemplares.

61 Original em espanhol: “El "Flatwriter" permite a cada futuro usuário de uma ciudad (de uma infraestructura):

a) Escoger El plano y las características de su vivienda (su entorno individual), actividad que desempeña actualmente el arquiteto;

b) Escoger la situación de su entorno en la ciudad y recibir un "permiso de construcción" inmediato, actividad que desempeña actualmente el urbanista y el municipio;

c) Estar informado de las consecuencias particulares que le atañem directamente, a él y a su habitar, cada vez que tiene lugar una nueva elección o una decisión en la ciudad. 


\subsection{Sérgio Bernardes no Brasil}

As propostas de megaestruturas sugeridas na Europa no decorrer da década de 1960 tiveram pouca repercussão no Brasil. Segundo OSEKI (1982), os investimentos posteriores a 1960 concentraram-se nas "áreas de infraestrutura urbana, transportes, comunicação, estradas, em uma política de integração nacional". (OSEKI, 1982, p. 120 apud SEGAWA, 2002, p. 160) Em relação aos projetos desenvolvidos por arquitetos, estavam voltados para obras ligadas às indústrias automobilística, química, têxtil e alimentar.

Enquanto em vários locais da Europa se propunha projetos de megaestruturas para dar conta da demanda populacional, dos modos de vida emergentes e dos congestionamentos de veículos automotores, o Brasil vivia a construção de Brasília, sob a forte influência da arquitetura moderna representada por Oscar Niemayer e Lúcio Costa.

Outros arquitetos como Vilanova Artigas, Lina Bo Bardi, Paulo Mendes da Rocha, desenvolveram projetos de escolas, museus e residências. No cenário arquitetônico, além do ideário brutalista, havia um interesse pela industrialização da construção e pela utilização de novas tecnologias.

Acompanhando a produção europeia das megaestruturas, no Brasil, o arquiteto Sérgio Bernardes, do Rio de J aneiro, propôs, a pedido da Revista Manchete, um ensaio para a cidade do Rio do Futuro. Nessa ocasião, ele elaborou um plano para a cidade, com elementos semelhantes às megaestruturas espaciais, com sistema de circulação e edifícios para habitação.

Segundo Nobre (2008), esse projeto era uma provocação ao Plano Doxiadis que tinha o intuito de determinar "o desenvolvimento urbano do novo estado da Guanabara, prevendo sua expansão até o ano 2000" (NOBRE, 2008, p. 112). O Plano Doxiadis trazia algumas poucas propostas de projetos-piloto de habitação social 
apresentadas como apêndice.

A pesquisadora Ana Luiza Nobre investigou extensamente a produção desse arquiteto em sua tese de doutorado ${ }^{62}$ e afimou que essa publicação associava a era eletrônica, com o uso de computadores, aos novos modos de vida da cidade, juntamente com uma visão futurista de ficção científica. $O$ artigo, publicado em abril de 1965, por sugestão do editor trazia imagens da cidade com características de megaestruturas era impregnada das teorias discutidas na Europa.

A imagem da figura 44 traz temáticas como o homem daquela época, um homem da idade da pedra, um astronauta e um foguete espacial. Nestas cenas, Bernardes parecia propor as divergências entre o avanço da tecnologia, a conquista do espaço e o homem pré histórico.

Na proposta para o Rio de J aneiro do futuro (fig. 45 e 46), o arquiteto usou grandes estruturas para abrigar habitações e deixou o centro livre para uso coletivo, mesmo conceito presente nas megaestruturas dos arquitetos do Grupo de Estudos da Arquitetura Móvel, desenvolvida nesse capítulo. E no hotel Tropical em Recife (fig 47), Sérgio Bernardes aparenta aplicar o conceito de hélice, semelheante aos projetos desenvolvidos pelos japoneses que será desenvolvido no próximo capítulo.

De acordo com depoimentos de Nobre ${ }^{63}$, Sérgio Bernardes era um arquiteto curioso às novas tendências na área da arquitetura, e estava presente nos eventos profissionais que aconteciam na Europa e Estados Unidos, o que comprova sua atualização em relação aos temas emergentes no contexto da década de 1960 na arquitetura.

No Brasil, apesar desse ítem propor um breve olhar sobre o território brasileiro, pode-se observar um pequeno ensaio em que Bernardes assimilou os conceitos

62 NOBRE, A. L. Fios Cortantes: Projeto e Produto, arquitetura e design no Rio de Janeiro (1950-70), Tese (Doutorado em História Social da Cultura), Departamento de História, Pontifícia Universidade Católica do Rio de Janeiro, 2008.

63 Em visita a São Carlos, realizada em março de 2010. 


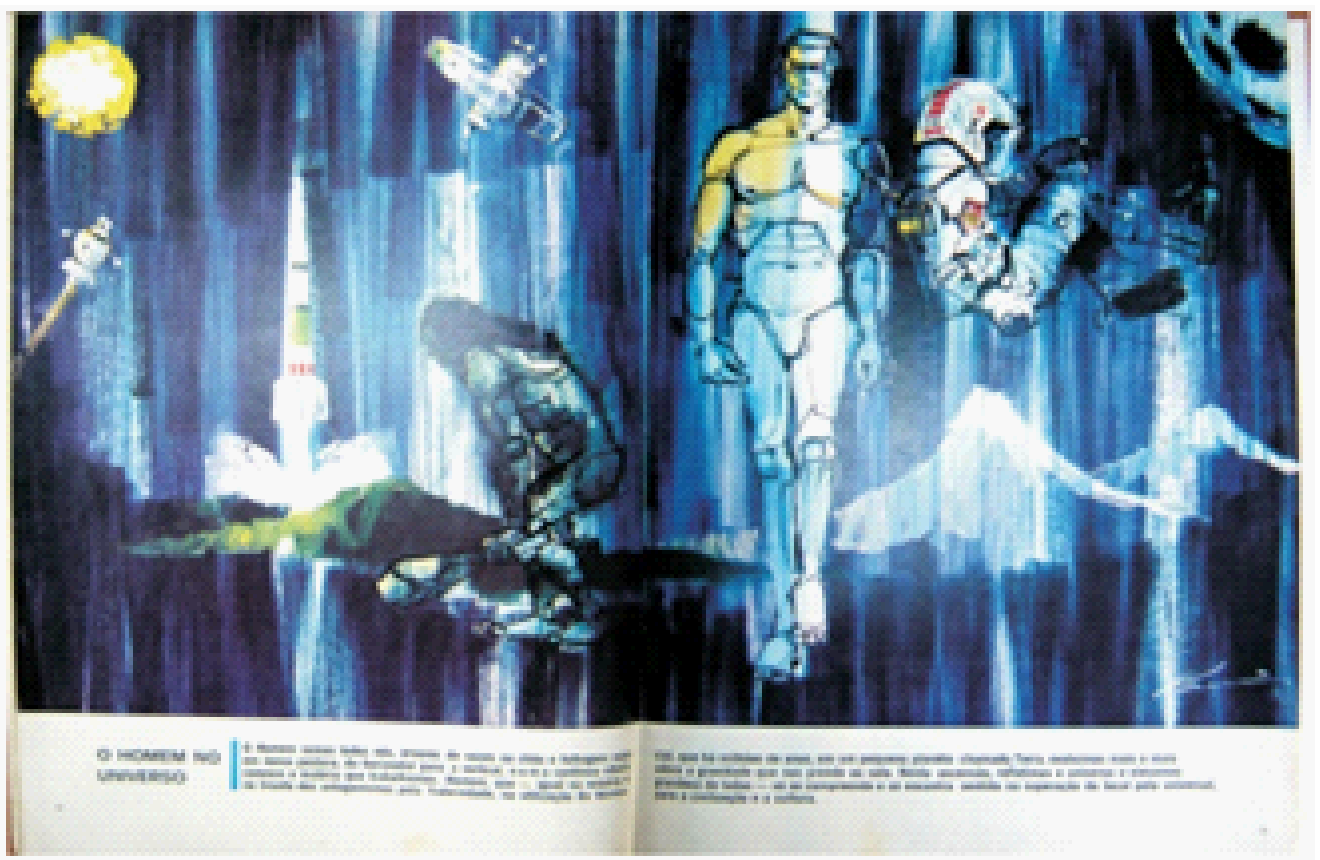

Figura 44: llustração do ambiente para o projeto Fonte: Revista

Manchete - Edição especial, abril

1965, apud NOBRE, 2008, p. 269 


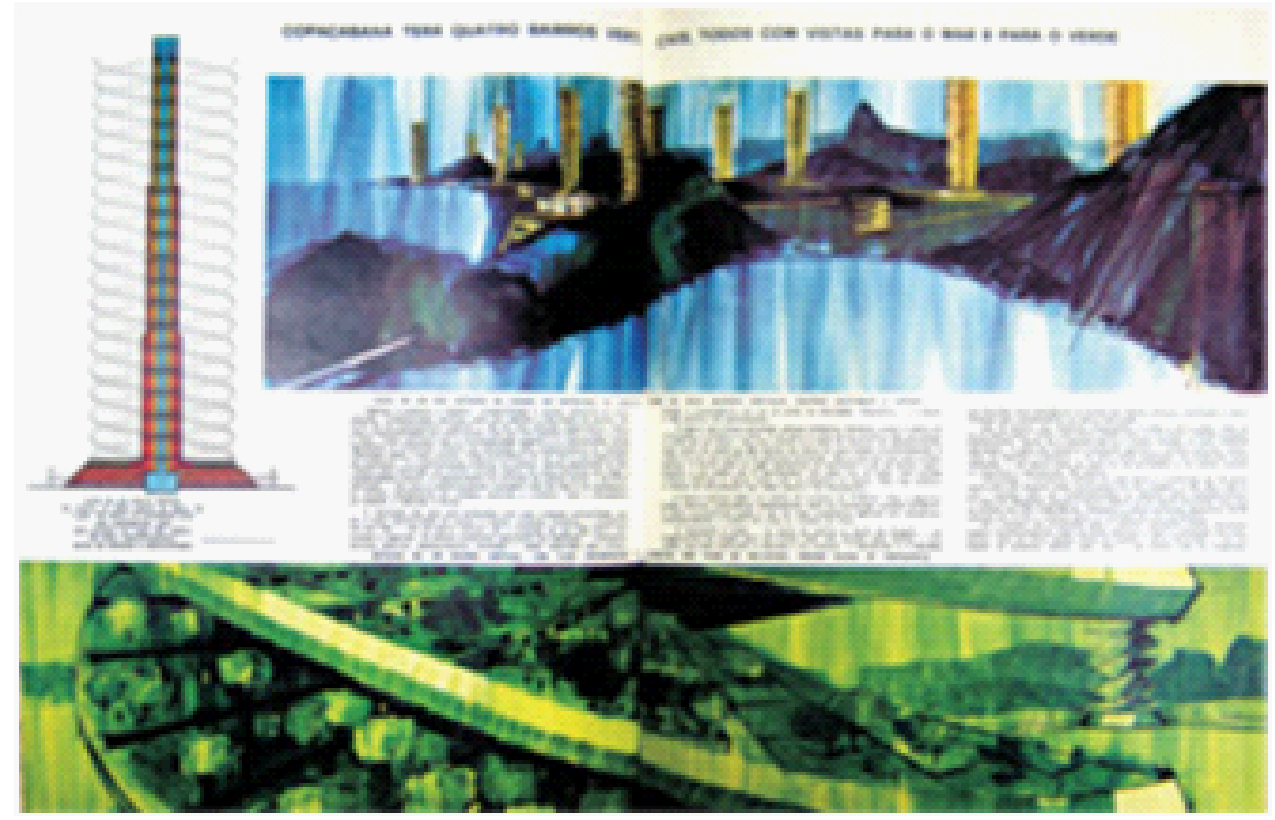

Figura 45: Sugestão da cidade do Rio do Futuro. Fonte: Revista Manchete - Edição especial, abril 1965, apud NOBRE, 2008, p. 272. 


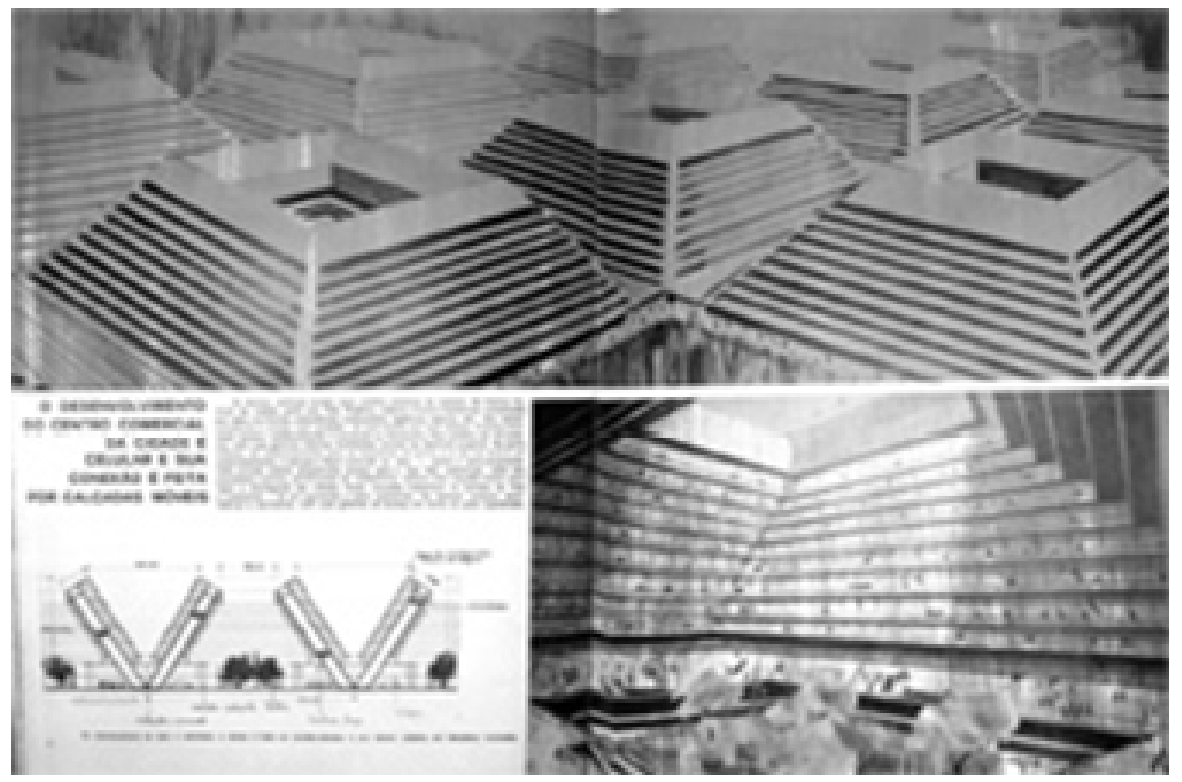

Figura 46: Rio do Futuro - 1965

Fonte: Revista Manchete - Edição

especial, abril 1965, apud NOBRE, 2008, p. 274. 

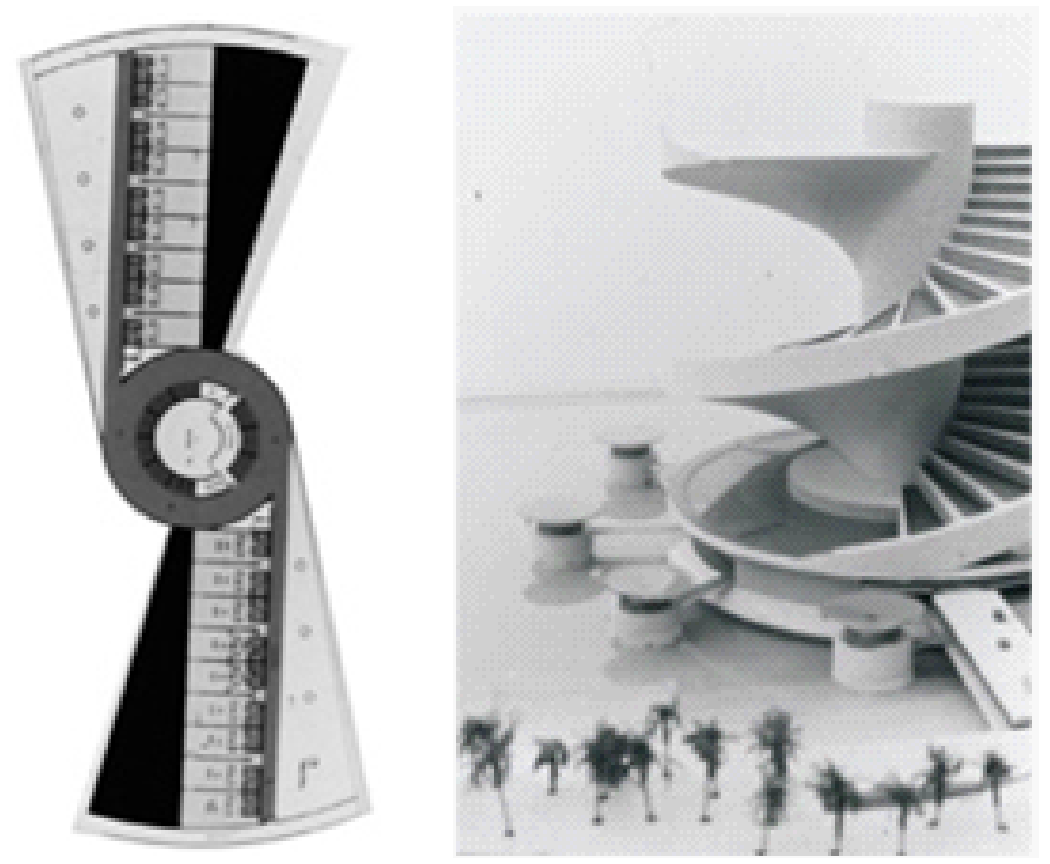

Figura 47: Sérgio Bernardes, Hotel Tropical (Recife) - 1968. Fonte: Revista Manchete - Edição especial, abril 1965, apud NOBRE, 2008, p. 277. 
de Megaestruturas, Cibernética e Cápsulas. No entanto, não há notícias sobre aprofundamentos na temática ou investimentos em projetos de diferentes arquitetos brasileiros que tratem sobre o mesmo assunto, sendo passíveis de uma nova verificação em pesquisas posteriores. 


\subsection{Considerações}

O habitat entendido como as Megaestruturas Espaciais idealizadas pelo Grupo de Estudos da Arquitetura Móvel faziam parte de um sistema e todas as funções necessárias e complementares para a sobrevivência eram realizadas no sistema da cidade. As Megaestruturas foram idealizadas para utilizar a tecnologia da construção civil emergente, com controle e planejamento monitorados.

A cidade era vista como um ambiente cibernético, que possuía um controle, transmissão de mensagens e avaliação da ação dentro do processo. Como Friedman declarou, o importante era o processo, o final dependia da dinâmica do processo e não era determinado.

As propostas que Yona Friedman introduziu eram resultantes da necessidade do momento histórico, a década de 1960: de alta demanda por habitações, de valorização da informação e dos paradigmas emergentes de tempo e espaço.

A mobilidade preconizada pelo GEAM e, consequentemente, por Yona Friedman, se referia a princípios projetuais como flexibilidade, agilidade, efemeridade e modificação do ambiente construído. A necessidade de mobilidade estava associada à liberdade do homem e a sua valorização enquanto ser único e visto como um todo.

A Arquitetura Móvel tinha como características essenciais a estrutura aérea ou Megaestruturas sobre a cidade existente. Era local de constituição do ambiente coletivo, a partir de parâmetros idealizados pelos profissionais arquitetos. Nele, valorizava-se o ser humano considerado imprevisível, a utilização de materiais cotidianos e a livre movimentação dos usuários e dos equipamentos existentes. Segundo Banham a metodologia de organização do espaço do habitat foi baseada nos conceitos de Huizinga (2000) através da teoria dos jogos desenvolvida no livro Homo Ludens. A associação que Banham faz entre Friedman e Huizinga 
está no entendimento das atitude do homem que tem o jogo como uma atividade instintiva. Friedman utilizou também o conceito de imprevisibilidade desenvolvido por Heisemberg. Para Friedman, o ser humano era tão imprevisível quanto o comportamento dos elétrons aplicados na teoria da Mecânica Quântica.

O habitat abrigo era visto também como um ambiente propício para a evolução do ser humano, por isso valorizado como ambiente individual. A moradia era configurada de acordo com as necessidades, com mobiliários funcionais que se moviam formando os ambientes indispensáveis ao cotidiano. Essa conformação negava a tripartição entre área social, de senviço e íntima e também previa a existência de novos agrupamentos familiares.

A configuração do habitat desenvolvida por Yona Friedman era determinada por um espaço artificial, construído em uma Megaestrutura sobre a cidade existente, com controle climático e controle da ocupação dos usuários. Baseado sobre regras claras estabelecidas por aquitetos. Os indivíduos seriam atores participativos do processo de construção da cidade. 


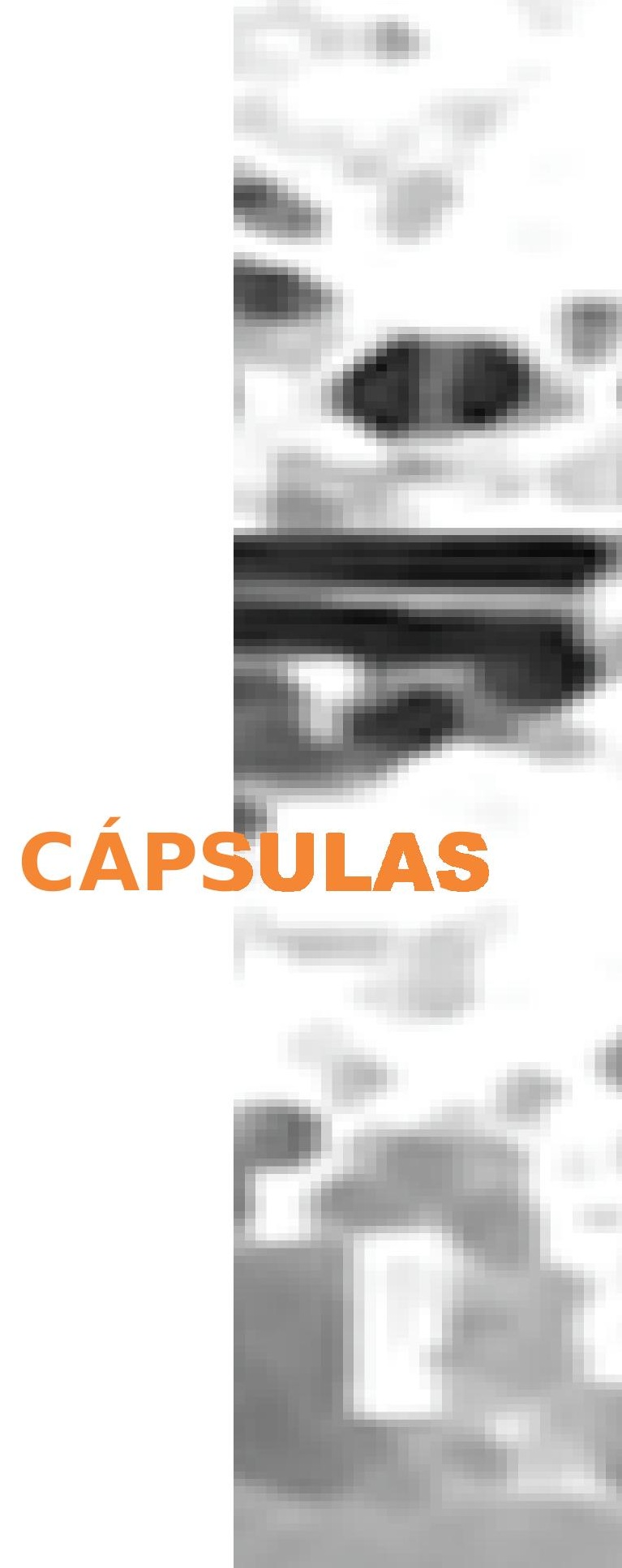


As Cápsulas eram unidades vistas como espaços de habitar que seriam acopladas às Megaestruturas. As unidades seriam a parte do sistema de habitat da cidade que cumpriria a função de habitação.

Este capítulo discute a proposta das cápsulas como espaço de habitar dos anos 1960 através do exemplo das produções teóricas e projetuais do arquiteto japonês Kisho Kurokawa. Além disso expõe as influências que fizeram parte da carreira desse arquiteto, realiza uma retrospectiva histórica das habitações e dos modos de vida japoneses. Descreve a espacialidade e o processo produtivo das cápsulas e, finalmente, realiza um paralelo com Brasil na mesma época.

A conquista do espaço pelo homem foi marcada inicialmente com o lançamento do Sputnik da URSS em 1957. Três anos depois, o astronauta soviético Yuri Alekseievitch Gagarin completou uma volta ao redor da Terra em uma nave espacial. No final da década de 1960, o norte-americano Neil Armstrong pisou no solo da lua com sua bota especial. Esses acontecimentos concretizaram a ideia de que o homem era capaz de viver em um ambiente mínimo como a cápsula, dentro de um sistema fechado autônomo em que eram supridas todas as suas necessidades (CDCC, s/d).

As cápsulas como ambiente habitável surgiram em publicações próximas a 1950 criadas por cientistas que investigavam o espaço com seus equipamentos. A exploração do ambiente submarino e espacial representava para os países desenvolvidos a liderança nas pesquisas de ponta.

A revista Architectural Design, de fevereiro de 1967, publicou vários artigos sobre cápsulas espaciais e submarinas e trazia exemplos de abrigos para esses locais. As manchetes faziam referência às pesquisas envolvidas na conquista do espaço e que elas seriam uma das chaves para o progresso científico e tecnológico. As cápsulas ou naves submarinas eram vistas como um veículo microplanetário, com proteção, coletores e transformadores de energia, sistema ecológico fechado, 


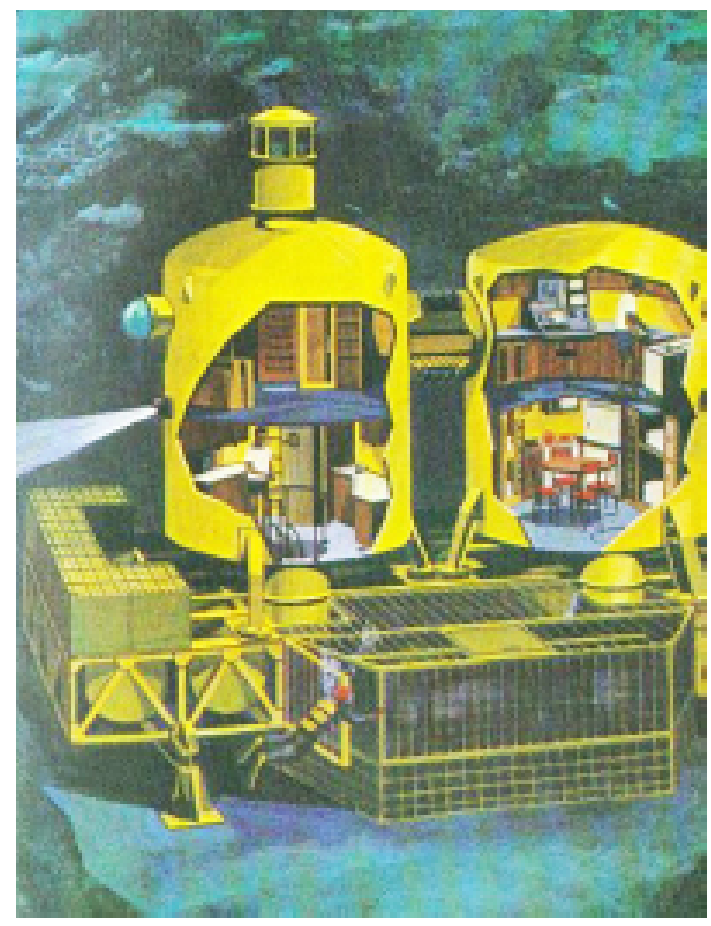

Figura 48: Operação "Tectile, a 15 $m$ de profundidade llhas Virgens. Fonte: (ROSCOE, 1971, p. 110). 
sensores e dispositivos de comunicação. As máquinas eram extensões do homem em estado de simbiose entre homem e máquina.

Montaner no livro 'Depois do movimento moderno: Arquitetura da segunda metade do século XX", de 1995, comentou que em alguns países desenvolvidos como Inglaterra, Estados Unidos, J apão e Alemanha, surgiram propostas com "espírito pioneiro e otimista tecnológico" (MONTANER, 1995. p. 112) em um período de prosperidade, desenvolvimento e crescimento. A chegada do homem à lua teve reflexos nas propostas arquitetônicas como, por exemplo, a vontade de construir cidades sobre o mar e no espaço cósmico. Os novos materiais derivados metálicos e plásticos foram utilizados em peças pré-fabricadas. A arquitetura também passou a ser vista como um objeto fabril e de consumo de massas, com o detalhamento específico das partes produzidas individualmente.

As cápsulas modificaram o modo de ver a autonomia do homem com a máquina, com um espaço mínimo, com aplicação de alta tecnologia e como um sistema independente. Dessa forma o seu princípio poderia servir para as habitações da década de 1960.

Em um artigo publicado na Architectural Design de 1966, Michel Webb e David Greene diziam que a habitação poderia estar em qualquer local estacionável, desde que tivesse todos os equipamentos necessários para sobreviver com um alto estilo de vida. Eles defendiam que ela era um invólucro comparável a uma roupa que protegia um número maior de pessoas. A unidade habitável de Michel Webb se parecia com containers móveis que podiam se locomover no sentido vertical e horizontal, ao longo da megaestrutura, substituindo elevadores. As unidades de serviços também móveis poderiam se acoplar às unidades de estar (WEBB \& GREENE, 1966, p. 573). As Capsule Homes de Warren Chalk foram desenvolvidas em 1964, e tinham como requisitos proporcionar mobilidade, adaptabilidade, e serem descartáveis. Eram pré-fabricadas industrialmente, possuíam um design 
compacto e eram conectáveis a outra estrutura. Além disso os componentes eram intercambiáveis de acordo com a necessidade dos habitantes (DESIGN MUSEUM, 2007).

As cápsulas como tipologias arquitetônicas foram largamente discutidas pelo grupo inglês Archigram. Em um artigo publicado na Architectural Designno. 39 de julho de 1969, as cápsulas foram defendidas por Chris Dawson e Alan Stanton ${ }^{1}$ como uma nova alternativa para viver. Nesse artigo, eles descreviam as cápsulas ou abrigos como um objeto suporte do corpo, uma extensão física e mental do homem, com um sofisticado sistema de comunicação e instalações com diversas possibilidades para alimentação, acondicionamento do ar ou higiene. Uma "unidade módulo" adequada à função do tempo e local, com possibilidade de substituir ou acoplar componentes em locais como postos de combustível ou supermercados, podendo ser estacionada em estruturas de diversos andares. A cápsula teria a capacidade de controle, armazenamento de informações e comunicação de acordo com cada situação e possibilidade (DAWSON \& STANTON, 1969. p. 374). Observa-se que os autores relacionavam um objeto com dimensões mínimas, um sistema de comunicação, produzido industrialmente, capaz de se modificar de acordo com o uso e que cumpria as necessidades básicas de sobrevivência.

Para Montaner, o grupo Archigram tinha propostas pertencentes ao mundo ilusório e próprias dos sonhos tecnológicos, afirma que:

[...] As propostas do Archigram estão baseadas na identificação da liberdade de escolha com capacidade de consumo de todo tipo de produtos. Inclusive a própria arquitetura se converte em kit, elemento substituível, peça transportável (MONTANER, 1995. p. 113).

1 Chris Dawson e Alan Stanton foram colaboradores da Archigram Magazine issue no. 9 foram responsáveis pelo grupo Chrysalis no Departamento de Desenho Urbano em Los Angeles (UCLA) como pós-graduandos. Desenharam e instalaram uma variedade de instalações temporárias e infláveis utilizando materiais da época. Ambas trabalharam como colaboradores no Museu Ponpidou de Paris, junto com Renzo Piano e Richard Rogers. Disponível em: <http://archigram.westminster.ac.uk/collaboratorlist. php\#326>. Acesso em 07 set. 2010. 


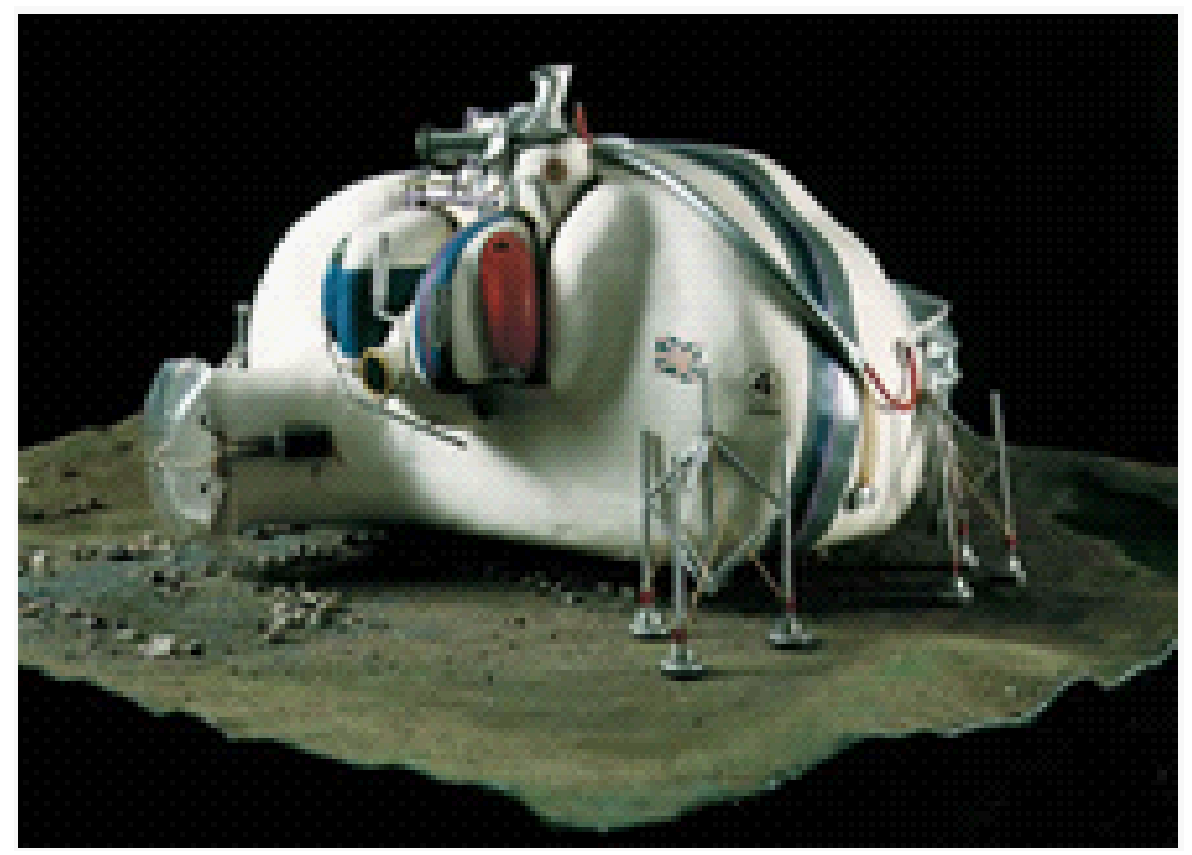

Figura 49: Living Pod (1965)

David Greene. Fonte: Disponivel em: বhttp://www. archigram.net/ projects_pages/living_pod.html>. Acesso em: 22 set 2010.Greene. 


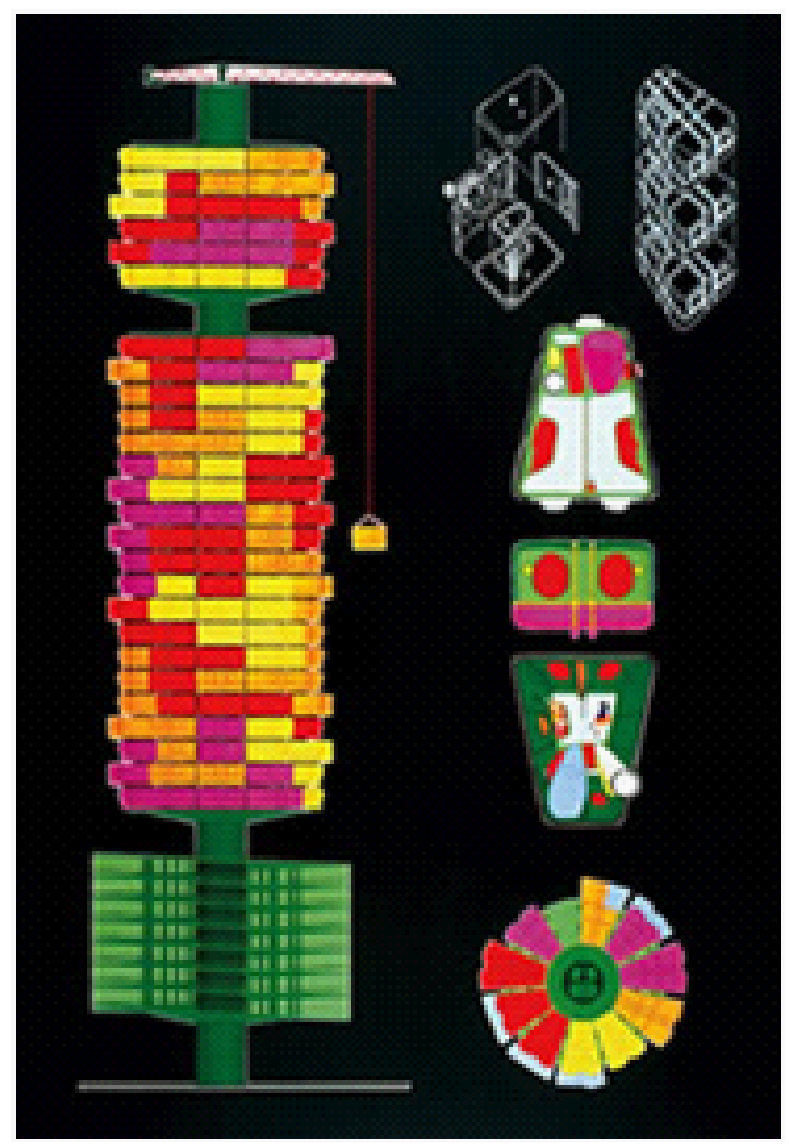

Figura 50: Capsule Homes (1964)

Warren Chalk. Fonte: Disponivel

em: «tttp://www. archigram.net/

projects_pages/capsule_homes_4.

$\mathrm{html}>$. Ačesso em: 22 set 2010. 


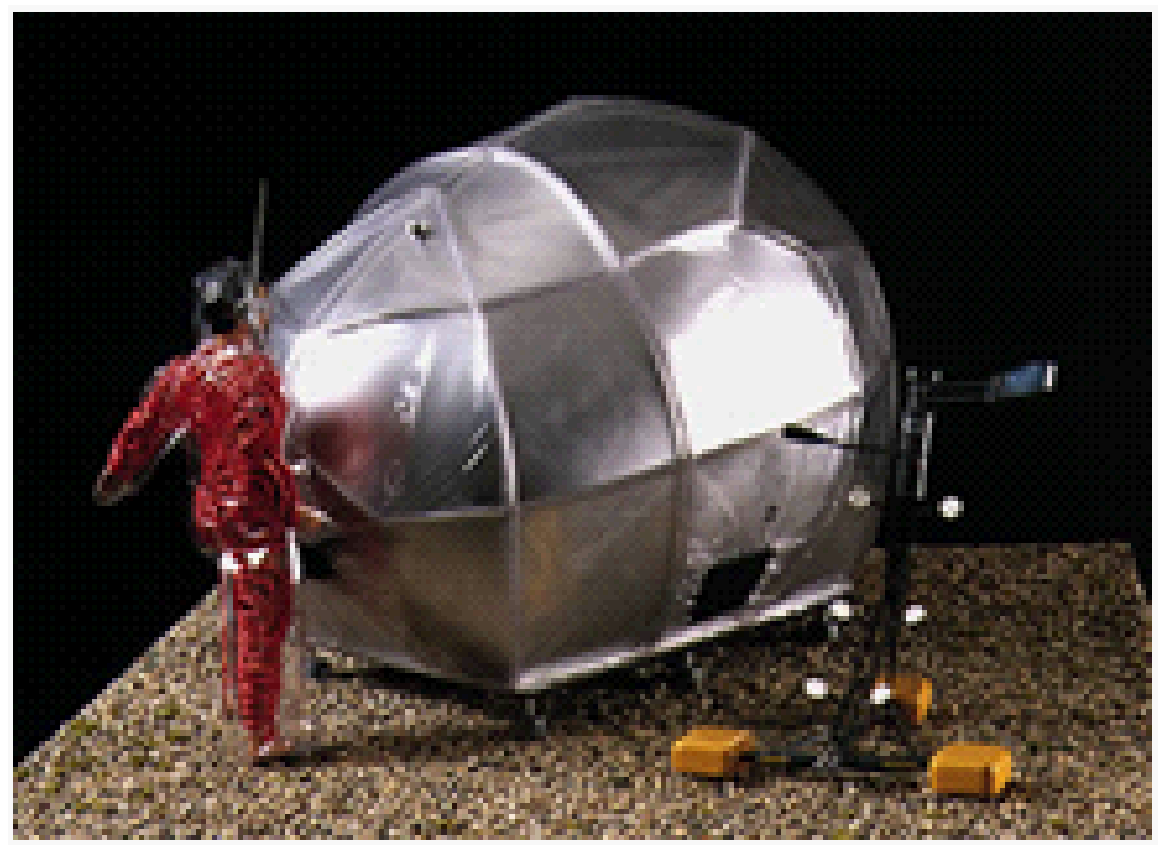

Figura 51: Cushicle (1966-1968) Mike Webb. Fonte: Disponivel em: <http://www.archigram.net/ projects_pages/cuishicle_3.html> Acesso em: 22 set 2010. 
De acordo com a pesquisa realizada nas revistas japonesas, as cápsulas e os conceitos desenvolvidos na Europa e no J apão foram resultado das correntes ideológicas que estavam eclodindo na década de 1960. Traziam a ideia de um homem que poderia estar em qualquer lugar junto ao seu habitat - cápsula. As cápsulas eram entendidas como extensão do corpo e poderiam ser acopladas ou plugadas às infraestruturas ou megaestruturas. As Cápsulas se referem à ideia de envoltório ou invólucro, com unidades mínimas. Deveriam ser produzidas industrialmente em partes separadas, com a possibilidade de serem reconfiguráveis e, possuíam uma relação complementar com a cidade e com a estrutura que as acolhiam.

As cápsulas eram consideradas componentes de habitar. As diversas funções necessárias para o cotidiano deveriam ser complementadas por outros equipamentos da cidade e da megaestrutrura, formando um sistema interconectado.

\subsection{Contextualização do habitar japonês}

As habitações japonesas foram construídas em pequenos espaços desde os tempos remotos. Uma breve análise histórica das habitações urbanas é importante para a compreensão da assimilação das cápsulas nessa sociedade, por esse motivo, esse ítem se propõe a contextualizar o terrítório através do desenvolvimento das moradias no decorrer da história japonesa.

O J apão é um país em extensão territorial equivalente ao estado de São Paulo, formado por um arquipélago montanhoso e com muitas florestas. A ocorrência de terremotos e tufões é frequente, pois se encontra em região de encontro de placas tectônicas. O clima é definido por quatro estações bem demarcadas. O verão é quente e úmido, no inverno as temperaturas ficam em torno de zero graus na maior 
parte do país. A constituição da população é homogênea, formada originalmente por povos Ainu, mongóis, e povos do sul asiático (SEIROKU, 1967, p.11).

As primeiras casas urbanas tiveram origem no período Heian² (Kyoto 794-1185) até a Restauração Meiji, e essas moradias urbanas que eram principalmente de comerciantes e artesãos possuíam duas características:

A primeira era a formação das casas ao longo da rua ${ }^{3}$. Os limites frontais da testada das casas eram limitados e geralmente destinados à área de comércio ou negócios. Em contradição, os espaços posteriores eram profundos e possuíam pequenos quartos alugados a funcionários ou pessoas mais pobres. Os sanitários e o ponto de água eram comuns para as casas do fundo (NISHIYAMA, 1963), como mostram as figuras 52 a 56 .

A segunda característica comum comentada por Nishiyama (1963), era o espaço chamado toriniwa. Consistia em uma passagem em nível inferior que se estendia da rua até as casas dos fundos. Essa parte em desnível era utilizada para trabalhar e cozinhar. Inicialmente era uma área de uso semipúblico acessada pelos outros moradores. Era escura e de uso essencialmente feminino; ilustrada na figura 56.

Segundo Nishiyama (1963) a parte de piso elevado que posteriormente foi coberta com as esteiras de tatamiera utilizada como área de estar, tinha de um a três cômodos (fig 57). A sala anterior (misenoma) era utilizada como loja. A sala atrás era íntima (nakanoma), utilizada para receber visitas e para refeições e a sala posterior (okunoma) utilizada para dormir. Ambas poderiam ser aumentadas com

2 A história do Japão é dividia em eras, as fases anteriores ao peíodo Edo, tiveram forte influencia chinesa e de outros países como Portugal. O período Edo é reconhecido pelo fechamenbto do Japão para os países estrangeiros. A reabertura do país data da Era Meiji, paralela a Revolução Industrial e a necessidade de modernização do Japão

Era J omom (10.000 AC - 300 AC), Era Yayoi (300AC-300DC), Era Kofun (300-645), Era Asuka (645-710, Era Nara (710-794), _Era Heian (Kyoto - 794-1185), Era Kamakura (1185-1333), Era Muromachi (13331568), Era Edo (1603-1867 atual Tokyo), Era Meiji (1868-1912), Era Taishô (1912-1926), Era Showa (19261989) e Era Heisei 1989- )..

3 Como mostrado na explicação de Fumihiko Maki, fig 67. 


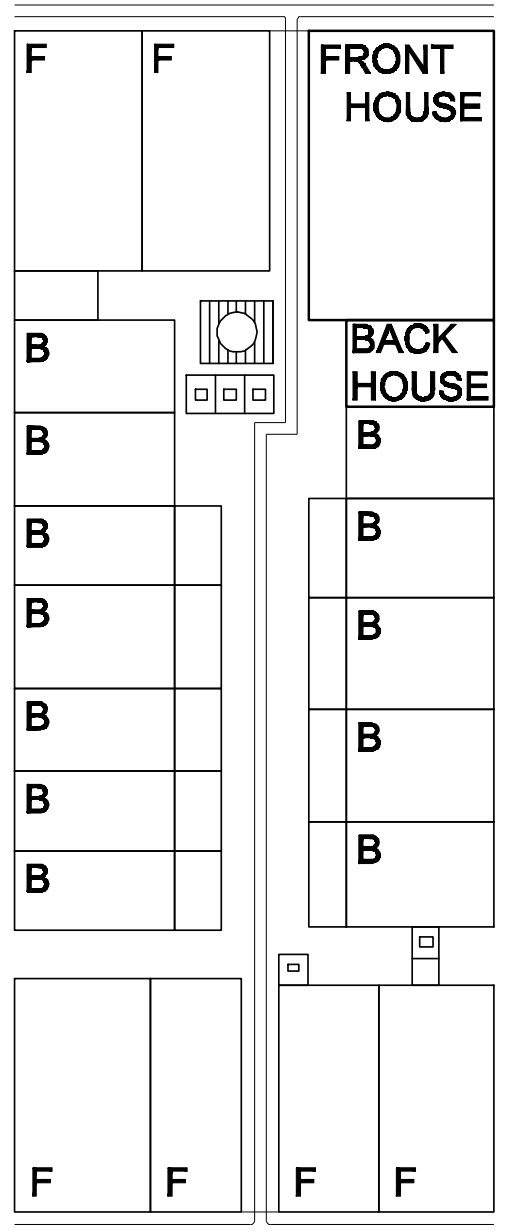

Figura 52: Conformação das casas no período Edo. Fonte: (NISHIYAMA, 1963, p. 29).

Reprodução do desenho Camila Borghezan 


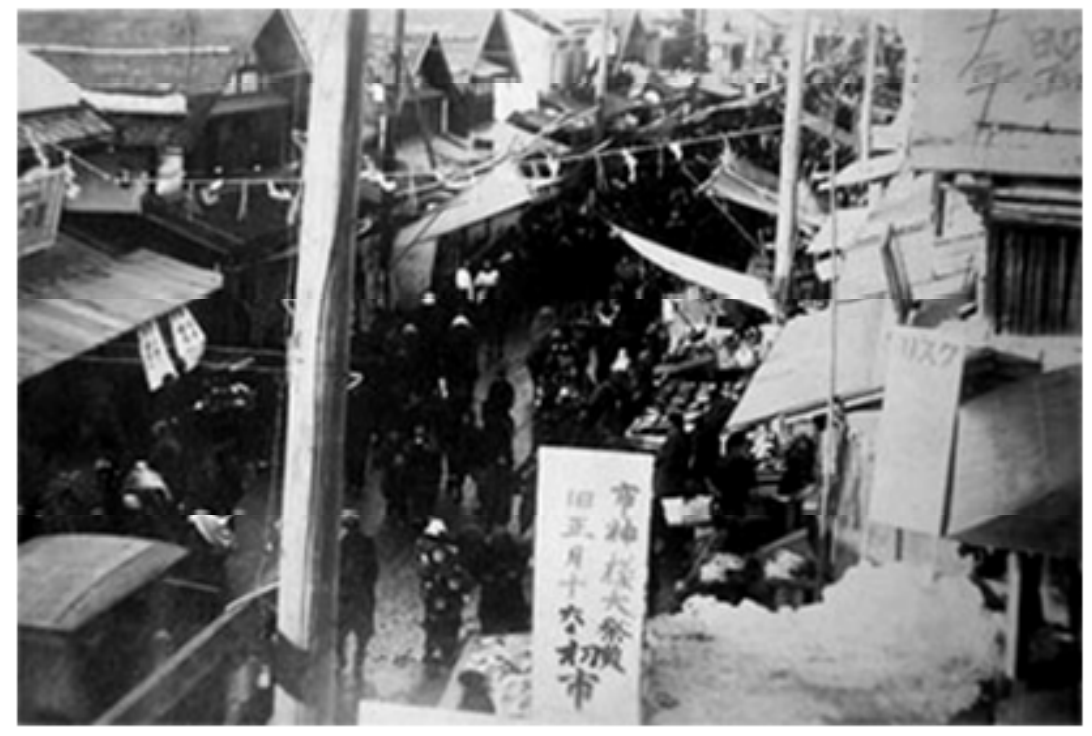

Figura 53: Cidade: rua do

Comércio. Fonte: arquivo pessoal. 


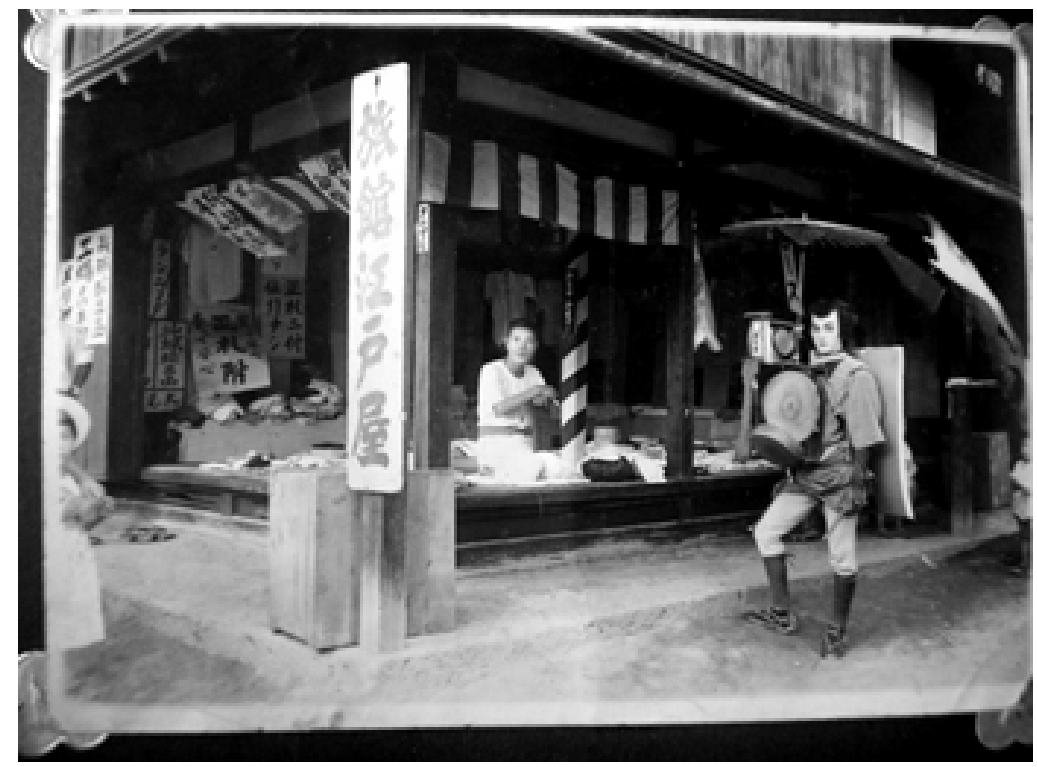

Figura 54: Mercadores Era Taishô - espaço comercial voltado para a rua. Fonte: acervo pessoal. 


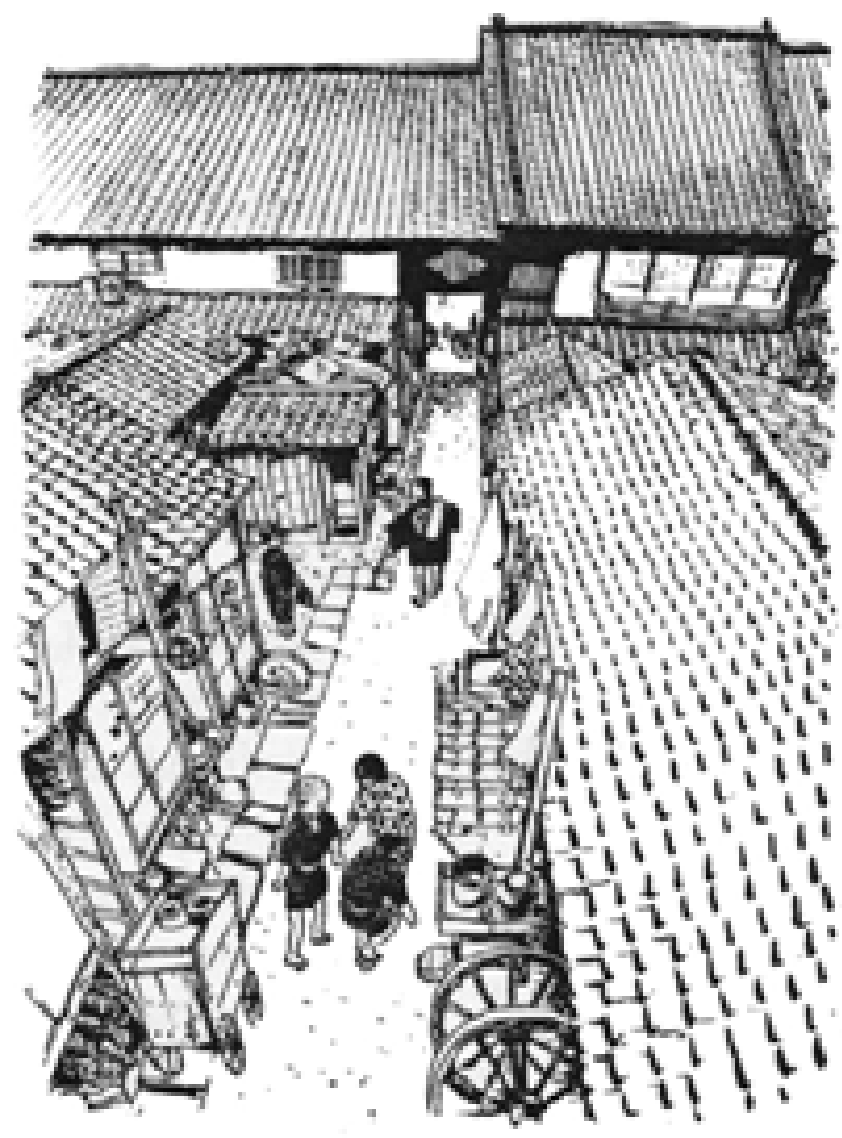

Figura 55: Corredor interno dos quartos locados. Fonte: (NISHIYAMA, 1963, p. 29). 


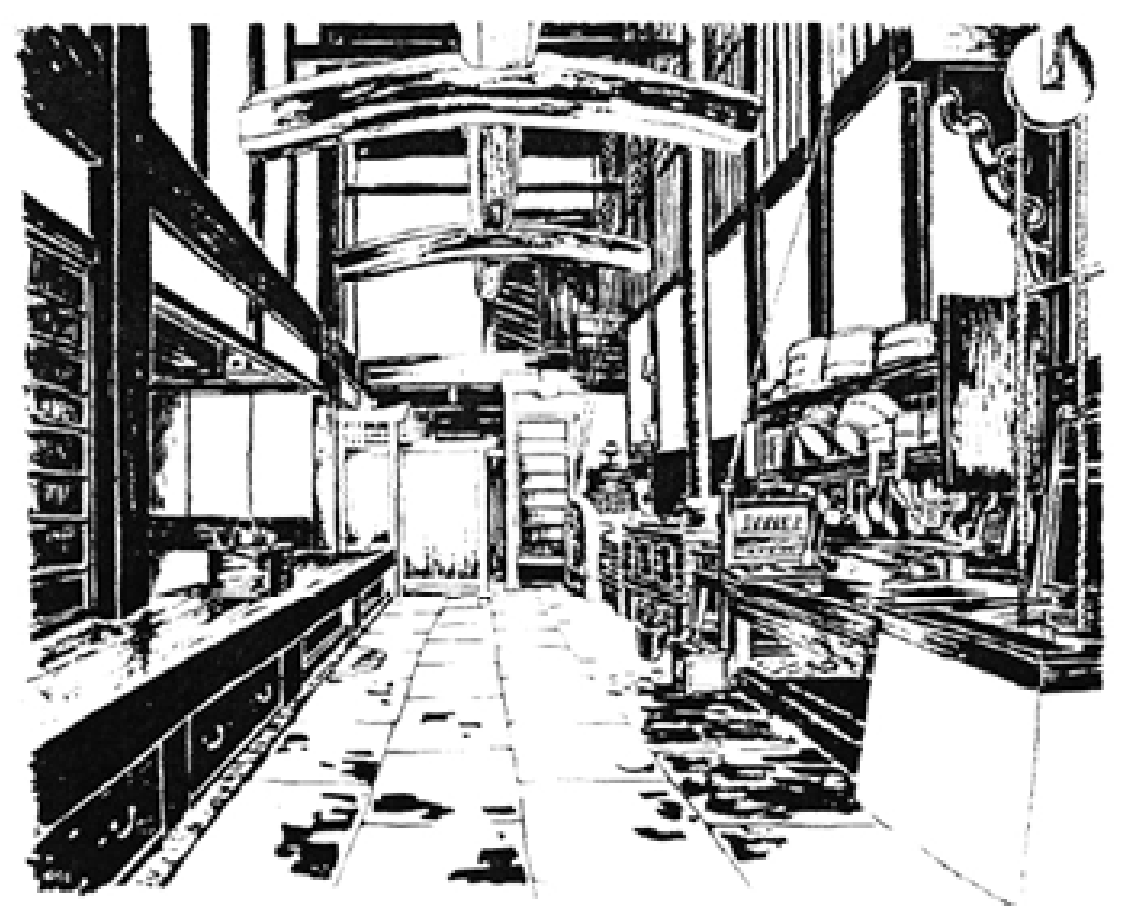

Figura 56: Área de cocção de uma casa urbana (toriniwa) antes da era do imperador Meiji (1868-

1912). Fonte: (NISHIYAMA, 1963, p.

29). 
a retirada dos painéis móveis e assumir diferentes utilizações, como dormir, servir, alimentar-se ou conversar. Era habitual a família dormir no mesmo ambiente. Nesse período as vontades dos moradores estavam subordinadas ao dono da casa, que tinha poder patriarcal sobre a família e os funcionários que estavam aos seus cuidados. A entrada ao lado da área comercial era comum ao proprietário e às casas dos fundos.

De acordo com o mesmo estudioso sobre a evolução das moradias japonesa, com a abertura do país a partir da Restauração Meiji (1868), as casas sofreram modificações gradativas com a disseminação dos novos modos de vida ocidentais. E após as duas grandes guerras mundiais, os indivíduos passaram a exigir quartos individualizados, a sala foi difundida, o quarto de hóspedes tornou-se a sala de recreação da família, valorizaram-se os mobiliários do tipo ocidental, tais como sofás, cadeiras, mesas e camas, os ambientes passaram a ser distinguidos pela função e não mais de acordo com a hierarquia familiar (fig. 58) (NISHIYAMA, 1963. p. 30).

Em 1941 foi estabelecido o sistema "DK" (dinning/kitchen), que considerava o ambiente de comer e cozinhar unificados. Assim, o J apão passou a construir residências 2DK (dois quartos mais dinning/kitchen) ou 3DK (três quartos mais dinning/kitchen). Essa tipologia tinha como pano de fundo a economia de espaço entre cozinha e jantar além da separação da área de dormir dos jovens, velhos, casais e solteiros (fig. 61 e 62).

Nesse período também foram construídas casas de concreto em caráter experimental. Além disso projetos habitacionais incluindo parques, lojas, escolas e hospitais foram erguidos em larga escala.

Na década de 1950, o governo japonês fez pesquisas e a partir dos resultados estipulou em $10 \mathrm{~m}^{2}$ a área ideal para uma pessoa viver. Em um levantamento realizado em 1955, o espaço verificado era de 3,5 tatamis ou 5,6 $\mathrm{m}^{2}$ por pessoa, o 


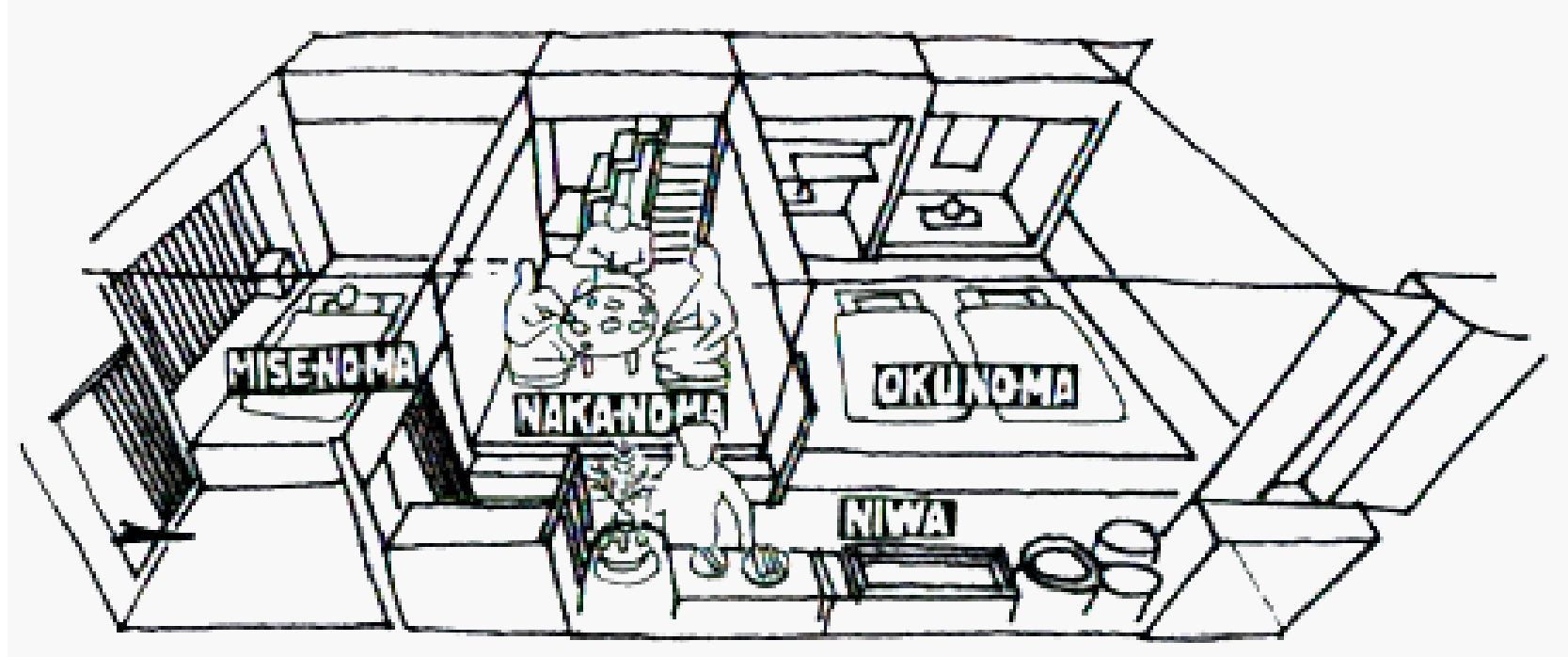

Figura 57: Casa frontal, (da

esquerda para a direita) comércio,

sala íntima e sala posterior. Fonte:

(NISHIYAMA, 1963, p. 29). 


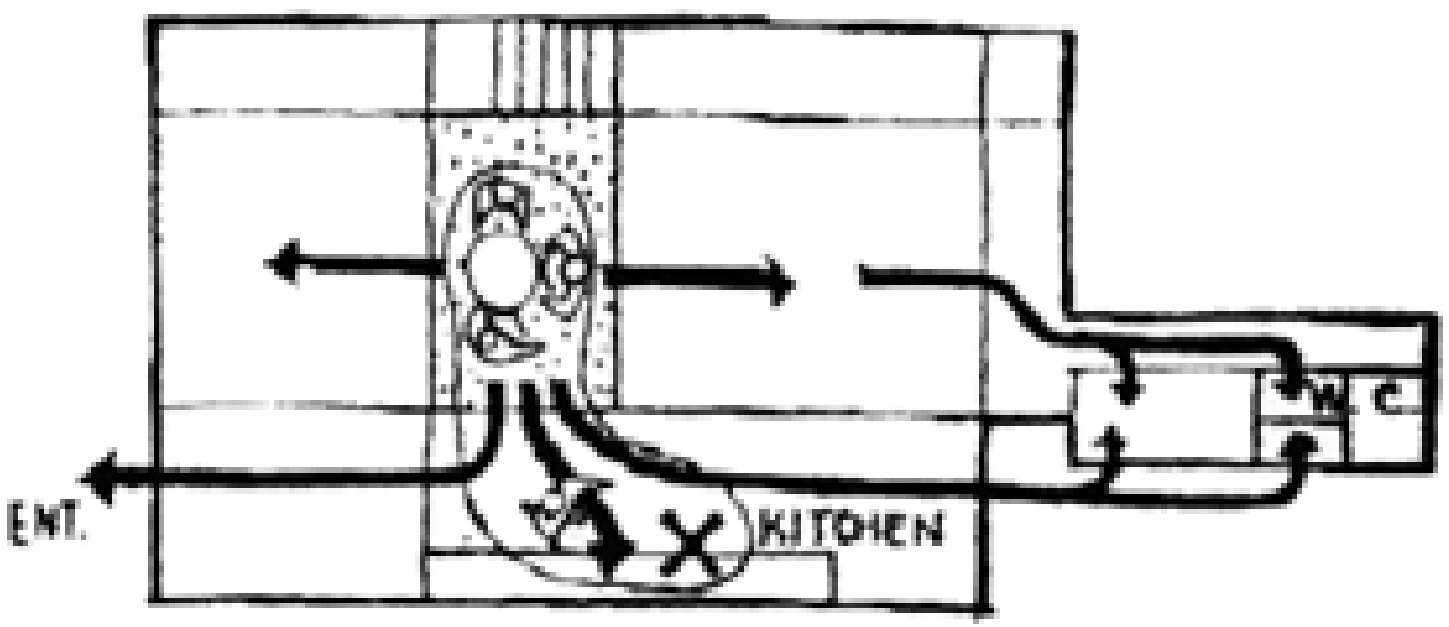

Figura 58: Planta casa tradicional japonesa da figura ao lado. Fonte: (NISHIYAMA, 1963, p. 29). 


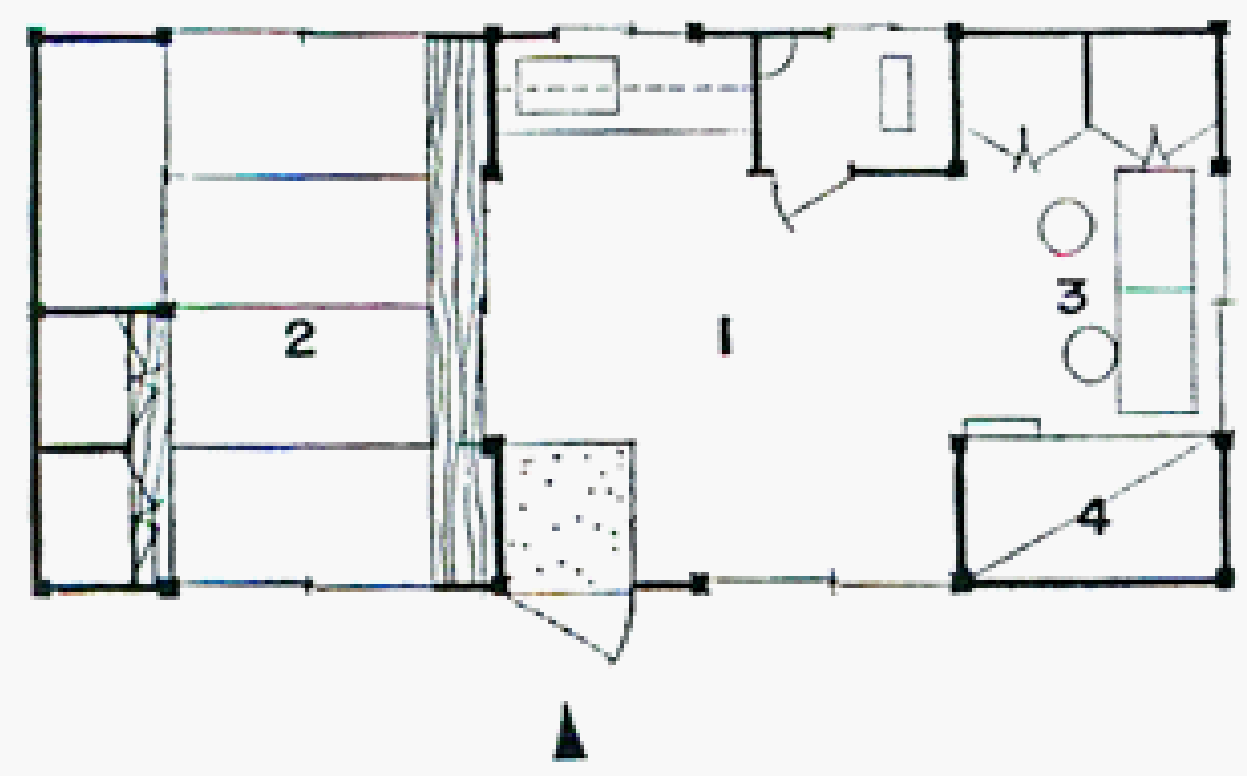

Figura 59: Casa mínima. 1. Estar e cozinha, 2. Zashiki (quarto), 3. Area de estudo. Fonte: (NISHIYAMA, 1963, p. 30). 


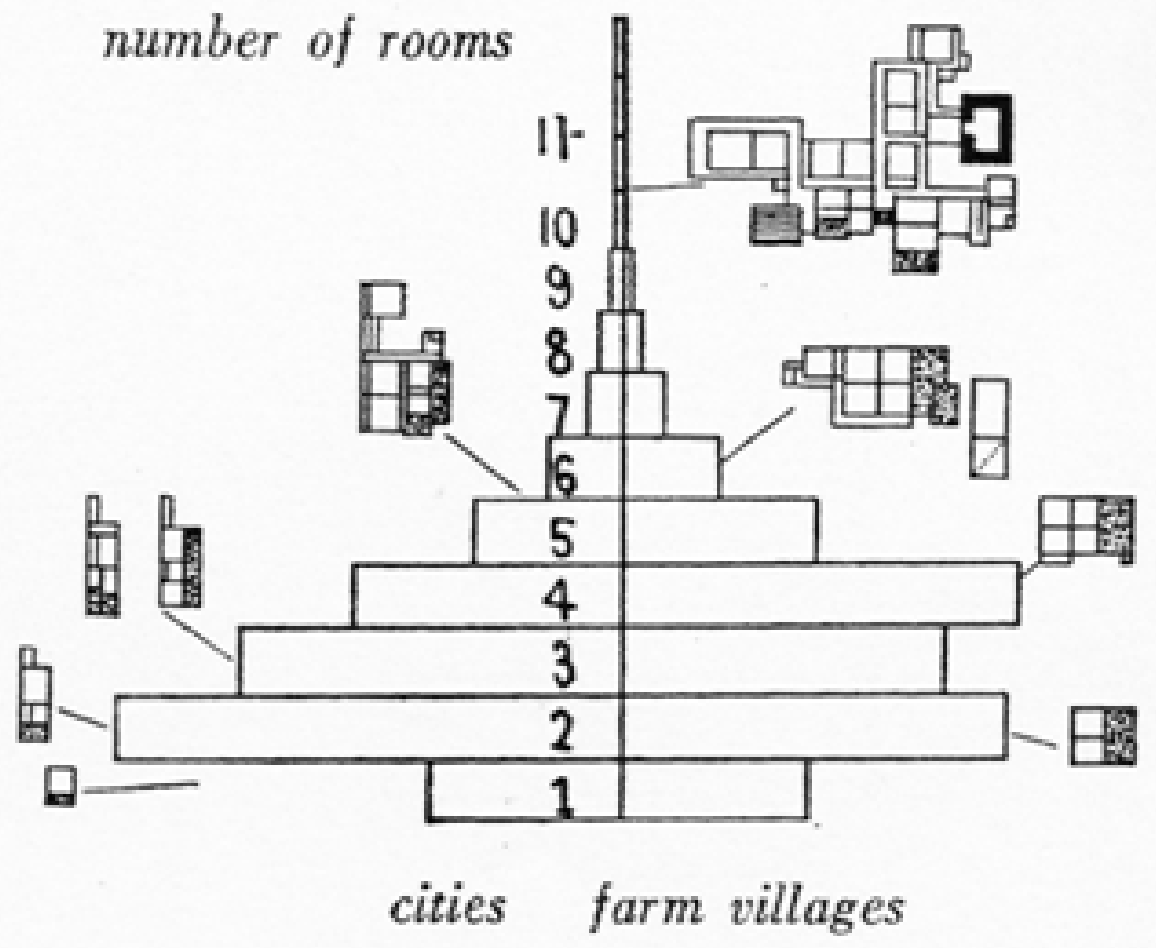

Figura 60: Distribuição do número de cômodos das habitações da cidade e da área rural em 1930. Fonte: (NISHIYAMA, 1963, p. 30). 


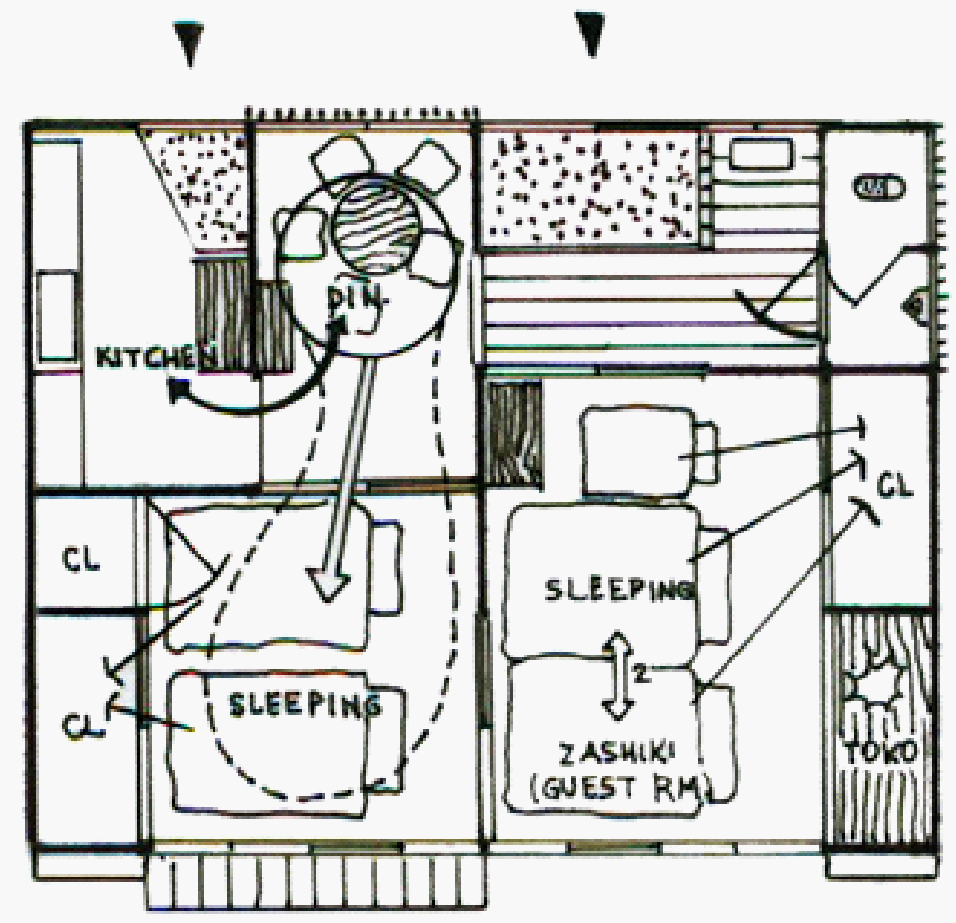

Figura 61: Planta 2DK dividia em área de dormir e área de comer.

Fonte: (NISHIYAMA, 1963, p. 31). 
que significava uma vida em condições precárias (NISHIYAMA, 1963, p. 30).

De acordo com Yoshida (1960), a década de 1950 também significou o ponto de mudança entre o J apão pós-guerra e o início da explosão da construção civil. No campo das residências, a cozinha que era construída com orientação para o norte, em local frio e escuro passou para a face sul combinada com o espaço de estare jantar. Simultaneamente, houve um incremento nas instalações, individualização e criação de espaços para o entretenimento da família.

[...] a guerra, destruindo a maioria das habitações do país, criou uma severa escassez de moradias, que tiveram que ser feitas rapidamente e em uma escala mínima de conforto para viver. Como resultado, o local de jantar, a cozinha tornou-se a parte dominante da maioria do planejamento residencial, e a sala de estar, como tal, caiu em vão. $[\ldots]^{4}$ (KOJIRO, 1970. p. 76, tradução nossa).

Nessa configuração de habitação mínima havia um espaço de tatami que era utilizado para toda a família dormir e outra área de cozinha, área de estar da família, estudos e alimentação. A entrada (genkan) possuía um armário e um espaço para tirar os sapatos. Esse costume vinha das casas antigas que tinham tablado elevado onde não se usavam calçados.

A área de armazenagem utilizada para guardar o shikibuton (acolchoado que era colocado sobre o tatami para dormir), o futon e o makurá (cobertor e travesseiro). O armário tinha o mesmo tamanho do módulo do tatami $\left(0,90 \mathrm{~m} \times 1,80 \mathrm{~m}^{5}\right)$, que facilitava o armazenamento por ser um tamanho consideravelmente grande para os padrões ocidentais (fig.61 e 62).

$\mathrm{Na}$ descrição de Morse (1886) as casas japonesas eram subdivididas por painéis

4 Original em inglês: [...] war, by destroying most of the nation's dwellings, created a dire housing shortage, which had to be made up quickly and on a minimal scale of living comfort. As a result, the diningkitchen became the dominant part of most residential planning, and the living room, as such, dropped by the way. [...] (KOJIRO, 1970. p. 76) 5 Medida padrão da região de Kyoto. 


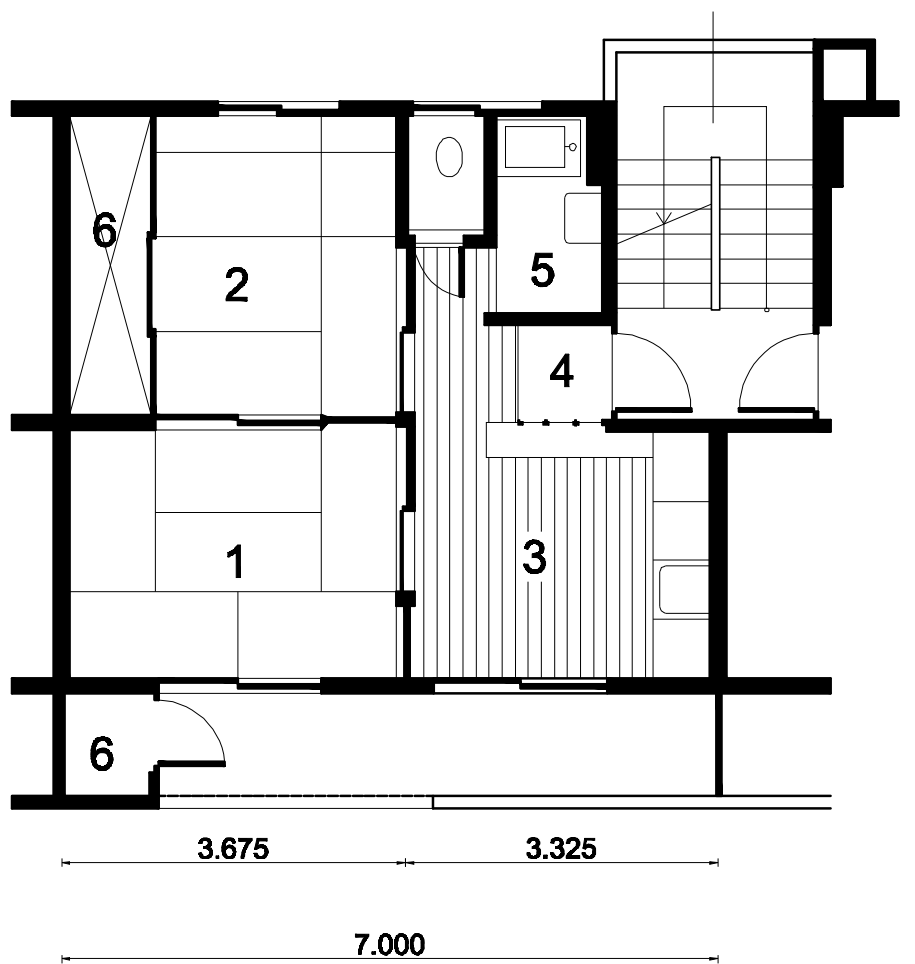

Figura 62: Planta de 47,01 $\mathrm{m}^{2}, 1$. Sala de estar e dormir, 2. Sala de estar e dormir, 3. Cozinhar e comer, 4. Entrada, 5. Banheiro, 6 Armário. Fonte: (NISHIYAMA, 1963, p. 31). Reprodução do desenho: Camila Borghezan 


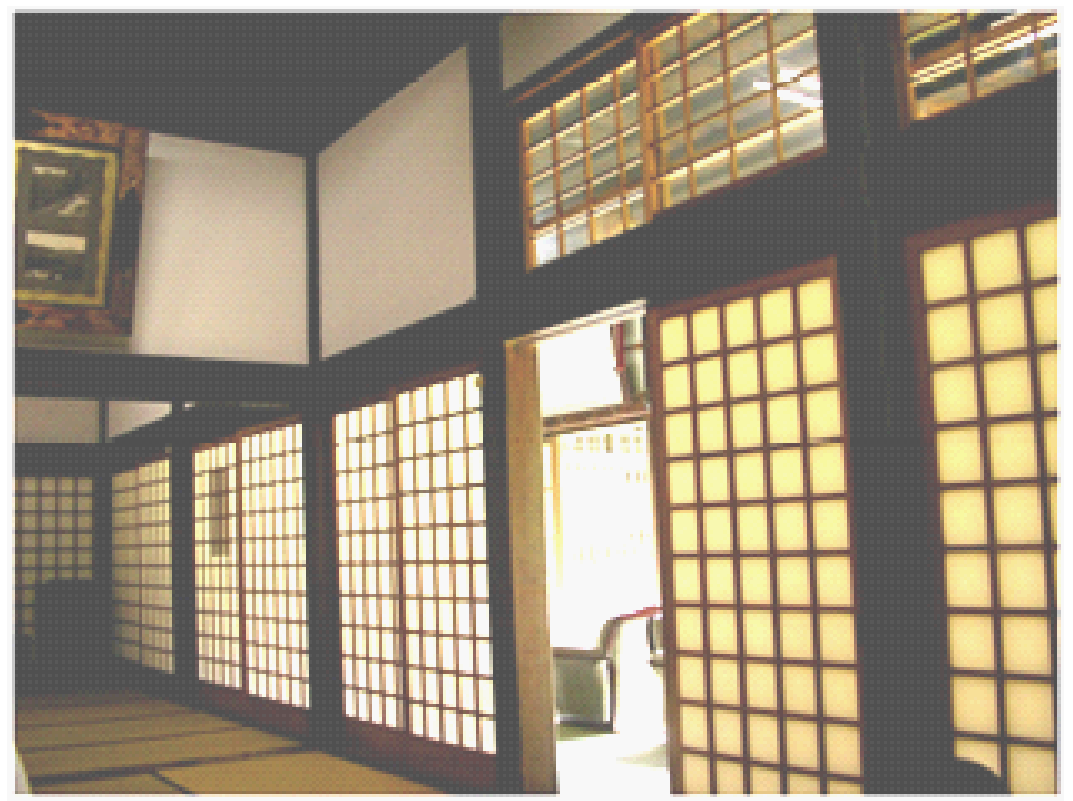

Figura 63-Templo japonês construído com modulação de tatami. Foto- acervo pessoal. 
móveis de $90 \mathrm{~cm}$ por aproximadamente $1,80 \mathrm{~m}$, e painéis de piso também nas mesmas medidas. Nos cantos existiam pilares de madeira que se encaixavam nas vigas e estruturas do telhado. Engel ${ }^{6}$ (1985) explica que os módulos formavam uma grelha que era uma unidade de organização.

Essa grelha modulada a partir do tatami formava uma grande extensão que poderia ser subdivida em pequenos cômodos. Como comenta Kojiro (1964) o povo japonês não fazia distinção entre espaço interior e exterior, considerando que era uma única entidade. $O$ espaço fluía pelas salas que não tinham divisórias laterais ou limites (fig 63). A sensação de segmentação era criada pelos pilares, painéis e espaços de exposição para objetos de arte (KOJ IRO, 1964, p. 61).

A falta de espaço para os japoneses sempre foi questão intrínseca e, portanto, estavam acostumados a utilizar um mesmo ambiente para executar diferentes atividades do cotidiano.

Nesse contexto, após a gradativa ocidentalização desde o período Edo, as casas japonesas sofreram modificações de acordo com os modos de vida. A população mais pobre, que antes morava em vielas, passou para casas com espaços mínimos e com configurações ocidentalizadas; as áreas molhadas, agora com a junção das atividades de jantar, cozinhar e entretenimento estavam geralmente na entrada da casa; o sanitário separado da banheira (ofurô) e da pia possibilitavam a utilização independente. A lavagem de roupas ficava habitualmente junto com a área de banho. A sala de tatami podia ser usada como quarto de dormir, sala de visitas, ou sala de jantar. E o outro quarto normalmente era usado para as crianças.

Com a assimilação dos modos de vida ocidentais, as crianças e os idosos passaram a dormir em quartos separados. As relações de afeto se tornaram mais valorizadas no cotidiano do casal. Apesar disso a mulher ainda hoje ocupa uma posição social discriminada, possui salários inferiores aos homens e raramente

6 Data da primeira edição 1964 
continua a trabalhar após a vinda dos filhos.

O desenvolvimento da moradia japonesa está intimamente ligada a abertura do país ao ocidente. Mostra a assimilação da valorização do núcleo familiar, da separação funcional dos ambientes entre quarto, cozinha e jantar, e preconiza espaços maiores para a acomodação dos indivíduos.

Essa gradativa ocidentalização seria verificada no habitat das cápsulas, os espaços mínimos das casas não seria barreira para a incorporação das células na sociedade japonesa.

\subsection{Influências para a Arquitetura}

O movimento Metabolista foi importante na história recente da arquitetura japonesa e na forma de lidar com o habitat. Em um artigo com o título "Post-Metabolism" escrito por Kazuhiro Ishii e Hiroyuki Suzuki, publicado pela The Japan Architect, v. 247 de outubro e novembro 1977, concretizava o final do metabolismo e citava que, "A década de sessenta no J apão foi o período da arquitetura Metabolista" (ISHII \& SUZUKI, 1977, p. 8).

De acordo com a bibliografia levantada, as influências que foram determinantes para a produção de Kurokawa e para os Metabolistas foram: Kenzo Tange, Buckminster Fuller, o grupo Archigram, e os Smithsons, principalmente com a Casa do Futuro ${ }^{8}$.

Kenzo Tange foi um dos principais representantes do Movimento Moderno no J apão, influenciado diretamente por Walter Gropius, Le Corbusier e Mies van der Rohe ${ }^{9}$. Em um artigo publicado por Kojiro Yuichiro, em 1959, falava sobre a

7 Original em inglês: The decade of the sixties in Japan was a period of architectural Metabolism (ISHII \& SUZUKI, 1977, p. 8).

8 Casa desenvolvida pelo casal Smithson para uma exposição.

9 Tange era amigo de Le Corbusier e participou de varios CIAMs. 
contribuição de Kenzo Tange na arquitetura. Talvez ele tenha sido um dos principais arquitetos a construir com os paradigmas modernos no J apão. Tange vivenciou a crise do Movimento Moderno e a entrada para os conceitos relativos à sociedade da informação reconhecidos depois dos CIAMs.

Conforme a figura 64, Tange foi autor de propostas de habitações em diferentes níveis, semelhantes a degraus, para 25.000 pessoas, que remetem às Megaestruturas. Segundo Mühl (1979), nesse projeto que poderia ser multiplicado em sua extensão, os edifícios eram voltados para uma praça com o centro livre, onde havia locais para esportes, escolas, comércio e escritórios. O projeto Tsoukiji (fig 65) era uma proposta para abrigar 100.000 pessoas. Tinha o formato de grandes pontes foi elaborado com circulação interna e era ligada a autoestradas e metrô. Nos apartamentos para o Teheran, no Irã (fig 66), havia edifícios voltados para o parque, com presença de comércio, estacionamento e lazer. Os 500 apartamentos tinham três ou quatro ambientes formados por paredes portantes que configuravam a estrutura do prédio.

Historicamente, as formações dos espaços coletivos nas cidades japonesas estavam localizadas nas ruas e não havia praças. Como mostra a seguir, as cidades, desde o período Heian (Kyoto, 794-1185), eram organizadas de forma linear (fig 67). Observou-se que, após a abertura do J apão, os conceitos ocidentais de urbanismo foram assimilados gradativamente, como demonstraram as propostas de Tange no desenho de megaestruturas e cidades.

Tange introduziu no J apão elementos geométricos e grandes vãos livres, megaestruturas que incluíam praças e faziam parte de um sistema maior com moradia, equipamentos urbanos e transportes. Mas o respeito e a história japonesa estavam presentes em seu trabalho.

Outra referência para os Metabolistas e especificamente para Kurokawa era Buckminster Fuller (1895-1983) nascido em Massachusetts. Ele era autodidata 

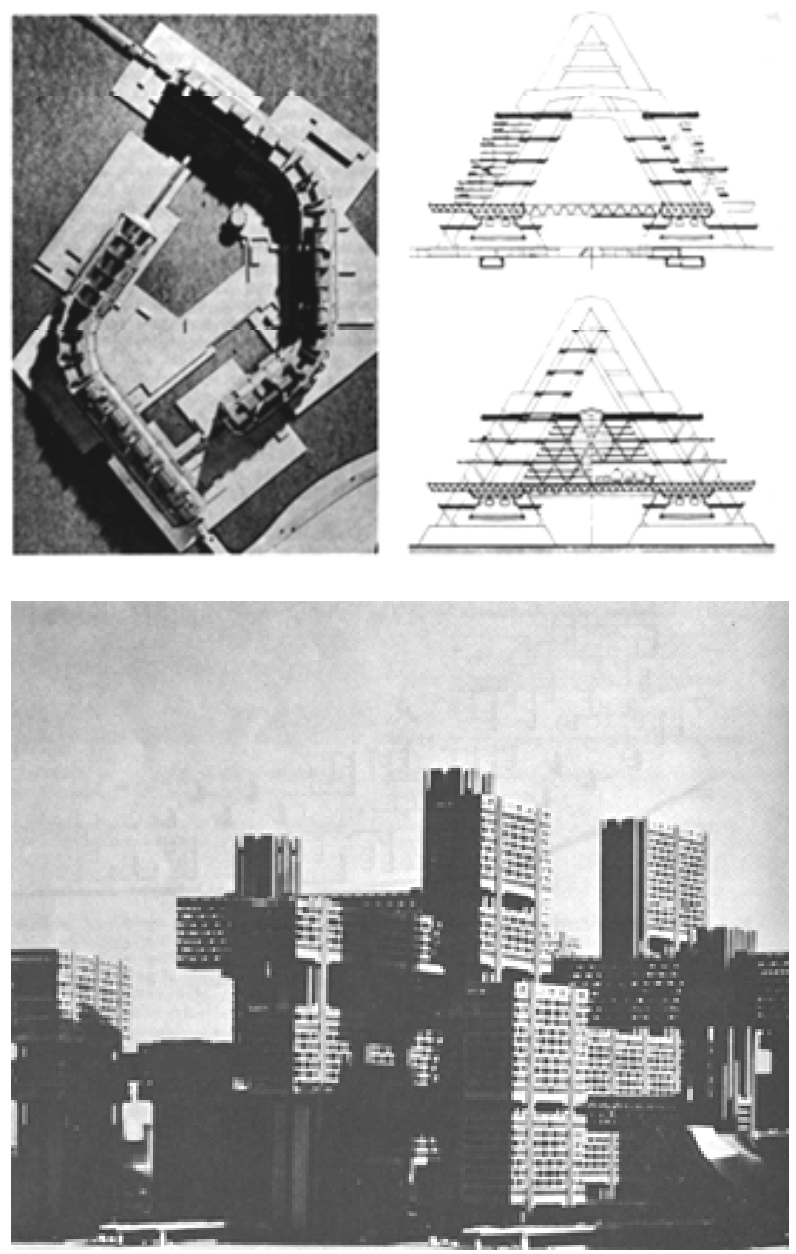

Figura 64: Maquete e corte do prédio para unidade de habitação. Desenvolvido no Massachusetts Institute of Technology - Cambridge 1959-60. Fonte: (MÜHL, 1979. p. 11). Figura 65: Estudo sobre a disposição do quarteirão de Tsoukiji (1960-64) . Fonte: (MÜHL, 1979. p. 15). 


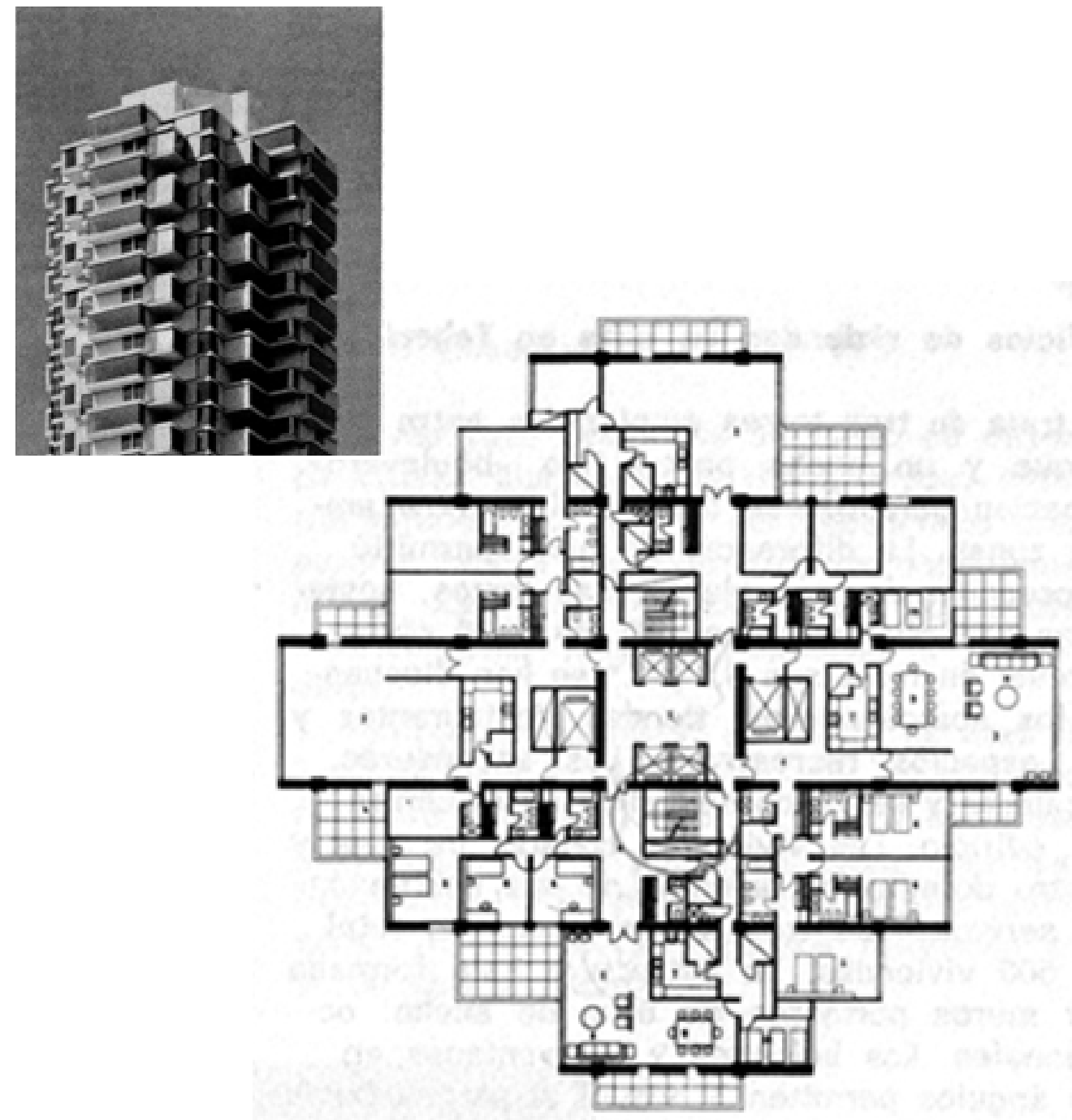

Figura 66: Arranha-céus para

apartamentos em Tehera s/d. Fonte:

(MÜHL, 1979. p. 26). 


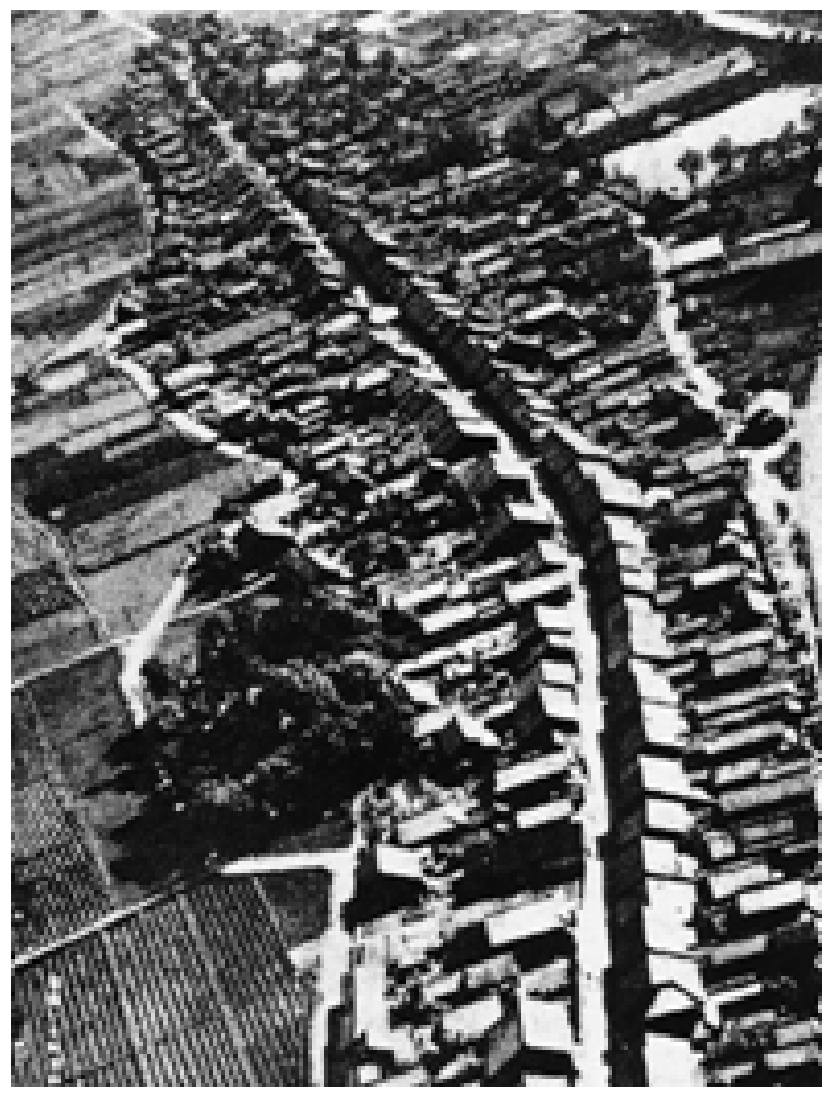

Figura 67: Vila agrária. Fonte: (MAKI, 1964, p. 263). 
e tinha conhecimento nas áreas da construção civil, mecânica, aerodinâmica e outros. Produziu a série Dymaxion que vem de dinâmico (Dy), máximo (Max) e tensão (Ion) e que incluía um carro, um avião e uma casa. Fuller foi influência para toda uma geração de arquitetos japoneses, incluindo Kurokawa, como cita o historiador Kojiro (1959) em um artigo sobre a história da arquitetura japonesa, as tecnologias e o desenvolvimento:

[...] Encontra-se um número de jovens arquitetos japoneses que, sob a influência de Fuller e Wachsmann ${ }^{10}$, procuram se expressar em termos de grandes espaços criados com pequenas peças padronizadas [...] ${ }^{11}$ (KOJIRO, 1959, p.115, tradução nossa).

Segundo Banham (1979), Fuller utilizou-se da tecnologia naval e aeronáutica para criar projetos diferenciados frente a seus contemporâneos que viviam na era industrial e produziam uma arquitetura discutindo somente questões formais da era industrial.

Em 1927, Buckminster Fuller propôs a construção da Casa Dymaxion, projeto de uma casa em alumínio. Tinha uma base hexagonal estruturada sobre um eixo central e suspensa por cabos, possuía os serviços mecânicos de aquecimento, luz, música, limpeza, alimentação e ventilação ligados à coluna central. Os fechamentos eram feitos de plástico duplo com capacidades diferentes de transparência e iluminação. Era uma casa de baixo custo, como Banham descreve:

As qualidades formais deste projeto não são notáveis, a não ser na combinação com os métodos de estruturação e de planejamento envolvidos. A estrutura [...] é uma adaptação da metodologia de metais leves empregados na construção aérea da época (BANHAM, 1979. p. 509).

10 Konrad Wachsmann, elaborou junto com Walter Gropius o General Panel System, um elemento préfabricado para habitação que poderia ser utilizado em qualquer tipo de construção. (BRUNA, 1976, p. 62) 11 Original em inglês: One finds a number of Young Japanese architects who, under the influence of Fuller and Wachsmann, are seeking to express themselves in terms of large ]spaces created with small standardized parts, [...] (KOJIRO, 1959.p.115) 


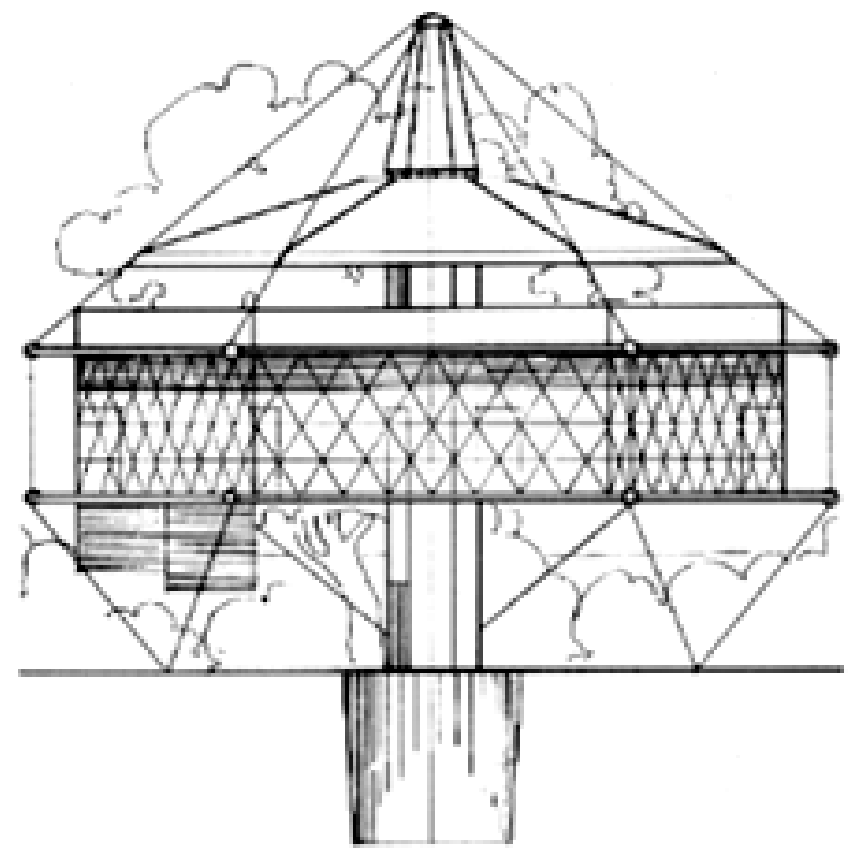

Figura 68: Dymaxion House. Fonte: Disponível em: বhttp://www.bfi. org/ >Acesso em: 18 set 2010. 


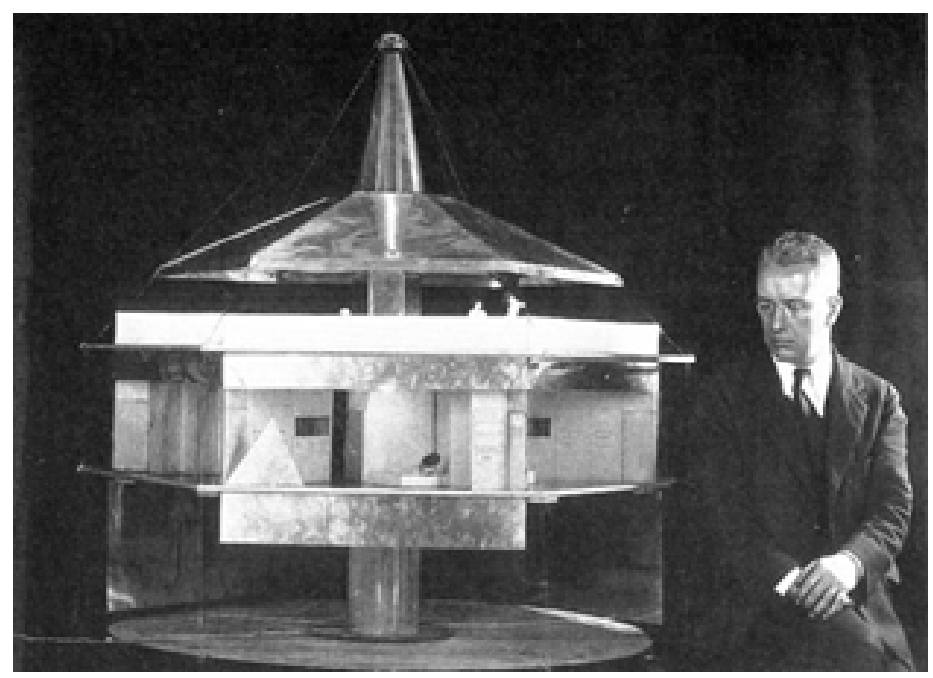

Figura 69: Foto Maquete

Dymaxion House. (1927-1930).

Fonte: Disponível em: ‘http://

greatdesigners. wordpress.

com/2008/11/08/great- designer-r-

buckminster-fuller $>$ Acesso em: 18

set 2010 . 


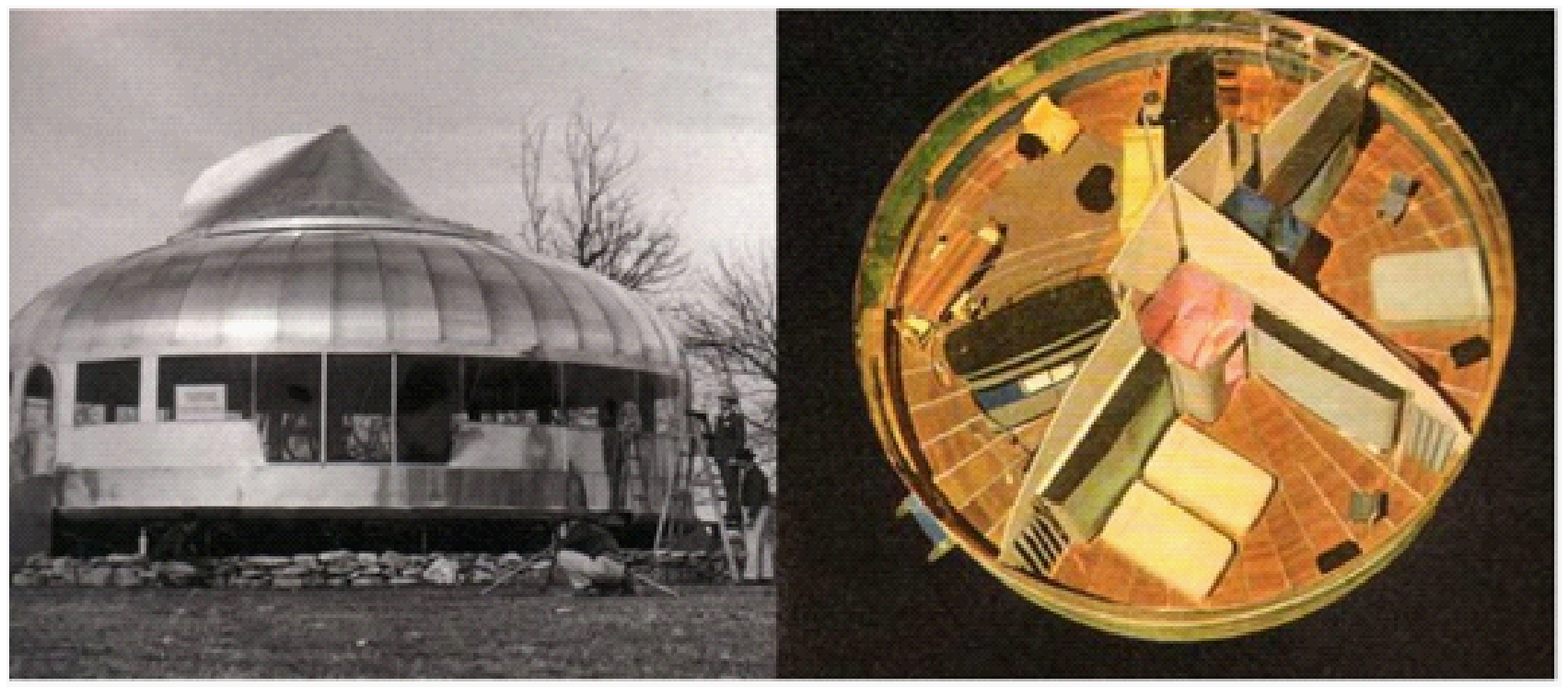

Figura 70: Desenho Dymaxion Wichita. (1946). Fonte: Disponível em: বhttp://www.epdlp.com/fotos/ buckminster2.jpg >Acesso em: 18 set 2010. 
O crítico Kenneth Frampton (1979), fala da Dymaxion como uma casa independente que significava, para Fuller, dinamismo e eficiência. Citava que Fuller não tinha preocupação com o contexto e a projetou para produção seriada. Fuller a definia como uma síntese entre o "arranha-céu americano e o pagode oriental" (FRAMPTON, 1997, p. 291), hexagonal, com plataformas ocas, suspensa e triangulada. Possuía um mastro central que agregava todos os serviços necessários

Observa-se que Fuller considerava vários aspectos tais como planta livre, estrutura autônoma, fechamento com uma membrana independente e, ainda atendia aos requisitos de utilização de alta tecnologia, baixo custo, customização das instalações, produção industrializada e podia ser produzida em um curto espaço de tempo.

Na geração de Kurokawa, em que os edifícios deveriam atender necessidades do momento, em uma sociedade em plena transformação, a menor durabilidade da casa de Fuller em relação às construções de concreto armado seria aspecto positivo para os arquitetos que estavam preocupados com os novos modos de vida.

Banham (1979) considera que a influência de Fuller, para Kurokawa, bem como para muitos arquitetos posteriores estava na utilização da tecnologia aplicada a materiais leves, elaborados em partes isoladas, na produção em série e na montagem no local de uso. Essa forma de fabricação, que não foi exclusiva de Fuller, foi uma das bases das intenções dos arquitetos modernos, mas Fuller conseguiu materializá-las de forma pioneira, se comparado aos arquitetos modernos (BANHAM, 1979).

Outra referência importante para os Metabolistas era a Casa do Futuro dos arquitetos Peter (1923 - 2003) e Alison Smithson (1928 - 1993). Era um modelo de habitar ideal, exibido na exposição "This is Tomorrow" na Whitechapel Art Gallery (Londres) em setembro e outubro de 1956. A casa tinha como pré-requisitos ser "popular, transitória, consumível, de baixo custo, produzido em massa, jovem, 
espirituosa, sexy, enigmática, fascinante, grande negócio"n2 (THIS IS A HOUSE?, 1956) , e o desafio era ser de plástico e conectada a controles de iluminação e televisão.

A "Casa Ideal" era localizada na cidade e tinha apenas uma cama para o casal. Alguns mobiliários podiam ser embutidos no chão quando não eram usados. O jardim fazia parte da casa, a casca era moldada em plástico e a cobertura de alumínio que refletia a luz solar. A pia para limpeza de louças era de fibra plástica reforçada e tinha um controle no piso, a banheira controlada termo-estaticamente e o chuveiro possuía secadores de ar nas laterais. Os aparelhos eletrônicos eram controlados manualmente. Um carrinho móvel possuía tudo que era necessário para servir um jantar. Os nichos de plástico serviam para armazenagem e os alimentos eram conservados com bombardeamento de raios gama e podiam ser estocados ao ar livre, e até mesmo os ovos ficavam em uma embalagem de plástico sem refrigeração. A casa possuía ar condicionado e sistema de aquecimento que irradiava do piso. Eles queriam provar que era muito mais fácil morar em uma casa do futuro (THIS IS A HOUSE?, 2006).

O casal Smithson fazia parte do Independent Group, que tinha o intuito de discutir a cultura contemporânea. Utilizavam revistas de ficção científica, filmes americanos e arquitetura moderna para trabalhar com a cultura visual. Fazia parte desse grupo: Lawrence Alloway $^{13}$ (1926-1990), Richard Hamilton ${ }^{14}$ (n.1922), Nigel Henderson ${ }^{15}$

12 Original em inglês: Popular, transient, expendable, low cost, mass produced, young, witty, sexy, gimmicky, glamorous, big business" in: Pearman, Hugh Meet the Smithsons: separating the hype from reality. Should Alison and Peter Smithson have stuck to talking?, Gabion, Retained writing on Architecture,

1998-2009. (THIS IS A HOUSE?, 1956)

13 Autor da introdução do catálogo da exposição "This is Tomorrow" com o título de "Design as a Human Activity", foi um crítico de arte, e tinha interesse na cultura de massa, design industrial, cibernfoitica e arte. Disponível em: <http://www.independentgroup.org.uk/contributors/>. Acesso em 21 set 2010.

14 Desenhista, trabalhou com microfotografias e Raio-X como base para suas expressão. Na exposição "This is Tomorrow" teve como tema os problemas de percepção. Disponível em: <http://www.independentgroup. org.uk/contributors/>. Acesso em 21 set 2010.

15 Fotógrafo de documentários e retratos, casou-se com Judith Stephen (antropóloga) que lhe mostrou o lado sociológico. Expôs colagens e objetos em "This is Tomorrow". Disponível em: <http://www. 

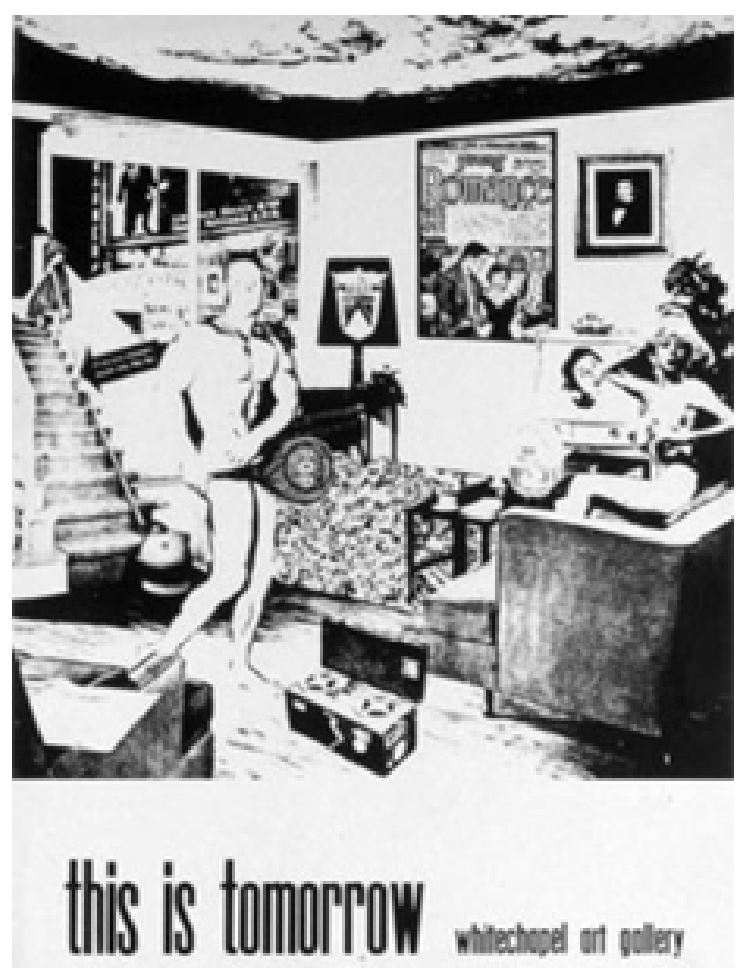

ong. 9- $\sec 9158$

Figura 71: Poster da exposição

This is Tomorrow. Fonte: (THIS IS A

HOUSE?, 2006) 


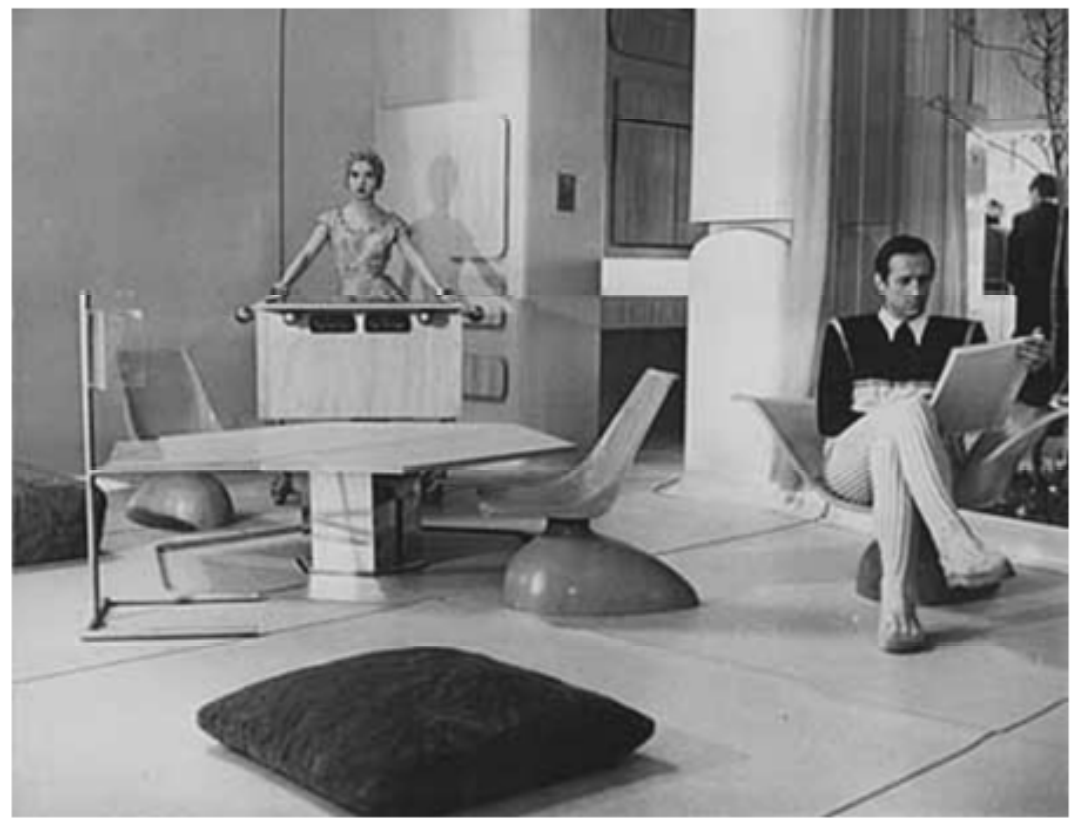

Figura 72: House of the Future, 1956. Fonte: (THIS IS A HOUSE? 2006) 
(1917-1985), J ohn MacHale ${ }^{16}$ (1922-1978), Eduardo Luigi Paolozzi ${ }^{17}$ (1924-2005), Alison \& Peter Smithson ${ }^{18}$ (1928-1993) (1923-2003).

No artigo “Mas hoje nós coletamos anúncios"19 publicado na revista Arkem 1957, os Smithsons fizeram uma crítica à sociedade de massa, explicitaram que a publicidade estava causando uma revolução na arte popular, social e política. Disseram que os produtos eram meros acessórios naturais de um modo de vida, pois os anúncios publicitários determinavam informações e padrões de comportamento.

No ramo da arquitetura, os Smithson consideravam que as indústrias de produção em massa deveriam reformular a cozinha, o banheiro, a despensa, e a garagem. Os produtos modulares pré-fabricados estavam dissociados do trabalho dos arquitetos e por esse motivo apresentavam uma qualidade inapropriada. Citaram como exemplo as gravuras japonesas nos anos 1920 e o ambiente de ornamentação (tokonoma) nos anos 1930 como exemplares de qualidade, diferente das influências das mídias na arte. Talvez seja por essa razão que o casal Smithson tenha proposto, uma casa com alta tecnologia que absorvia a cultura das mídias, mas que, no entanto, se apropriava da elaboração do projeto e que interferia intimamente na qualidade de vida das pessoas.

\section{A Casa do Futuro foi constantemente associada à Arte Pop pois, se por um lado}

\footnotetext{
independentgroup.org.uk/contributors/>. Acesso em 21 set 2010.

16 Conhecedor de tecnologia de ponta e da cultura popular, em 1954 exibiu uma colagem de transistor, que codificava o processo de comunicação. Autor de "The future of the future". Disponível em: <http://www. independentgroup.org.uk/contributors/>. Acesso em 21 set 2010.

17 Artista plástico, autor de Forms on a Bow (1949), Bunk (serigrafias-1972), morou dois anos em Paris, local que o influenciou definitivamente em suas obras. Disponível em: <http://www.independentgroup.org. uk/contributors/>. Acesso em 21 set 2010.

18 Um dos principais integrantes do grupo Team $\mathrm{X}$, Tinha como tema o design do efêmero, são autores do artigo "But today we collect ads", em que ele coloca a influência da cultura de massas nos modos de vida e na arquitetura (ARK novembro de 1957). Disponível em: <http://www.independentgroup.org.uk/ contributors/>. Acesso em 21 set 2010.
}

19 Original em inglês: But today we collect ads 
criticava a massificação dos produtos, por outro utilizava a produção para a democratização do objeto. As discussões críticas acerca da sociedade de massa ou cultura de massa envolveram duas correntes: a primeira conhecida como 'crítica', defendia que a cultura de massa não trazia em si o potencial de emancipação do indivíduo. E a corrente 'integradora', que via esse movimento com potencial democratizante, diminuindo as diferenças entre as classes sociais (BRETON \& PROULX, 2002, p. 134). Independente da postura escolhida em relação a estas duas vertentes, esse caminho que envolve as tecnologias de comunicação e informação, o consumo de massa e a disseminação das ideologias não teriam mais volta e modificaria definitivamente os modos de vida das gerações posteriores.

A influência dos Smithson, para Kurokawa, certamente tem relação com o pensamento conceitual que compartilhavam em relação à importância dada a história, cultura e valorização do homem e como os meios de comunicação influenciam os modos de vida da sociedade de massa. A vontade de explorar a tecnologia em seu ápice de forma a reverter os benefícios para os usuários na aplicação de um desenho de qualidade, vivido no cotidiano, também foi comum os Smithson, arquitetos que pensavam no design enquanto objeto e instrumento profissional. 


\subsection{Sobre a vida de Kisho Kurokawa}

A escolha da análise das cápsulas do arquiteto Kisho Kurokawa se deve ao nosso reconhecimento do mesmo como o principal representante dessa forma de habitação. Kisho Kurokawa ${ }^{20}$ (1934-2007) nasceu em Nagoya, província de Aichi - J apão, formou-se pela Universidade de Kyoto em 1957 e fez mestrado (1959) e doutorado (1964) na Universidade de Tokyo com o professor Kenzo Tange (19132005). Fazia parte do Tange Lab ${ }^{21}$ (1958-1964) junto com Sachio Otani ${ }^{22}$ (1926), Takashi Asada23 (1928-1987), Fumihiko Maki24 (n.1928), Arata Isozaki25 (n.1931) entre outros, o grupo que fazia parte do Tange Lab tinha como meta criar soluções para projetos de habitação devido ao crescente contingente populacional.

\section{Seguem algumas propostas de planejamento idealizadas pelos membros do grupo coordenado por Kenzo Tange na década de 1960.}

\footnotetext{
20 Imagem abaixo: Figura 76: Projeto Helix City (1961) - Kisho Kurokawa. As estruturas com formato espiral, para abrigar moradias lembram o DNA humano que foi responsável pela transmissão dos dados indispensáveis à vida. Fonte: Disponível em: 〈http://www.kisho.co.jp/ page.php/200>. Acesso em 18 set 2010 ..
}

21 Laboratório Tange - que reunia pesquisadores em torno das soluções para Tokyo - denominado de Tange Research Group

22 Arquiteto, graduado pela Universidade de Tokyo (1946), conhecido pelos seus projetos monumentais, com clareza nas estruturas e hierarquia nos espaços. Sua obra mais famosa foi o Kyoto International Conference Hall (1966). Disponível em <http://www.answers.com/topic/sachio-otani-3>. Acesso em: 16 set 2010.

23 Artista Plástico, nascido em Kyoto, formado pelo colfoigio Municipal de Arte de Kyoto em 1949, professor convidado na Universidade de Musashino. Disponível em: <http://www.kahitsukan.or.jp/asa_e.html>. Acesso em: 16 set 2010 .

24 Arquiteto formado pela Universidade de Tokyo, mestrado pela Academia de Arte de Cranbrook, mestrado de arquitetura pela Escola de Design da Universidade de Harvard, professor e pesquisador na Universidade de Tokyo, autor de Movement Systems in Cities (1965), Japanese Translation of Communitas (1965) entre outros, e autor dos projetos do novo projeto para World Trade Center 2012 e Notes on Collective Form (1994). Disponível em <http://www.maki-and-associates.co.jp/e/project/1.html>, acesso em: 16 set 2010. Imagem: Figura 77: Proposta para bairro de Shinjuko Tokyo (1964) - Fumihiko Maki, o arquiteto possui um trabalho sobre megaestruturas publicado em 1964. Fonte: Disponível em: ‘http://landarchy.org/ metabolists/images.html\#maki>. Acesso em: 18 set 2010.

25 Engenheiro graduado pela Universidade de Tokyo (1963), iniciou seu escritório em 1963. Autor dos projetos City in the Air, possui obras na China, Espanha, Italia, Polonia, Vietna. Disponível em: <http:// www. isozaki.co.jp/>. Acesso em: 16 set 2010. 
- Projeto para a Baía de Tókyo ${ }^{26}$ (1960) de Kenzo Tange (coordenador do grupo) e Tange Lab. A proposta utiliza a baía de Tokyo como espaço para implantar residências, serviços públicos, escolas, área comercial, estacionamentos e estação rodo-ferroviária. (fig.73)

- Projeto para a cidade helicoidap7(1961) - Kisho Kurokawa. As estruturas com formato espiral, para abrigar moradias lembram o DNA humano que foi responsável pela transmissão dos dados indispensáveis à vida. (fig.74)

- Proposta para bairro de Shinjuko Tokyo (1964) - Fumihiko Maki, o arquiteto possui um trabalho sobre megaestruturas publicado em 1964. (fig.75)

- Cidade sobre o $a r^{28}$ (1962) - Arata Isozaki. Tinha relação indireta com a cidade existente, uma cidade virtual, digitalizada, programada por computadores. As torres verticais eram conectadas entre si no espaço aéreo. (fig.76)

Os projetos tinham em comum a necessidade de criar espaços diversificados para a acomodação da população que se adensava na cidade de Tokyo. Para isso, utilizaram o espaço sobre o mar, ou o espaço aéreo em megaestruturas. Nos conceitos dessas edificações estavam embutidas as habitações em forma de cápsulas, a ocupação pressupunha ambientes de trabalho e os equipamentos urbanos, conforme já havia proposto Le Corbusier nas Unidades Habitacionais de Marseilles.

Kurokawa participou do último CIAM em 1956 e foi convidado para fazer parte do TEAM Xjunto com os Smithson no mesmo ano. No final da década de 1950, Kurokawa descreveu o grupo Team X como uma nova geração, "dos nascidos em 1930" (KUROKAWA, 1995 p.5), únicos capazes de sentir e resolver a situação daquele período; tendo, segundo ele, como elementos norteadores a mobilidade, o crescimento e a mudança.

26 Original em inglês: Tokyo Bay

27 Original em inglês: Helix City

28 Original em inglês: City in the Air 


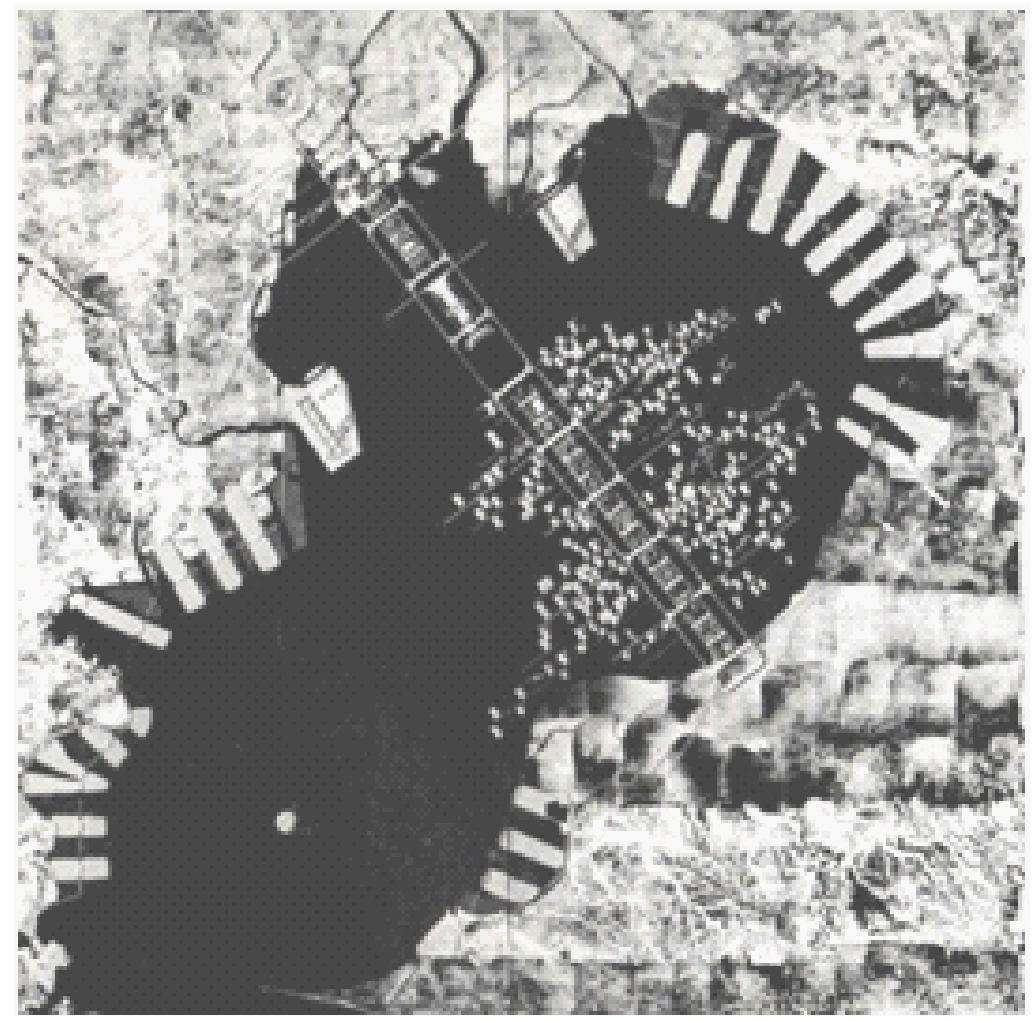

Figura 73: Projeto Tokyo Bay (1960)

- Kenzo Tange Fonte: (MÜHL, 1979. p. 26). 


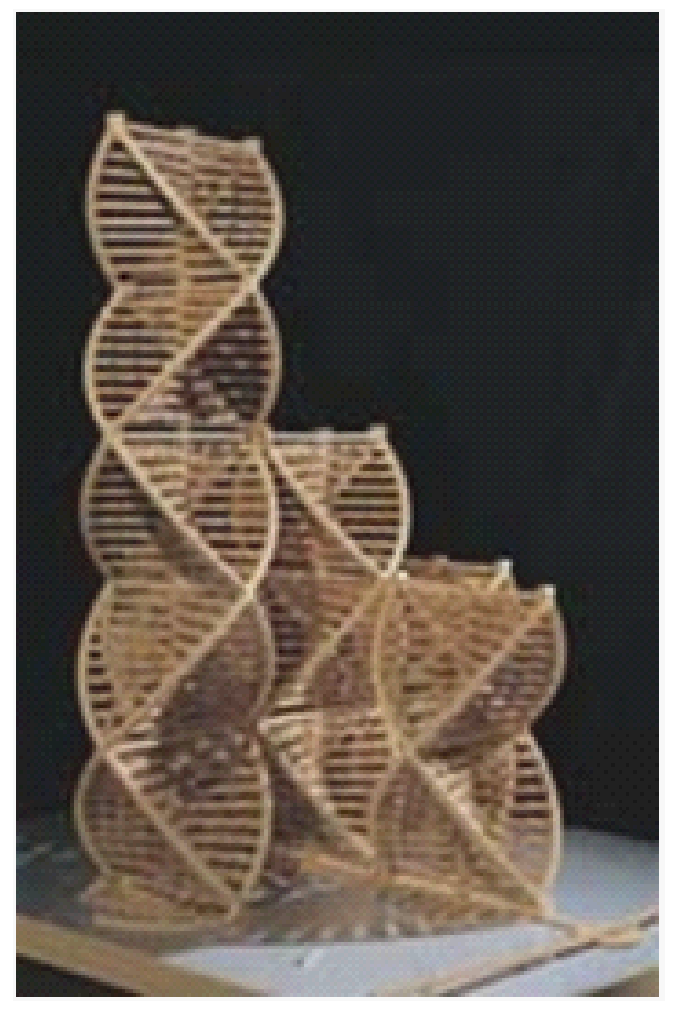

Figura 74: Projeto Helix City (1961) -Fonte: www. Kisho. co.jp. 


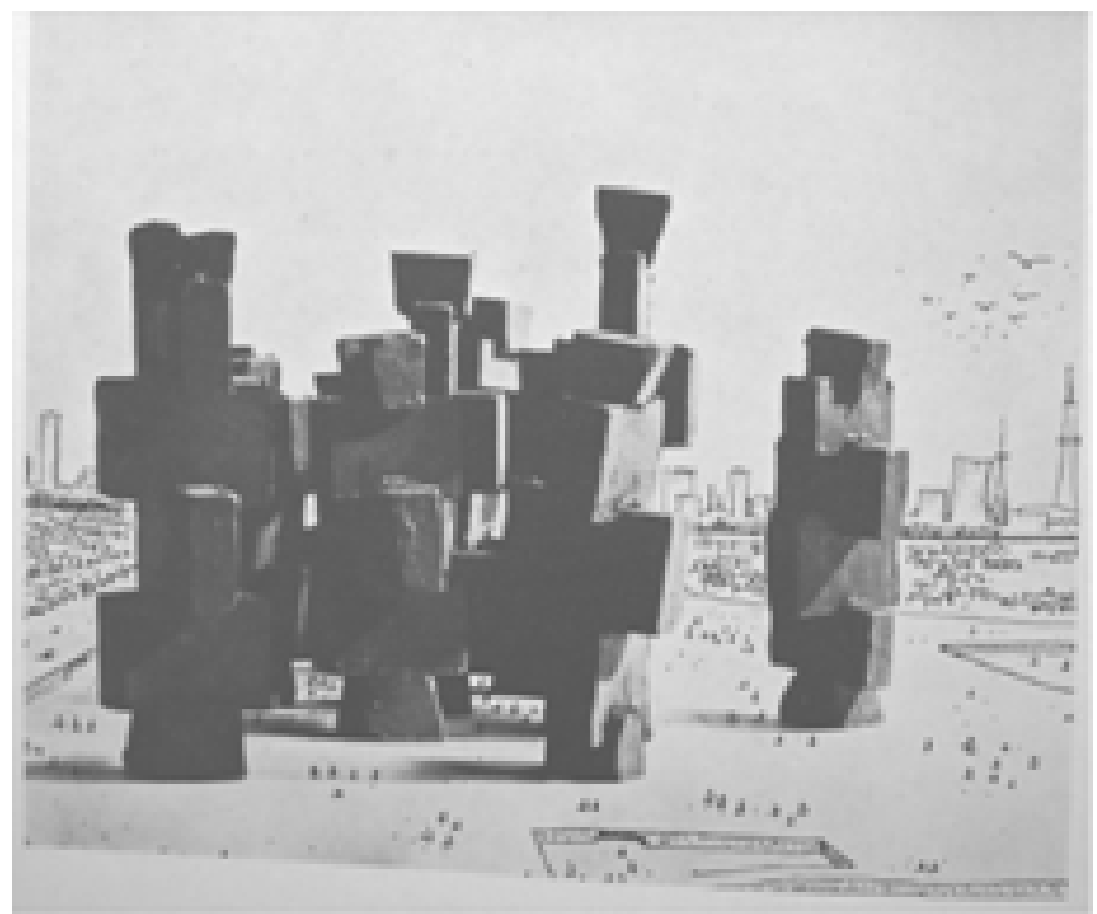

Figura 75: Proposta para bairro de Shinjuko Tokyo (1964) - Fumihiko Maki. 


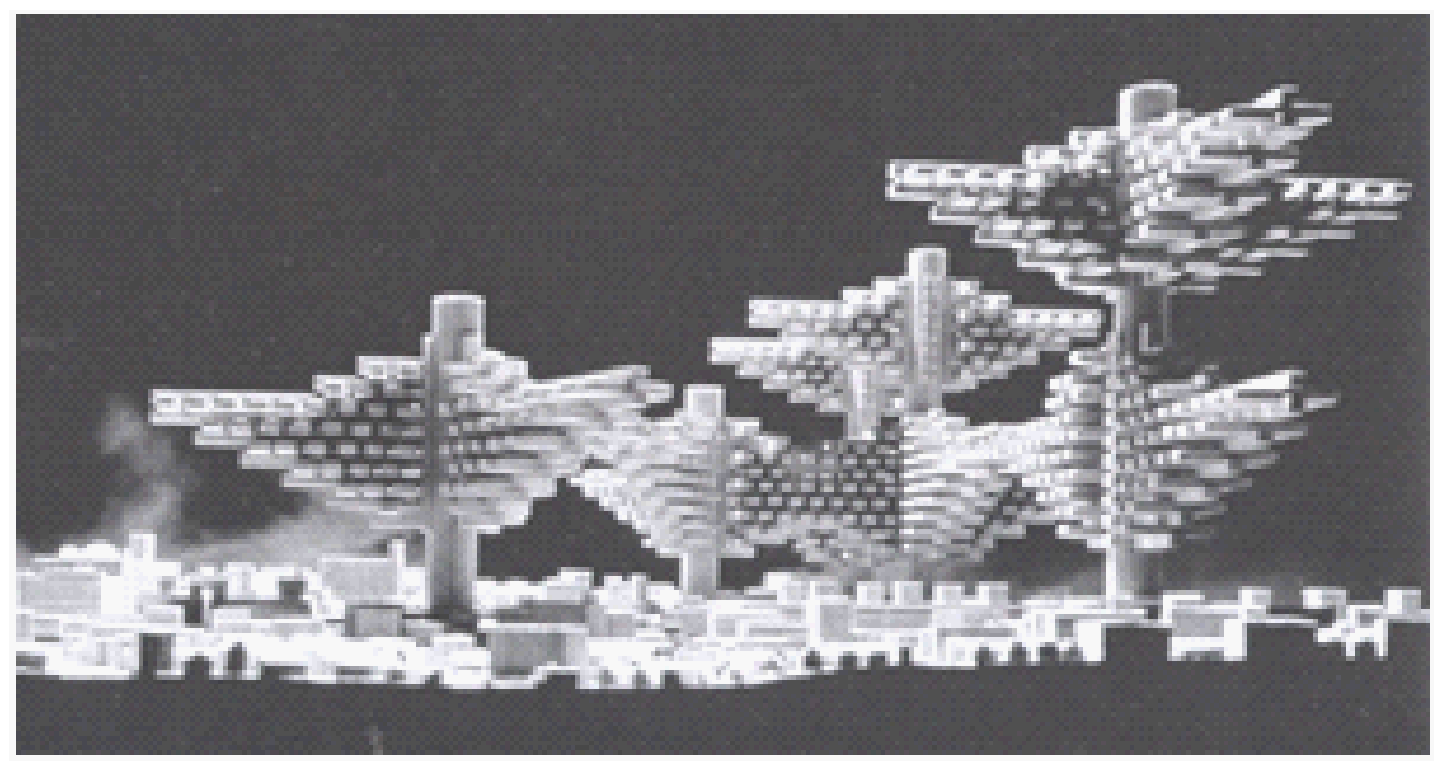

Figura 76: City in the Air (1962) - Arata Isozaki. Fonte: (ISOZAKI, 2004, p.144) 
A cisão com os paradigmas ideológicos anteriores ao Team $X$, fez com que Kurokawa se separasse do grupo de Tange e se reunisse ao Movimento Metabolista junto com Kiyonori Kikutake ${ }^{29}$ (n.1928), Fumihiko Maki (n.1929), Masato Otaka $^{30}$ (n.1923), Kiyoshi Awazu ${ }^{31}$ (n.1929), e Noboru Kawazoe ${ }^{32}$, como será visto a seguir.

O grupo Metabolista iniciou as reuniões para discutir sobre os paradigmas na arquitetura e no design dois anos antes da Conferência de Design Mundial do J apão ${ }^{33}$ que aconteceria em 1960. Nessa ocasião, o grupo publicou o documento “Metabolism 1960' que tinha como tema central 'Uma proposta para um novo Urbanismo ${ }^{34 "}$ ". Os integrantes do grupo pensavam na Arquitetura como uma expressão da vida, da sociedade e da cultura, que respondesse aos novos modos de vida e às novas demandas sociais (KUROKAWA, 1995 p.5).

Como Kurokawa afirmou:

'Nós consideramos a sociedade humana como um processo vital, um desenvolvimento contínuo de átomos na galáxia. A razão pela qual usamos a palavra metabolismo biológico foi porque acreditamos que o design e a tecnologia deveriam denotar vitalidade humana. Nós não acreditamos que metabolismo indique só aceitação de um processo natural, histórico, mas estamos tentando encorajar o desenvolvimento metabólico ativo de nossa sociedade com nossas propostas. 'Este

29 Arquiteto, planejador, participou ativamente do desenvolvimento do movimento metabolista, tendo criado a primeira casa metabolista do Japão (The Sky House- 1959).

30 Arquiteto, autor do projeto Bunka Kaikan em Chiba, Gumma Prefectural Museum of History, o Fukushima Prefectural Museum of Art. Disponível em: < http://www.kisho.co.jp/page.php/312>. Acesso em: 18 set 2010

31 Designer gráfico, diretor do Awazu Design Institute, consultor da exposição Tsukuba International Science Fair e produtor da Japan IBM Exibit. Autor de Dogu Ko (On Tools), Indasutoriaru Dezain (Industrial Design), Makunouch Bento no Bigakau (The Aesthetics of the Box Lunch).

32 Historiador e crítico, especialista em história da arquitetura. Escreveu artigos sobre o conceito metabolista.

33 Original em inglês: World Design Conference in Japan

34 A declaração tinha como propósito o planejamento das cidades e era intitulado "The Proposal for City Planning". (KUROKAWA, 2006, p. 3) 
foi um elemento importante em nossa declaração por duas razões. Primeiro, inclina nossos sentimentos de que a sociedade humana é composta por animais e plantas. Segundo expressa nossa convicção de que tecnologia é uma extensão da humanidade. Esta convicção contrasta com a crença ocidental de que modernização é uma repetição de um conflito entre tecnologia e humanidade ${ }^{35}$ (KUROKAWA, 1977, p. 26, tradução nossa).

Ao fazer essa declaração, Kurokawa considerava a arquitetura como um processo de design indissociável da tecnologia e ambos relacionados à necessidades humanas. Observa-se que ele indicava como aspectos importantes a cultura e a história. A valorização do aspecto natural ou ecossistema foi citado quando descrevia os animais e plantas como parte da sociedade. Todos esses pontos mencionados acima, segundo Kurokawa, foram determinantes para que o grupo Metabolista se tornasse independente do Tange $L a b$, cuja formação e ideologia se embasavam nas teorias de Le Corbusier. O conflito ideológico entre Kurokawa e Tange se estenderia por toda década de 1960, onde ambos defenderiam seus pontos de vista sobre o fazer arquitetura e urbanismo.

Segundo Montaner (1995), a formação do grupo Metabolista se deu por influência de Kenzo Tange, e a ideia básica era gerar propostas desde o desenho industrial até o urbanismo, sendo que os avanços tecnológicos e os sistemas de agregar cápsulas fossem básicos. Montaner defendeu que os Metabolistas imaginaram uma sociedade em contínuo desenvolvimento e mutação de um processo vital e tecnológico (MONTANER, 1995, p. 116).

\footnotetext{
35 Original em inglês: [...] 'We regard human society as a vital process, a continuous development from atom to nebula. The reason why we use the biological word metabolism is that we believe design and technology should denote human vitality. We do not believe that metabolism indicates only acceptance of a natural, historical process, but we are trying to encourage the active metabolic development of our society through our proposals.' This is an important element in our declaration for two reasons. First, it deflects our feelings that human society must be animals and plants. Secondly it express our belief that technology is an extension of humanity. This belief contrasts with the Western belief that modernization is a repetition of a conflict between technology and humanity. (KUROKAWA, 1977 p. 26)
} 


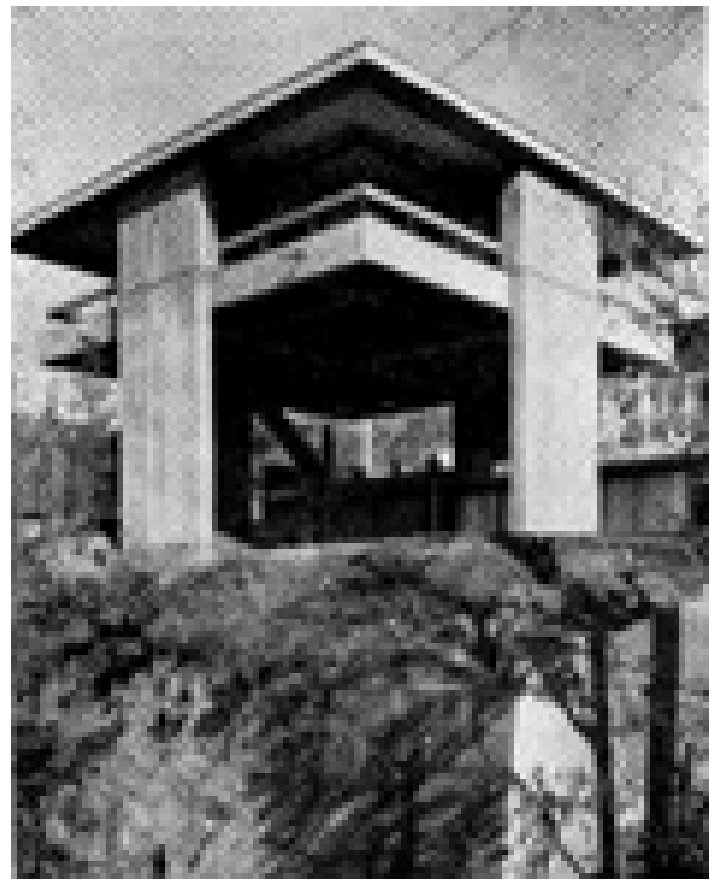

Figura 77: The Sky House (1959) Kiyonori Kikutake. Fonte: (KOJ IRO, 1958, p. 113-118) 


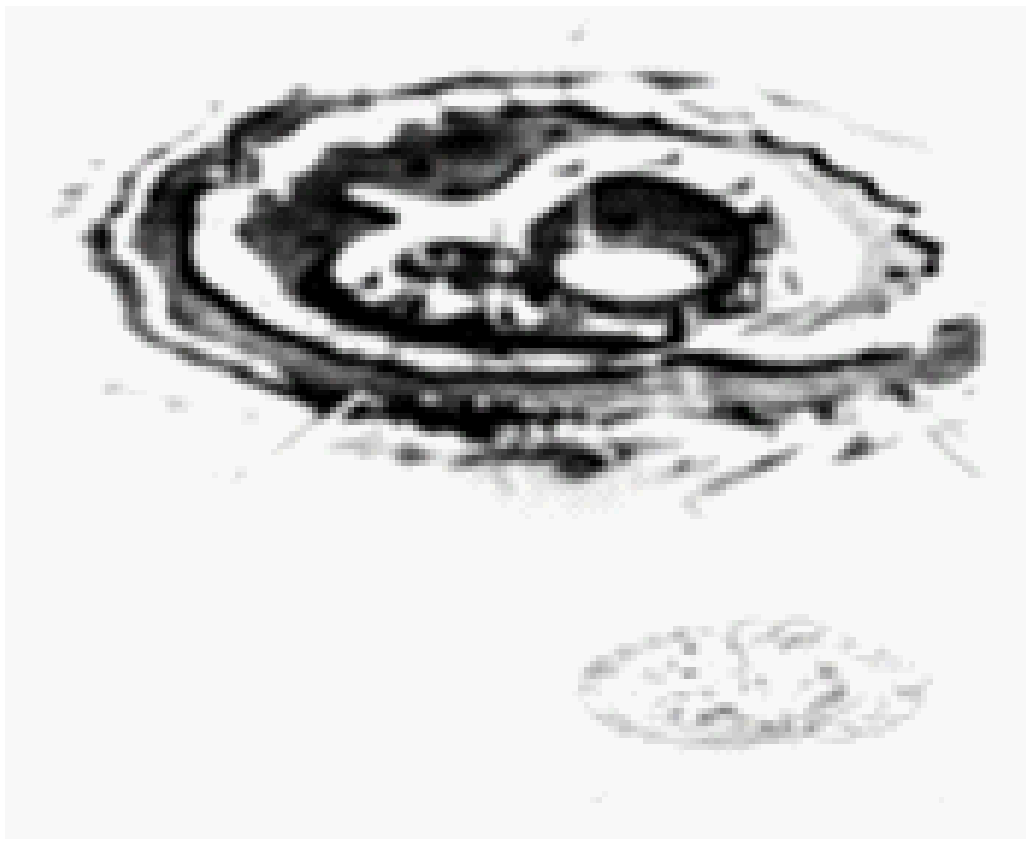

Figura 78: Marine City (1960) Kiyonori Kikutake. Fonte: Disponível em: 〈ttp://www.kikutake.co.jp/e/ top/top.html>. Acesso em: 16 set. 2010. 

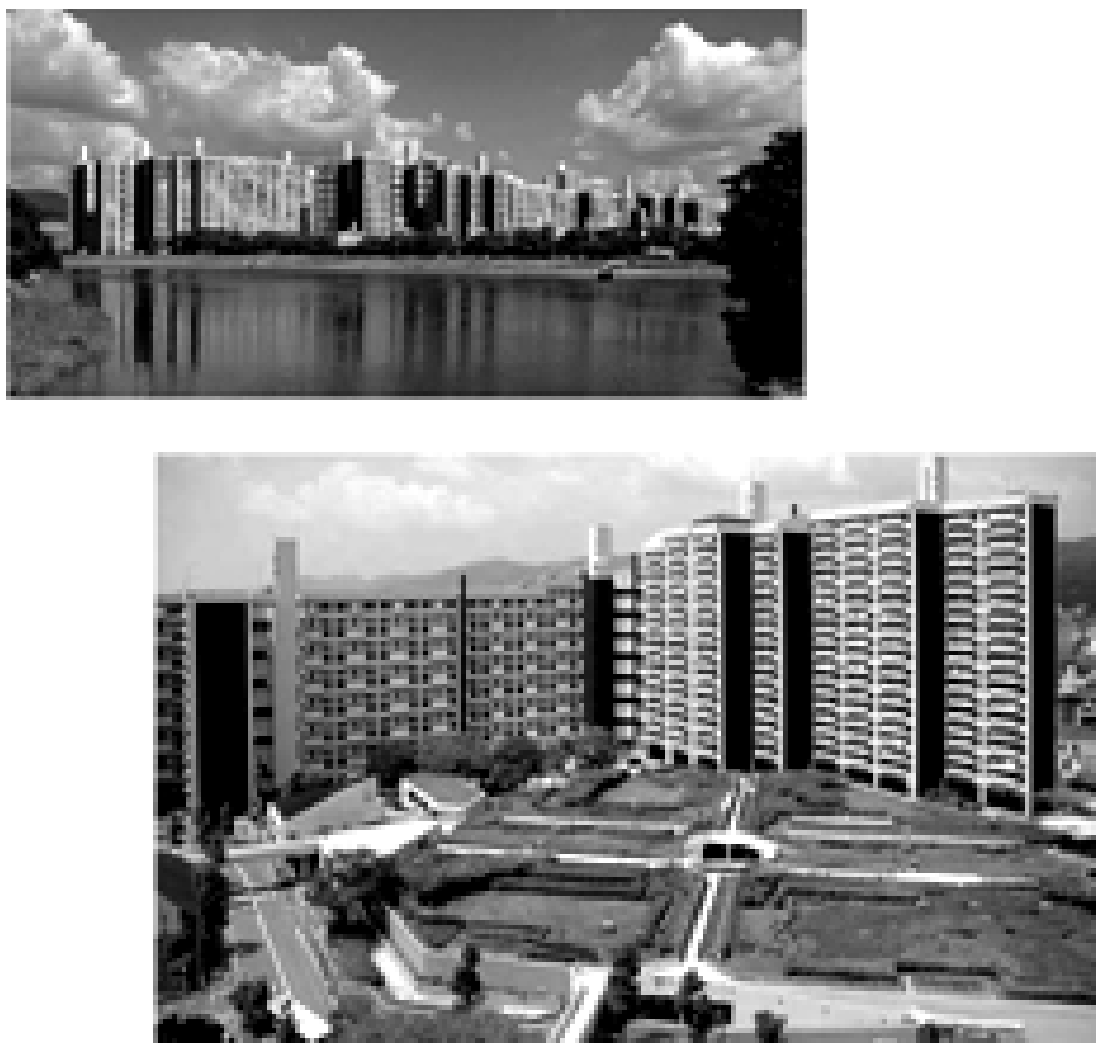

Figura 79: Matomatchi Apartments (1972), Masato Otaka. Fonte:

Disponível em: বhttp://landarchy. org/metabolists/images.

html\#maki>. Acesso em 18 set 2010. 


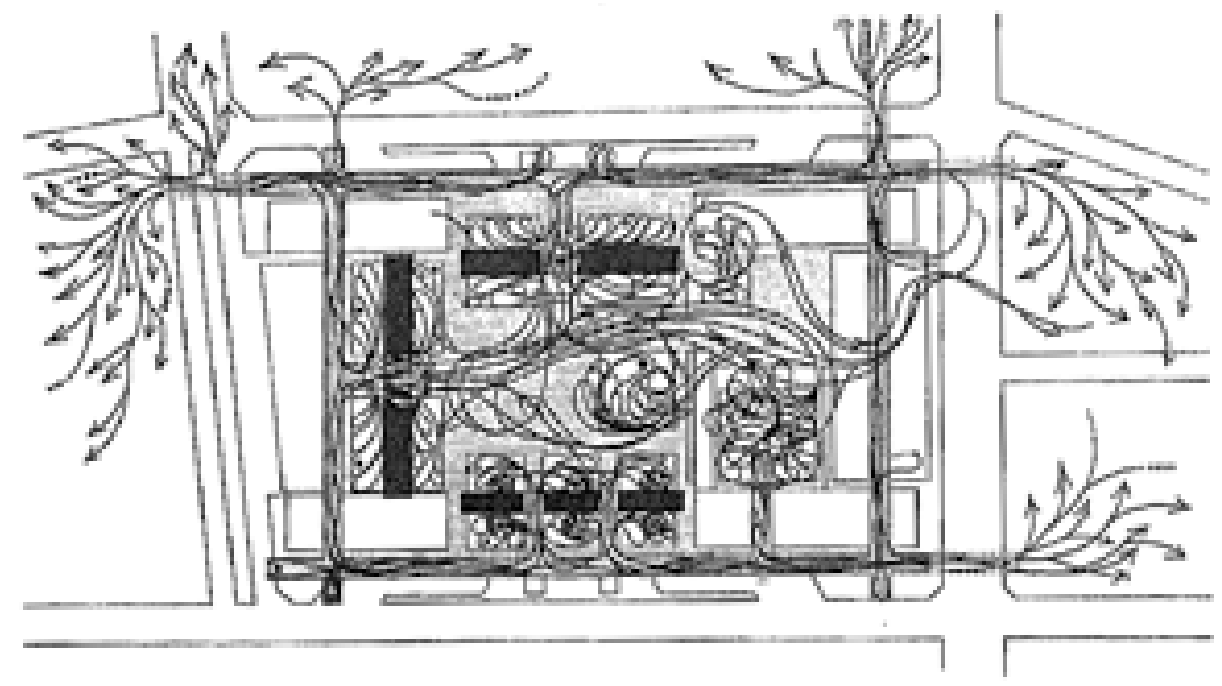

Figura 80: Movement Diagram - Kiyoshi Awazu. Fonte: MAKI, F. Investigation in Collective Form, A Special Publication, The School of Architecture, St. Louis: no. 2, 1964. 
No livro Después del movimiento moderno: Arquitectura de La segunda mitad De/ siglo XX de 1995, Montaner sugeriu que Tange fizesse parte do grupo dos Metabolistas, mas essa ideia não foi compartilhada pelos membros que faziam parte do grupo. Em uma entrevista realizada por Roger Connah ${ }^{36}$ a Fumihiko Maki, na revista The Japan Architect de 1987, Maki afirmava, em contraponto com Montaner, que o nome de Kenzo Tange não deveria ser associado ao movimento Metabolista, pois esse movimento foi fundado por uma nova geração de arquitetos japoneses em um momento particular de 1960 (MAKI, 1987, p. 68).

No artigo publicado na revista The Japan Architectsobre a teoria Metabolista em 1969, o crítico de arquitetura Noboru Kawazoe defendia que a arquitetura era parte de uma sociedade orgânica e descrevia o conceito da seguinte forma:

Vida é nada mais que um processo único no eterno fluxo do tempo. O sentido da integralidade do corpo biológico individual é o resultado da ação cíclica em cada um dos processos biológicos individuais. A coisa viva cria, tanto em seu próprio corpo como em seu ambiente, formas adequadas para as suas próprias atividades cíclicas ${ }^{37}$ (KAWAZOE, 1967, p. 77, tradução nossa).

Nesse artigo, Kawazoe (1967) mencionava que as discussões sobre o metabolismo tiveram início em conversas com Kiyonori Kikutake, Kisho Kurokawa e Noboru Kawazoe a respeito de projetos de "Cidades pelo mar e Cidades sobre o mar"38 antes mesmo que o grupo fosse formado. Kawazoe expunha que Kurokawa usava conceitos de entropia, unidade, probabilidade e multiplicidade no sistema de tráfego, Kurokawa utilizou fórmulas para o desenvolvimento do método. Kawazoe 36 Arquiteto, escritor e pesquisador inglês nascido em 1950, autor de vários livros, entre eles Writing Architecture - Fantomas, Fragments, Fictions an Archtectural J ourney through the Twentieth Century que ganhou o primeiro premio do International Book CICA. Disponível em: <http://www.museumstuff.com/ learn/topics/Roger Connah>. Acesso em: 18 out 2010.

37 Original em inglês: Life is but a single process in the eternal flow of time. The sense of completeness in the individual biological body is the result of the cyclic action in each of the individual biological process. The living thing creates, both in its own body and its environment, forms suitable to its own cyclic activities. [...] (KAWAZOE, 1967. p. 77)

38 Original em inglês: City by the sea and City over the Sea projects (KAWAZOE, 1967. p. 77). 
explicava que Kurokawa havia se baseado em um computador para elaborar os conceitos.

O princípio utilizado por Kurokawa como variável ou padrão para o sistema decimal do computador era de que no tráfego nunca havia mais de duas opções de caminho a seguir. Ele dividia os espaços como locais em espaços de fibras, com hierarquia determinada e espaços porosos, que eram áreas delimitadas por membranas e não tinham uma hierarquia bem definida (KAWAZOE, 1967). E descreveu:

O sistema decimal de Kurokawa não é um sistema de trânsito. É um sistema de padrão espacial comum topológico, dialogando entre as considerações do crescimento e dos espaços porosos. Possui espaços vizinhos que compartilham uma estrada e em contato um como outro não em pontos, mas em linhas. Ele exclui os espaços como a e b em $E$ e procura os espaços que se sobrepõem parcialmente como as da rua F. A arquitetura da rua de Kurokawa nasce da idéia de dois espaços em contato entre si por meio de linhas e não por meio de espaços ou pontos. Nesta base, ele desenvolveu a sua proposta brilhante Hishino em que as ruas tornam-se espaços comuns ${ }^{39}$ (KAWAZOE, 1967. p. 78, tradução nossa).

A área do projeto foi elaborada em três bairros com formas de loop (fig.81), sistema de tráfego de dígito binário, sistema de zonas de serviço lineares e sistema de rede linear de crescimento. A área central é nula e os serviços estão localizados nas periferias (KUROKAWA, 1977, p. 57).

39 Original em inglês: Kurokawa's decimal system is not a traffic system. It is a topological common spatial pattern system talking into consideration growth and porous spaces. It holds that neighboring spaces share $a$ road and contact one another not on points but on lines. He excludes spaces like $a$ and $b$ in $E$ and seeks spaces which partly overlap like hose in F. Kurokawa's street architecture is born of the idea that two spaces contact each other by means of lines not by means of spaces or points. On this basis he developed his brilliant Hishino proposal in which the streets become communal spaces. (KAWAZOE, 1967. p. 78) Imagem: Figura 83: Cidade Nova de Hishino (1966) - Localizada próxima a cidade de Nagoya, o projeto abriga 30.000 pessoas. Fonte: Disponível em : «ttp://www.kisho.co.jp/ page.php/194>. Acesso em 06 fev 2011. 


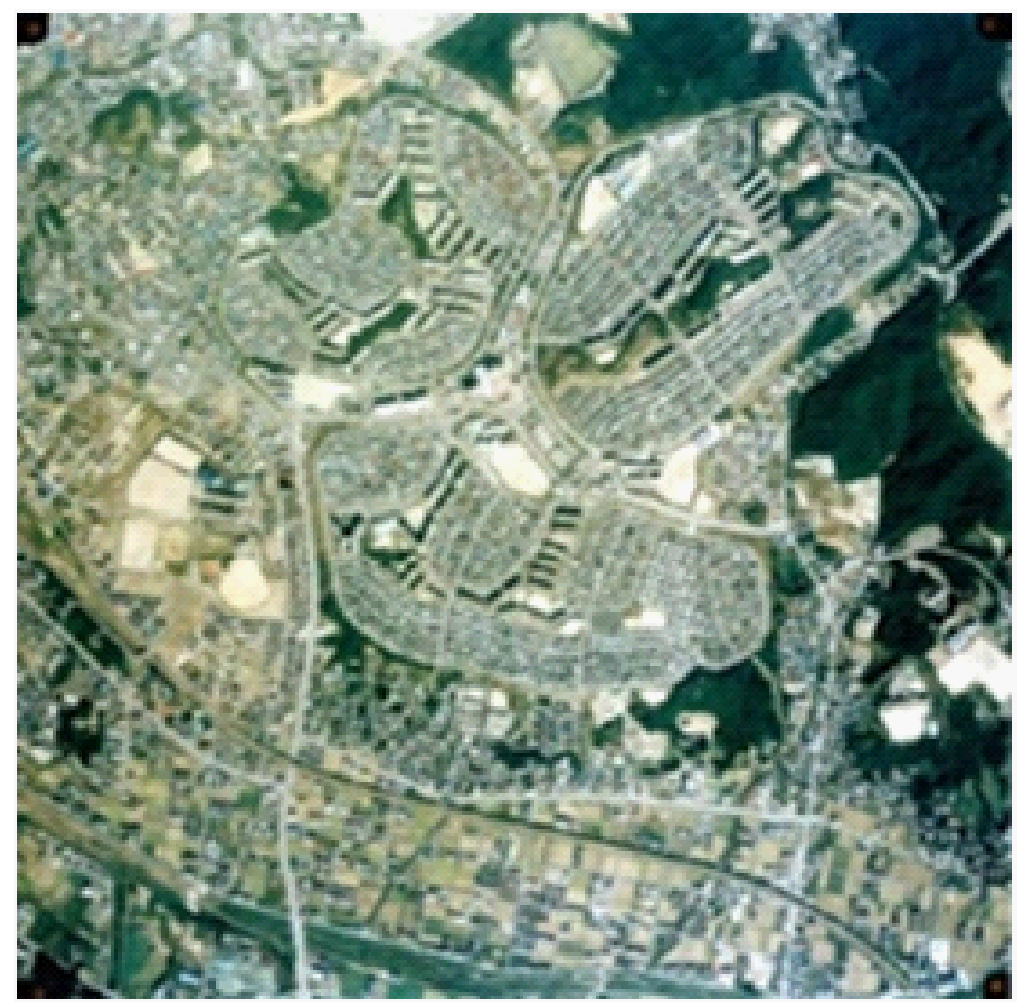

Figura 81: Cidade Nova de Hishino (1966) - Localizada próxima a cidade de Nagoya, o projeto abriga 30.000 pessoas. Fonte: Disponivel em $\varangle w w w$. kisho.co.jp.>: Acesso em 18 set 2010. 
No artigo Two systems of Metabolism, de 1967, Kurokawa fez a distinção entre "a era da máquina e a era da vida"40 (KUROKAWA, 1967). Considerava que a máquina de morar de Le Corbusier devia ser substituída pela era da vida e pela consciência individual. O paradigma da vida relacionava-se com a habilidade de crescer de forma autônoma através do esforço mútuo das funções.

Nesse mesmo artigo, o arquiteto introduziu um método que entendia a arquitetura e a cidade com padrões de informação para compor estruturas. Desse modo, analisava os movimentos, energia, comunicações, luz, som e ar; e estabelecia hierarquia entre eles (KUROKAWA, 1967). Estavam presentes na concepção, tecnologias como a automação, auxiliada pelo computador, com o intuito de analisar padrões de resposta de acordo com determinado estímulo.

Nessa mesma edição da The Japan Architect, o crítico Onobayashi descreveu que o grupo Metabolista entendia a sociedade com uma alta dinâmica e variada atividade, imersa em uma vasta rede de comunicações, com liberdade para escolher qualquer local de residência no globo, resultando em uma violenta mobilidade de pessoas, produção e consumo de massas (ONOBAYASHI, 1967. p. 79).

Esse era o contexto social do J apão naquele período, imerso na sociedade de massa, com uma alta necessidade de habitação social e com problemas resultantes das modificações dos modos de vida e da sociedade. Em constante modificação e, segundo as teorias Metabolistas, a arquitetura deveria dar conta de algo que cresceria, se expandiria, renovaria e desenvolveria (KUROKAWA, 2006, p. 6). Como dizia Kurokawa,

Eu ponderei a possibilidade de projetar cidades e da arquitetura dividida em grupos (célula) ou unidades de cápsula, a fim de se criar um sistema de arquitetura aberta no espaço e no tempo ${ }^{41}$

40 Original em inglês: From the Age of the Machine to the Age of Life (1958) (KUROKAWA, 2006). 41 Original em inglês: I pondered the possibility of designing cities and architecture broken down 
(KUROKAWA, 2006, p. 7).

Falando sobre rede de células, Kurokawa considerava uma unidade módulo, sendo a célula composta por outras subunidades modulares. As células vistas por Kurokawa eram associadas a um módulo, assim como o tatami era utilizado nas antigas casas tradicionais japonesas.

Para os japoneses que tradicionalmente tinham o hábito de utilizar os módulos de tatami, a maneira de pensar a cápsula não foi novidade, e foi facilmente assimilada. Como mensionou Higuchi (1961), as proporções e módulos de tatami foram baseados em princípios que envolviam duas dimensões planas produtos de relações numéricas.

O entendimento da cápsula como uma unidade modular foi fundamental para que Kurokawa elaborasse os conceitos sobre esse componente entendido como parte de uma estrutura e, que poderia se modificar de acordo com a necessidade do usuário no decorrer das modificações dos modos de vida. As cápsulas eram o próprio módulo, unidade celular ou unidade fundamental.

\subsection{Conceitos de habitat}

O conceito de habitat para alguns arquitetos envolvidos com as questões emergentes e que acompanhavam o grupo Metabolista, incluindo Kurokawa, referiam-se ao entendimento da cidade como um organismo. No final da década de 1950 e meados dos anos 1960, várias propostas de cidade foram discutidas no mundo e também no J apão.

A cidade passou a ser pensada em zoneamentos para cada atividade, e as várias funções se complementavam. A cidade era associada a um ambiente em constante crescimento e cenário onde os eventos aconteciam. Como comenta a entrevista de

into cluster (cell) or capsule units in order to create an architectural system that is open spatially and temporally. (KUROKAWA, 2006, p. 7) 
Tange e Isozaki nos anos 1959 e 1960:

[...] nesses anos, a urbanização tornou um ponto de grande urgência. Tivemos que abandonar a idéia de prédios urbanos individuais e pensar em termos de toda a cidade. O velho CIAM desmoronou-se, e do novo movimento foi a tentativa de iniciar, na verdade eu tinha a sua primeira conferência em Otterlo. Eu assisti à reunião e me lembro de ter a sensação de que os problemas que os japoneses estavam enfrentando eram comuns à maioria das nações do mundo ${ }^{42}$ (TANGE \& ISOZAKI, 1970. p. 23, tradução nossa).

Essa leitura sobre a cidade considerava o espaço urbano constituído de subsistemas e, quando a comunicação foi mencionada na entrevista, os arquitetos referiam-se às teorias de comunicação e informação, que estavam ligadas ao processamento e transmissão de dados e informações. Compreender o espaço como ambiente de comunicação e associadas a um significado implicava compreender que a arquitetura era capaz de transmitir uma mensagem e essa parecia ser a intenção desses profissionais. O conceito de habitat pode ser entendido no trabalho de Kurokawa, através da leitura do espaço da cidade e na aproximação da unidade que é a cápsula como serão abordados a seguir.

\subsubsection{A cidade por Kurokawa}

A cidade para Kurokawa era vista com os mesmos objetivos do grupo Metabolista, com o intuito de encontrar novas formas de acolher a população nas cidades. $O$ arquiteto Kurokawa desenhou vários croquis de cidades do futuro na década de 1960. O exemplo da Helix City, uma cidade espiral ${ }^{43}$ com estrutura cíclica, como

42 Original em inglês: [...] in those years, urbanization become a very pressing point. We had to abandon the idea of individual urban buildings and think terms of whole city itself. The old $\mathrm{ClAM}$ was crumbling, and the new movement was attempting to start; in fact I held its first conference in Otterlo. I attended the meeting and remember having the feeling that the problems we Japanese were facing were common to most of nations of the world. (TANGE \& ISOZAKI, 1970, p. 23)

43 Loop structure 
mostrado anteriormente, não possuía uma centralidade, e tinha um vazio em seu interior. Era uma mega-estrutura em dupla hélice com forma de DNA, tinha uma ordem própria que estruturava atividades e cuja conexão era o fluxo da informação. Como ele mesmo dizia:

[...] os aglomerados (células) são representativos disso, no lugar de uma estrutura administrativa e outros serviços no núcleo (centro da cidade), a porção periférica da membrana célular cresce como células (cachos), como unidades de serviço ou espaços de rua, formando uma rede ${ }^{44}$ (KUROKAWA, 2006, p. 6, tradução nossa).

O sistema de planejamento incluía o fluxo de informações, transportes, objetos, pessoas e energia. A cidade era composta por equipamentos que passariam informações. O uso do mecanismo chamado por Kurokawa de metabólico para pensar a cidade significava compreender a mesma como um organismo vivo que podia se modificar de acordo com as necessidades, inclusive ter capacidade de sofrer eventuais metamorfoses. Kurokawa justificava que, diante de uma situação inesperada, os organismos biológicos eram capazes de se autotransformarem para se adaptarem à nova situação (KUROKAWA, 1967, p. 81).

O conceito estava baseado em um sistema de rede, diferente daquelas estruturadas em forma de árvore ou piramidais ou mesmo aquelas com um eixo central, ou simétrico. A rede trazia a conotação de partes conectadas com o mesmo grau de importância, englobando a natureza em simbiose com a cidade. A arquitetura baseada no metabolismo consistia em reciclar os edifícios, as instalações e os espaços a cada vinte e cinco a sessenta anos (KUROKAWA, 1995).

Essa forma de entender a cidade foi materializada em um plano de desenvolvimento voltado para a sociedade da informação em 1970 pelo governo japonês. O objetivo desse plano era:

44 Original em inglês: [...] the cluster (cells) are representative of this. Instead of having administrative and other services in the core (city center), the cell membrane portion of the peripheral cell cluster grows in cell (cluster) units as service space and street space, forming a network. (KUROKAWA, 2006, p. 6) 
[...] a realização de uma "sociedade, que leve um estado geral de florescimento da criatividade intelectual humana, ao invés de um abundante consumo material (MASUDA, 1982, p. 13).

De acordo com Masuda, foram investidos sessenta e cinco bilhões de dólares de 1972 a 1985 em diversos ramos da automação e pesquisa. Nesse plano observouse uma fé exacerbada nos resultados, como se a informação possibilitasse que a sociedade pudesse atingir um estágio de maturidade e se tornasse autônoma. Como mostra abaixo:

A Sociedade da Informação não se orientará para o consumo material abundante, mas sim para a criatividade cognitiva individual.

Essa nova sociedade será alcançada sistemática e ordenadamente, sem traumas. Nela, a privacidade se tornará desnecessária.

Será conseguida a democracia participativa, na qual, com todas as informações disponíveis, respeitado o ponto de vista individual, todos participarão nas tomadas de decisão. As soluções serão buscadas através da persuasão e do acordo, dividindo igualmente benefícios e sacrifícios, de modo que, decidida a solução, e todos os cidadãos cooperem na sua aplicação (MASUDA, 1982. p. 13).

Os anos 1960 marcaram o salto do país na era tecnológica, o J apão estava entre os primeiros nas transmissões de imagens via satélite a outros continentes. Os trens Shinkansen atingiam $200 \mathrm{~km} / \mathrm{h}$, nas rotas de Tokyo a Osaka. Os aparelhos transistorizados de rádio e televisão substituíam os aparelhos de válvula (SAKURAl, 2007. p. 209). O desenvolvimento, como seria esperado, se deu no aspecto tecnológico, mas não foi correspondido na autonomia dos indivíduos que tinham a oferta das informações como pressupunha o plano.

Seguindo essa tendência na revista The Japan Architect de novembro e dezembro de 1987, havia um artigo sobre a proposta de Kisho Kurokawa para a baía de Tokyo. Kurokawa defendia a cidade planejada, para o ano 2025, que removia as funções da capital para a baía e se estendia por um raio de $500 \mathrm{~km}$ nas cidades de Nagoya, 
Osaka e Kyoto. Para isso havia a necessidade de duas tecnologias básicas: a primeira, que ele chamava de Linear Motor Car, um meio de transporte que corria a uma velocidade de $500 \mathrm{~km} / \mathrm{h}$ e a segunda, um sistema de fibra ótica que facilitaria a comunicação entre as funções descentralizadas da capital pelo Metropolitan Corridor (KUROKAWA, 1987. p.49).

O Metropolitan Corridor seria formado por um complexo político, econômico e de atividades culturais. A centralidade estaria dissolvida em um núcleo linear com vários pontos. $O$ arquipélago japonês seria considerado uma série de círculos concêntricos agrupados em forma de nós, como mostram as figuras a seguir.

Esse sistema de planejamento poderia ser comparado ao Potteries Thinkbelt do arquiteto inglês Cedric Price ${ }^{45}$ (1934-2003), que propôs um cinturão de equipamentos de ensino e cultura, ao longo de um vale, publicado pela primeira vez na revista Architectural Designem 1966. Era um projeto de revitalização de uma área industrial em Staffordshire - Inglaterra. A descentralização dos equipamentos estava organizada de acordo com uma antiga linha férrea em área industrial, e deveria promover a integração de ensino e pesquisa. A práxis integrada à ciência pura e à aplicada, entre a indústria e a academia. As unidades de ensino, laboratório e moradias estavam dispersos nos pontos do meio de transporte (PRICE, 1966, p.484).

A semelhança entre os projetos estava na organização sistêmica das atividades, no controle através de máquinas de informação e na utilização dos meios de comunicação. Segundo o cibernetista Gordon Pask (1969), essa forma de pensar arquitetura estava intimamente relacionada à cibernética, pois as cidades crescem e evoluem. Portanto, os projetos arquitetônicos necessitavam de regras para o seu desenvolvimento saudável. Ele ainda escreveu:

45 Foi um arquiteto preocupado em nas modificações sociais, trabalhou com a preocupação de promover o desenvolvimento intelectual e social. Dois de seus projetos são considerados ícones: Fun Palace e Poteries Thinkbelt. 
Em outras palavras, um arquiteto responsável deve estar ciente das propriedades evolutivas; ele não pode meramente ficar parado e observar a evolução como algo que acontece em suas estruturas. [...] é uma versão cuidadosamente especializada de como se manifesta no trabalho dos japoneses ${ }^{46}$ (PASK, 1969, p.478, tradução nossa).

Cedric Price utilizava o meio de transporte físico como elemento de acesso ao conhecimento. A comunicação era considerada instrumento fundamental para o processo de aprendizado, traduzida por Kurokawa para a tecnologia de transporte. Embora não tenhamos encontrado indícios de que Kurokawa tenha estudado a cibernética, vários de seus projetos e discursos lembram e se apropriam de termos dessa teoria.

46 Original em inglês: a responsible architect must be concerned with evolutionary properties; he cannot merely stand back and observe evolution as something that happens to his structures [...] is a carefully specialized version of $c$ as manifest in the work of the Japanese (PASK, 1969, p. 478). 


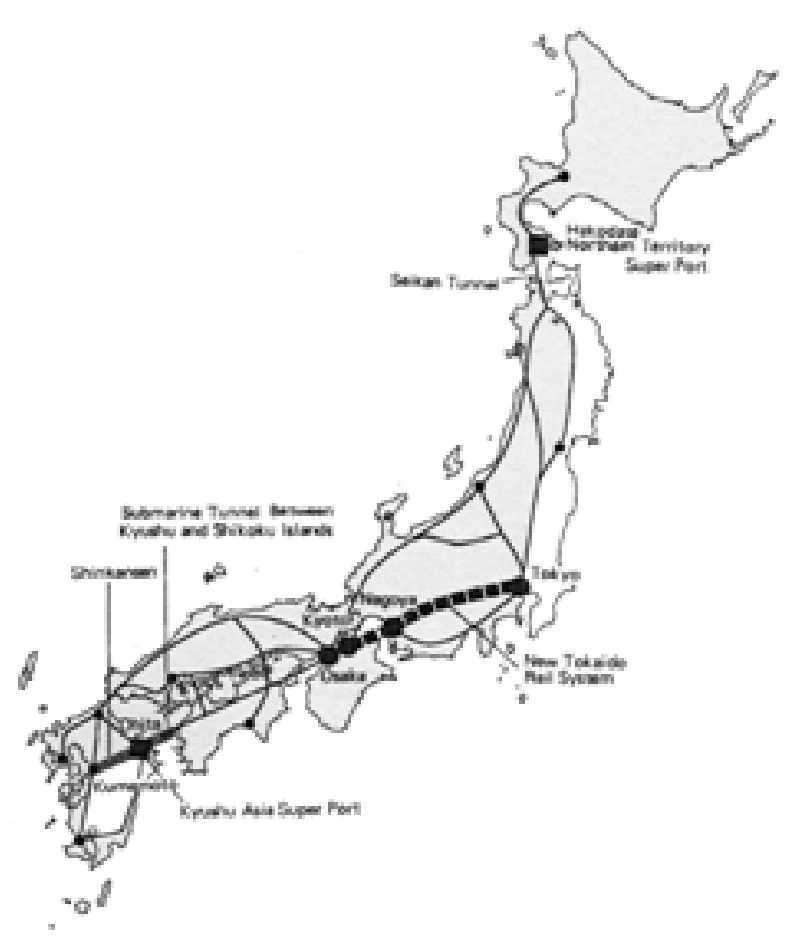

Figura 82: New Tokaido Rail
System - projeto de tráfego para
o plano de Kurokawa, fonte:
(KUROKAWA,

166 


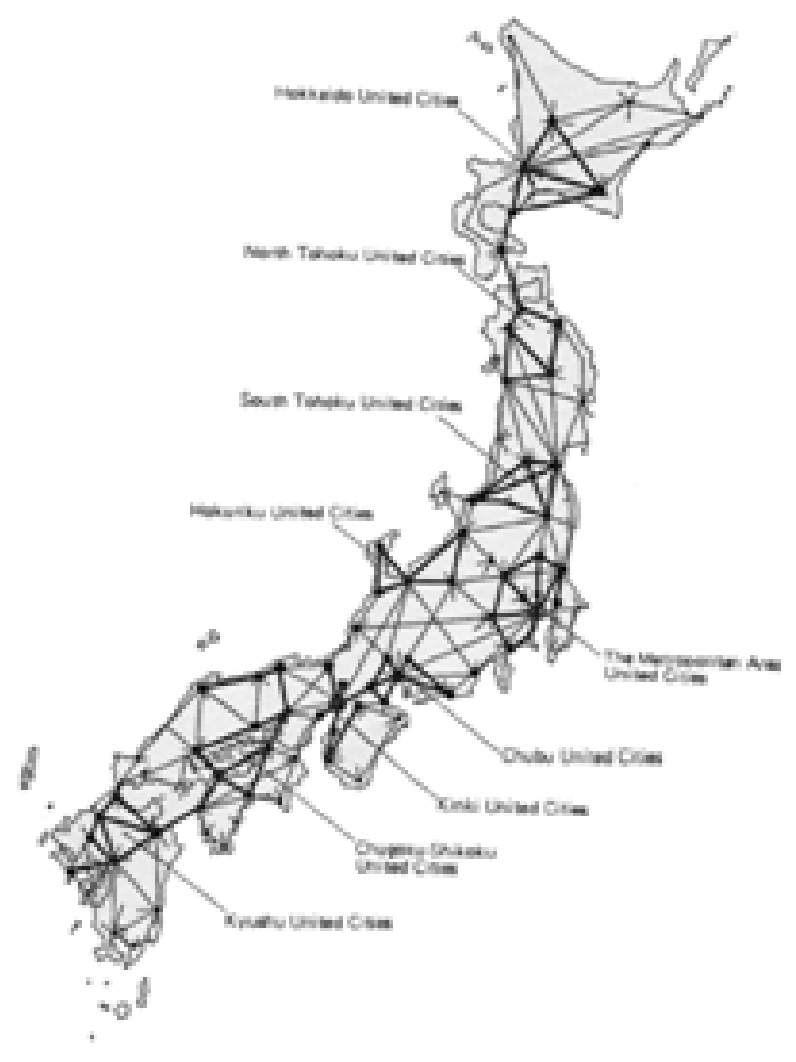

Figura 83: Rede Metropolitana do J apão, com investimento prioritário nas principais cidades de todo território japonês. Fonte: (KUROKAWA, 1967, p. 54). 


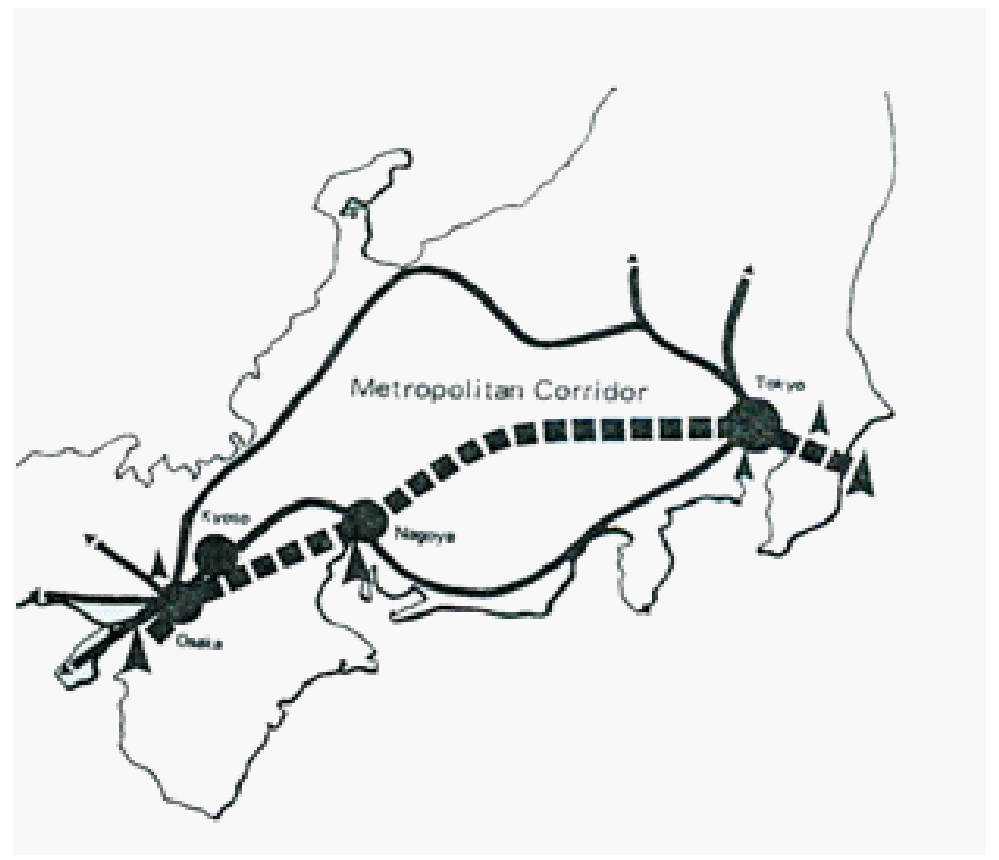

Figura 84: Rede de capitais formada em três pontos, Kyoto (palácio real e capital cultural), Nogoya e Osaka (ministérios) Fonte: (KUROKAWA, 1967, p. 55). 


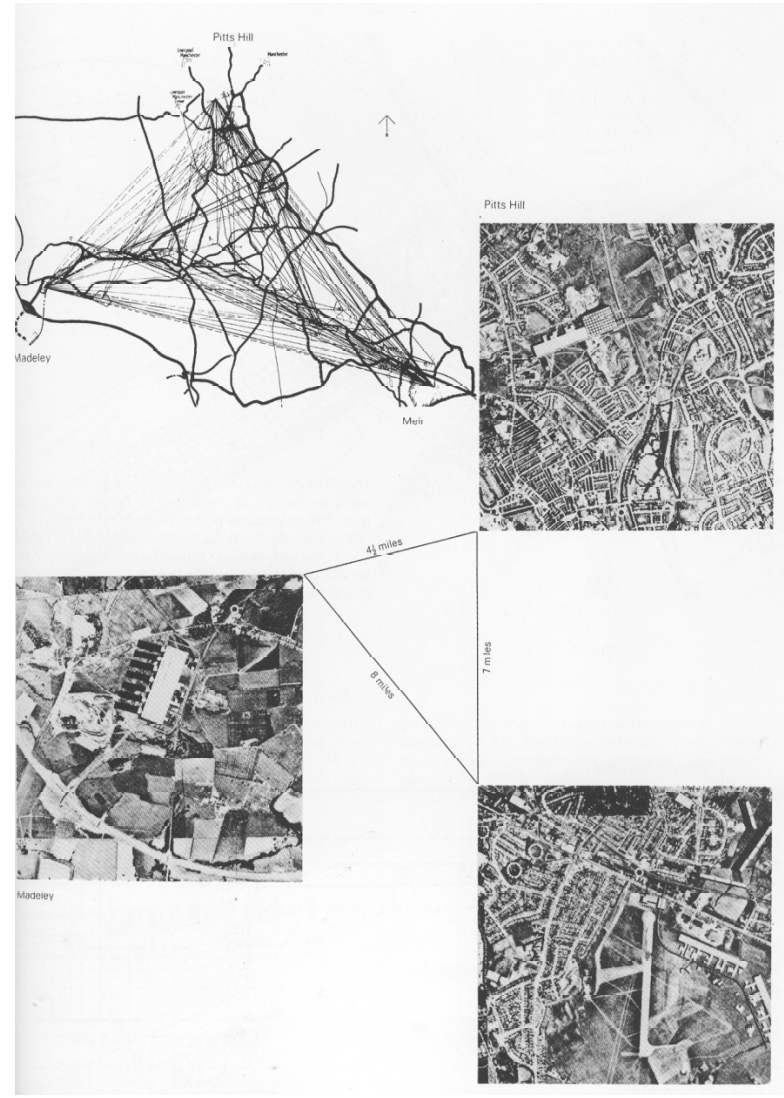

Figura 85: North Staffordshire -área do Potteries Thinkbelt. Fonte: (PRICE, 1966, p. 484). 


\subsubsection{Os princípios das cápsulas, segundo Kurokawa}

Outro ponto essencial para entender o conceito de habitat é lançar um olhar para os princípios das cápsulas. De acordo com Kurokawa (1977), o estudo das cápsulas foi iniciado em $1959{ }^{47}$ como "unidades espaciais" ou "células". Kurokawa pretendia estabelecer uma nova ordem na arquitetura, através de unidades para indivíduos. Essa teoria relacionava-se com,

[...] à busca de uma nova imagem do homem e de uma nova comunidade em meio ao fluxo da sociedade contemporânea $[\ldots]^{48}$ (KUROKAWA, 1977, p. 75, tradução nossa).

A Declaração das Cápsulas era descrita em oito pontos:

1. A cápsula era uma arquitetura ciborgue;

2. A cápsula era uma habitação para o Homo Movens,

3. A cápsula sugeria uma sociedade diversificada;

4. A cápsula era para um novo sistema familiar centrado nos indivíduos;

5. A cápsula satisfazia as necessidades espirituais;

6. A cápsula era para uma sociedade tectrônica (technological + eletronic);

7. A cápsula era produzida em massa para as necessidades individuais;

8. A cápsula era produzida sob a lógica da não uniformidade e pensamento não sistemático;

A primeira declaração dizia que a cápsula era uma arquitetura ciborgue. Segundo a declaração, homem, máquina e espaço formavam um novo corpo. A cápsula propiciava um meio peculiar, criando um equilíbrio em que o controle

47 O artigo que trata sobre a Declaração das Cápsulas foi publicado inicialmente em 1969 na revista Space Design.

48 Original em inglês: [...] the quest for a new image of man and a new community amdst the flux of contemporary society $[\ldots]$ 
e manutenção da máquina realizada pelo homem eram codependentes. Esse dispositivo era como um equipamento que desempenhava funções além das capacidades humanas nos quais sem eles não seria possível sobreviver. Era um sistema desenvolvido para estar em simbiose entre homem e máquina (KUROKAWA, 1977, p. 75).

O invólucro formado pela cápsula ou máquina em união com o homem propiciaria um meio em equilíbrio nunca pensado anteriormente, um ambiente protegido e favorável à vida humana. $O$ termo máquina se referia a um equipamento construído, capaz de suprir as necessidades de sobrevivência, tais quais as cápsulas submarinas ou espaciais. O desenvolvimento da tecnologia nas diversas áreas da ciência foi decisivo para a elaboração dessas unidades.

A segunda declaração falava que a cápsula era uma habitação para o Homo Movens. A cápsula, segundo Kurokawa, era a representante concreta da arquitetura móvel, para o homem móvel. A mobilidade se tornou um padrão de vida devido às longas distâncias percorridas entre o local de moradia e trabalho e, as possibilidades de viagens de avião em tempo mínimo. Essa era a condição do homem dinâmico da cidade. Além disso a cápsula podia ser vista como uma forma expandida da casa, como uma segunda casa em locais diferentes. As cápsulas podiam ser fixas ou móveis (KUROKAWA, 1977, p. 77).

Essa declaração era similar àquela de Yona Friedman descrita no capítulo um. Friedman assim como Kurokawa trabalharam com o conceito de mobilidade do homem, como um ser dinâmico e com vontades próprias. Ambos sugeriam a utilização de conceitos de J ohan Huizinga autor de Homo Ludens, que desenvolveu a teoria dos jogos. Kurokawa defendia a ideia de que as cápsulas representavam uma emancipação do homem em relação aos edifícios e era um exemplo de arquitetura móvel.

$\mathrm{Na}$ terceira e quarta declarações, a cápsula sugeria uma sociedade diversificada, 


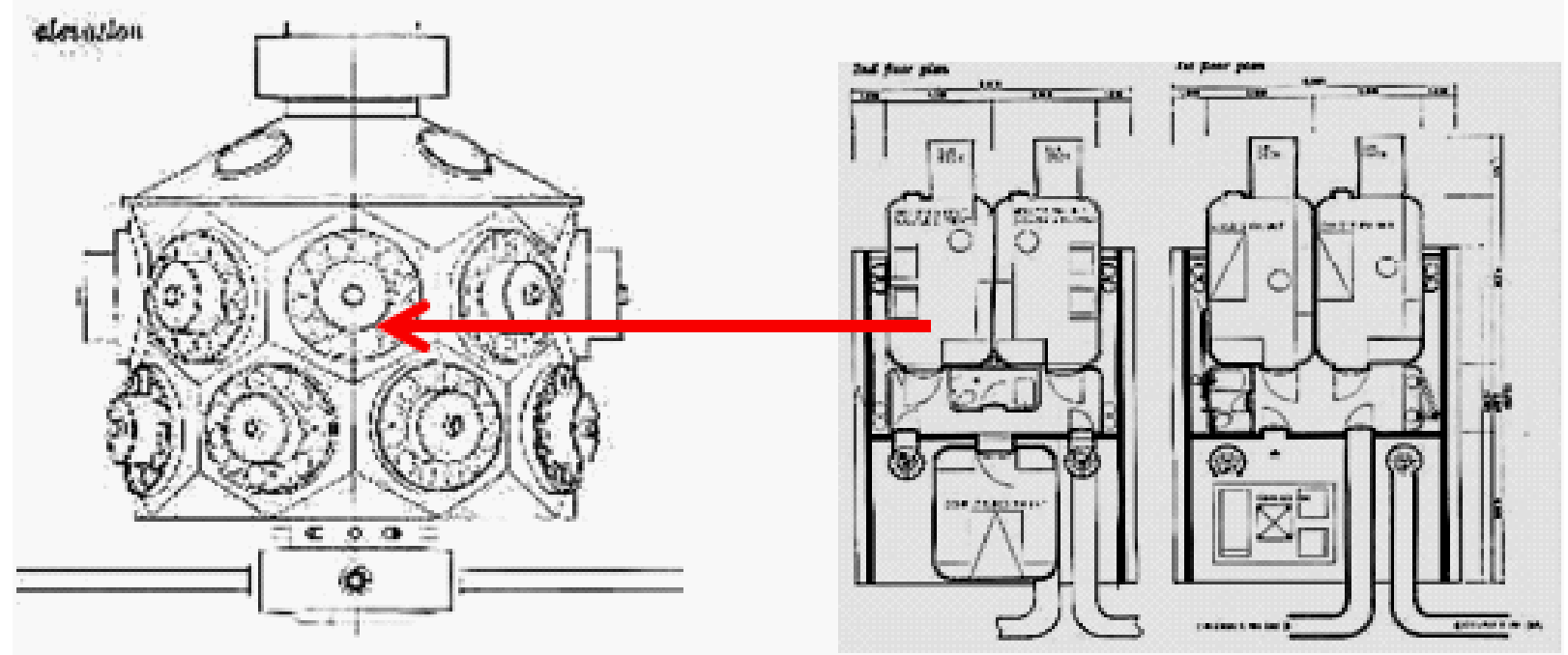

Figura 86: Tetsuya Akiyama, Iwao Kawakami, Norio Sato and Yuji Shiraishi. Menção Honrosa no concurso Residential Design Competition de 1966. Fonte: The Japan Architectno. 126 de 1966, p. 44-45. 
Para Kurokawa, os membros da sociedade eram altamente individualizados e envolvidos com seus objetivos. A ordem social se manteria se cada um buscasse sua felicidade e se a liberdade e uma gama de opções fossem possíveis para os indivíduos..

De acordo com Sakurai (2007), após a Segunda Guerra Mundial, a família patriarcal e que tinha responsabilidade pelos avós foi desvalorizada e era considerada um impedimento ao desenvolvimento da liberdade individual. De acordo com a autora, o lar tradicional '[...] foi abolido e deu lugar à total igualdade de todos os membros da família [...] (Sakurai , 2007, p. 310). Essas modificações reforçavam a postura de Kurokawa em diminuir o habitat para o indivíduo e incentivar a adoção dos valores ocidentais, como é comentado no decorrer deste capítulo.

A cápsula foi planejada para um novo sistema familiar centrado nos indivíduos. As casas baseadas em casais, pais e filhos seriam expressas em múltiplos espaços individuais. O espaço seria o mínimo necessário para um indivíduo, as casas do futuro seriam um agregado de espaços para indivíduos (KUROKAWA, 1977 p. 80).

Em decorrência dessa visão individualizadora de Kurokawa e de vários arquitetos desse período, praticamente todos os concursos da década de 1960, registrados na revista The Japan Architect, traziam soluções semelhantes para as habitações, como o exemplo anterior, a quantidade de cápsulas dependia do agrupamento familiar e se encaixavam nas naves da estrutura maior.

Na quinta declaração, referia que a cápsula satisfazia as necessidades espirituais; a junção das cápsulas em um espaço comum conformaria um espaço social, uma comunidade autosuficiente, onde o cotidiano seria realizado dentro de um círculo fechado, transcendendo o cotidiano. A noção de domicílio se tornaria cada vez mais abstrata com a crescente mobilidade. $O$ homem necessitaria de locais de acolhimento, conforto e refúgio espiritual (KUROKAWA, 1977, p. 81). 
Ainda de acordo com Kisho Kurokawa, a mobilidade seria possível quando associada a um refúgio espiritual, local em que os indivíduos se sentissem acolhidos.

De acordo com Kurokawa,

A cápsula é definida como um espaço que garante a completa privacidade para o indivíduo. Assegura a independência física e espiritual individual ${ }^{49}$ (KUROKAWA, 1977, p. 82, tradução nossa).

A declaração número seis, descrevia a cápsula para uma sociedade tectrônica. (technological + eletronic). Significava que a cápsula era regulada por um mecanismo de feedback, com informação orientada, de forma a rejeitar informações indesejáveis, e realimentado de informações desejáveis. Kurokawa considerava que a cápsula era um espaço apropriado para essa regulação, garantindo assim a subjetividade e independência dos usuários. Colocava ainda que existiam dois estágios para a sociedade tectrônica; o primeiro em que o usuário pagava pela informação e o segundo em que a informação seria do tipo criativa, em que o usuário realimentaria o sistema de informações (KUROKAWA, 1977, p. 82).

Observa-se que Kurokawa falava de um sistema de comunicação que se retroalimentava e retornava aos usuários na forma de informação criativa. Nesse ponto parecia que ele estava predizendo um sistema como da internet. É certo que nesse período de 1960 a 1990 as tecnologias de informação e comunicação estavam em desenvolvimento acelerado. A Arpanet ${ }^{50}$ foi o embrião da internete data de 1968, apesar do uso ser restrito, a possibilidade já existia no inconsciente coletivo.

Na sétima declaração, descrevia que a cápsula era produzida em massa

49 Original em inglês: The capsule is defined as a space which guarantees complete privacy for the individual. It assures the physical and spiritual independence of the individual. (KUROKAWA, 1977, p. 82) 50 Advanced Research Projects Agency, ARPA (1962), consistia em uma rede de computadores conectados que permitia o trabalho em grupo. 
para suprir as necessidades individuais. A cápsula seria entendida como um equipamento pré-fabricado industrialmente, combinando partes variadas e estandartizadas. Promovia uma qualidade no significado dos edifícios, através da possibilidade de modificação das partes, tornando-se um novo objeto. A proliferação seria possível pela adição de componentes e unidades funcionais como cozinha e banheiro (KUROKAWA, 1977, p. 83).

A produção em larga escala dos espaços de morar era a forma pela qual os arquitetos e a construção civil encontraram para atender à população. No comentário de Kurokawa, a ideia era reproduzir a fabricação das cápsulas de forma racionalizada, nos mesmos moldes dos carros, que corriam por uma esteira e eram montados de acordo com a escolha do cliente.

A oitava declaração apontava que cápsula era produzida sob a lógica da não uniformidade e pensamento não sistemático;

[...] Um edifício é dissolvido em partes e é encapsulado como unidades funcionais. Um edifício será definido no futuro, como o estado de acoplagem espacial-temporal de mais de uma cápsula ${ }^{51}$ (KUROKAWA, 1977, p.84, tradução nossa).

Kurokawa fala sobre unidades funcionais e comenta que essas poderiam ser entendidas como fragmentos de ideias e, apontava que a fragmentação da cidade ou da arquitetura em unidades espaciais proporcionava a variedade, a individualidade e as características do metabolismo.

Kurokawa conclui dizendo:

A noção da cápsula não é uma das partes, a cápsula é um componente auto-suficiente, como uma célula viva, uma entidade em funcionamento uma unidade de espaço significativa com seu ciclo de

51 Original em inglês: [...] A building is dissolved into parts and is capsulized as functional units. A building will be defined in the future as the state of spatial- temporal docking of more than one capsule[...] (KUROKAWA, 1977, p.84) 
vida própria. Vive e morre, mas o en ${ }^{52}$ está sempre lá para assumir novas células. Da mesma forma, as cápsulas podem ser transferidas ou destruídas para dar lugar a novas cápsulas. A mudança constante, em termos de tempo e espaço, é a lei do universo chamado metabolismo53 (KUROKAWA, 1977, p.111, tradução nossa).

Verifica-se que Kurokawa estava a par de aspectos emergentes da década de 1960, como por exemplo, quando falava da relação homem-máquina, da mobilidade, da produção para uma sociedade de massa e da industrialização da habitação para corresponder à demanda social. Observa-se também uma busca veemente pela valorização do indivíduo e do individualismo, a partir da justificativa de que esse padrão de vida seria benéfico aos japoneses e inclusive contribuiria para seu crescimento espiritual.

A individualização no decorrer do século XX foi cada vez mais discutida, Kurokawa respondia a essa valorização. Ele considerava a família formada por pessoas individuais e reconhecia os novos agrupamentos familiares. Esses encaminhamentos poderiam ter sofrido influência budista, como mencionado por Charles J encks na introdução do livro Metabolism in Architecture:

\begin{abstract}
Pode-se ver aqui a conexão direta de ciclos de mudança do Metabolismo com a reencarnação budista solicitando o trocadilho que o Metabolismo deve realmente ser chamado de "Metabudismo". Kurokawa contrasta de muitas maneiras as noções estáticas do Ocidente ${ }^{54}$ (JENKS apud Kurokawa, 1977, p. 10, tradução nossa).
\end{abstract}

Como descreve Suzuki (1994), o Budismo, religião não-teísta que tem origem no

52 En significa mídia, local em que há a intercomunicação. (KUROKAWA, 1977, p.111)

53 Original em inglês: [...] notion of the capsule is not one of parts; the capsule is a self-sufficient component like a living cell, a functioning entity a meaningful space unit with its own life cycle. It lives and dies, but the en is always there to take on new cells. Likewise, his capsules may be moved or destroyed to make room for new capsules. Constant change, in terms of time and space, is the law of the universe called metabolism (KUROKAWA, 1977, p.111).

54 Original em inglês: One can see here the direct connection of Metabolism cycles of change with Buddhist reincarnation prompting the pun that Metabolism should really be called 'Metabuddhism'. Kurokawa contrasts it in so many ways with the static notions of the West. (JENKS, C. , apud Kurokawa, 1977, p. 10) 
ser individual, acredita na consciência do indivíduo e na transformação do mundo através da meditação solitária - melhorando a si mesmo modificaria o seu entorno e consequentemente o mundo. Percebia-se, portanto, que para Kurokawa não havia dificuldade em assimilar a individualidade já que suas próprias crenças estavam embasadas na mesma condição budista.

De acordo com as declarações, as cápsulas seriam o habitat apropriado para o homem da década de 1960. Incorporava a mobilidade em seu conceito, propiciava local para o desenvolvimento do ser humano e era conectado com a cidade através dos meios de comunicação. 


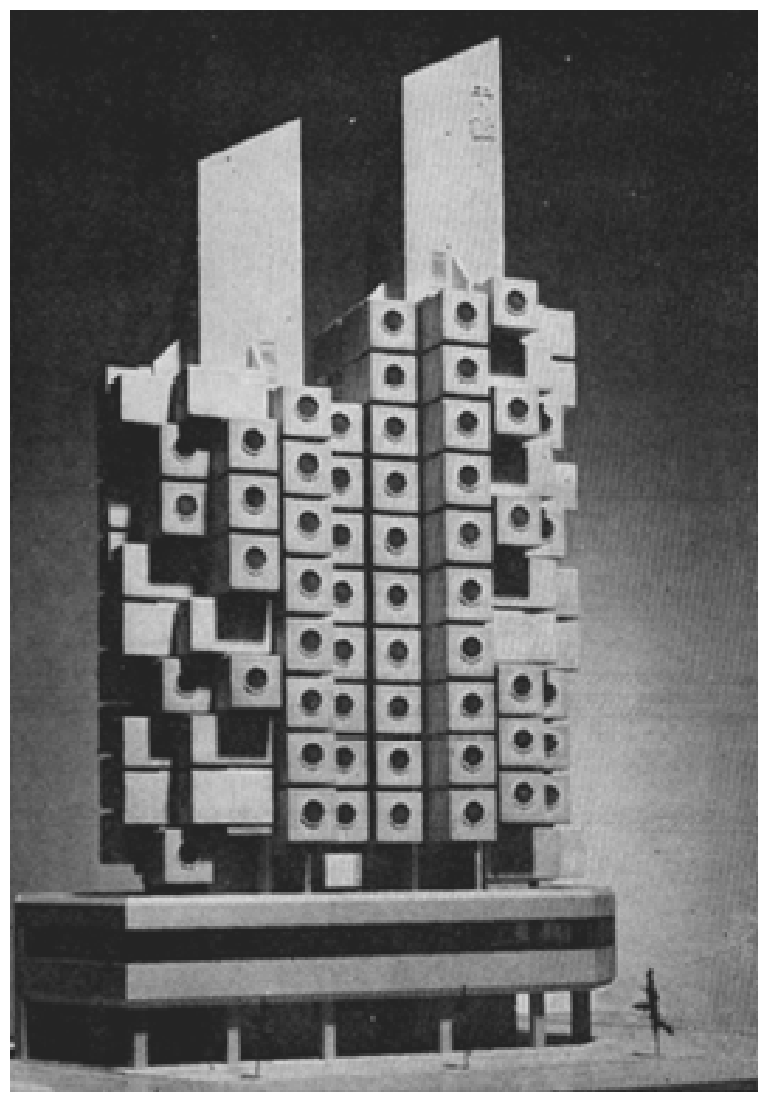

Figura 87: Foto da maquete publicada em 1971. Fonte:

Nakagin Capsule Tower, publicado

na revista The Japan Architect, $v$.

$174,1971$. p. 3. 


\subsection{O Nakagin Capsule Tower}

Talvez um dos mais famosos projetos concretizados de Kisho Kurokawa seja o Nakagin ${ }^{55}$ Capsule Towerlocalizado na área de Ginza em Tokyo, edificado em 1972. Tem quatorze andares com cento e quarenta cápsulas agregadas a uma estrutura central e às instalações.

Era composto por duas torres estruturais de aço, reforçadas com concreto. Elevadores, equipamentos de instalações e, as cápsulas eram conectadas à estrutura. O processo consistia em dois momentos de construção e de assimilação. De um lado a construção das torres e dos sistemas de fornecimento das instalações e de outro a produção e a montagem em fábrica das partes das cápsulas.

A cápsula era concebida como espaço mínimo e pré-fabricado em uma peça, modelada em concreto. Possuía um nicho de dormir, espaço de estocagem, um apoio horizontal de trabalho e refeições, uma cabine de banho e vaso sanitário. Os equipamentos eletrônicos continham telefone, equipamento de som, televisão, refrigerador e ar condicionado.

A luz entrava por uma janela circular, com possibilidade de escurecer o espaço através de um dispositivo semelhante a um leque. Kurokawa previu utensílios como lençóis, cobertores e escova de dentes, projetados especialmente para o Nakagin.

Os designers resolveram ampliar a natureza das cápsulas de apartamento incluindo neles mais facilidades de escritórios de trabalho e de prestação de serviços oferecidas por hotéis. Estas considerações foram a base dos projetos das cápsulas individuais. Eles contêm uma cama e roupa de cama, espaço de armazenagem para roupas, mesa para trabalho, banheiro com todas as instalações sanitárias, telefone, equipamentos de áudio, e itens de serviços, tais como, lençóis,

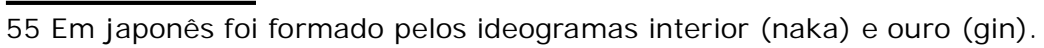




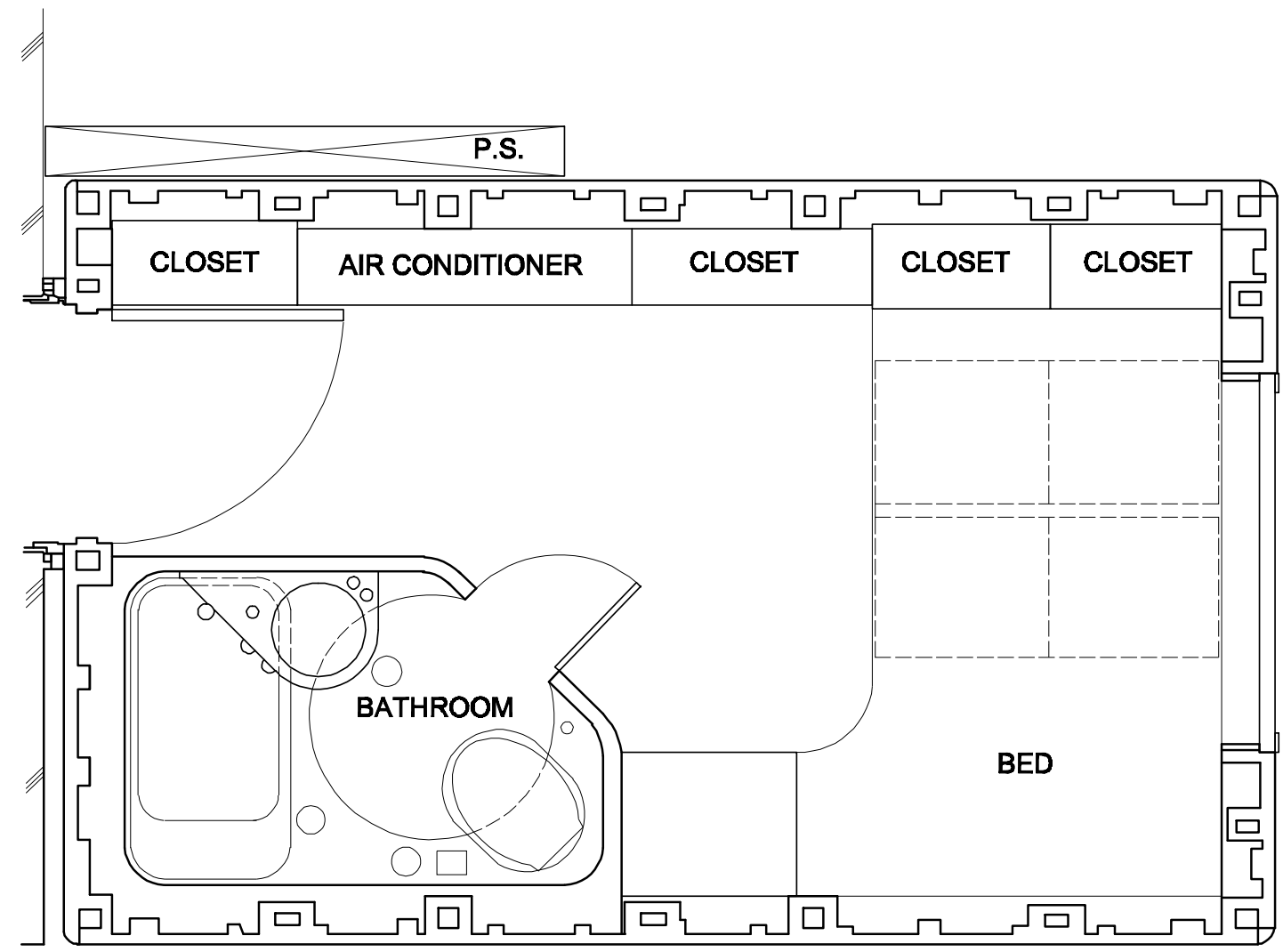

Figura 88: Planta da cápsula

Nakagin Business . Fonte: The

Japan Architect, oct 1972. p. 29.

Reprodução do desenho: Camila

Borghezan 

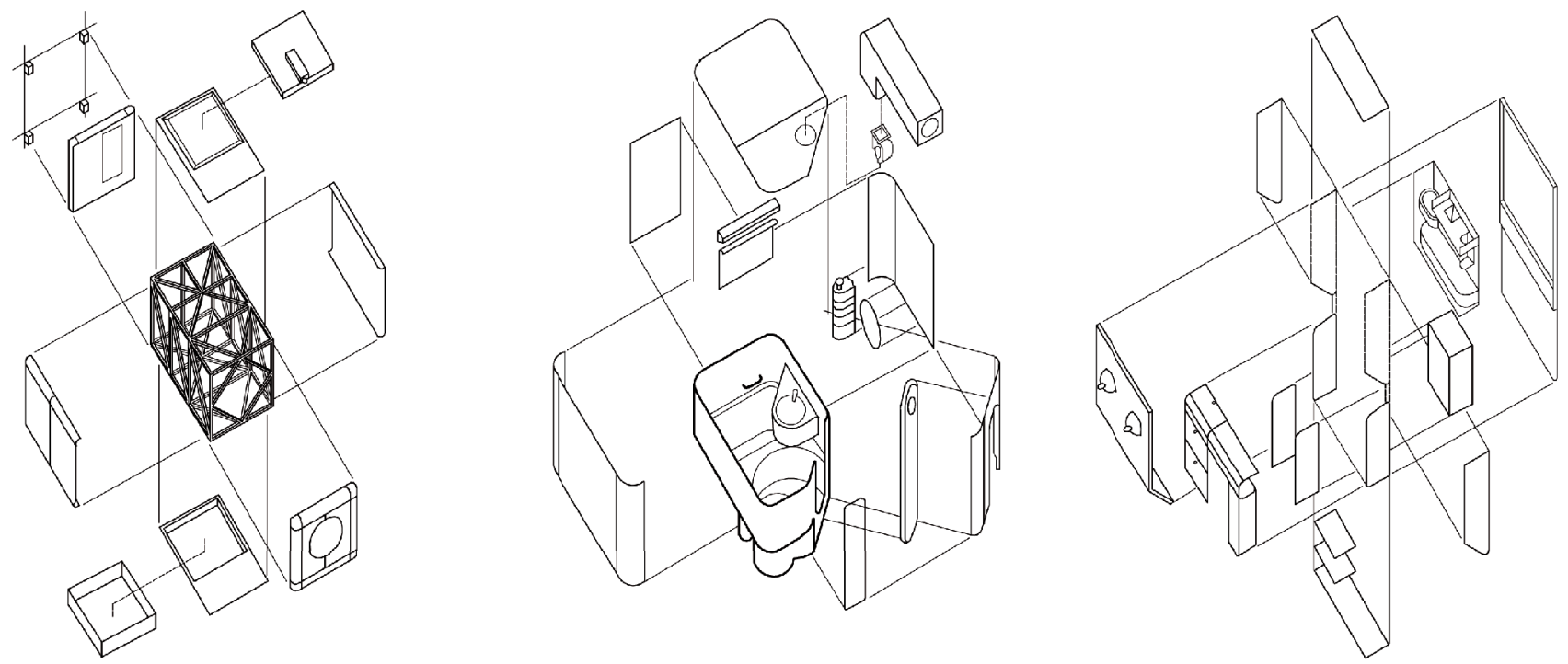

Figura 89: Componentes do corpo e estrutura; banho e ar condicionado. Fonte: The Japan Architect, octo ber, 1972.p. 29. Reprodução do desenho: Camila Borghezan 


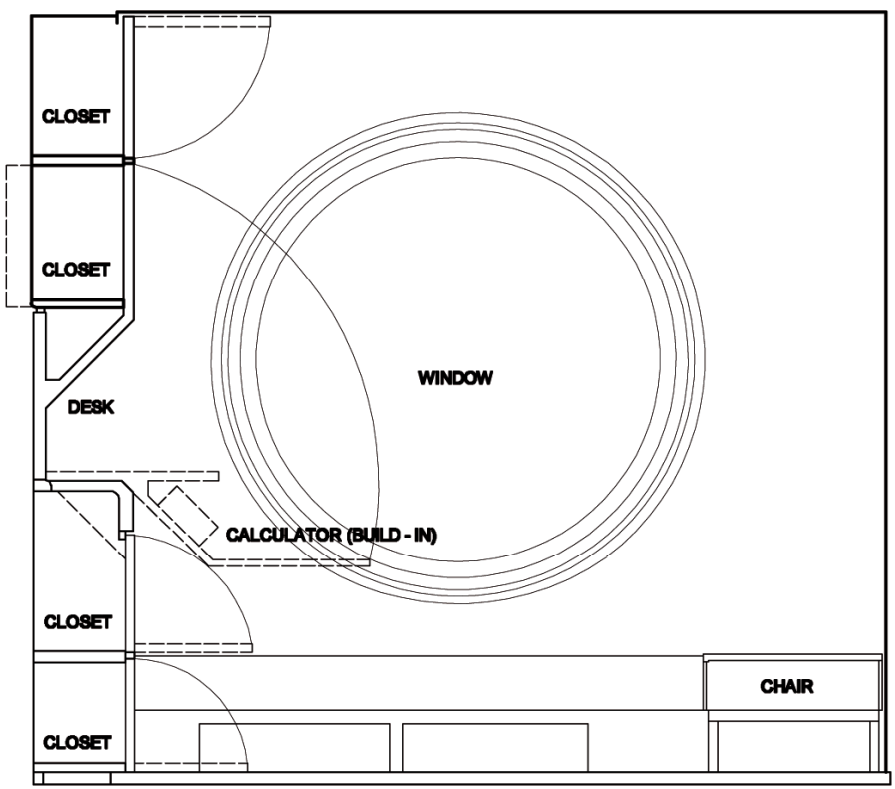

Figura 90: Corte da cápsula

Nakagin Capsule Tower. Fonte:

The Japan Architect, oct, 1972.p.

27. Reprodução do desenho:

Camila Borghezan 


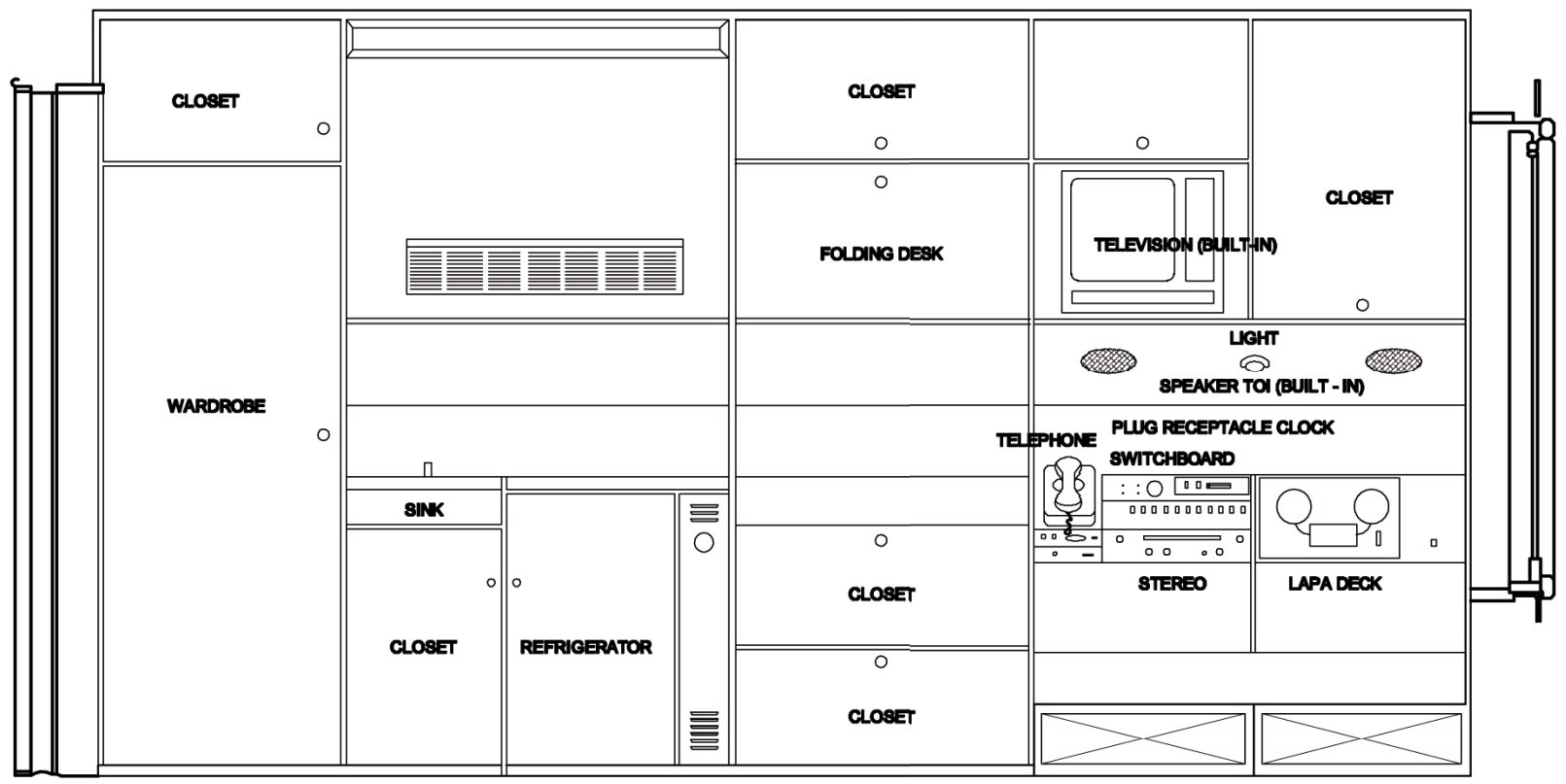

Figura 91: Corte da cápsula Nakagin Capsule Tower. Fonte: The Japan Architect, oct, 1972.p. 27. Reprodução do desenho: Camila Borghezan 
cobertores e escovas de dentes ${ }^{56}$ (KUROKAWA, 1972, p. 24).

As variações de posições de entrada e janela produziram quatro tipos de cápsulas [...] O resultado total foram oito corpos estruturais, duas estruturas articulares, quatro estruturas de encanamentos, oito tipos de unidades de casa de banho ${ }^{57}$ (KUROKAWA, 1972, p. 24, tradução nossa).

Segundo Kurokawa (1972), as cápsulas seriam encaminhadas por caminhões quando a estrutura estivesse pronta. Os encanamentos eram conectados a tubos flexíveis. A parte inferior das cápsulas possuía área de visita para reparos e checagem. (KUROKAWA, 1972, p. 25)

$\mathrm{O}$ arquiteto aponta que a primeira fase consistia no projeto básico que se concentrava na funcionalidade e habitabilidade da cápsula. A segunda fase do processo, previa a verificação da disponibilidade das peças, apesar de serem substituíveis nesse início. Quando as partes fossem unidas, haveria a necessidade de coordenar a produção com os desenhos, ao mesmo tempo em que a fábrica deveria estar bem orientada em relação à utilização das peças. Ao mesmo tempo, as diversas etapas como estrutura básica, transporte, planejamento necessitavam de cuidados minunciosos.

Era necessária uma catalogação para o gerenciamento e atividades conectadas com as cápsulas. Eram divididas em partes de três categorias: partes abertas, partes essenciais e partes especiais (open parts, pure parts e special parts).

56 Original em inglês: The designers resolved to amplify the apartment nature of the capsules by including in them more facilities for office work and by providing services of the kinds afforded by hotels. This considerations formed the basis of the disegn of the individual capsules. The contain a bed and bedding, storage space for clothing, a desk for office work, a bathroom that includes all sanitary facilities, telephone, audio equipment, and such service items as sheets, blankets, and even toothbrushes. (KUROKAWA, 1972, p. 24)

57 Original em inglês: [...] Variations of entrance and window positions produce four capsule types. [...] The resulting total is eight structural bodies, two joint structures, four piping structures, eight kinds of bathroom units. (KUROKAWA, 1972, p. 24). 
[...] Partes abertas [open parts] são aquelas encontradas em catálogos em geral. Incluem acabamentos para o propósito dessas cápsulas, os objetos tais como televisores e computadores. Partes puras [ pure parts] são aquelas que, foram projetadas para todos os tipos de cápsulas e fazem parte da linha de produção e estoque. Na seleção de peças para cotejar as partes para as cápsulas, tendemos usar algumas Partes abertas [ open parts] e muitas Partes especiais [ special parts] são aquelas que foram projetadas para o uso em cápsulas especiais ${ }^{58}$ [...] (KUROKAWA, 1972, p. 28, tradução nossa).

Em entrevista Kurokawa (1972) praticamente descreveu o processo de elaboração do objeto e quais as suas relações entre o desenho e o processo fabril. Descreveu o processo racional e o consequente esforço de gestão necessária para conjugar ambos. E o resultado final era o objeto como produto, o edifício constituído pela sua estrutura, conectores e cápsulas.

Quando Kurokawa falava das cápsulas, pensava em funcionalidade, habitabilidade da cápsula e no mercado consumidor. Essa relação estava ligada à utilização do equipamento, mas também nas possibilidades de materiais e serviços que o mercado oferecia.

Kurokawa (1972) aborda os diversos aspectos da coordenação entre projeto, produção industrial e montagem em canteiro de obras. A experiência de produzir cápsulas que fossem substituídas quando se tornassem obsoletas necessitaria que a produção de fábrica fosse subsidiada por um mercado consumidor contínuo, o que não era tarefa fácil. Para que isso acontecesse, seria necessário uma disseminação desses exemplares em muitos outros edifícios, e não somente em um único caso como o Nakagin. Dessa forma, essa intenção estava destinada ao

58 Original em inglês: [...] Open parts are those found in general catalogs. They include finishings and, for the purposes of these capsules, such things as television sets and table computers. Pure parts are those that, having been designed for the capsules, are used in all capsule types and are on the production and stock line. In selecting collating parts for the capsules, we tended to use some open parts and many pure parts. Special parts are those that have been designed for use in special capsules [...](KUROKAWA, 1972, p. 28). 
fracasso.

O Nakagin Capsule Tower tem um desenho consideravelmente ocidentalizado, a não ser pela presença do ofurôno banheiro e pela elaboração da célula que utilizou o tatamicomo dimensão do módulo. Todos os equipamentos, tais como escrivaninha, ammários, cama, e a exclusão da área para tirar sapatos foram desenvolvidos como ocidentais, elevados do chão utilizando cadeiras ou cama. diferente dos costumes japoneses que utilizariam acolchoados. Sendo assim, é possível observar como Kurokawa trabalhou as influências em seus projetos de acordo com os modos de vida ocidentais. 


\subsection{A Casa Bola No Brasil}

Se no J apão Kurokawa trabalhava a ideia de cápsula, no Brasil esse conceito poderia ser representado pelo exemplo da Casa Bola do arquiteto Eduardo Longo. De acordo com a professora Edite Caranza (2004), Eduardo Longo ${ }^{59}$ trabalhou na busca de unidades para produção seriada e anexáveis em estruturas independentes desde sua formatura.

O arquiteto possui vários projetos na área residencial, inclusive diversos projetos como as Casas Bola, tais como as Bolas Voadoras, ensaio de 1980, estudo Sobrebola São Paulo de 2007 (fig 92 e 93).Peruíbe/ Amauri, construído 1974-1979 (fig 94), Casa Bola Rua Gália São Paulo, construído em 1980, .

Caranza (2004) afirma que no final da década de 1960 Eduardo Longo conheceu projetos de Buckminster Fuller, Archigram e dos Metabolistas, a partir dos quais passou a pesquisar e aplicar aqueles conceitos em suas obras.

Segundo Caranza, na década de 1960,

Longo se dedicou ao estudo da arquitetura para se aperfeiçoar. Estudou melhor o trabalho de alguns arquitetos, como por exemplo: o grupo dos metabolistas japoneses, os ingleses do Archigram, Yona Friedman e o trabalho do norte-americano Buckminster Fuller. (CARANZA, 2004, p. 157)

A primeira proposta de Casa Bola ${ }^{60}$ foi realizada em 1972, construída sobre o escritório do arquiteto. Foi pensada para ser executada a partir de um processo industrializado, ser acoplada a uma estrutura metálica deixando o chão livre ocupando o espaço aéreo. A estrutura metálica foi feita com tubos, e o fechamento em argamassa-armada (CARRANZA, 2004).

59 Formou-se na Universidade Presbiteriana Mackenzie em 1966.

60 Longo possui vários projetos com a tecnologia "Bola". Disponível em: <http://longoeu.sites.uol.com.br/> acesso em 09 jan 2011. 


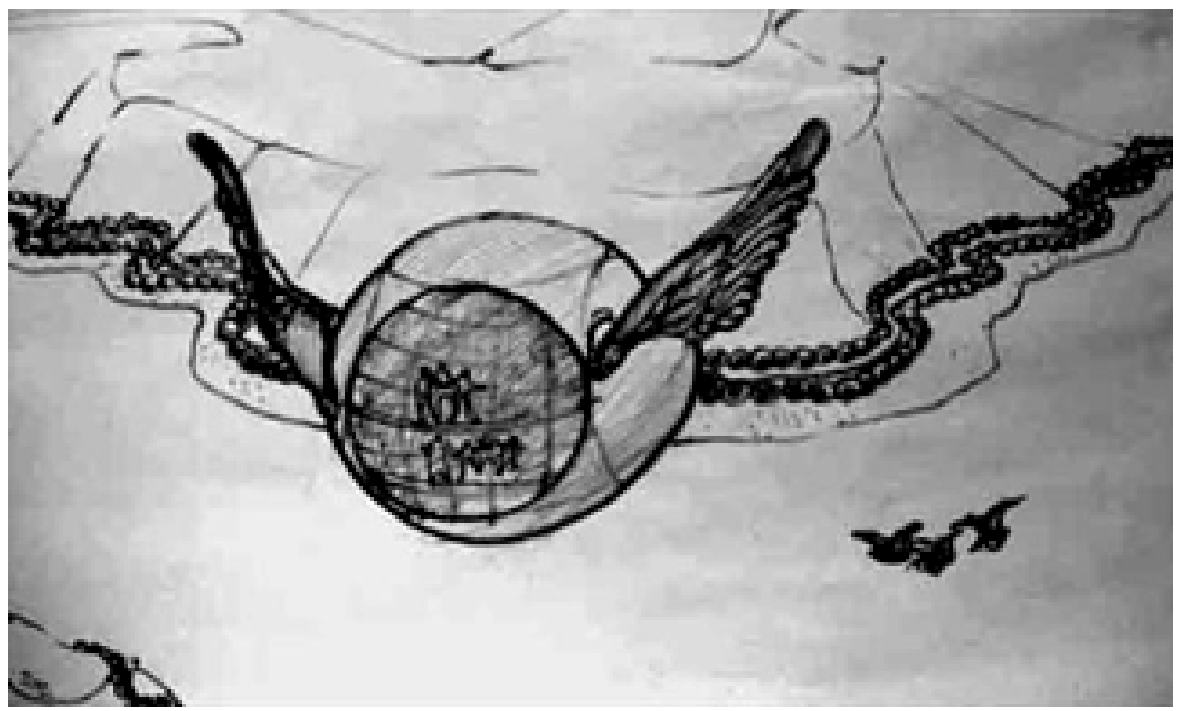

Figura 92: Bolas voadoras, (1980)

Eduardo Longo. Bolas voadoras,

(1980) Eduardo Longo. Fonte:

Disponível em: «ttp://www.

eduardolongo.com/bolBV2.html>.

Acesso em: 28 set 2010. 


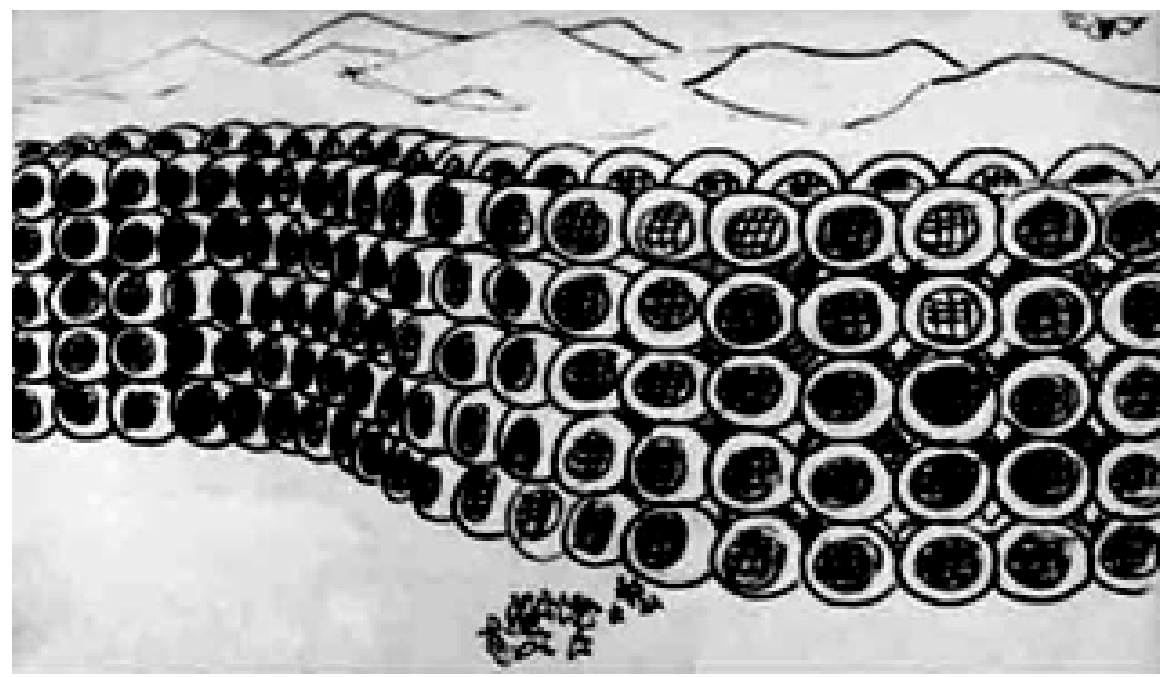

Figura 93: Bolas voadoras, (1980)

Eduardo Longo. Bolas voadoras, (1980) Eduardo Longo. Fonte:

Disponível em: ‘http://www.

eduardolongo.com/bolBV2.html>. Acesso em: 28 set 2010. 

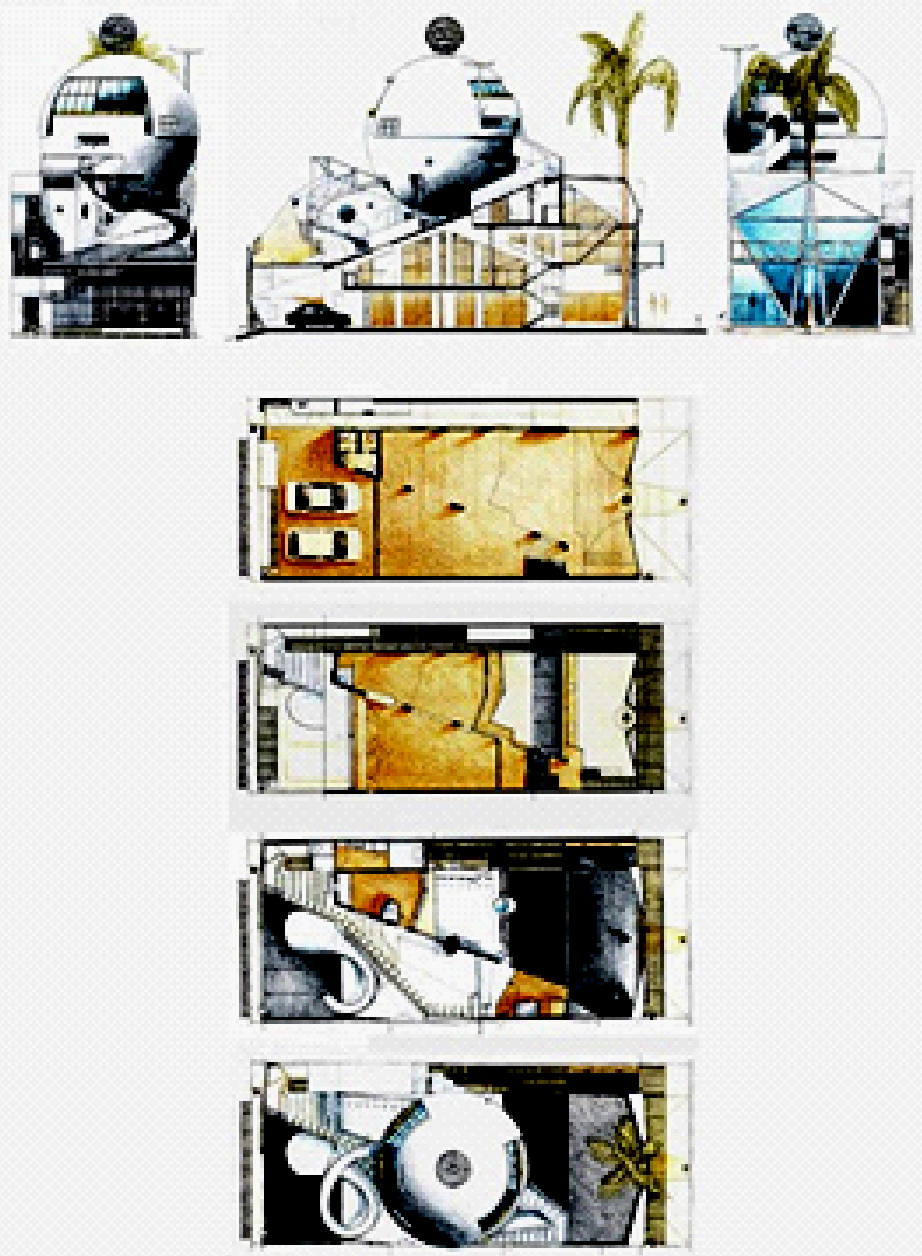

Figura 94: Peruíbe/Amauri (1972) Eduardo Longo. Peruíbe/Amauri (1972) Eduardo Longo . Fonte: Disponível em: «ttp://longoeu. sites.uol.com.br/pa70-04.html?. Acesso em: 28 set 2010. 
A casa possuía um programa dividido em três áreas; íntima, social e de serviço: com três suítes, lavabo, sala de jantar, sala de estar, cozinha, quarto de empregada e lavanderia. O mobiliário da casa fazia parte do projeto e foi moldado também em argamassa-armada, tais como as camas, os armários e as mesas. A bancada da cozinha possuía uma mesa, uma pia, fogão, geladeira e armário; o compressor da geladeira foi locado na lavanderia para ajudar a secar as roupas. $O$ arquiteto Longo parece ter absorvido a ideologia das megaestruturas da década de 1960, contudo sem conseguir concretizá-las. Tanto a produção industrial das Casas Bola como a produção das megaestruturas em sistema fabril tornaram-se inviáveis naquele momento.

A produção da Casa Bola enquanto espaço do habitar foi formulada para se constituir como uma cápsula, como um abrigo, parte de um sistema maior, de uma megaestrutura urbana, pensada como um equipamento da cidade. Ela consegue ter um detalhamento que se preocupa com o mobiliário desenhado e solucionado junto com a arquitetura. Contudo utiliza para isso a argamassa-armada que é um material plástico, porém pesado. Outro aspecto questionável é que a casa segue um programa subdividido em cômodos funcionalmente estanques, seguindo um modelo burguês de habitação. Isso difere das cápsulas cujo espaço era concebido onde as atividades são pensadas sobrepostas em um espaço mínimo, o que representou uma ruptura em relação ao modelo burguês.

Pode-se considerar, portanto, que a Casa Bola foi uma tentativa que se resumiu a uma solução formal, praticamente realizada artesanalmente. Seu projeto foi adequado à situação da família brasileira, de classe média, conforme foi citado no trabalho de Carranza (2004):

Longo projetou a Casa Bola 1 seguindo o programa de um apartamento destinado a uma família de classe média, para "um esquema de vida convencional" segundo ele, com a seguintes dependências: três suítes, lavabo social, sala de estar, quarto de empregada e lavanderia 


\subsection{Considerações}

As cápsulas eram vistas como espaços do habitar e seriam consideradas como parte da cidade compreendida como habitat. Cumpririam a função de moradia e as diferentes funções complementares seriam proporcionadas por outros elementos da cidade.

As cápsulas como moradia individual têm um forte apelo para responder à organização de uma sociedade, resultante do elevado consumo e de acordo com o avanço das tecnologias emergentes da ciência. Elaboradas para promover a mobilidade e a agilidade, vistas como aspectos fundamentais ao homem de 1960.

Kisho Kurokawa foi um dos principais atuantes do movimento Metabolista que era uma antítese ao movimento moderno. Trazia como conceito a aproximação com a biologia, que tinha a capacidade de modificação constante e a estratégia de metamorfose, para se adaptar a uma nova condição. Essa foi a base para toda sua teoria a respeito do Metabolismo.

Sobre as influências, observa-se que a discussão que travou com seu professor Kenzo Tange durou mais de uma década, mas é inegável a sua influência no movimento posterior dos Metabolistas e, em particular, em Kisho Kurokawa.

De Buckminster Fuller, Kurokawa herdaria o raciocínio industrial de produção. Dos Smithsons a ideia da casa dentro da lógica da Arte Pop, para uma sociedade de consumo e influenciada pela informação veiculada nas mídias. O surgimento das cápsulas submarinas e espaciais provaram, para Kurokawa e para o mundo a possibilidade de viver autonomamente a simbiose entre homem e máquina.

De acordo com Masuda (1982), os líderes japoneses acreditavam na importância da disseminação da informação, isso contribuiu para que o J apão investisse em 
tecnologia, nos mecanismos de controle e comunicação.

A proposta de Kurokawa para Tokyo, no ano 2025, tem grande afinidade com o projeto de Cedric Price para a universidade Potteries Thinkbelt, que foi elaborado com bases na cibernética, demonstrando a aproximação de Kisho Kurokawa aos conceitos cibernéticos.

Observa-se a intenção de pensar em um sistema de comunicação parecido com a internet. Apesar do esforço de Kurokawa em valorizar a tradição e a cultura japonesa, considera-se que o Nakagin Capsule Towertem um desenho consideravelmente ocidentalizado, a não ser pela elaboração dos módulos de tatamie a presença do ofurô, todos os demais equipamentos não demonstrariam o design tradicional da cultura japonesa.

Kurokawa expôs os aspectos relevantes em relação ao processo de design e a execução do objeto em canteiro, fábrica e desenho. Deu possibilidade de escolha para o usuário e materializou a proposta. As cápsulas foram elementos viabilizados no J apão e provavelmente responsáveis pelos atuais containers de higiene inseridos nas habitações e as cápsulas existentes como hotéis de curta permanência.

Considera-se que Kurokawa é um dos principais arquitetos representantes da cisão com a arquitetura moderna no J apão, que assimilou os modos de vida ocidentais, a valorização da individualização em detrimento da família tradicional e a utilização das teorias emergentes da cibernética, explicitadas nas cápsulas do Nakagin Capsule Tower.

A concretização dos modelos de cápsulas demonstraram a assimilação dos japoneses a esse modelo de habitat. Esse habitat era elaborado para ser espaço individual, mínimo, que cumpriria as necessidades básicas e propício para o homem móvel, produto de uma sociedade de massa e contemporâneo. 


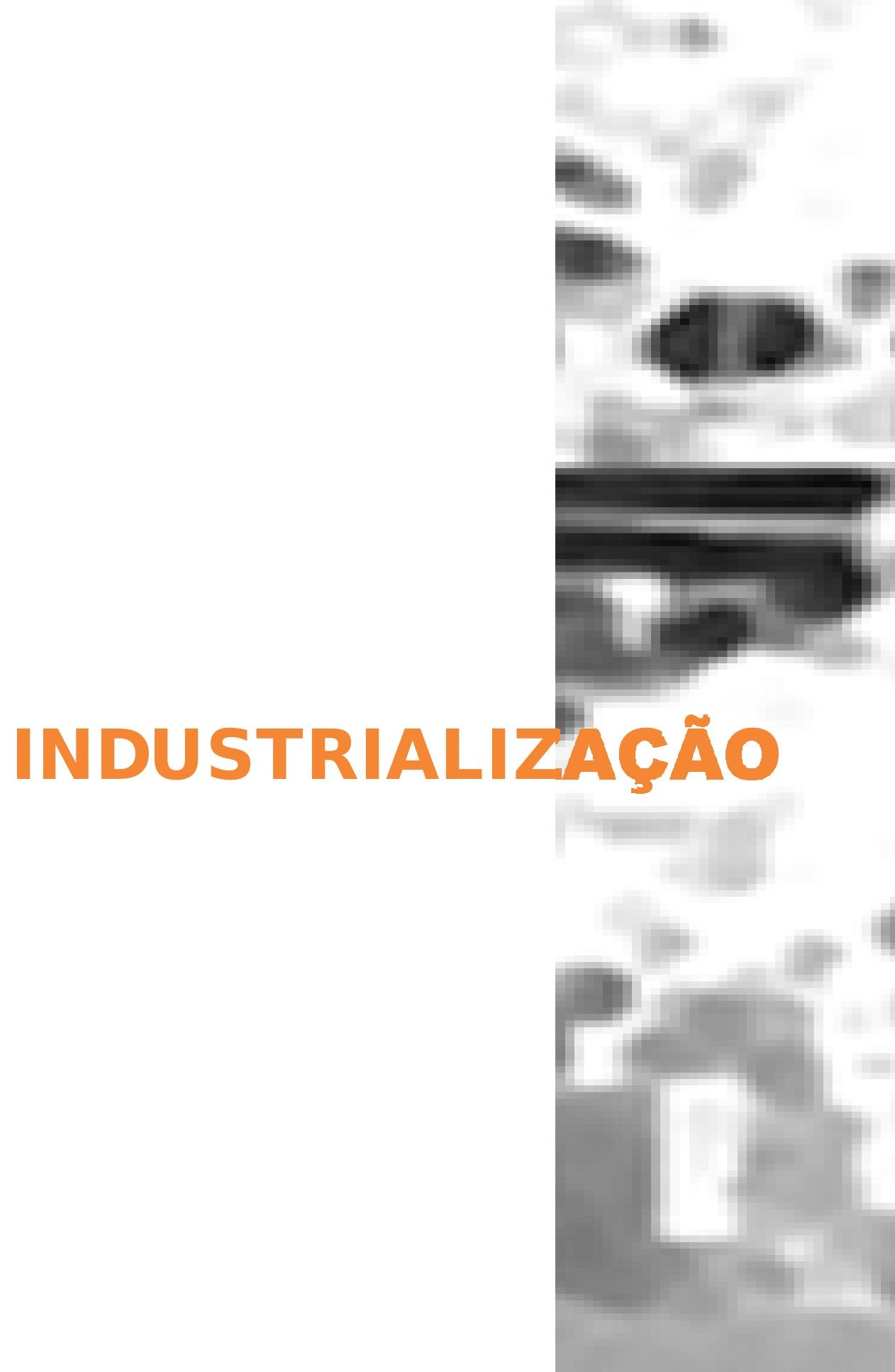


Neste capítulo destaca-se o intuito de aproximação de mais um princípio norteador do habitat: o do fazer. A seleção do arquiteto J oão Filgueiras Lima para discutir a industrialização como meio para a construção do habitat na década de 1960, se deu por suas proposições e experiências profissionais na área de pré-fabricação na construção civil já a partir do período analisado neste trabalho.

A produção em série utilizada como meio para construção do habitat, que foi revisada nos meados da década de 1960, era compreendida por J oão Filgueiras Lima como, ao mesmo tempo um instrumento para atingir uma equidade e também resultado de uma consciência social e coletiva, recorrente nos países subdesenvolvidos e, particularmente, no Brasil.

Realiza-se a contextualização da industrialização da construção civil e abordamse aspectos característicos dessa temática, tais como a Coordenação Modular, a compreensão do Ciclo Aberto e Fechado, a racionalização e os custos da construção. É citado como exemplo o arquiteto J oão Filgueiras Lima (Lelé) que trabalhava a arquitetura como um dos meios de democratização da adequada qualidade de vida para a população brasileira.

Descreve-se ainda sobre a Teoria Geral de Sistemas, por considerar que essa teoria possibilite uma análise sobre o trabalho de Lima e por ter sido utilizada em vários campos do saber. Aborda-se também o conceito de habitat focado pelo arquiteto, e quais os envolvimentos ideológicos e políticos no Brasil que envolviam a criação da Universidade de Brasília da qual ele fez parte.

\subsection{Contextualização Histórica}

De acordo com Paulo Bruna (1970), a pré-fabricação na construção civil já estava presente na Inglaterra no século XIX, início da Revolução Industrial. As estruturas metálicas fabricadas eram exportadas para os Estados Unidos e América Latina. No 

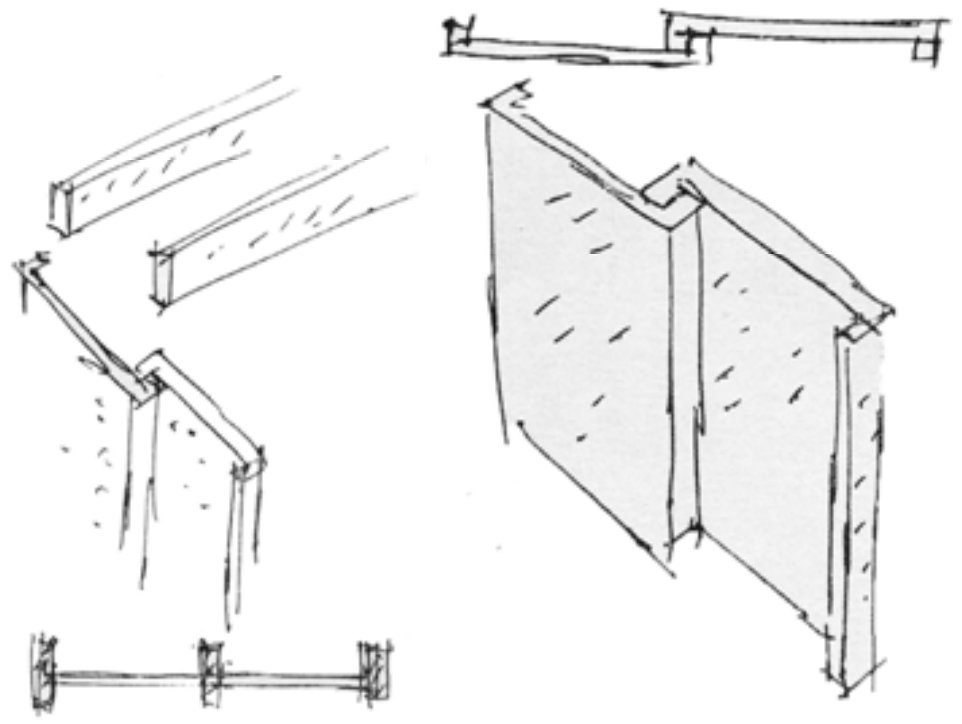

Figura 95: Desenho de divisórias

- Oscar Niemeyer. Fonte:

(NIEMEYER, 1963, p. 27).

198 


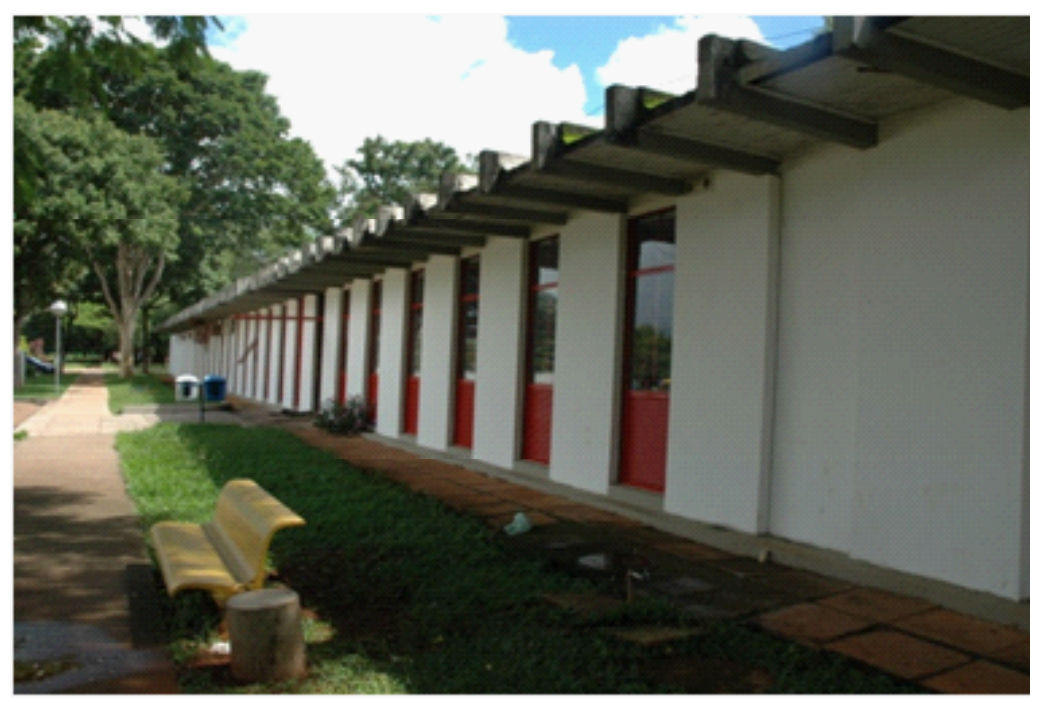

Figura 96: Ceplan. Foto: Acervo Pessoal, (30/12/2010) 

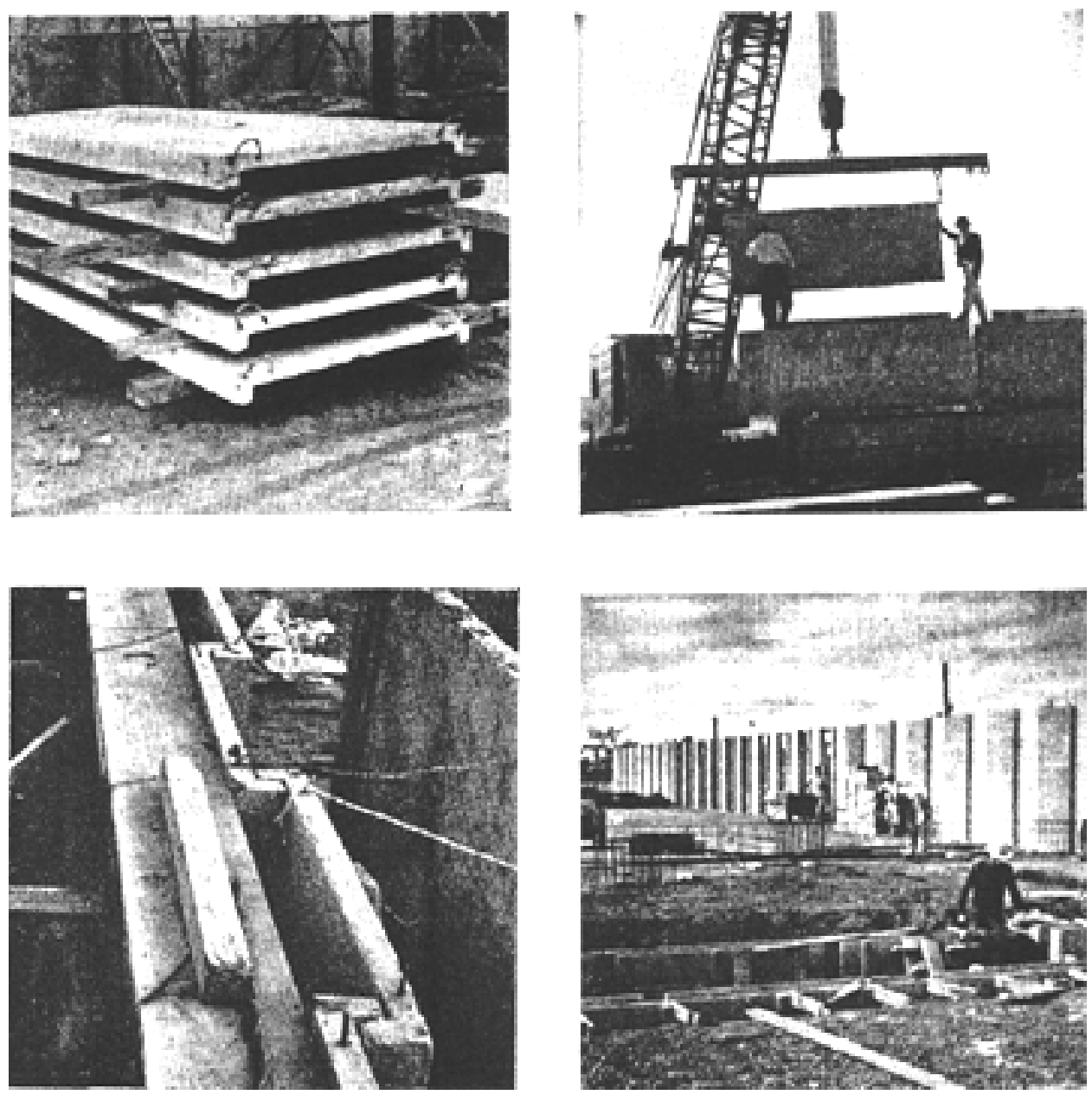

Figura 97: Fotos da montagem e canteiro de obras Ceplan. Fonte: (NIEMEYER, 1963, p. 27). 
Brasil, são exemplos dessas estruturas a Estação da Luz e o Viaduto do Chá em São Paulo. Bruna ainda aponta que o arquiteto e diretor da Bauhaus ,Walter Gropius, percebia desde 1924, a necessidade da produção em massa de habitações, e defendia que poderiam ser produzidas em fábricas na forma de componentes.

O desenvolvimento industrial da construção civil na Europa após a Segunda Guerra Mundial, foi decorrente de três fatores: 1 . a necessidade urgente de novas habitações em decorrência da destruição causada pela guerra e o saneamento de áreas degradadas; 2 . a necessidade de investimentos para o desenvolvimento de tecnologias que minimizassem o custo das construções e, 3 . a necessidade de mão-de-obra especializada (BRUNA, 1970).

O registro da pré-fabricação na construção civil estava intimamente ligado ao período de industrialização e de mecanização, como observam Serra, Ferreira e Pigozzo (2005),

O sistema pré-fabricado se identifica primeiramente com a história da industrialização, que por sua vez está relacionada com o período histórico da mecanização, ou seja, com a evolução das ferramentas e máquinas para produção de bens. De forma gradativa as atividades exercidas pelo homem com auxílio da máquina foram sendo substituídas por mecanismos, como aparelhos mecânicos ou eletrônicos, ou genericamente por automatismos (SERRA, FERREIRA \& PIGOZZO 2005, p. 3).

A industrialização trazia vários benefícios, tais como a economia pela produção racionalizada, o tempo de execução e o aprimoramento em relação às sucessivas repetições do mesmo produto. Porém as críticas relacionadas à industrialização associavam a monotonia da arquitetura produzida pela construção industrializada e o aspecto desumano dos ambientes caracterizados pela repetição de linguagens produzidos por esses tipos de projetos.

No Brasil, o período do governo do presidente J uscelino Kubitschek (1956-1961) 

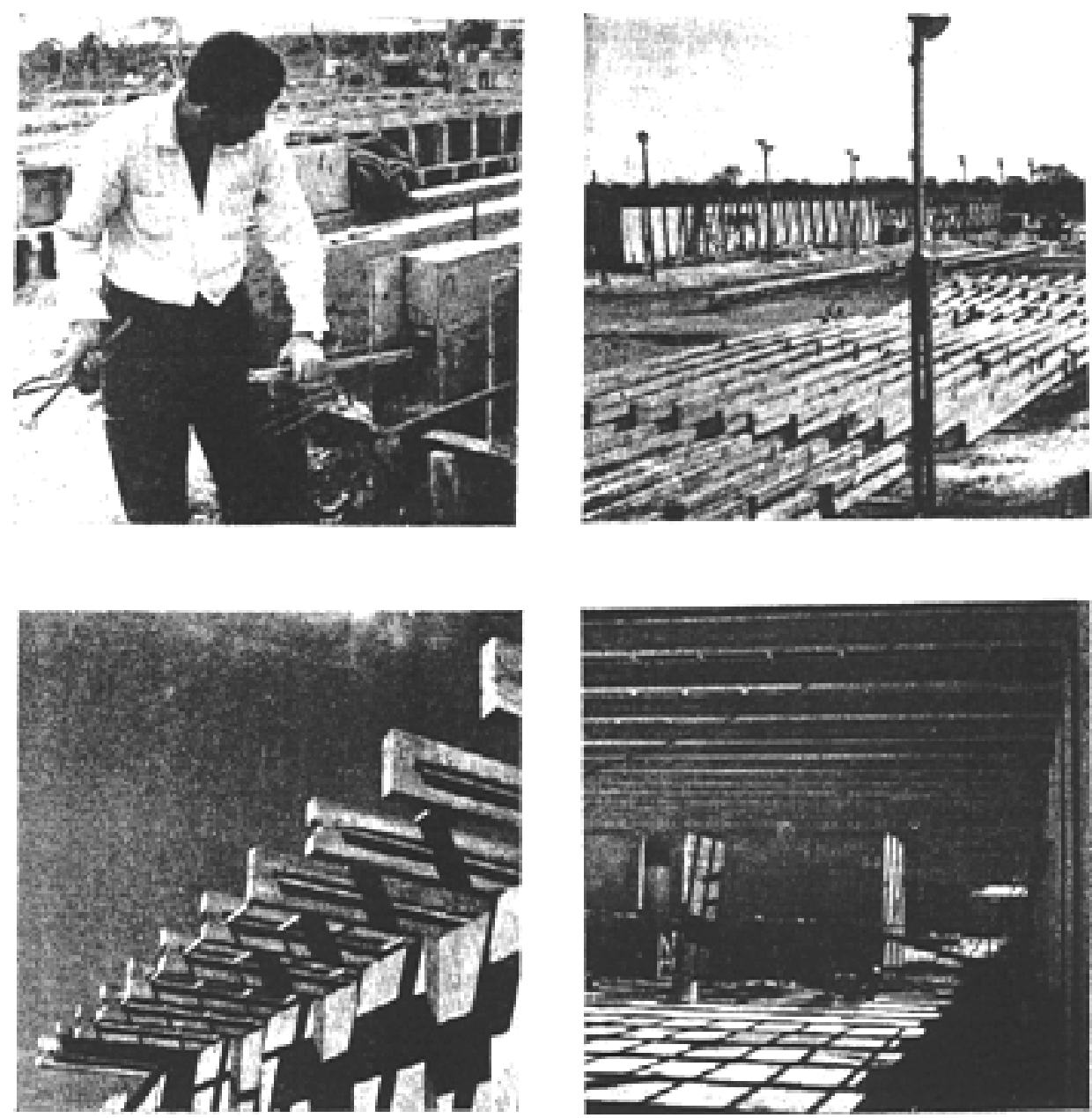

Figura 98: Canteiro de obras

Ceplan Fonte: (NIEMEYER, 1963,

p. 27). 
priorizou a expansão do setor industrial com a construção da nova capital no centro geográfico do país, a abertura de rodovias para a integração do território nacional, a indústria de base e a indústria automobilística. $O$ aumento da capacidade energética eram temas de um conjunto de metas que objetivavam promover, a partir de um determinado projeto de modernização nacional, uma grande era de desenvolvimento em um curto espaço de tempo (KOURY, 2007, p. 190).

A construção civil no Brasil, na década de 1960 e 70, poderia ser descrita em três tipos de iniciativas: a primeira do setor industrial que cobrava do Estado uma política para a industrialização que deveria ser conduzida pelo setor privado; a segunda que tinha o Estado como regulador do investimento privado e a terceira que utilizava materiais disponíveis no mercado para a autoconstrução e que seria auxiliado pelo conhecimento técnico do arquiteto (KOURY, 2007). Lima fez parte da segunda corrente, que tinha o Estado como regulador e incentivador das tecnologias desenvolvidas na construção industrializada.

A construção do Ceplan (Centro de Planejamento Oscar Niemeyer) em Brasília, projeto de Oscar Niemeyer, foi um dos primeiros edifícios pré-fabricados no Brasil. Publicado na revista Módulo em 1963, o edifício foi elaborado com vigas protendidas de concreto pré-moldado e montagem por içamento dos elementos, e se estruturava na junção dos painéis com as vigas, como mostram as figuras 95 a 98.

Conforme depoimento de Niemeyer, o Ceplan tinha em vista uma,

[...] ação atualizada e uniforme. [...] baseado nos sistemas modernos de pré-fabricação, visando construções rápidas e econômicas (NIEMEYER, 1963, p. 26).

A história da industrialização no Brasil se mescla com a de J oão Filgueiras Lima e com a construção de Brasília. As primeiras experiências de racionalização da construção com peças pesadas de concreto pré-moldado in loco, montagem 
utilizando gruas e grandes vãos, coincidem com os incentivos desenvolvimentistas de J uscelino Kubitschek, no final da década de 1950, identificados com o seu lema de fazer "50 anos em 5".

Por tal motivo, estudar aspectos sobre a produção industrializada desenvolvida por Lima parece importante para dar base ao conceito do habitar pelo ponto de vista da produção através da industrialização.

\subsection{Aspectos intrínsecos da industrialização}

Alguns aspectos sobre a construção industrializada no Brasil precisam ser considerados. De acordo com Rosso (1969), para a aplicação do método industrial:

[...] O que se pretende é conseguir que o processo se desenvolva de forma contínua, uma vez que esta é a condição "sine qua nor" para uma produção em série [...] (ROSSO, 1969, p.36).

Industrializar significa produzir um objeto de forma seriada, sistematizada e racionalizada. Para que a produção industrializada produzisse em seu potencial máximo, e consequentemente diminuísse os custos, era essencial: a continuidade de mercado para consumir os produtos, a continuidade das equipes que atingiriam a especialização do modo de fazer e a continuidade das técnicas utilizadas nas peças.

O aprimoramento da produção industrializada de Lima teve início na construção das quadras 108 e 109 de Brasília (1956), passou pelos alojamentos de Colina (1962), Hospital de Taguatinga (1968), Escolas de Abadiânia (1982-1984), Fábrica de Escolas e Equipamentos Urbanos do Rio de J aneiro (1984-1986), Fábrica de Equipamentos Comunitários (1985-1989) e Centro Integrados de Ensino - CIACS (1990).

Lima foi responsável pelo início da execução das habitações de Brasília, e nessa 
ocasião iniciou suas primeiras experiências na área de produção seriada. No depoimento dado por Lima a Guimarães (2003), ele disse:

[...] Nós montamos em nossa superquadra uma indústria de carpintaria para fazer as portas, para fazer tudo. [...] (LIMA, 2003 apud GUIMARÃES, 2003, p. 15).

Ekerman (2005) narra que a necessidade de industrialização veio já nos primeiros enfrentamentos do canteiro em Brasília. Lima sentira a necessidade de construir rapidamente alojamentos provisórios de madeira para abrigar os trabalhadores. A forma de produzir com agilidade e em série se enraizava na metodologia de trabalho do arquiteto e se especializaria no seu processo ao longo de sua carreira. Dessa forma este trabalho apresenta alguns exemplos, desenvolvidos por Lima e, discute alguns conceitos para entender o processo de produção industrializada.

\subsubsection{A Coordenação Modular e o Ciclo Aberto ou Fechado}

Um dos conceitos básicos para a construção industrializada são: a Coordenação Modular e o Ciclo Aberto ou Fechado. Em relação a Coordenação Modular, Rosso define módulo como o "divisor comum, que representa o elemento metodológico básico do sistema" (ROSSO, 1969, p.8), e cumpre dois objetivos fundamentais: a padronização para a produção e para o projeto. Conforme Rosso descreve:

O conjunto de regras e de normas estabelecidas com objetivo de aplicar o módulo à construção de edifícios, damos o nome de coordenação modular: esta é portanto uma aplicação específica do método industrial por meio da qual estabelece-se uma dependência recíproca entre produtos básicos e intermediários de série (elementos) e produtos finais (edifícios) mediante o uso de uma unidade de medida comum (ROSSO, 1969, p.38).

A Coordenação Modular foi fundamental nas obras dirigidas e projetadas por Lima. Ao falar sobre a definição do módulo, Lima afirmou: 
O módulo inclui outras coisas como as corretas dimensões que estabelecem o conforto dos espaços. [...] O módulo deve ser pensado em função da economia dos espaços, o que não significa somente gastar pouco na construção, mas economizar energia e garantir maior eficiência (LIMA, 2007).

Tendo como base essa unidade-módulo, verifica-se outros componentes que foram todos definidos a partir dessa dimensão, como a locação dos pilares, os desenhos das vigas metálicas e os sheds que acompanham o mesmo padrão do módulo.

A Coordenação Modular aplicada nos desenhos das peças que compõem os edifícios foi fundamental para que J oão Filgueiras Lima conseguisse "a integração dimensional das partes padronizadas ou componentes" (ROSSO, 1969, p. 38). E concluiu:

[...] o desenho dos componentes, a técnica de projeto e a técnica de montagem, deverão ser estudadas e adaptadas à outra regra fundamental de que, se os componentes não se integrarem reciprocamente e não se adaptarem perfeitamente ao projeto, sua utilização não será possível, uma vez que qualquer operação de ajustagem e adaptação no canteiro deverá ser evitada (ROSSO, 1969, p.38).

O segundo conceito básico da industrialização é o entendimento de Ciclo Aberto ou Ciclo Fechado. De acordo com Bruna (1976),

A industrialização de componentes destinados ao mercado, e não exclusivamente às necessidades de uma só empresa, é hoje reconhecida como industrialização aberta ou de CICLO ABERTO, por oposição à fechada que consiste em pré-fabricar elementos em função do próprio consumo, nas próprias obras (BRUNA, 1976, p. 60).

De acordo com a definição de Bruna, o processo produtivo criado por Lima fazia parte do Ciclo Fechado, pois a produção das peças não se destinava ao mercado e eram para uso exclusivo das edificações ligadas à fábrica. 
Em relação a esse mecanismo de produção, considera-se que o Ciclo Fechado utilizado por Lima apresenta dois aspectos fundamentais para a determinação desse processo: a entrada dos componentes no mercado de consumo e o controle total da obra.

O primeiro diz respeito a disseminação no mercado da construção civil dos componentes produzidos por Lima. Em vários casos de edifícios construídos pelo arquiteto, a produção dos componentes estava ligada ao poder público, eram fábricas montadas por governos estaduais ou municipais que tinham como objetivo construir edificações como escolas, creches ou hospitais. Não havia interesse em comercializar os componentes, pois eram para uso exclusivo nos equipamentos públicos.

Sobre o segundo aspecto que trata sobre o controle total da obra, de acordo com as análises de Lima, a produção de um componente pré-fabricado diminuiria o custo e possibilitaria um controle maior em relação ao resultado arquitetônico esperado (LIMA, 2007). Os desenhos dos elementos pré-fabricados eram elaborados de forma integrada. A estreita relação entre as peças facilitava tanto sua produção como a montagem do edifício.

De acordo com Rosso (1969), existiam 3 condições essenciais para o sucesso da produção industrializada: "a padronização, coordenação e integração" (ROSSO, 1969, p. 69) e diziam respeito "à forma, às dimensões à qualidade e à técnica de união dos elementos" (ROSSO, 1969, p. 69).

Lima é exemplo dos incentivos de industrialização da construção civil brasileira na década de 1960. Lançando um olhar sobre sua carreira, percebe-se que a experiência iniciada nos Alojamentos de Colina teve continuidade em sua produção ao longo das décadas seguintes levando ao aprimoramento dessa tecnologia. Lima optou por monitorar, experimentar e melhorar cada elemento que compunha a edificação, acompanhou a evolução dos materiais e tecnologias disponíveis para 
avançar nas escolhas mais simples e de menor custo que resultassem em um produto de qualidade.

Como descreve Segawa (2002), quando trata sobre esse período da história brasileira:

[...] a industrialização representava o alvo maior para o pensamento nacional-desenvolvimentista da época. Para essa mentalidade, o domínio de tecnologia própria constituía um atributo objetivo do grau de progresso do país. [...] O emprego de pré-moldados e a busca da pré-fabricação conheceram ensaios no período (em todo Brasil) sem, todavia, ter-se alcançado resolução satisfatória, afora experiências isoladas de alcance restrito (SEGAWA, 2002, p. 149).

\subsubsection{A Racionalização}

Os elementos que envolvem a racionalização da construção civil estão ligados a organização da produção, diminuição dos custos, agilidade de montagem, economia e eficiência de material, entre outros. A industrialização tem sido utilizada, portanto, como uma maneira para atingir esses resultados. Segundo o depoimento de Lima, a escolha pela industrialização tinha como intenção a diminuição dos custos de fabricação, como ele mostra também em depoimento dado a Mendonça:

[...] Se houvesse um sistema racional de construção, a cada três prédios que você faz você poderia fazer mais um. Nem estou falando de industrialização, estou falando só de planejamento, de racionalização da construção para redução das perdas. Para eliminar as perdas mesmo, e ter uma construção absolutamente planejada, só através de um sistema industrializado [...] (LIMA, 2007).

Sobre a questão de custo, outro aspecto importante, associado à racionalização para a industrialização, foi esclarecida por ele: 
A nossa tentativa de Ribeirão ${ }^{1}$ foi fazer um prédio confortável, as unidades, a creche, atendendo às questões básicas com um custo aceitável e isso era o motivo de estar montando uma fábrica, criando uma indústria de apoio² (LIMA, 2010).

Rosso defendeu que a racionalização, para diminuição dos custos, significava diminuir o desperdício de materiais e mão-de-obra, com utilização eficiente do investimento, aplicando princípios de "planejamento, organização e gestão" (ROSSO, 1990, p. 33). Já na industrialização era,

A aplicação do método industrial à construção civil com o objetivo de melhorar a sua produtividade, acelerar os tempos de execução e baratear os custos, sem perder de vista o condicionamento social, estético e funcional [...] (ROSSO, 1969, p. 36).

Rosso descreveu o papel dos arquitetos e engenheiros no processo industrial em resolver problemas referentes ao projeto e à produção, e para desenvolver a compreensão de racionalização de um processo de produção como:

[...] um conjunto de ações reformadoras que se propõe substituir as práticas rotineiras convencionais por recursos e métodos baseados em raciocínio sistemático, visando eliminar a causalidade nas decisões (ROSSO, $1990^{3}$, p. 33).

Quando Lima falou em racionalização, associada à diminuição dos custos, podia-se avaliar a complexidade das ações de trabalho envolvidas nesse processo produtivo sob sua coordenação, tendo em vista a elaboração, desenho, produção, execução e pós-avaliação. Lima é hábil em coordenar o trabalho como um todo, desde o desenho até a montagem, passando pela gestão administrativa e de custos, próprias da atribuição do arquiteto.

1 Lima foi contratado pela prefeitura de Ribeirão Preto em 2001-2002 para trabalhar em equipamentos urbanos e fazer uma intervenção em área degradada na cidade.

2 Entrevista concedida a autora em Julho de 2010.

3 Primeira edição data de 1980. 


\subsection{Sobre a vida de J oão Filgueiras Lima}

J oão Filgueiras Lima (n.1932) nascido no Rio de J aneiro, no bairro de Encantado, é conhecido entre os arquitetos brasileiros como Lelé 4 . É também músico ${ }^{5}$, compositor e tocava em bailes na década de 1950. No ensino médio, estudou na Escola Militar e se formou em arquitetura pela Universidade do Brasil em 1955 (atual UFRJ ${ }^{6}$ ). Lima foi um discípulo dedicado e talentoso, da terceira geração de Lucio Costa e Oscar Niemeyer.

Lima é um arquiteto conhecido no Brasil pelo uso da argamassa-armada nas obras pré-fabricadas e pelo desenvolvimento de arquitetura de hospitais para o aparelho locomotor da Rede Sarah Kubitschek. Ao longo de sua vida recebeu várias premiações, em 1998 recebeu o prêmio da Bienal Ibero-Americana de Arquitetura e Urbanismo (Madri), em 2000 expôs na Sala Especial na Bienal de Veneza e recebeu reconhecimento com o Grande Prêmio Latino-Americano de Arquitetura da 9a Bienal Internacional de Arquitetura de Buenos Aires, em 20017.

O arquiteto Lima iniciou sua carreira com o trabalho de desenhista no Instituto de Aposentadorias e Pensões dos Bancários (IAPB) e após a conclusão no curso de arquitetura, ainda jovem e recém-formado, com 25 anos, foi para Brasília integrando a comissão de construção dos Institutos de Aposentadoria, coordenado pelo arquiteto Oscar Niemeyer (n.1907), autor dos projetos de arquitetura dos edifícios.

A parceria com Niemeyer seria definitiva e marcaria toda sua carreira, inicialmente na integração da equipe de execução das superquadras, e posteriormente, nos trabalhos da Universidade de Brasília, na reflexão conjunta sobre a

4 Lelé era jogador do Vasco e jogava na meia direita, mesma posição de João Filgueiras Lima quando adolescente, por isso apelido recebido e que persiste até os dias de hoje.

5 Toca piano, teclado e acordeão.

6 Universidade Federal do Rio de Janeiro.

7 Disponível em: <http://www.itaucultural.org.br/aplicexternas/enciclopedia_ic/index.cfm?fuseaction $=$ artistas_biografia\&cd_verbete=6245\&cd_item $=1 \& c d \_i d i o m a=28555>$. Acesso em 13 out 2010 . 


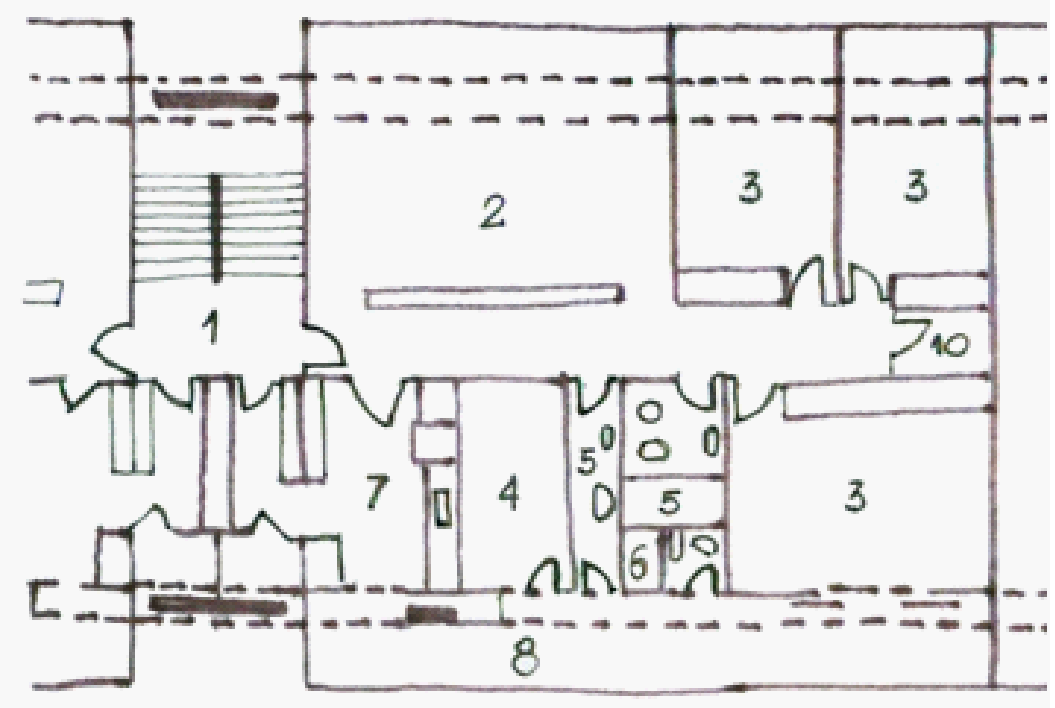

Figura 99: Planta Alojamento de professores UnB, 1. Circulação, 2. Estar, 3. Quartos, 4. Q. Empregada, 5. Banheiro, 6. Banheiro empregada, 7. Cozinha, 8. Área Serviço, 9. Despensa, 10. Depósito. Fonte: (LATORRACA, 2000, p. 36). 


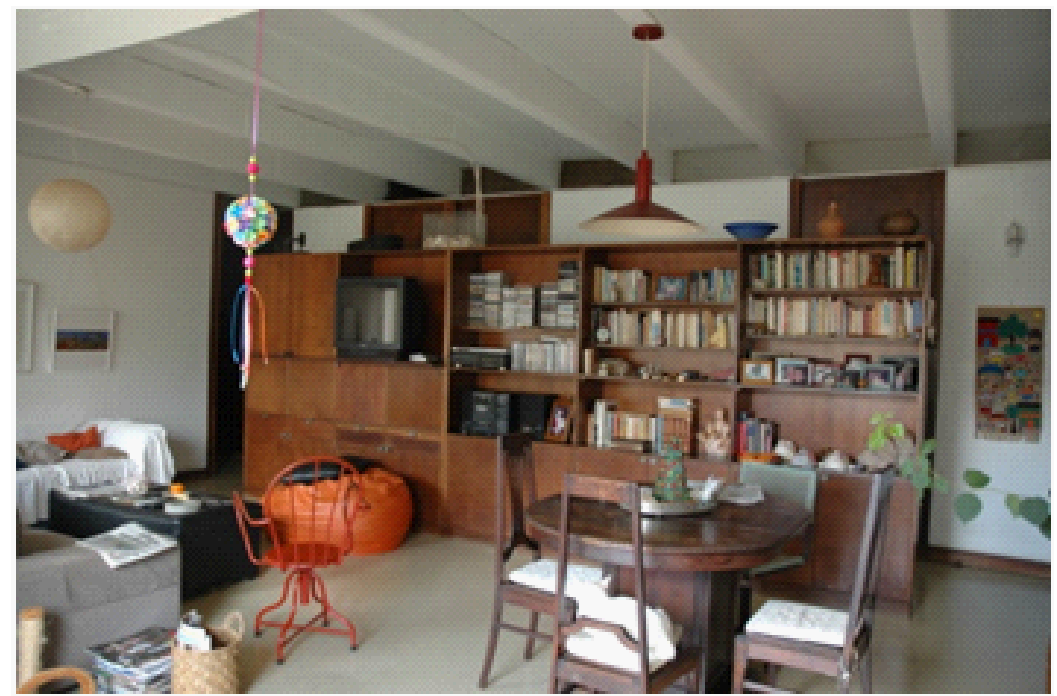

Figura 100: Sala Estar com armário divisor de ambientes. Alojamento de professores. Foto: Acervo Pessoal. Foto tirada em 30/12/2010. 
responsabilidade social do arquiteto, na aprendizagem sobre industrialização e no desenvolvimento de projetos hospitalares.

Lima teve como principais influências o arquiteto Oscar Niemeyer ${ }^{8}$ e o contexto da criação da Universidade de Brasília em 1960. E em entrevista dada a Cynara Menezes (2004) indicou que os arquitetos Alvar Aalto (1898-1976) e Arne J acobsen (1902-1971) como profissionais que ele considerava referências.

Esses profissionais tiveram grande influência na formação do jovem arquiteto. Em sua postura profissional ética, no entendimento da sociedade da época, e do processo arquitetônico que envolvia o projeto e a produção.

Dentre as influências de Niemeyer sobre J oão Filgueiras Lima, pode-se destacar que a experiência de Lima em Brasília Ihe trouxe a prática em projeto e execução, como ele mesmo conta, “[...] E eu tive que resolver todos os detalhes da execução da obra: caixilharia, detalhes de fôrmas [...]" (LIMA apud LATORRACA, 2000, p. 17).

Dessa forma pode-se dizer que Lima foi um construtor. Em suas palestras ele sempre mostrava o comportamento de cada tipo de estrutura e como as forças agem sobre a mesma, através de suas diversas obras e experimentos, atitude típica de um profissional que esteve ligado ao canteiro de obras e teve uma formação de engenheiro-arquiteto.

Uma de suas primeiras experiências com pré-fabricados foi no alojamento para professores da UnB, como mostram as figuras ao lado, que ele definiu como:

[...] construções simples e econômicas. A estrutura pré-fabricada utiliza dentro das possibilidades da maquinaria, grandes elementos pré-moldados. Assim, colunas, vigas, lajes e os próprios caixilhos das esquadrias são de concreto armado, o que permite construção rápida e

8 Formou-se pela Escola de Belas Artes do Rio de Janeiro em 1934, foi estagiário de Lucio Costa e fez parte da equipe que projetou e construiu o Ministério da Educação e Saúde sob consultoria de Le Corbusier. Segawa (2002, p.96) descreve que o reconhecimento de Niemeyer se deu com a "consagração da Feira Mundial de Nova York" em 1939. 
os preços desejados (LIMA, 1963, p. 39).

O edifício de apartamentos foi elaborado basicamente com três partes: as vigas, as lajes pré-moldadas e a caixa de escadas construída no local. O apartamento é setorizado em área íntima, serviço e estar. Os banheiros são racionalmente agrupados, a área de serviço é vedada com elemento vazado e a viga interna é exposta por todo percurso da unidade. A lógica de produção em série, recorrente na época, foi marcada no processo produtivo do arquiteto, que será apresentado posteriomente.

Outra referência importante para Lima foi Hugo Alvar Henrik Aalto ${ }^{9}$ (1898-1976). Um dos aspectos fundamentais para Alvar Aalto era a consideração que tinha pelo ser humano. $O$ respeito era expresso através da inserção de detalhes minuciosos colocados em seus projetos, tais como a luz ao lado da cama, o ar fresco sem causar correntes de ar, o fluxo de água com pouco ruído nas pias, e o sistema de calefação colocado no teto (GIEDION, 2004, p. 656).

Aalto descrevia a arquitetura mais humana como:

[...] uma arquitetura melhor, e isso significa um funcionalismo muito maior do que o meramente técnico. Este objetivo só pode ser realizado por métodos arquitetônicos - pela criação e combinação de coisas técnicas diferentes, de tal maneira que irá proporcionar para o ser humano a vida mais harmoniosa. [... $]^{10}$ (AALTO, 1970. p. 16, tradução nossa).

O humanismo defendido por Aalto, assim como o preconizado por Lima era aquele que compreendia a arquitetura como um instrumento para proporcionar ao ser

9 Nascido em Kuortane - Finlândia, graduou-se pela Technical University Helsinki (1921). Teve escritório em Jyaäskylä (1923-1927), Turku (1927-1933) e Helsinki (1933). Em 1938 foi para os Estados Unidos e em 1940 foi convidado para lecionar no College of Architecture of the M.I.T.

10 Original em inglês: To make architecture more human means better architecture, and it means a functionalism much larger than the merely technical one. This goal can be accomplished only by architectural methods - by the creation and combination of different technical things in such a way that they will provide for the human being the most harmonious life [...] (AALTO, 1970. p. 16). 

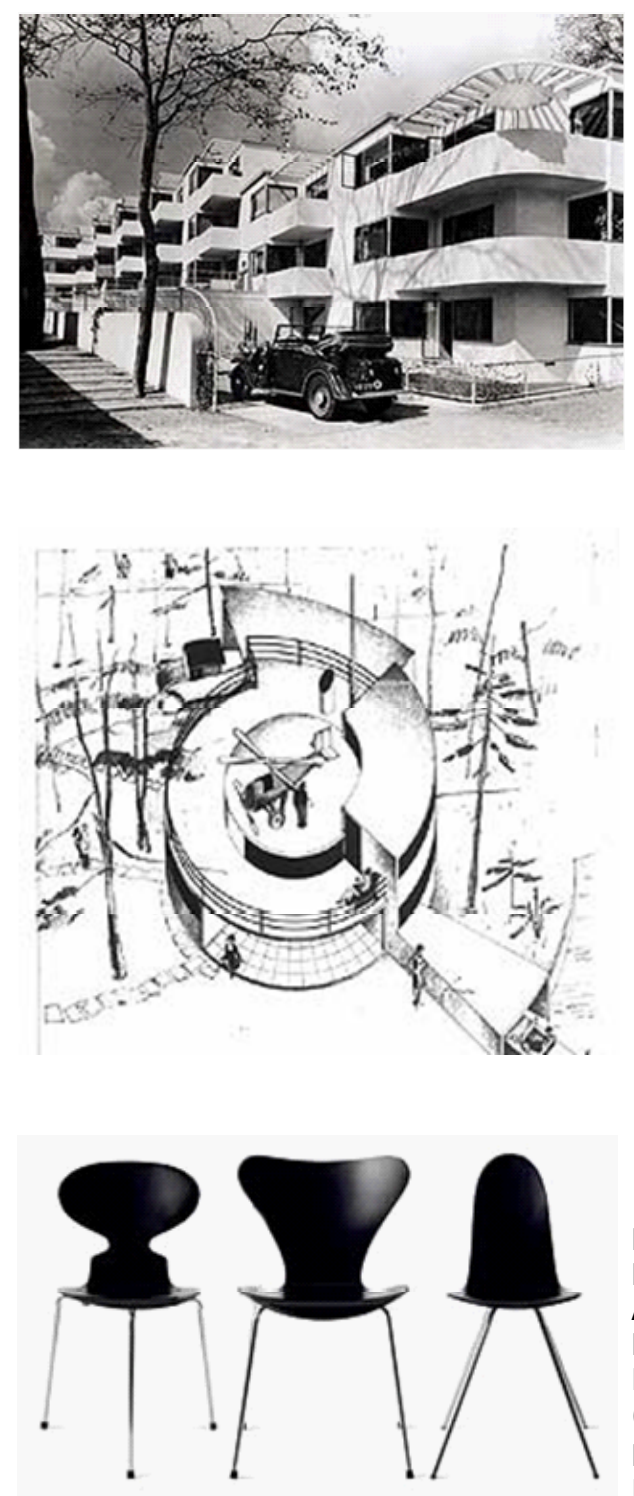

Figura 101: Bellavista,

Klampenborg (1931-1934). Fonte: Arne J acobsen.

Figura 102: Desenho cortesia KAB Desenho para a Casa do Futuro (1929). Fonte: Arne J acobsen. Figura 103: "The Ant" and "The Number Seven". Fonte: Arne J acobsen. 
humano uma qualidade de vida melhor. Aalto, certamente era um profissional à frente de seu tempo, pois se preocupava com o homem, seu estado mental e físico. Ele acreditava que a iluminação, ventilação, conforto térmico e acústico poderiam viabilizar a cura e o bem-estar.

O aspecto de adequação, adaptação e crescimento dos edifícios também foi verificado na arquitetura de Lima, que considerava sua produção um objeto adaptável graças aos elementos modulados e industrializados, tais como os painéis modulados, pilares e vigas. Seus pontos de vista eram exemplificados nos seus cursos e palestras através da figura de uma árvore que possuía um caule ou eixo central, que se ramificava em sua copa e raiz, e podia crescer e se adaptar indefinidamente.

Há similaridades entre as posturas de Alvar Aalto e J oão Filgueiras Lima. Ambos utilizaram a tecnologia e a arquitetura para proporcionar conforto e bem-estar aos ocupantes de suas edificações. como por exemplo, os sistemas de refrigeração de $\operatorname{ar}^{11}$, a circulação de ar por pressão negativa ${ }^{12}$, o aproveitamento da iluminação natural e os painéis sanduíches ${ }^{13}$, dentre várias outras técnicas que controlavam a temperatura intema dos ambientes, além da visão do objeto arquitetônico que poderia crescer e adaptar-se conforme as necessidades de cada um.

\section{Outra referência comentada por Lima foi o arquiteto e designerArne J acobsen ${ }^{14}$}

\footnotetext{
11 Lelé utilizou em vários de seus projetos, correntes de ar que passam por aspersão de água e que posteriormente entrarão no edifício. Esse artifício chega a diminuir em torno de 3 graus de temperatura do ar.

12 Efeito físico criado pelo vento que passa sobre os sheds e provoca a sucção do ar que está no interior do edifício.

13 Os painéis de argamassa-armada fabricados na fábrica têm $2 \mathrm{~cm}$ de espessura, eram montados paralelamente e entre os painéis era colocada uma placa de isopor que não deixava os painéis não encostarem um nos outros para evitar o aquecimento por contato.

14 Dinamarquês, estudou no Royal Danish Academy of Fine Arts, School of Architecture em Copenhagen. Foi autor das cadeiras The $A n t^{T M}(1952)$, Series $7^{T M}(1955)$, The Egg ${ }^{T M}$ e The Swan ${ }^{T M}$ (1958). Como arquiteto, seus principais trabalhos foram os Blocos de apartamentos no bairro Bellavista - Klampenborg, Dinamarca (1933-34), SAS Royal Hotel Copenhagen, Dinamarca (1958- 1960) e, Saint Catherine's Col/ege em Oxford, Inglaterra (1964- 66).
} 
(1902-1971). J acobsen foi reconhecido pela interpretação do funcionalismo internacional (SCANDINAVIANDESIGN, 2010). trabalhou como arquiteto, com edificações, interiores, mobiliários, área têxtil e cerâmica. A "Ant"foi a primeira cadeira a se tornar mundialmente reconhecida de uma série de cadeiras leves com assento e encosto em madeira moldada. A cadeira "seven"tornou-se a mais importante na história da mobília dinamarquesa pelo seu sucesso em vendas. Foram fabricadas mais de 5 milhões de cópias.

O Hotel Royal (1956-61) de Copenhagen foi uma das obras mais conhecidas de Arne J acobsen. Nesse projeto ele desenhou várias peças de mobiliário, luminárias, tecidos, copos e maçanetas. J acobsen trabalhava em todas as escalas de projeto, desde a edificação até os talheres ${ }^{15}$ (SCANDINAVIANDESIGN, 2010).

A semelhança entre J acobsen e J oão Filgueiras Lima mostra que ambos são profissionais que trabalhavam em diferentes escalas, desde o edifício até o mobiliário. E certamente, os dois parecem ser determinados na perfeição do detalhamento de seus projetos. Como mostra a cama-maca de Lima na figura. a seguir. 


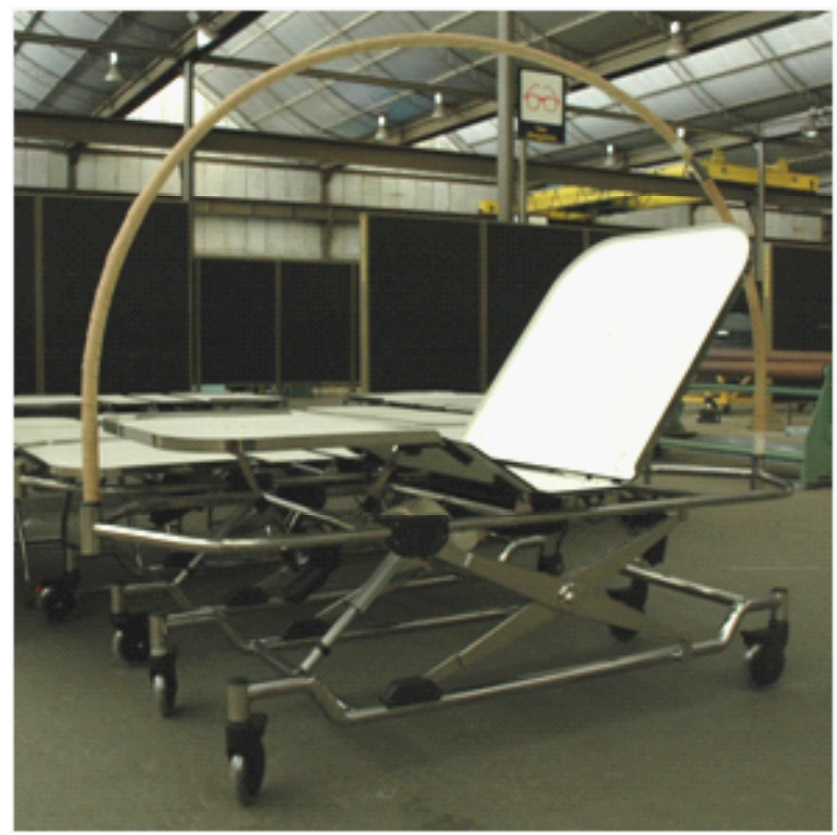

Figura 104: Cama-maca automatizada desenvolvida por J oão Filgueiras Lima - CTRS

(07/2010). Fonte: acervo pessoal. 


\subsection{A Teoria Geral de Sistemas (TGS)}

A Teoria Geral de Sistemas parece ter subsidiado praticamente todas as técnicas desenvolvidas na industrialização e nas produções de J oão Filgueiras Lima. A discussões acerca da teoria datam da década de 1920, mas a publicação do livro que trata da teoria pelo principal incentivador Lwdwig von Bertalanffy sobre a teoria só foi realizada em 1968 (BERTALANFFY, 1975, p. 28).

A TGS retratava a relação entre as partes e o todo e era aplicado na lógica de industrialização de produtos e na produção da arquitetura através da organização em partes e no entendimento da cidade como subsistemas funcionais de circulação, moradia, comércio, etc.

Os sistemas foram definidos por Bertalanffy como "um complexo de elementos em interação" (BERTALANFFY, 1975, p. 84) e a atenção era centrada no organismo como totalidade (BERTALANFFY, 1975, P. 256). O Bertalanffy Center for the Study of Systems Science (2010) compreende que os elementos ou partes do sistema eram dinâmicos, estavam em interação mútua, e podiam ser considerados outros subsistemas.

A teoria tinha como objetivo:

[...] formulação de princípios válidos para os "sistemas" em geral, qualquer que seja a natureza dos elementos que os compõe e as relações ou "forças" existentes entre eles. (BERTALANFFY, 1975, p. 61)

Segundo Elohimjl (2010) as teorias que utilizavam o conceito de sistemas seguiam basicamente duas abordagens; a analítica que tentava identificar inicialmente os elementos que constituíam o sistema e a abordagem holística, que reconhecia o sistema como uma totalidade e posteriormente seus elementos.

Elohimjl (2010) também considerava que a Teoria de Sistemas de Bertalanffy era uma forma de lidar com diversas variáveis relacionadas a múltiplos fatores 


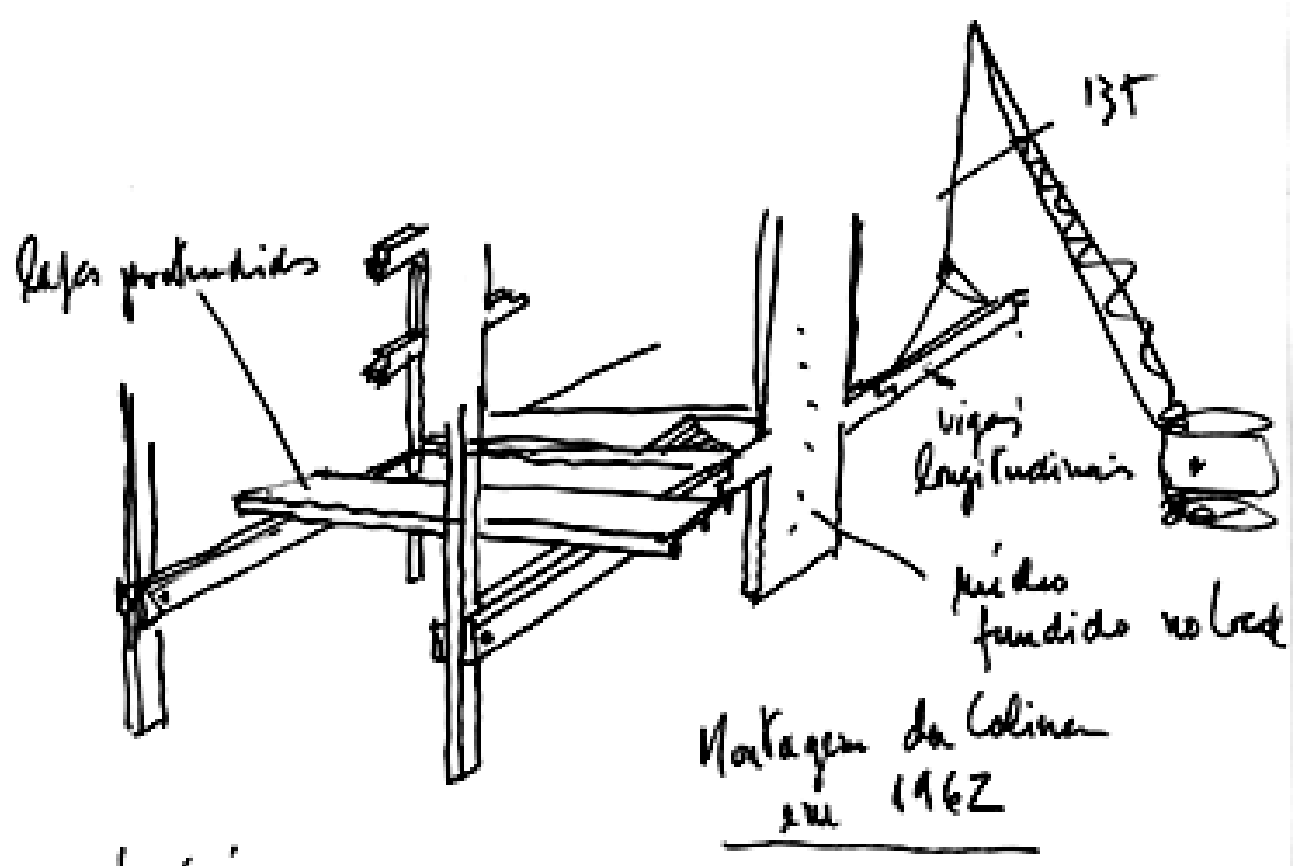

Wi' 14/07/2010

Figura 105: Croqui de montagem

dos alojamentos de professores

da UnB - Lajes protendidas, vigas

local. Desenho J oão Filgueiras

Lima (2010). Fonte: acervo pessoal.

220 
envolvidos, um quadro teórico para organizar uma pesquisa e restabelecer o equilíbrio em sistemas alterados. François (1998) afirmava que a Teoria Geral de Sistemas era como um "conjunto de conceitos e modelos que poderiam ser usados para compreender as relações" 16 e Beer (1974) a definia como uma "ciência geral de organização e da integridade ${ }^{\prime 17}$ (BEER, 1974) e Schoech (2004) afirmava que o pensamento sistêmico "é uma abordagem teórica para compreensão dos fenômenos"18 (SCHOECH, 2004).

De modo geral, Bertalanffy estava preocupado com a compreensão dos sistemas, tendo como base o entendimento e a evolução dos seres vivos. Seu foco estava centrado principalmente na modificação dos comportamentos do organismo, pois acreditava que os homens tinham capacidades iguais e poderiam, portanto ser, condicionados a determinadas ações e condutas.

Nos trabalhos de Lima, a Teoria Geral de Sistemas pode ser analisada através dos alojamentos da Colina. Lima utilizou o concreto pré-fabricado, havia um núcleo central moldado em loco. Como mostra a figura ao lado:

A relação entre as partes que formavam o todo era fundamental no sistema da construção industrializada. Cada peça ou elemento que constituía o edifício necessitava de uma integração total dos desenhos.

É possível encontrar similaridades entre a ideia de ciclo aberto e fechado com a Teoria Geral de Sistemas. Na teoria,

O organismo não é um sistema fechado, mas aberto. Dizemos que um sistema é "fechado" se nenhum material entre nele ou sai dele. É chamado "aberto" se há importação e exportação da matéria (BERTALANFFY, 1975, p. 167).

16 Original em inglês: $A$ set of concepts and models which can be used to understand relationships and moreover, simultaneous, transient and shifting relationships (FRANCOIS,1998).

17 Original em inglês: [...] a general science of organization and wholeness (BEER, 1974).

18 Original em inglês: Systems'thinking is a theoretical approach to understanding phenomena. Disponivel em: <http://www2.uta.edu/cussn/courses/ 3306/coursepack/theory_systems.pdf>. Acesso em: 30 out 09. 
Nessa condição em que o organismo foi analisado, pode-se fazer um paralelo com a edificação construída industrialmente. $O$ edifício poderia ser o organismo construído com materiais do mercado (ciclo aberto) ou a partir de uma única fábrica (ciclo fechado). Verificou-se, assim, a íntima relação entre a Teoria Geral de Sistemas e a proposta de pré-fabricação de J oão Filgueiras Lima no que se refere à elaboração do projeto, do desenho em partes e no todo, de produção dos elementos ou componentes em fábrica e montagem em canteiro.

A elaboração dos elementos executados em fábrica foi a própria materialização da Teoria Geral de Sistemas, que decompôs o edifício em inúmeras partes para trabalhar em cada uma delas e posteriormente agregá-las e constituir o "organismo", como denominava Bertalanffy. Além da relação formal do desenho em nível do objeto, havia a dissecação do componente no aspecto funcional e técnico, traduzidos nos diferentes setores de argamassa-armada, siderurgia e marcenaria, a relação do desenho de cada peça, o encaixe perfeito entre elas e a montagem final em canteiro de obras.

Como se pode obsenvar a Teoria Geral de Sistemas se ajustou perfeitamente à produção da construção fabril e à arquitetura que tinham como objeto um edifício visto como o organismo formado por subsistemas, e que formava um todo.

\subsection{Conceito de Habitat}

O conceito de habitat como espaço para o homem viver, também parece presente no trabalho de Lima, dado o nome de seu escritório atual, Instituto Brasileiro da Tecnologia do Habitat.

Ao perguntar ao arquiteto o motivo da escolha desse nome, ele respondeu:

[...] O que estamos pretendendo é justamente o que esse nome exprime melhor. A proposta é integrar todas as necessidades do ser 
humano para o seu habitat, ou seja, a parte de urbanização, na parte primordial de moradia, em todos os complementos sociais que a estrutura exige, enfim, a intenção de nosso instituto é integrar todos os conhecimentos que têm que interferir na construção do habitat do ser humano ${ }^{19}$ (LIMA, 2010).

A partir desse depoimento, pode-se verificar que $o$ arquiteto entendia 0 habitat como o ambiente composto pelos: ambiente urbano, de moradia e os equipamentos sociais; espaços necessários para o ser humano. E o papel do arquiteto enquanto técnico era fazer a integração dessas necessidades.

Esse entendimento do arquiteto sobre o habitat sugere uma visão sistêmica do ambiente, a TGS analisou igualmente o meio ambiente formado por outros subsistemas.

Assim, pode-se afirmar que Lima pensa no habitat como um todo, e o papel do profissional seria integrar os conhecimentos que eram segmentados:

A intenção é ser uma coisa ampla que reflete no habitat do ser humano como um todo e a ideia é integrar, pois eu acho que a nossa profissão, o que está ocorrendo, no mundo inteiro, é uma fragmentação total do conhecimento, não há uma integração entre os múltiplos saberes que exigem uma profissão. (LIMA, 2010)

De acordo com a visão de Lima, o ser humano deveria ser observado de forma integral, postura que também poderia ser aproximada ao olhar sistêmico de compreender o mundo, e ele seria, então considerado um ser total e indivisível. De acordo com Mulerj (2004), estudioso da Teoria Geral de Sistemas, uma das ideias essenciais de Bertalanffy era a visão holística se contrapondo à visão da ciência positivista e da especialização.

Nesse aspecto Lima incorporou, mesmo que tenha sido através da prática profissional, o ponto de vista decorrente dessa orientação, em que as diversas

19 Entrevista realizada com o arquiteto em 14 jul 2010, em Salvador - Ba. 
partes tinham que ser integradas tanto ao conhecimento para a construção do objeto arquitetônico como aos conhecimentos e necessidades do próprio ser humano. Essa integração deveria ser feita com a união dos diversos profissionais, os conhecimentos e as necessidades do ser humano.

\subsection{A Consciência Social e Coletiva como princípio norteador}

Lima também apresenta uma consciência social e coletiva em sua produção, mas que possivelmente é resultado de um pensamento vigente nos anos 1960.

Conforme Marcelo Ridenti, autor de Em busca do povo Brasileiro - artistas da revolução, do CPC a era da TV, nos anos 1950, 1960 e início de 1970, os intelectuais brasileiros estavam comprometidos com a realidade social, queriam acabar com o subdesenvolvimento e criar uma sociedade mais justa e com uma identidade brasileira.

Os intelectuais tinham representação na esfera pública, na imprensa, nas artes e nos palcos, eram ativos em vários ramos da sociedade, independentemente de estarem vinculados a um espaço institucional. Ridenti ainda completa em uma entrevista dada ao J ornal da Unicamp:

Na década de 1960 estavam em luta pelo menos dois projetos para o desenvolvimento do capitalismo no Brasil. Um que foi derrotado em 1964, que era o projeto de construir um capitalismo de massas, como pregava o economista Celso Furtado. Ou seja, utilizar os investimentos do Estado para o desenvolvimento do país e promover um mercado popular, de produtos acessíveis para a maioria da população, com uma relativa distribuição de riqueza. [...] Um outro projeto que foi na direção do que tem sido o desenvolvimento do capitalismo em escala internacional. Esse projeto criou um fosso entre uma minoria ínfima de proprietários do capital e a maioria da população [...] (RIDENTI, 2002, p. 7) 
Esse aspecto social estaria presente também em sua arquitetura, pensada com materiais simples e necessários ao uso de cada função, como o uso da argamassaarmada que não necessita de acabamentos ou manutenção ao longo de sua vida útil.

Sales (2000), um estudioso dos processos históricos que envolvem o Partido Comunista explica que as propostas do PCdoB eram de caráter "democrático burguês" (SALES, 2000, p. 134), que a princípio incentivariam o desenvolvimento capitalista do país, e para isso era necessário libertar o país da espoliação dos capitais norte-americanos, da mentalidade feudal e do latifúndio através de uma reforma agrária. O segundo passo seria a aplicação dos investimentos em obras sociais para diminuir as diferenças existentes e o terceiro passo seriam os meios utilizados para a efetivação da revolução.

$\mathrm{Na}$ entrevista realizada com Lima, ele descreve o pensamento da época:

$\mathrm{Na}$ época da universidade de Brasília, evidentemente que eu era comunista, todos éramos comunistas, havia uma posição política muito exacerbada de esquerda no grupo todo, havia uma compromisso ideológico muito grande com todas as pessoas que se envolveram nesse trabalho, era um compromisso social, o que nós queríamos realmente era mudar o mundo levando em conta uma sociedade mais justa, mais equilibrada em relação a pobreza. Era um trabalho que correspondesse à revolução social de nosso país através do ensino, da construção, fazer uma fábrica para construção ${ }^{20}$ (Lima, 2010).

Após a inauguração de Brasília, frente às transformações econômicas, sociais e políticas se instalou a ditadura militar em 1964 e interrompeu o processo democrático (RIDENTI, 2010, p. 3). Essa cisão representaria o sufocamento das propostas socialistas e do sonho por uma sociedade mais justa, marcada por uma sequência de repressão social e política que duraria até a anistia em 1979.

No Brasil, pode-se datar os anos rebeldes do fim do governo

20 Entrevista concedida a autora em 14 jul 2010. 
Kubitschek - simbolizado pela inauguração de Brasília como nova capital federal, em 1960, expressado a rápida modernização do país nos anos anteriores - até a promulgação do Ato Institucional no. 5, de dezembro de 1968, que acabou com o florescimento político e cultural e deixou claro que estava no poder uma ditadura militar e civil que não teria clemência com seus inimigos. [...] (RIDENTI, 2010.p.2)

A formação de Lima foi marcada pela forte intenção de justiça e igualdade social verificada no grupo de trabalho dos profissionais que estavam ao seu redor, como Darcy Ribeiro, Oscar Niemeyer, entre outros. A questão do Bem Estar também foi uma situação do período analisado no trabalho.

Como comenta Sevcenko (2001) após a Segunda Grande Guerra Mundial, instalouse a Guerra Fria, caracterizada pela dominação mundial dividida entre Estados Unidos e União das Repúblicas Socialistas Soviéticas. Nesse período, os países desenvolvidos buscavam diferentes formas de domínio armamentista, e nos países do terceiro mundo, eram comuns os governos ditadores e os golpes militares.

De acordo com Harvey (1989), em decorrência dos graves problemas decorrentes da Segunda Guerra Mundial, no cenário da dominação das duas grandes potências, houve a necessidade de se elaborar programas que garantissem maior segurança e melhor qualidade de vida, habitação digna, previdência social, bem estar e criação de oportunidades através da criação de empregos para um futuro melhor, com o objetivo de garantir a paz e a prosperidade internacionais.

[...] Sob o olho vigilante e às vezes a mão forte do Estado, foram tomadas medidas para eliminar habitações miseráveis e construir casas, escolas, hospitais, fábricas etc. modulares através da adoção dos procedimentos de planejamento racional e dos sistemas de construção industrializada que os arquitetos modernistas há muito tinham proposto. E tudo isso integrado por uma profunda preocupação, expressa repetidas vezes nas leis, com a racionalização dos padrões espaciais e dos sistemas de circulação para promover a igualdade (ao menos de oportunidade), o bem-estar e o crescimento econômico 
(HARVEY, 1989, p. 71).

Sob o incentivo do Estado de Bem Estar Social, a criação da Universidade de Brasília foi um importante marco para a história intelectual brasileira. Concebida por Anísio Teixeira e Darcy Ribeiro no governo de J uscelino Kubitschek em 1960, tinha o ideal de construir uma universidade modelo.

Anísio Teixeira foi um dos principais educadores da história brasileira, preconizava a escola gratuita, associada a prática e para todos, na sua concepção,

[...] Anísio Teixeira vê a necessidade de uma teoria educacional indissociável de um saber prático. Anísio passa a assumir uma posição filosófica firmada no exemplo de John Dewey. Dewey foi um progressista social. Concebia a educação como um processo de recriação ou reconstrução do educando por meio da experimentação. Propunha a educação em e para o educando, sendo Anísio um dos precursores desta visão no meio educacional brasileiro (PORTO, 2001, p. 127).

De acordo com Darcy Ribeiro,

[...] fôra os progressos da técnica e da ciência que possibilitaram a renovação e inovação das atividades produtivas, daí resultando o desenvolvimento desses países. O progresso social se faz portanto, mediante um processo de interação constante entre o saber e a técnica (RIBEIRO, 1963, p. 2).

A escola teria papel socializador e segundo Anísio Teixeira, a educação deveria ser capaz de restaurar e romper com as diferenças da sociedade. Teixeira entendia a educação como um direito, não como um privilégio; como geral e humanista; como base da democracia e com capacitações constantes para os docentes (PORTO, 2001).

A Universidade proporcionaria o assessoramento público com características de alta qualificação científica, liberdade e autonomia dos docentes. Teixeira e Ribeiro 
acreditavam que o corpo intelectual não deveria ter nenhum tipo de amarras ou subordinação, pois seria a consciência crítica da nação. Como o próprio Darcy Ribeiro descreveu:

O grande desafio que se apresenta à nossa geração - o de tornar próspera uma nação de 70 milhões de habitantes, detentora de um dos maiores patrimônios mundiais de recursos naturais - é o pleno domínio e aplicação do saber e da técnica modernas mediante a criação de um sistema escolar capaz de preparar prontamente um grande contingente de trabalhadores altamente qualificados (RIBEIRO, 1963, p. 3).

A UnB tinha como conceito básico a integração entre a técnica e a ciência, e utilizava como instrumento de ensino a formação prática aliada à teórica, no intuito de formar um profissional qualificado. Como descreve o professor Darcy Ribeiro.

O projeto de lei que instituiu a Universidade de Brasília foi elaborado visando, como objetivo mais alto, conduzir as universidades brasileiras, mediante a implantação de um modelo novo de organização universitária, à adoção das reformas estruturais reclamadas há anos, com o propósito de adaptá-las às necessidades de formação de cientistas e tecnólogos para atender aos imperativos do desenvolvimento nacional (RIBEIRO, 1963, p. 4).

A criação da Universidade de Brasília nos anos 1960 se insere em um contexto maior de valorização da educação, segundo Hobsbawn (1995), também nos países da América Latina, houve

[...] o crescimento de ocupações que exigiam educação secundária e superior. A educação primária universal, isto é, a alfabetização básica, era na verdade a aspiração de todos os governos, tanto assim que no fim da década de 1980 só os Estados mais honestos e desvalidos admitiam ter até metade de sua população analfabeta. (HOBSBAWM, 1995, p. 289)

Segundo Guimarães (2003), Oscar Niemeyer fazia parte da comissão de estudos complementares e também era responsável pela coordenação do Instituto de 
Arquitetura da UnB. O Ceplan era um órgão que tinha como objetivo projetar os edifícios de Brasília de acordo com as normas estabelecidas para o plano piloto, orientar e conduzir os cursos da Faculdade de Arquitetura.

O Ceplan era um laboratório que unia a prática executiva e os conceitos projetuais, um local em que deveriam ser experimentadas novas tecnologias e propostas para aplicação na cidade de Brasília e na própria UnB. Os alunos teriam a oportunidade de discutir e vivenciar o desenvolvimento dos projetos construtivos bem como a sua execução na prática. Essa atitude seria uma maneira de unir a teoria e a prática na formação dos novos profissionais.

A convite de Darcy Ribeiro e Oscar Niemeyer, J oão Filgueiras Lima assumiu a função de secretário executivo do Ceplan em 1961. Ele era responsável pelo curso de pós-graduação em arquitetura e pelo curso de técnica e tecnologia da construção. O Centro tinha na época a intenção de ser um grande núcleo de construção industrializada (LIMA, 2004, p. 51). Segundo Alberto (2009), Oscar Niemeyer e sua equipe desenvolveram projetos de pré-fabricação para vários edifícios, e o próprio prédio da Ceplan foi construído a partir de dois elementos estruturais, painéis de vedação e vigas protendidas.

Nesse período Lima, a serviço da UnB, foi para o Leste Europeu ${ }^{21}$ durante 3 meses para estudar os sistemas construtivos pré-fabricados e montar uma fábrica de construção na universidade. A atividade profissional de J oão Filgueiras Lima, aliada ao seu profundo conhecimento sobre o comportamento das estruturas, foram desde o princípio direcionados para a construção industrializada, incentivada por Oscar Niemeyer. De acordo com Guimarães:

A partir da criação desse órgão foi possível introduzir um novo ritmo de trabalho em Brasília, [...] visando construções rápidas e econômicas. Deflagra-se uma fase específica da arquitetura brasileira voltada às pesquisas de processos construtivos industrializados, à realização de

21 Lelé esteve na Rússia, Alemanha, Polonia e Techoslováquia. 


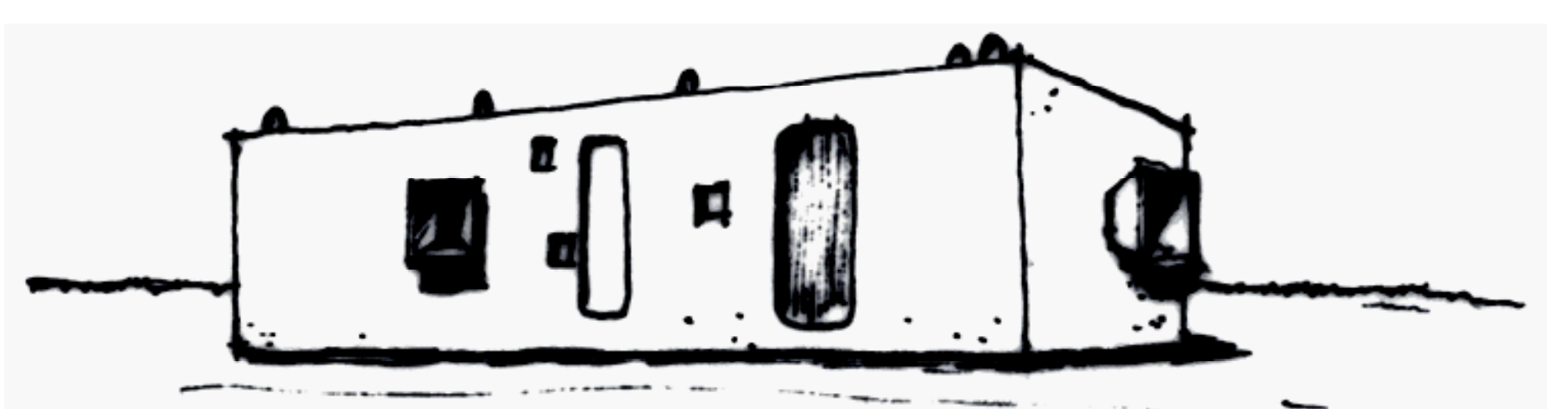


um tipo novo de edificação cuja virtude fosse representada também pelo seu caráter funcional e por uma linguagem estética que revelasse simplicidade (GUI MARÃES, 2003, p. 24).

Como exemplo desse período, Niemeyer desenvolveu Módulos de habitação para utilizar nas cidades da periferia de Brasília, chamadas cidades satélites. As unidades seriam fabricadas industrialmente em concreto pré-moldado, e poderiam ser colocadas em terreno nivelado formando um agrupamento horizontalizado ou verticalizado até quatro andares. A montagem e o transporte seriam realizados por guindastes e carretas, e organizados uns sobre os outros, como unidades individuais ou coletivas. Os usuários poderiam adquirir a unidade básica e posteriormente os mobiliários e os elementos internos para as subdivisões dos espaços. Como mostram as figuras ao lado.

A participação de J oão Filgueiras Lima no início da UnB foi determinante em seu aprimoramento intelectual e na compreensão de sua responsabilidade social como profissional arquiteto. Haja vista que a prática de formação de mão-de-obra e o entendimento entre prática e teoria estariam presentes nas fábricas que ele iria coordenar. Lima aprofundou seus conhecimentos sobre o processo construtivo industrializado em países socialistas, fato que motivou ainda mais a sua postura de proporcionar uma sociedade mais justa e igualitária.

A racionalização da construção através da industrialização e consequente diminuição dos custos era ferramenta para proporcionar a construção do habitat formado pelo complexo edificado, necessário para o desenvolvimento do ser humano. A professora Otilia Arantes comenta sobre a década de 1960 no livro Urbanismo em fim de linha, publicado em 1998:

O que é preciso ter em mente é que essa arquitetura por mais extraordinária que possa ter sido, trazia uma ambiguidade básica de nascença, ela não estava apenas rompendo com o mundo a volta, ela ajudou a Ihe dar forma - ela não foi portanto apenas crítica, mas 

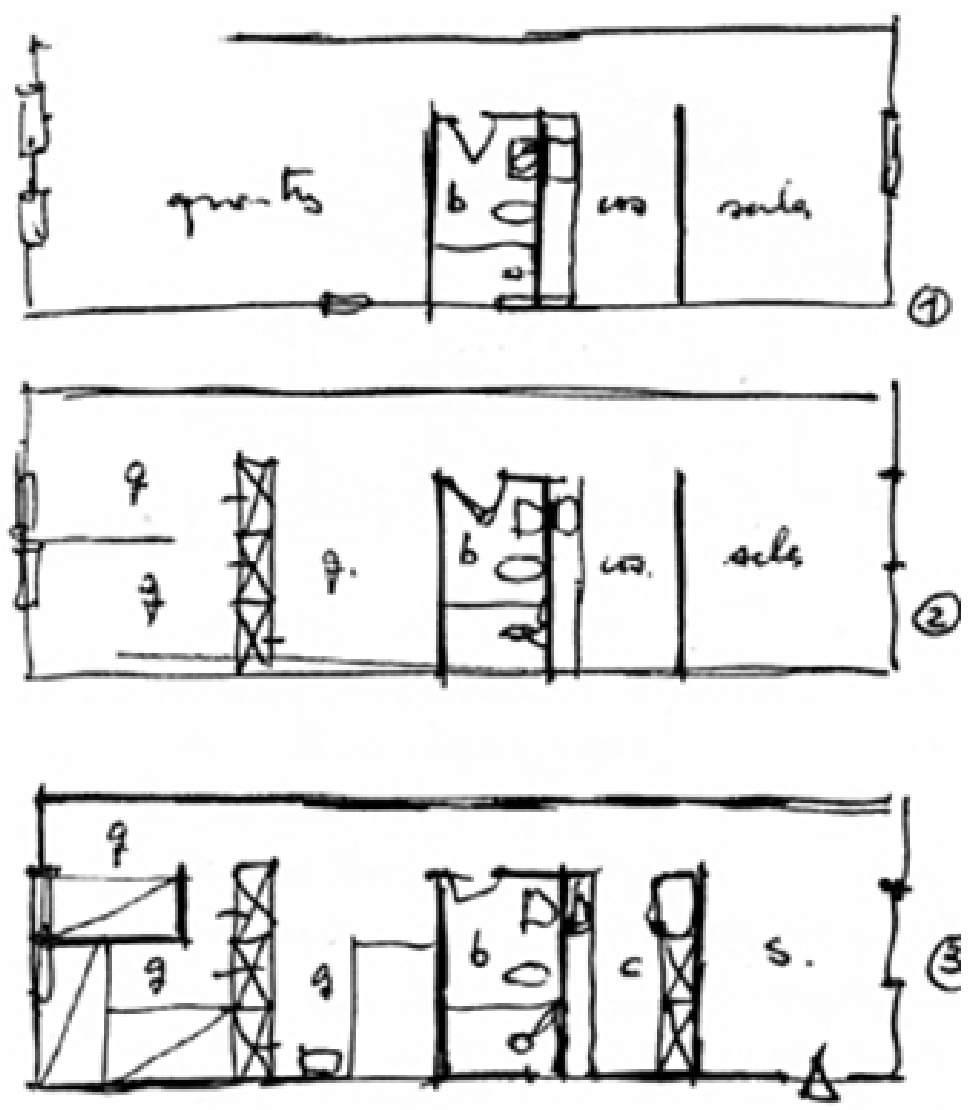

Figura 107: Etapas de aquisição da unidade de habitação industrializada (45 m2 - 42 ton.). Fonte: Rev. Módulo no. 27,1962 , p. 32 - croqui de Oscar Niemeyer. 


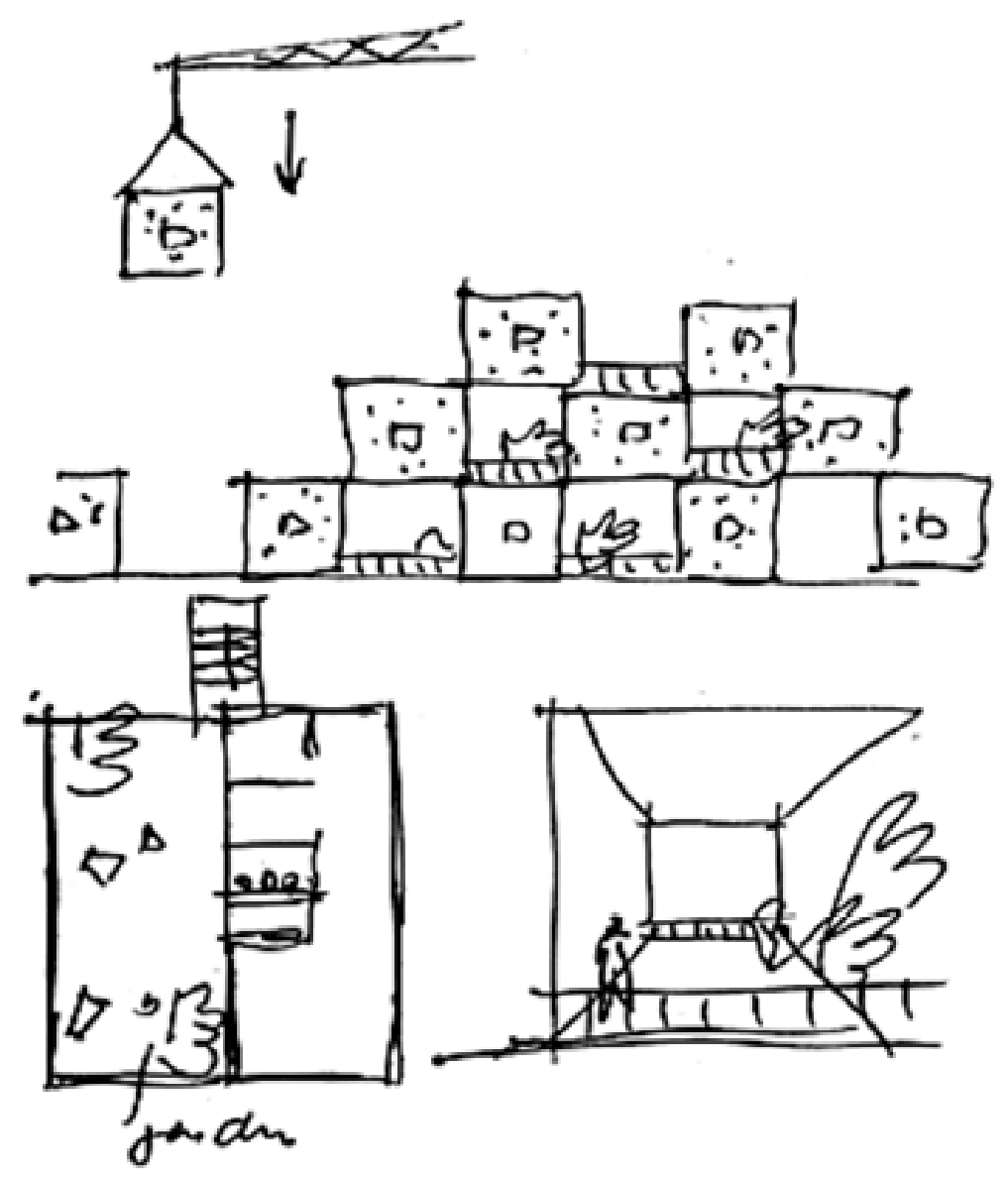

Figura 108: Organização verticalizada das unidades de habitação com jardim entre as habitações. Fonte: Rev. Módulo no. 27, 1962, p. 34 croqui de Oscar N iemeyer. 
também integradora [...] O discurso da funcionalidade social alardeado estava inchado de ideologia: ajustadas aos princípios da linha de montagem, como células que vão se ordenando no tecido urbano, as edificações obedecem antes ao consumo de massa, ou seja, à lógica da produção em série, do que às necessidades reais dos indivíduos a que se destinam. Trata-se assim mais de funcionalidade sistêmica do que outra coisa. A utopia universalista da "ordem" foi progressivamente se transformando no seu contrário, ou melhor, na sua verdade, ao se ater ao elementarismo das forma simples, ao traçado regulador e à organização das funções na cidade. Mais precisamente: foi cedendo ao formalismo integral das soluções padronizadas pela produção industrial, que aparece portanto não como uma aberração mas como a sua realização natural - do purismo corbusiano à arquitetura de Mies van der Rohe, que é apenas o capítulo conclusivo desse processo (ARANTES, 1998, p. 108).

Apesar da análise de Arantes se referir à crítica da cidade, nesse parágrafo, ela faz menção a vários pontos comentados e vividos por Lima. Entre um deles está a ideologia do funcionalismo social, que respondia ao consumo de massa e a produção industrial e em série baseado na linha de montagem. Não se dá por acaso as escolhas de Lima pela industrialização e produção da arquitetura por peças que compõe o edifício.

Além da ideologia do funcionalismo social, a autora utiliza a palavra integradora, também referida por Lima. Arantes parece colocar uma ambiguidade entre a crítica realizada por essa forma industrial de produção da arquitetura, contra as formas elaboradas até então, mas integradora para o contexto da época. Lima compreende o papel do arquiteto como integrador das necessidades do ser humano e das diversas disciplinas conhecimentos e necessários para a arquitetura. Nesse aspecto, Lima parece responder ao papel de arquiteto como proposto por Arantes, que integra ao contexto social e político daquele período.

Como Arantes denomina, a "utopia universalista", era palavra de ordem dos 
intelectuais brasileiros. Lima tinha a intenção de diminuir as desigualdades sociais, mas esta não passou de uma vontade que foi transformada segundo Arantes na "cidade padronizada e individualista", tema também citado por Lima quando comenta sobre o mundo atual e as discrepâncias entre o custo e os produtos disponíveis no mercado.

A consciência social de Lima, marcada pela vontade de promover um habitat capaz suprir as necessidades e um ambiente mais digno para o ser humano eram características próprias da década de 1960 no Brasil. Lima fez parte desse contexto e trabalhou para a produção dessa sociedade. 


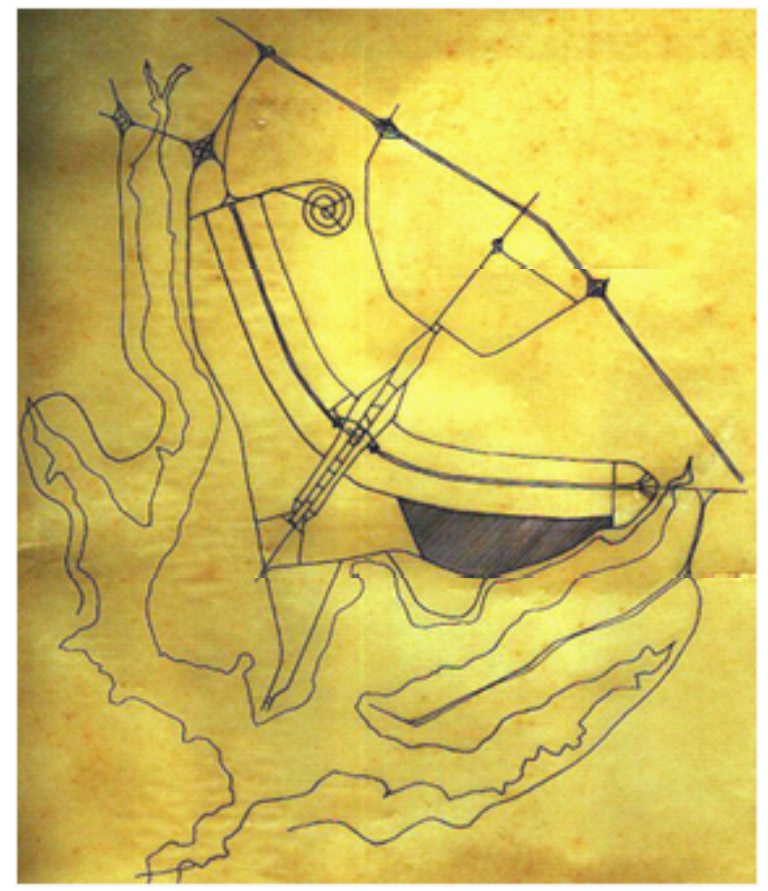

Figura 109: Localização da

Universidade de Brasília no Plano

Piloto da cidade. Fonte Ceplan

UnB. 


\subsection{O Processo Industrializado do Alojamento de Professores - Colina}

O processo de produção industrializado do habitat poderia ser visto nos trabalhos que foram projetados por Lima. Um exemplo das obras é o Alojamento para Professores da UnB que será analisada neste ítem. Estas unidades de moradia foram projetadas e construídas por J oão Filgueiras Lima em 1962 e faziam parte do plano da UnB desenvolvido por Lucio Costa (DIAS, 1970, p. 16). Conforme figura ao lado, o setor destinado a Universidade de Brasília localizava-se na Asa Norte e teria a área em extensão semelhante ao das embaixadas na Asa Sul.

A Universidade de Brasília foi baseada, segundo Darcy Ribeiro, em três modalidades: os Institutos, as Faculdades e as Unidades Complementares, como ele descreve:

Aos Institutos Centrais compete ministrar: 1. Cursos introdutórios de 4 semestres para todos os alunos da universidade, a fim de lhes dar preparo intelectual e técnico-científico básico para seguir os cursos profissionais nas faculdades; 2 . cursos de bacharelado de mais dois semestres em qualquer disciplina departamental para os alunos que desejam seguir estudos especializados ou dedicar-se à carreira do magistério; 3. Cursos de graduação científica de mais 4 semestres, após o bacharelado, para os estudantes que revelam maior aptidão para pesquisas e estudos originais e queiram obter o grau de mestre;

4. Programas de estudos pós-graduados de mais quatro semestres, após a licença para os candidatos ao doutoramento (RIBEIRO, 1963, p. 4).

De acordo com essa distribuição, seriam construídos Institutos Centrais de: Matemática, Física, Química, Biologia, Geociências, Ciências Humanas, Letras e Artes. As faculdades tinham como objetivo formar profissionais, e estavam previstas: Faculdade de Ciências Políticas e Sociais, Faculdade de Ciências 


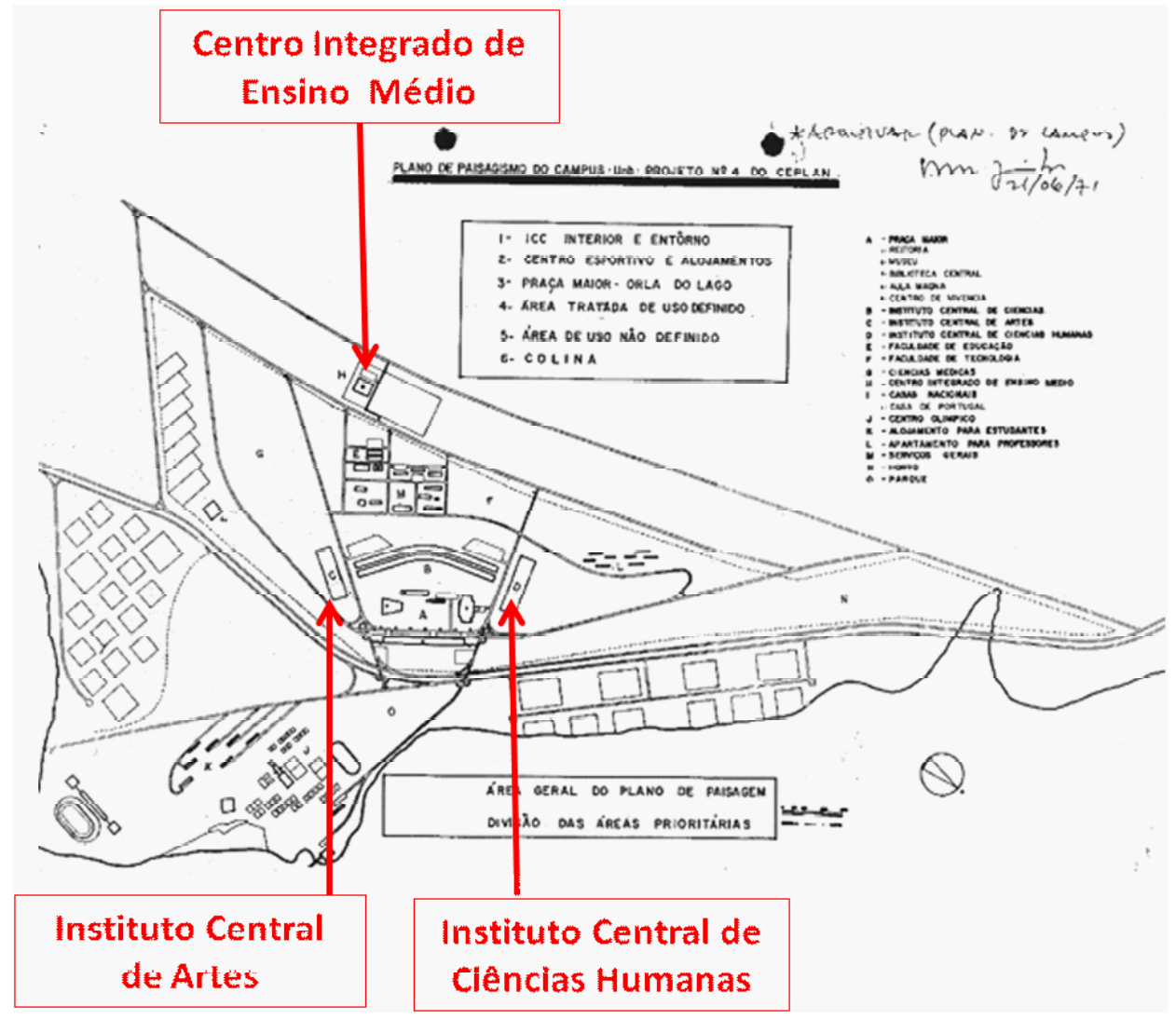

Figura 110: Plano original da UnB. Fonte: Cedoc (UnB) 


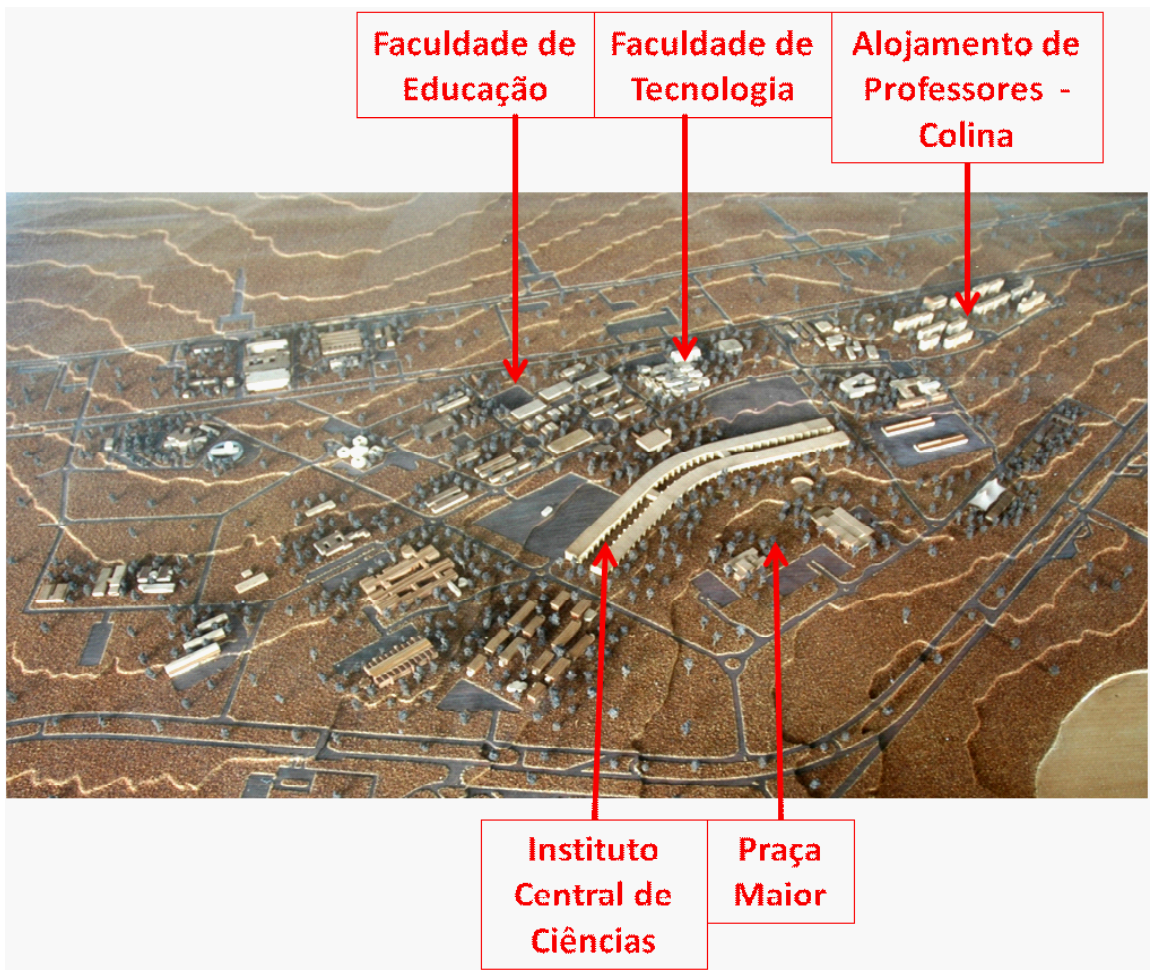

Figure 111: Maquete da atual Universidade de Brasília. Fonte: foto tirada da maquete localizada na reitoria na UnB. Acervo Pessoal (dez 2010). 


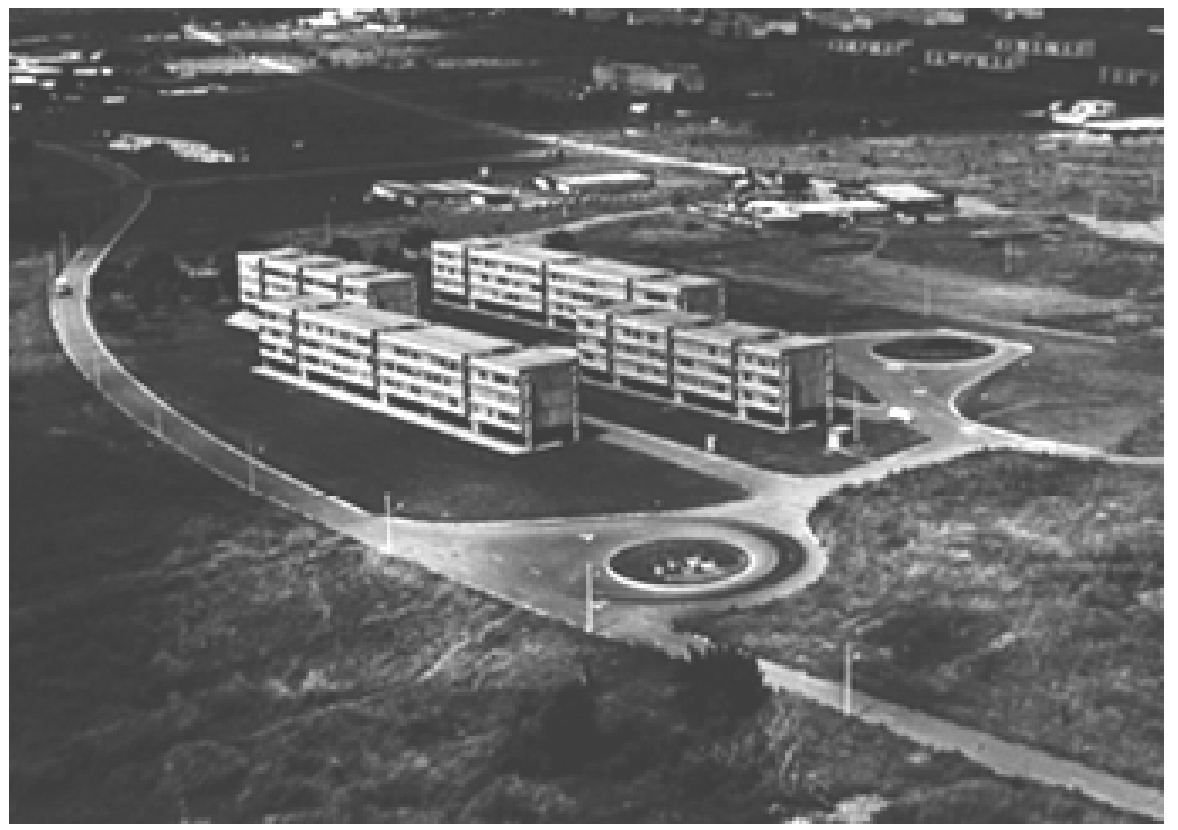

Figura 112: Vista aérea UnB -

Alojamento de Professores. Fonte:

Cedoc UnB. 


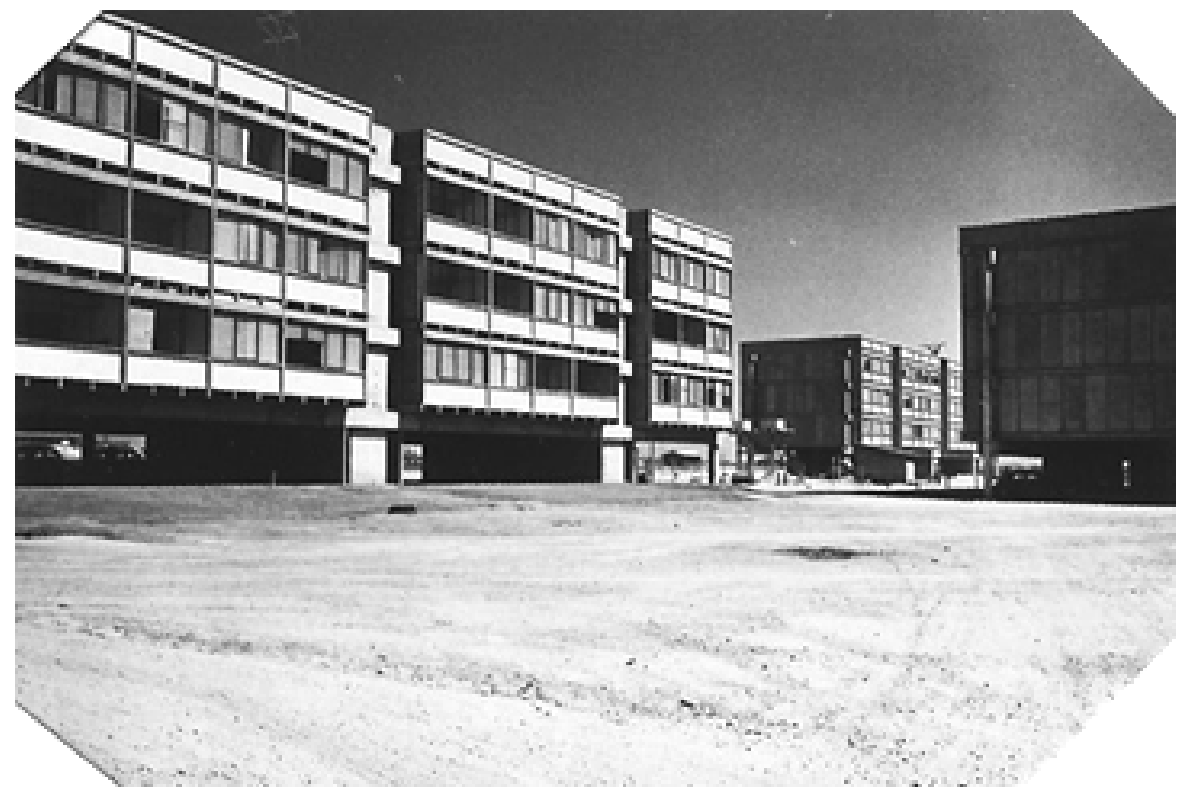

Figura 1113 Vista Geral dos Apartamentos. Fonte: Cedoc UnB. 

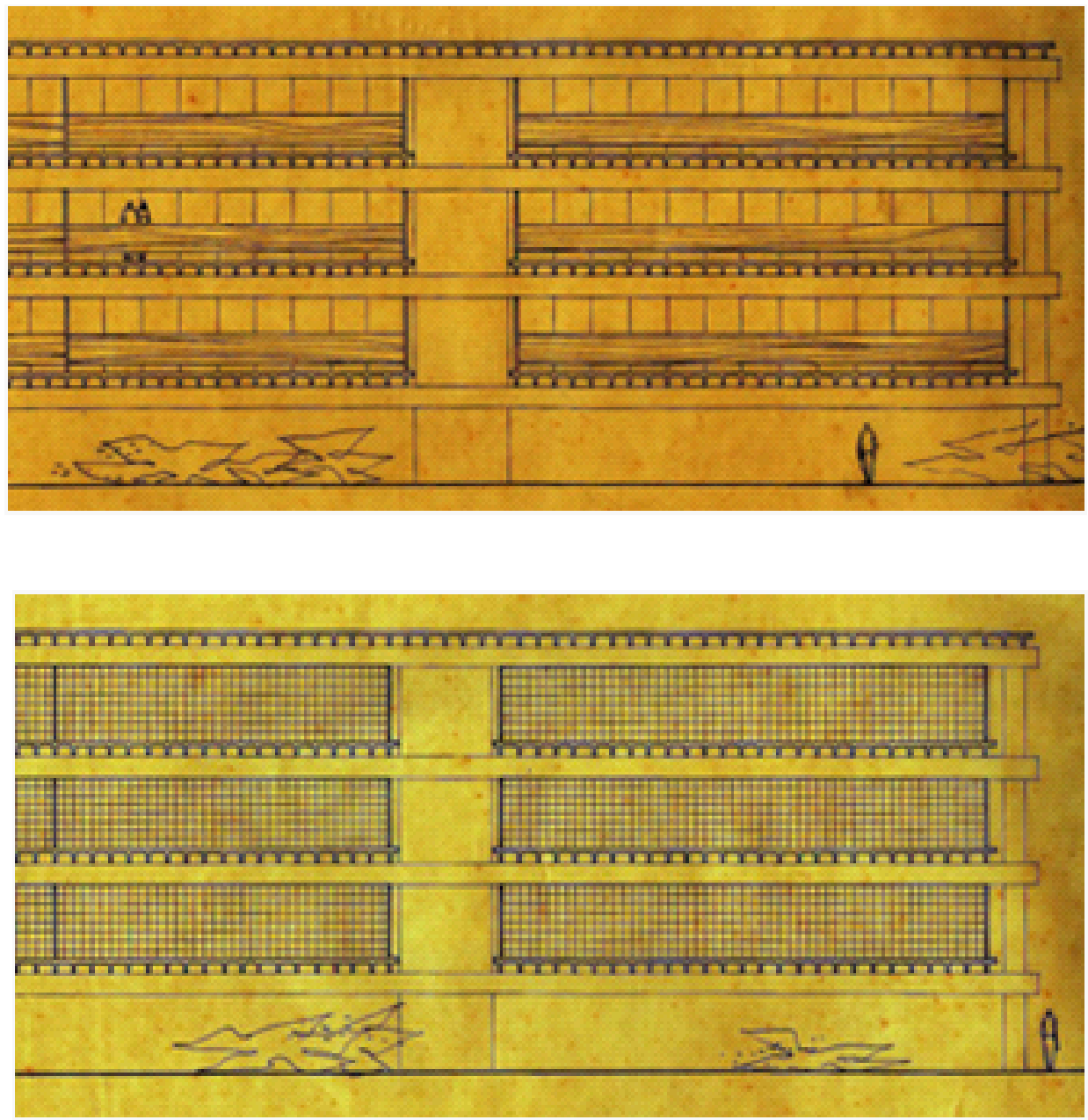

Figura 114: Vista Leste. Fonte : Ceplan UnB.

Figura 115: Vista Oeste. Fonte: Ceplan UnB. 
Médicas, Faculdade de Ciências Agrárias, Faculdade de Tecnologia, Faculdade de Arquitetura e Urbanismo e Faculdade de Educação.

A organização do plano da Universidade foi de autoria de Lucio Costa, e os edifícios foram desenvolvidos por vários arquitetos que estavam sob a coordenação de Oscar Niemeyer no Centro de Planejamento (Ceplan). Como tratado anteriormente, esse órgão tinha o intuito de projetar os edifícios de Brasília de acordo com o Plano Piloto.

Os Alojamentos da Colina foram estrategicamente construídos como prioridade na Universidade, pois seriam atrativos para os docentes vindos de outros locais do país. O projeto tinha quatro blocos de apartamentos destinados para professores e funcionários da UnB.

De acordo com o arquiteto,

Os prédios liberam quase totalmente as áreas dos pavimentos térreos para estar, jardins e abrigo de automóveis.

Os apartamentos do primeiro conjunto construído são de três tipos: 1 com $144 \mathrm{~m}^{2}, 2$ com $108 \mathrm{~m}^{2}$ e 3 com $84 \mathrm{~m}^{2}$.

As áreas correspondentes a sala e quartos são flexíveis permitindo que o dimensionamento dessas peças se ajuste corretamente ao programa de cada professor (LIMA, 1970, p. 33).

Como mostram as figuras a seguir as diferentes configurações de apartamentos com mobiliário. Na Planta 1 observa-se a configuração de um alojamento, com pequenos quartos, os banheiros e cozinha são coletivos; a área que seria destinada ao depósito e lixo é aproveitada na cozinha. A configuração da Planta 2 , do apartamento com três quartos e quarto de empregada é destinada a funcionários ou professores hierarquicamente superiores, que viriam com suas famílias para trabalhar na cidade. Esses apartamentos poderiam ter um depósito entre os dois últimos quartos, e a entrada de serviços poderia ser em frente a escada com uma 


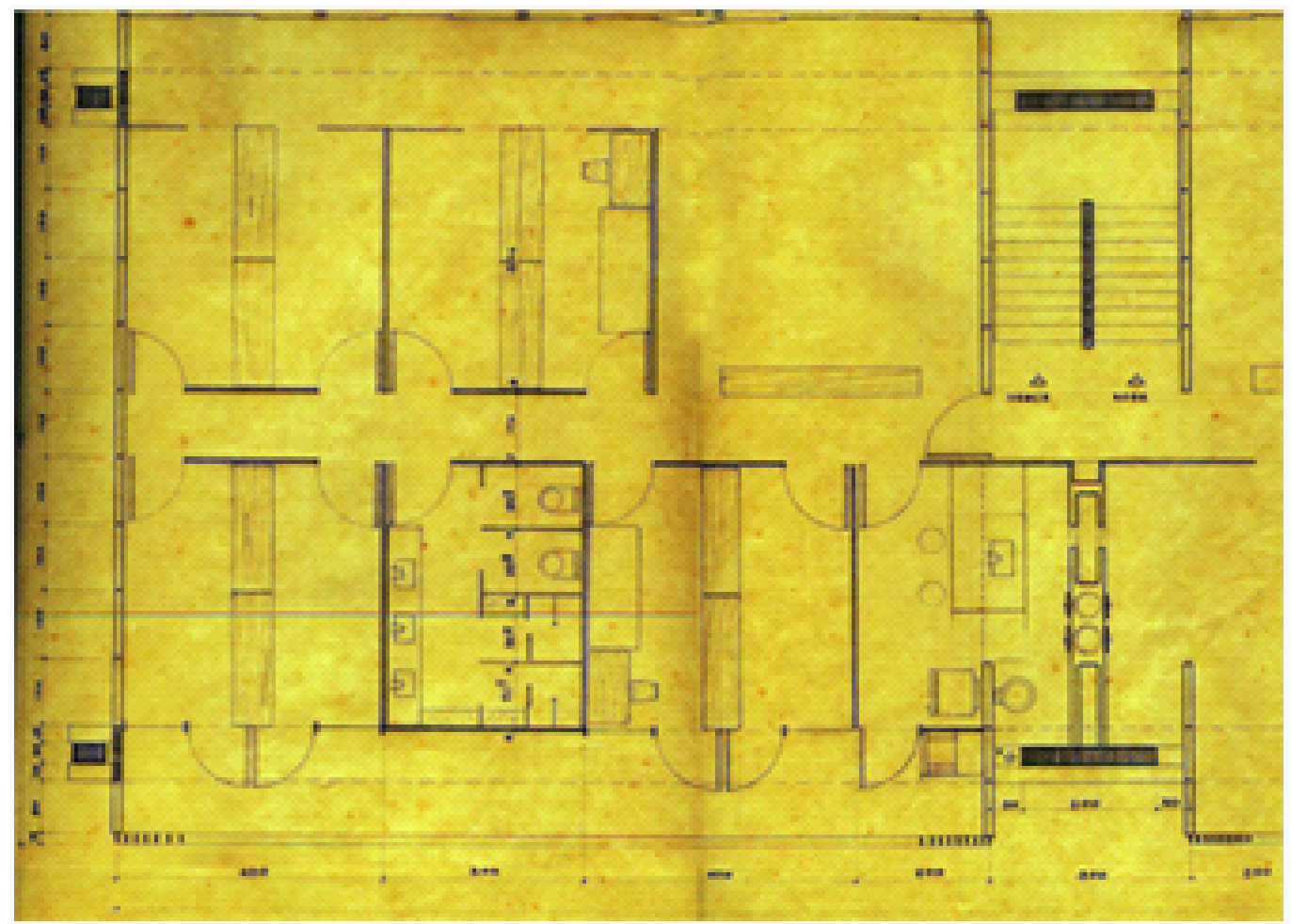

Figura 116: Planta 1 - Alojamento

Coletivo. Estar, quartos, varanda, banheiro coletivo, quartos, cozinha, área serviço e varanda. Fonte

Ceplan UnB. 


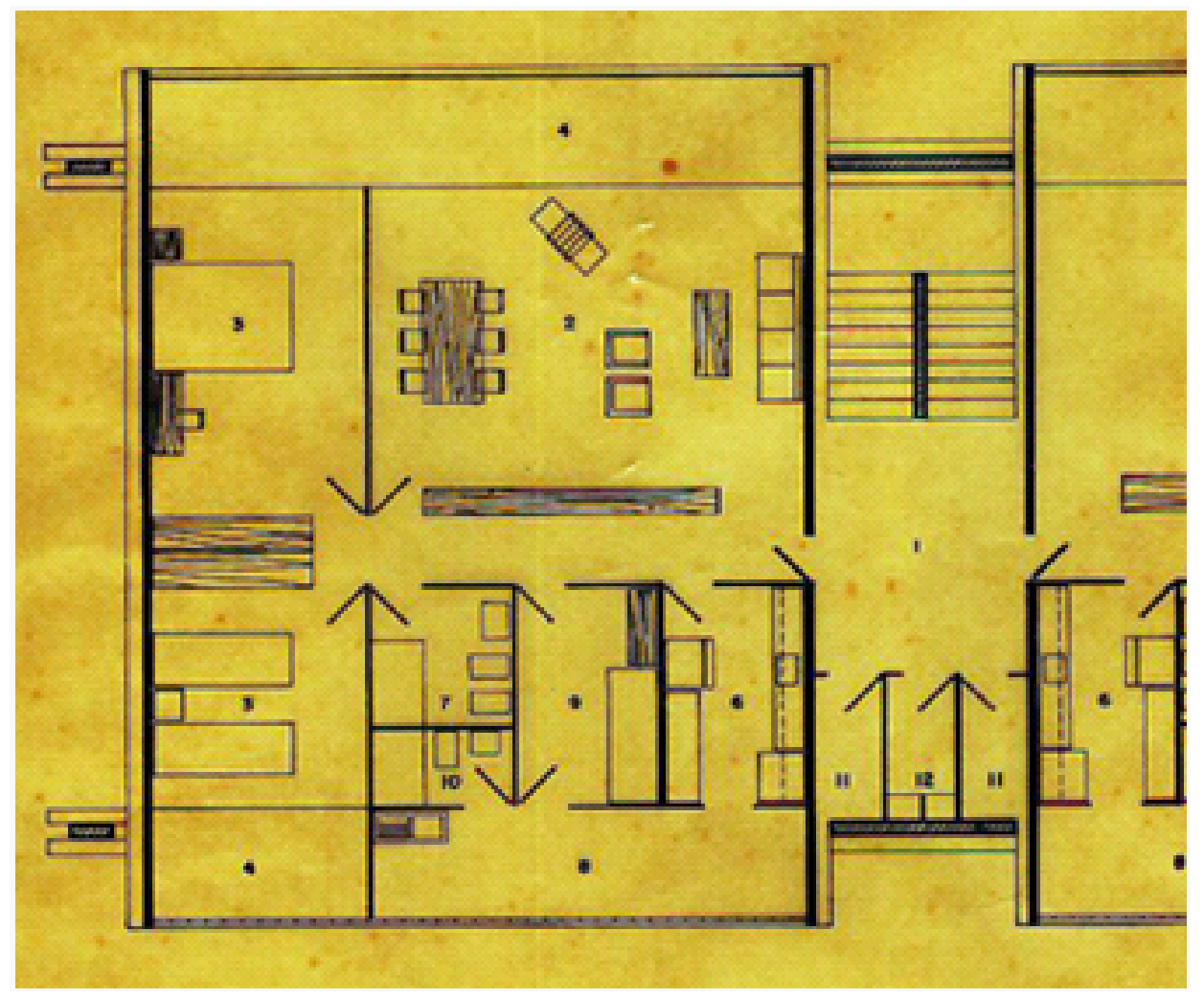

Figura 117: Planta 2 - Três quartos. Estar e jantar, varanda escritório, quartos, banheiro, cozinha, quarto serviço, banheiro serviço e área de serviço. Fonte Ceplan UnB. 


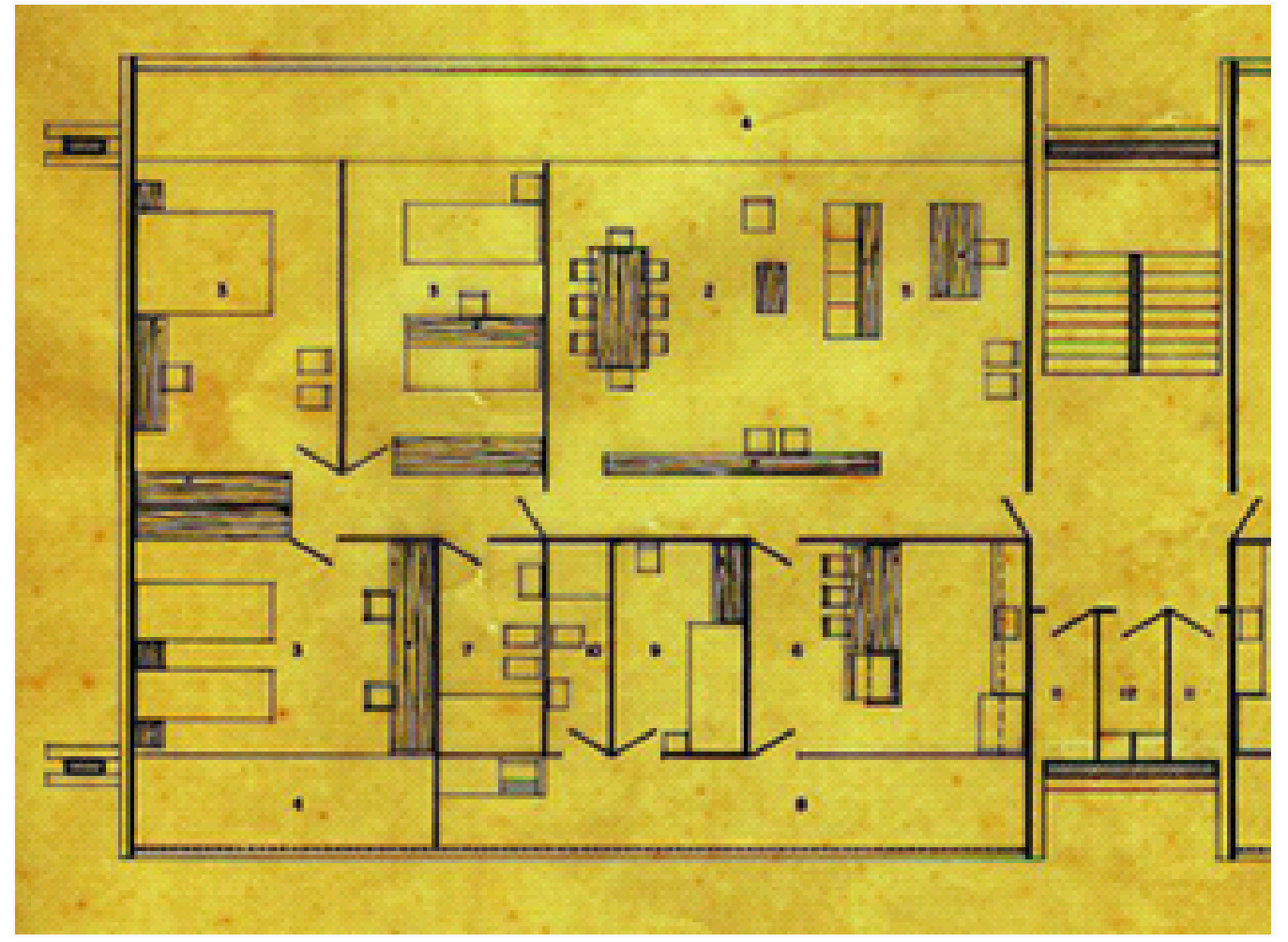

Figura 118: Planta 3 - Dois quartos.

Estar, varanda, quartos, banheiro,

quarto opcional para serviço,

cozinha, serviço, depósito e lixo.

Fonte Ceplan UnB. 


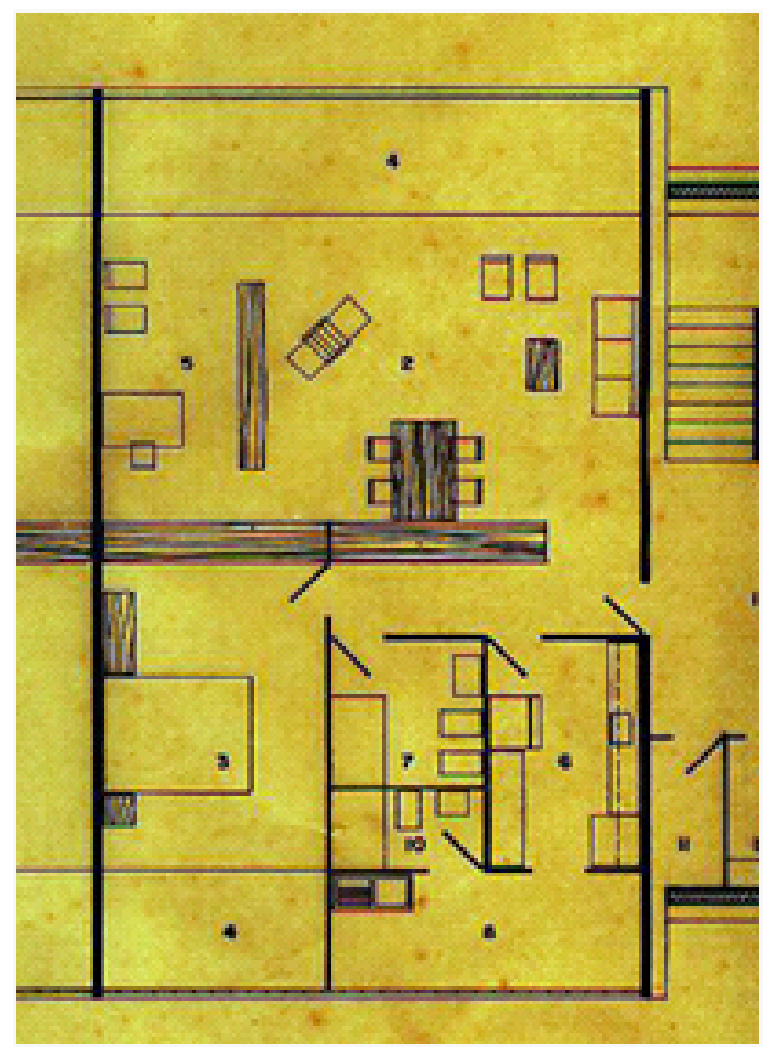

Figura 119: Planta 4 - Um quarto - estar, escritório conjugado, varanda, quarto, banheiro, cozinha, área serviço e banheiro de serviço. Fonte Ceplan UnB. 

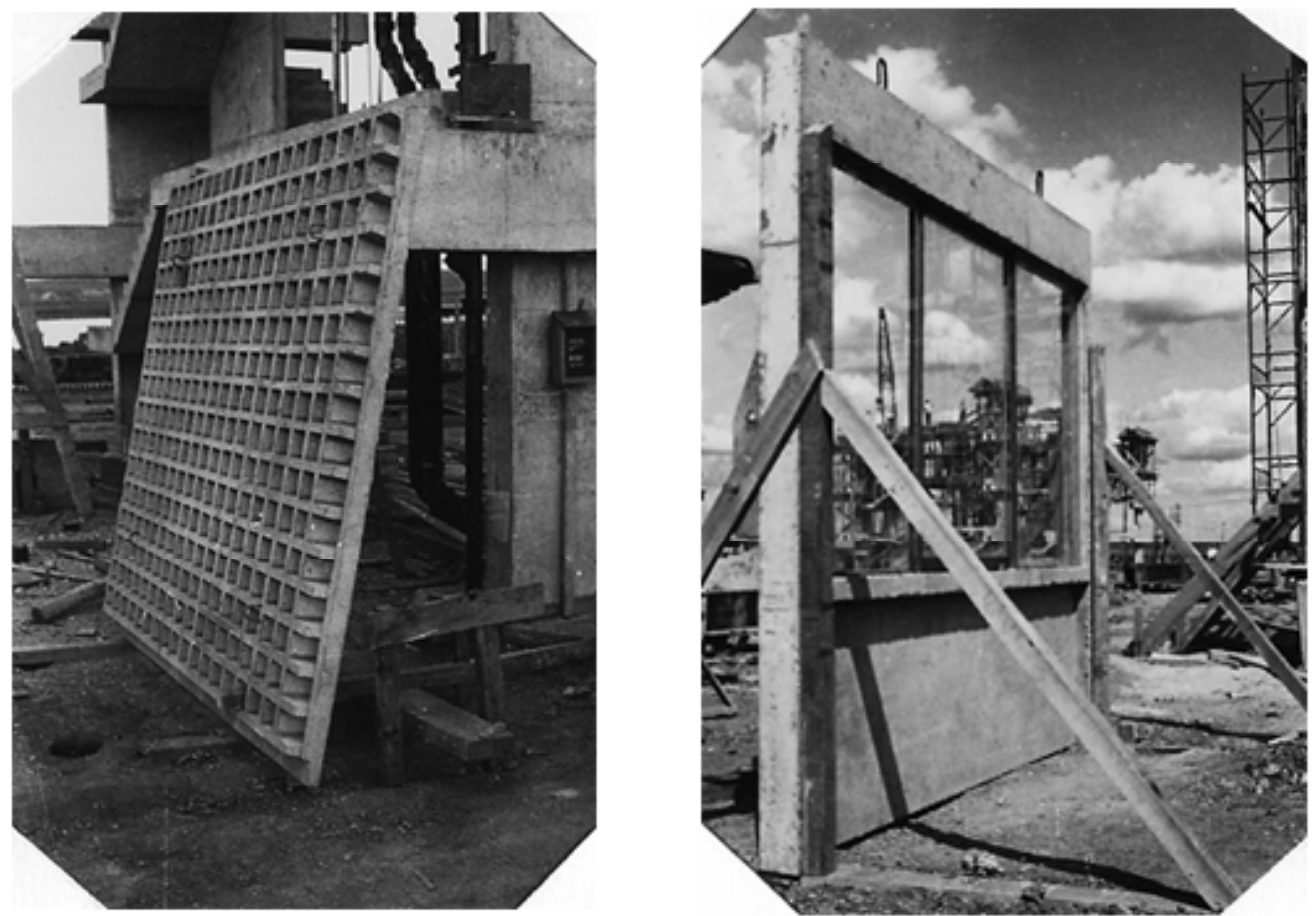

Figura 120: Peça cobogó face oeste. Fonte: Cedoc UnB.

Figura 121: Peça esquadria face leste. Fonte: Cedoc UnB. 


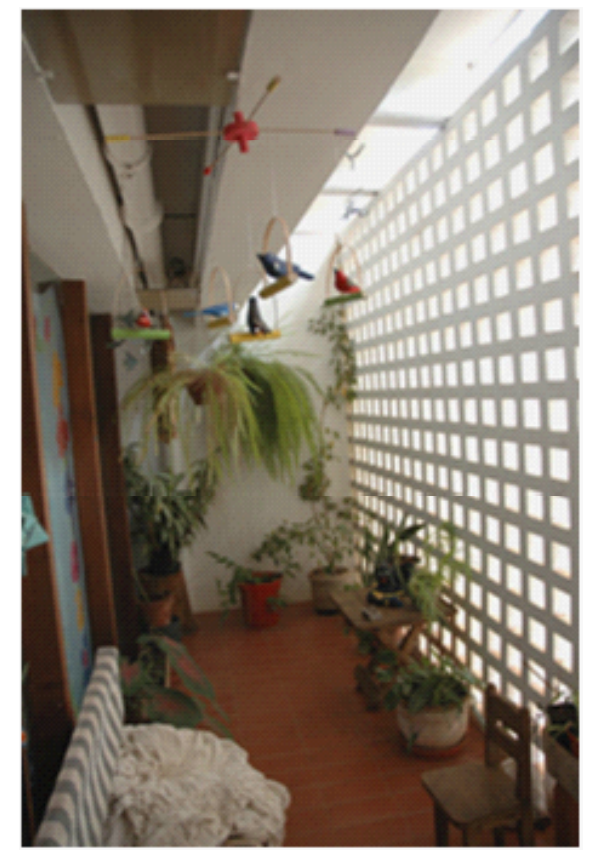

Figure 122: Vedação de cobogó e viga com instalações aparentes.

Fonte: acervo pessoal.

abertura para a cozinha.

As tipologias da Planta 3 com dois quartos e da Planta 4 com um quarto eram semelhantes. Alteravam-se na presença da área de trabalho e quarto reconfigurável para empregada. Os apartamentos apresentavam circulação central, que distribuía para os ambientes. Os armários eram elementos utilizados para separar os espaços. Em frente a escada havia um depósito para cada apartamento e o lixo era descartado no local entre os depósitos da escada por dutos que chegavam ao pavimento térreo. 

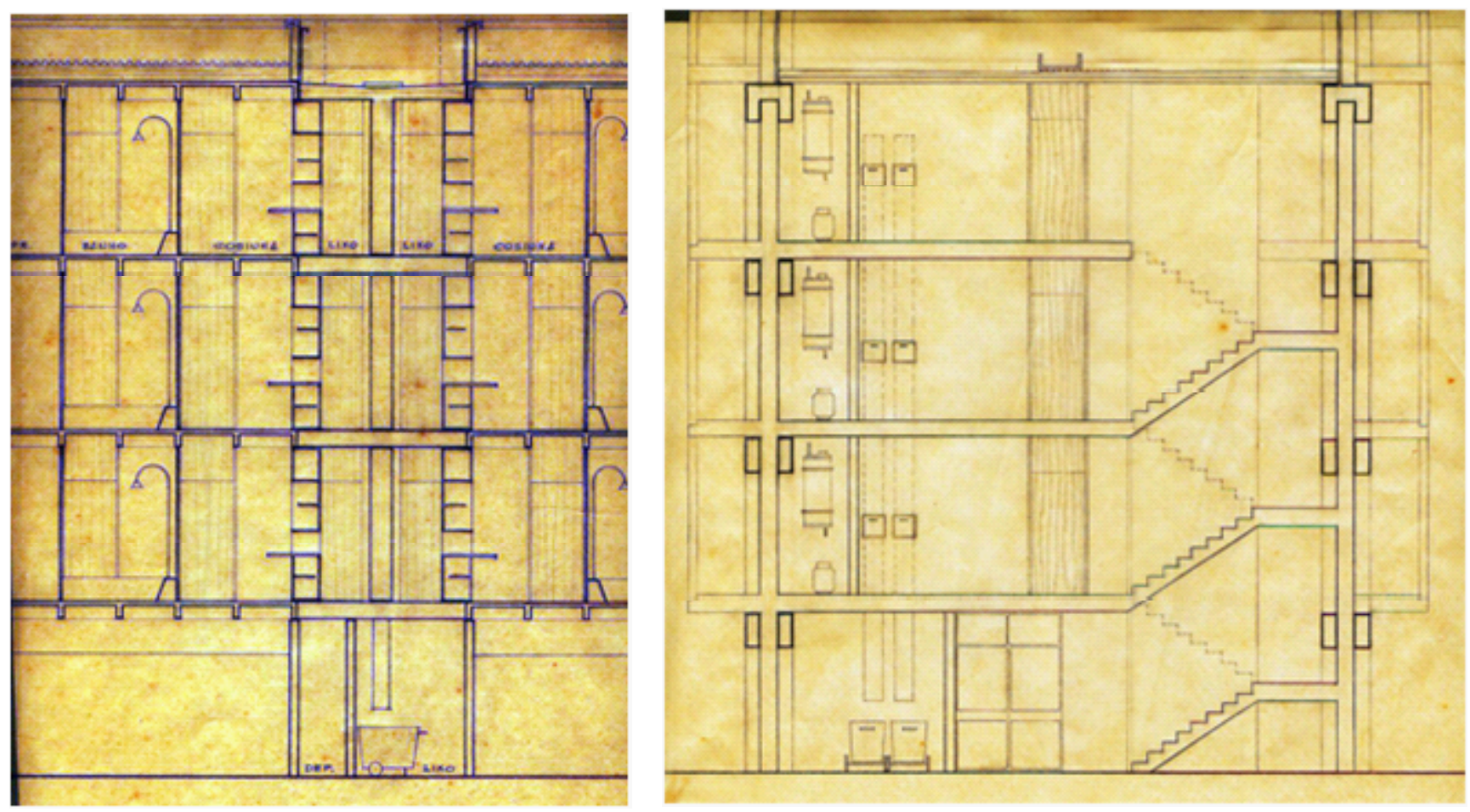

Figura 123: Corte Longitudinal escada. Fonte Ceplan UnB.

Figura 124: Corte transversal escada. Fonte Ceplan UnB 


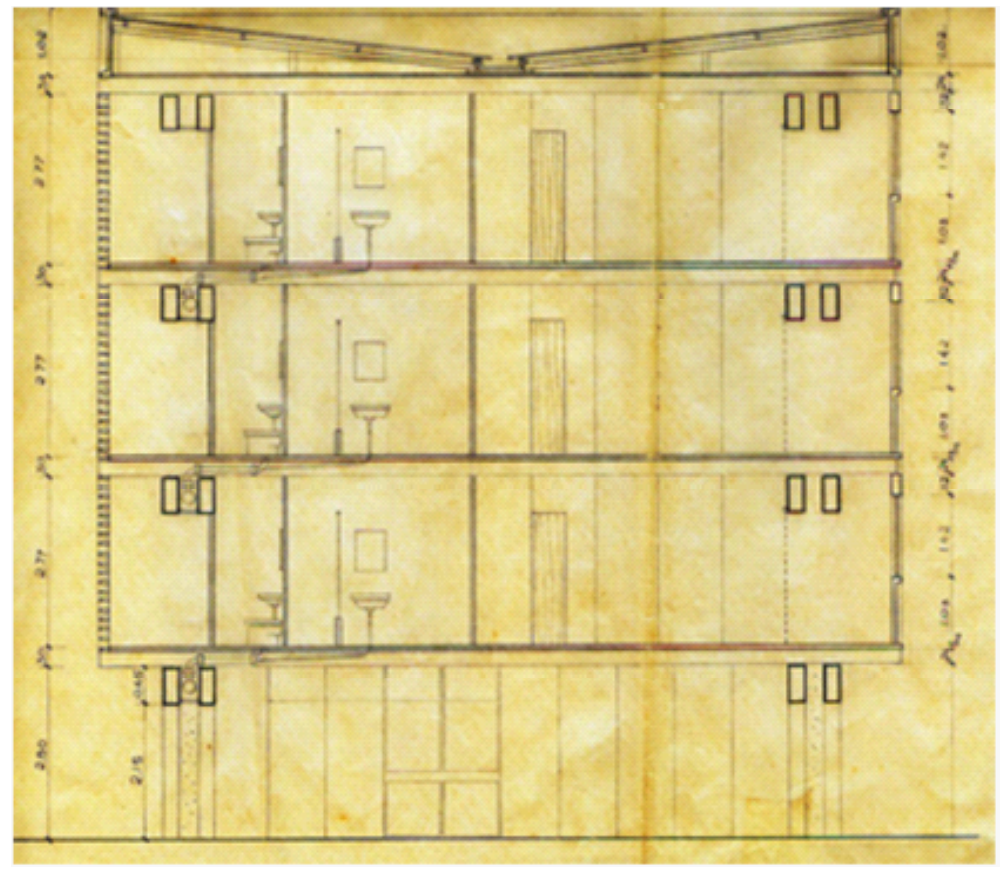

Figura 125: Corte transversal. Fonte Ceplan UnB. 

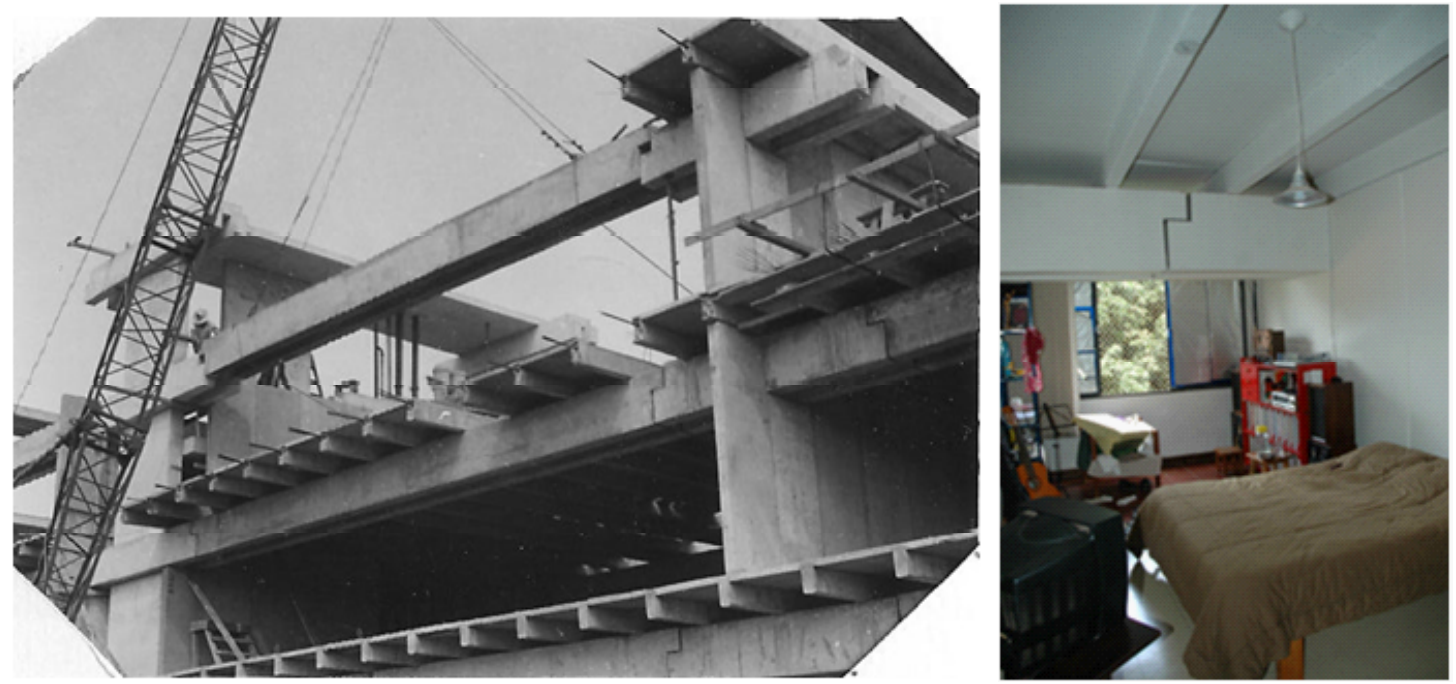

Figura 126: Colocação da viga "U". Fonte: Cedoc UnB.

Figure 127: Quarto com viga aparente e rótula Gerber. Divisão entre ambientes de painel. Fonte: acervo pessoal. 
As varandas eram espaços pensados de ambos os lados do apartamento. $\mathrm{Na}$ face leste, o fechamento era com esquadrias metálicas e vidro e na face oeste de maior insolação Lima elaborou uma peça vazada pré-fabricada (Cobogó) conforme mostrado nas vistas dos edifícios e nas peças abaixo.

A cobertura era protegida por telhas de fibrocimento e ocultadas por platibanda. As instalações eram encaixadas entre as vigas de concreto. $O$ edifício da Colina foi estruturado a partir da caixa de escada fundida no local para contraventamento e fixação da estrutura pré-fabricada de pilares e vigas.

O sistema pré-fabricado em concreto utilizado para construir os edifícios previa a elaboração de formas metálicas para as peças que seriam reproduzidas em escala. Os componentes básicos que constituíam o edifício eram as vigas com rótula Gerber ${ }^{22}$, as lajes nervuradas e as placas de vedação lateral.

Como descreve Lima,

A construção desses apartamentos será simples e econômica.

A estrutura pré-fabricada utiliza, dentro das possibilidades da maquinaria, grandes elementos pré-moldados. Assim, colunas, vigas, lajes e os próprios caixilhos das esquadrias são de concreto armado, o que permite construção rápida e os preços desejados. O sistema estrutural compreende colunas espaçadas de 15 em 15 metros e vigas duplas longitudinais, sobre as quais se distribuem as placas nervuradas dos pisos. A não ser nas extremidades do bloco, os apoios se adaptam aos acessos verticais, o que evita colunas e soluciona de forma prática os problemas de contraventamento. (LIMA, 1963, p. 39)

Vigas Gerber são frequentemente utilizadas na construção civil industrializada por possibilitar a estabilidade através de dois pontos fixos. No caso dos Alojamentos,

22 A viga Gerber se constitui num caso particular de estruturas compostas. Consta de uma associação de vigas com estabilidade própria, com outras, sem estabilidade própria apoiadas sobre as primeiras, dando estabilidade ao conjunto. A interligação entre as partes se dá por intermédio das articulações (rótulas). Nesta associação, as vigas com estabilidade própria suprem as outras dos vínculos que Ihes faltam, ficando o conjunto estável, portanto, as primeiras são acrescidas de cargas que Ihes são transmitidas pelas rótulas. 

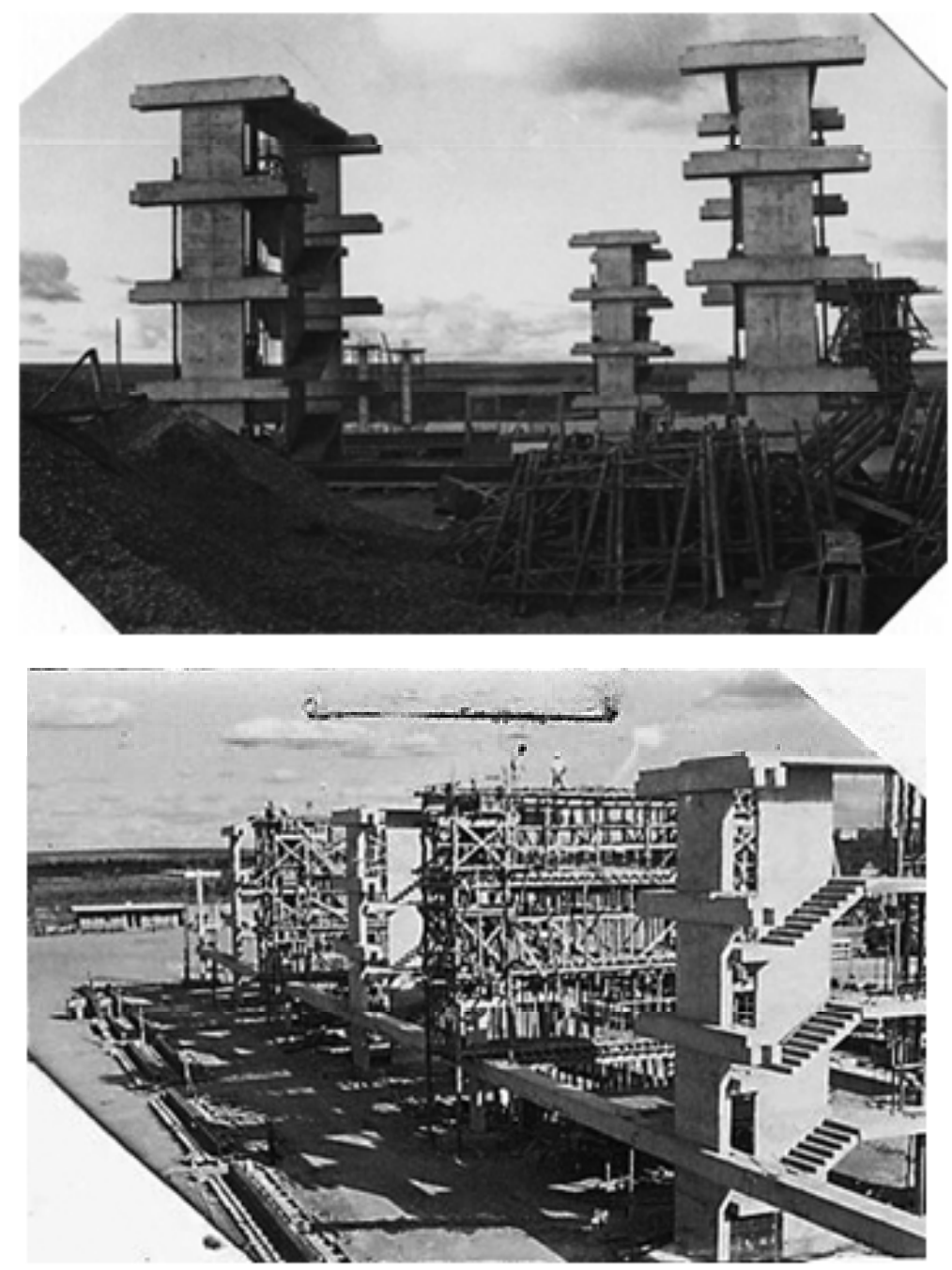

Figura 128: Caixa de escada. Fonte: Cedoc UnB.

Figura 129: Colocação das vigas. Fonte: Cedoc UnB. 

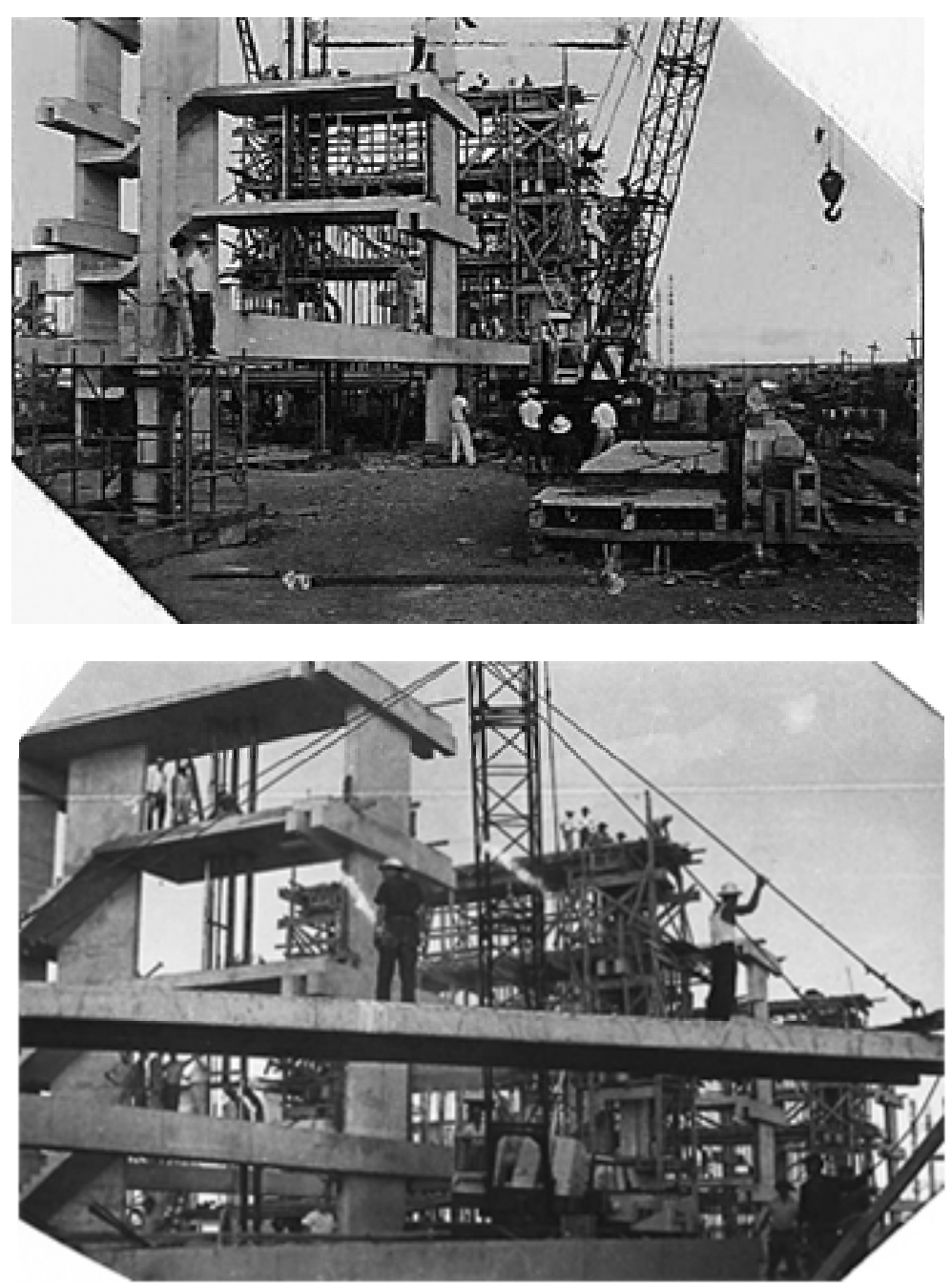

Figura 130: Sistema estrutural, colocação das vigas. Fonte: Cedoc UnB.

Figura 131: Viga transportada por guindaste. Fonte: Cedoc UnB. 


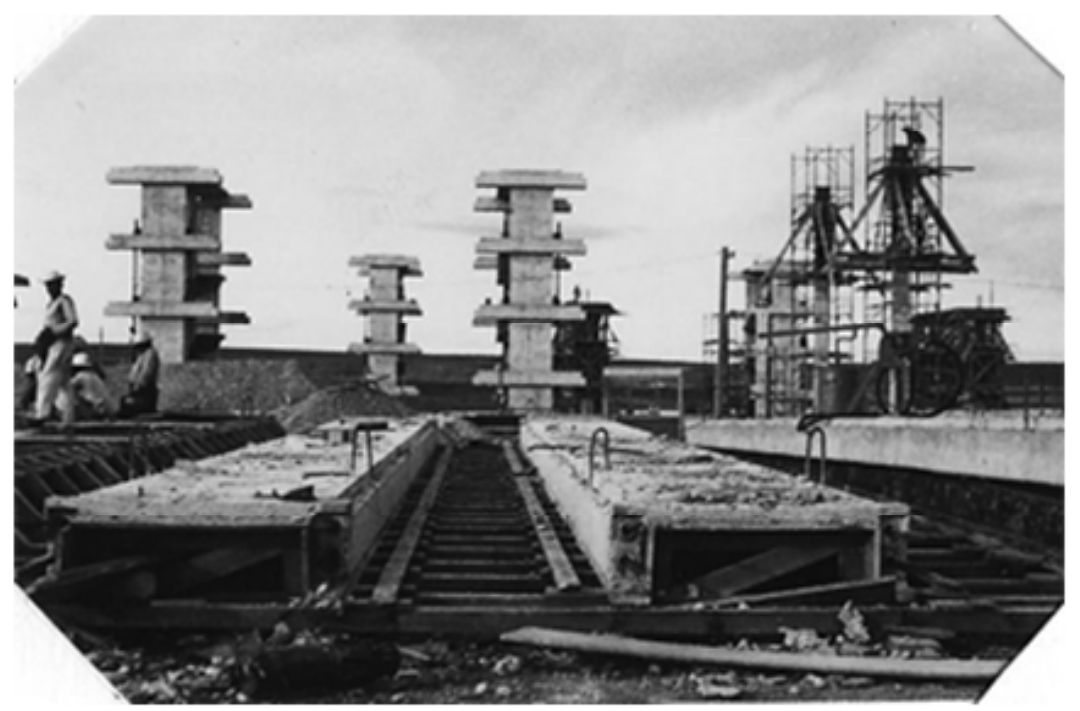

Figura 132: Laje nervurada prémoldada.Fonte: Cedoc UnB.

Figura 133: Colocação de laje de piso. Fonte: Cedoc UnB.

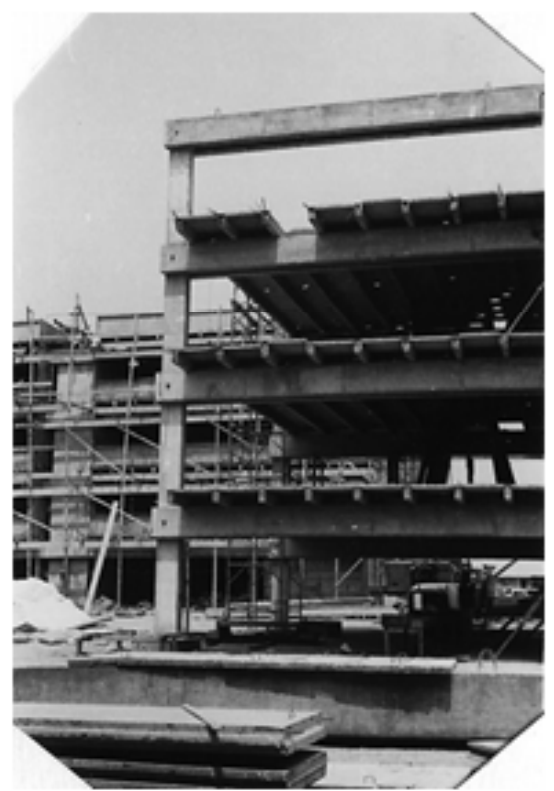


os pontos estáveis eram dados pela estrutura da escada que garantia o esforço realizado pela viga. Esta viga fica aparente nos ambientes internos do apartamento, explicitando o sistema estrutural do edifício.

As vigas eram presas aos pilares com um pino de aço, e tinham como referência a fixação utilizada com madeira.

As lajes nervuradas e protendidas pré-fabricadas eram sobrepostas às vigas, fabricadas no chão, e içadas por guindastes. Tinham o formato "C". Após a locação dos elementos, recebiam o contra-piso e o piso.

Os painéis de vedação também pré-fabricados eram colocados após a locação das peças de laje. Suspensos por guindastes eram encaixados na parede sobre a laje de piso.

Em aproximadamente um ano os alojamentos foram construídos em sistema préfabricado em concreto armado. Os projetos pesquisados datam de fevereiro de 1962, e os apartamentos foram inaugurados em 1963. Eles tinham uma extensão de $3250 \mathrm{~m}^{2}$ de área construída. Esse sistema era considerado um avanço na construção civil, pela diminuição dos custos, agilidade e soluções tecnológicas.

A descrição dos edifícios é encontrada no site da Universidade como:

Este edifício compõe, junto com os blocos B, C e D a chamada "Colina Velha", conhecida desta forma por ter sido construída bem antes do resto da colina (área residencial para professores e altos funcionários da UnB). Os quatro edifícios têm pilotis e cada um possui três pavimentos. Os prédios foram montados como móveis de madeira, peças horizontais e verticais unidas por parafusos. As peças prémoldadas de concreto armado incluíam as vigas " $U$ " (protendidas, de $14 \mathrm{~m}$ de comprimento, nas quais se apóia a laje nervurada, que constitui o piso dos apartamentos), além de elementos de esquadria e vedação, painéis de paredes, etc. As instalações elétricas e hidráulicas alojam-se aparentes, no interior da viga " $U$ " e são ligadas aos ramais 

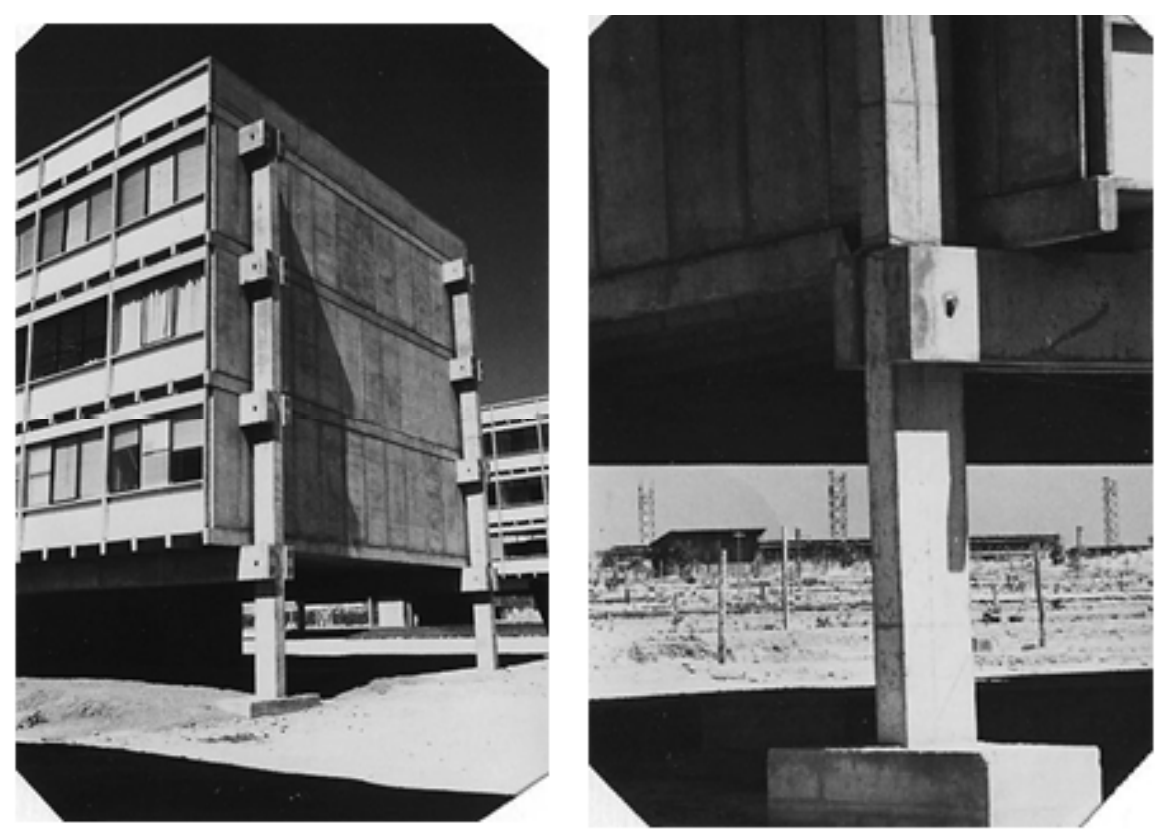

Figura 134: Elevação face pinos e painel de vedação.

Fonte: Cedoc UnB.

Figura 135: Relação viga estrutural e pilar. Fonte: Cedoc UnB. 


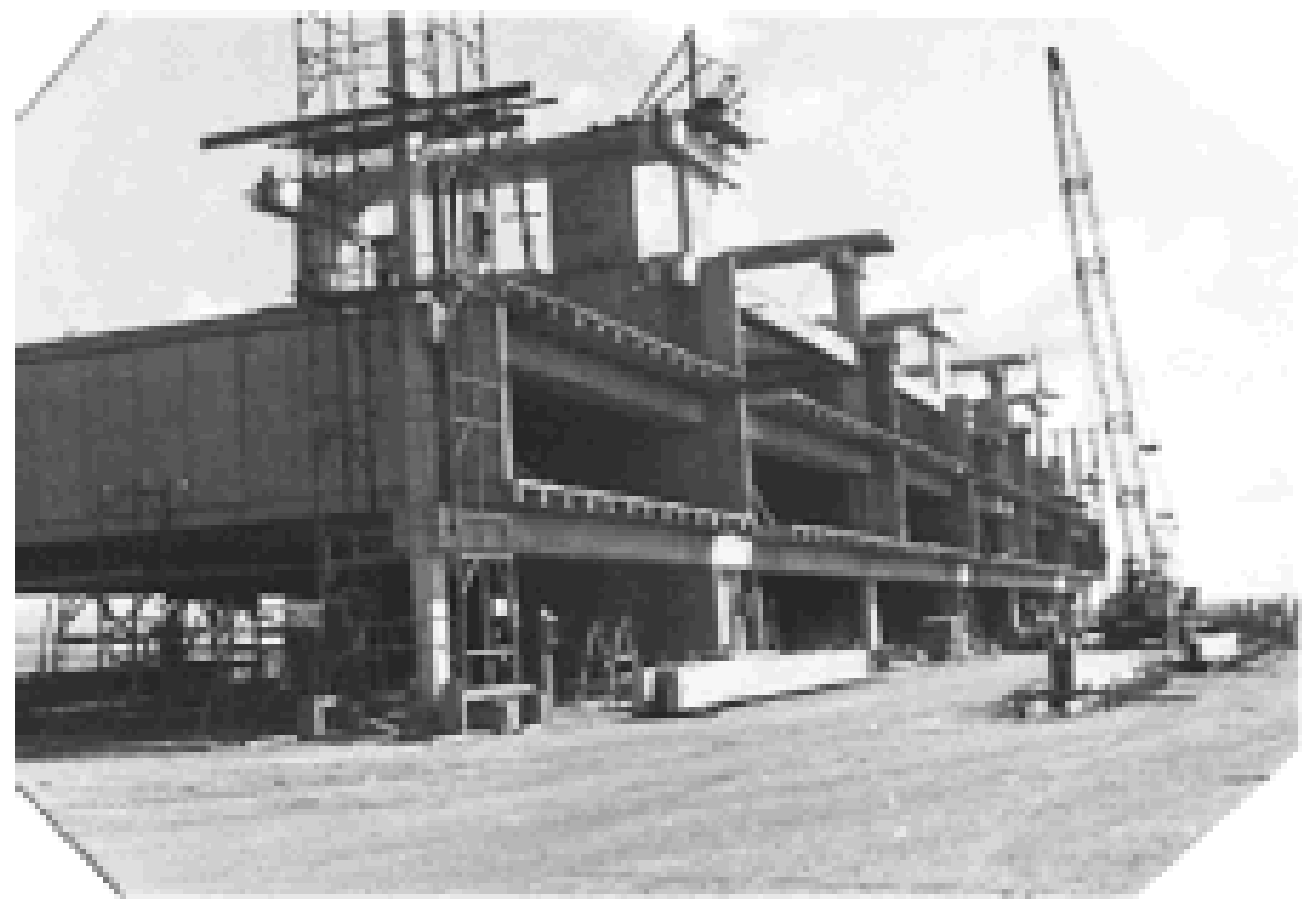

Figura 136: Colocação segunda laje. Fonte: Cedoc UnB 

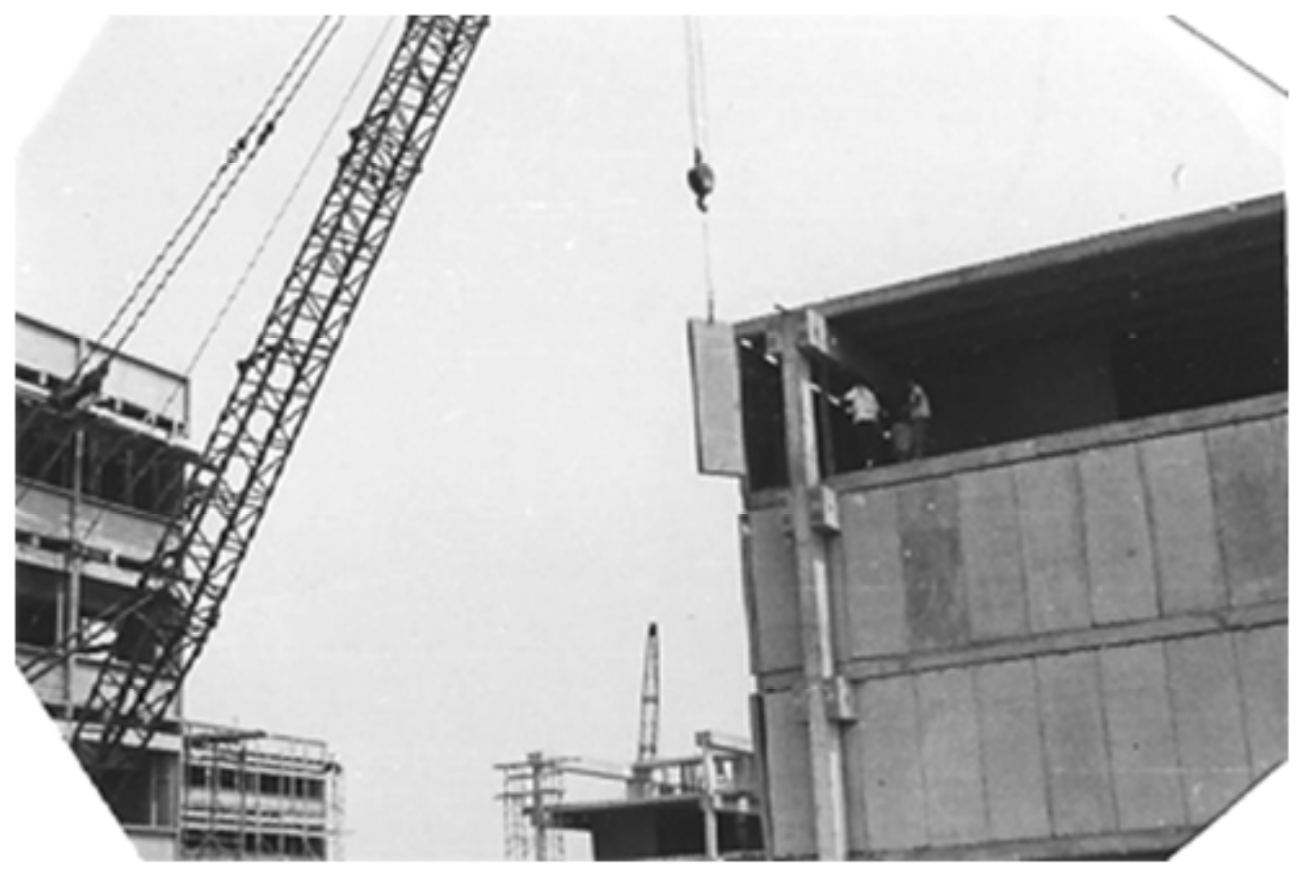

Figura 137: Colocação painéis laterais de vedação. Fonte: Cedoc UnB. 

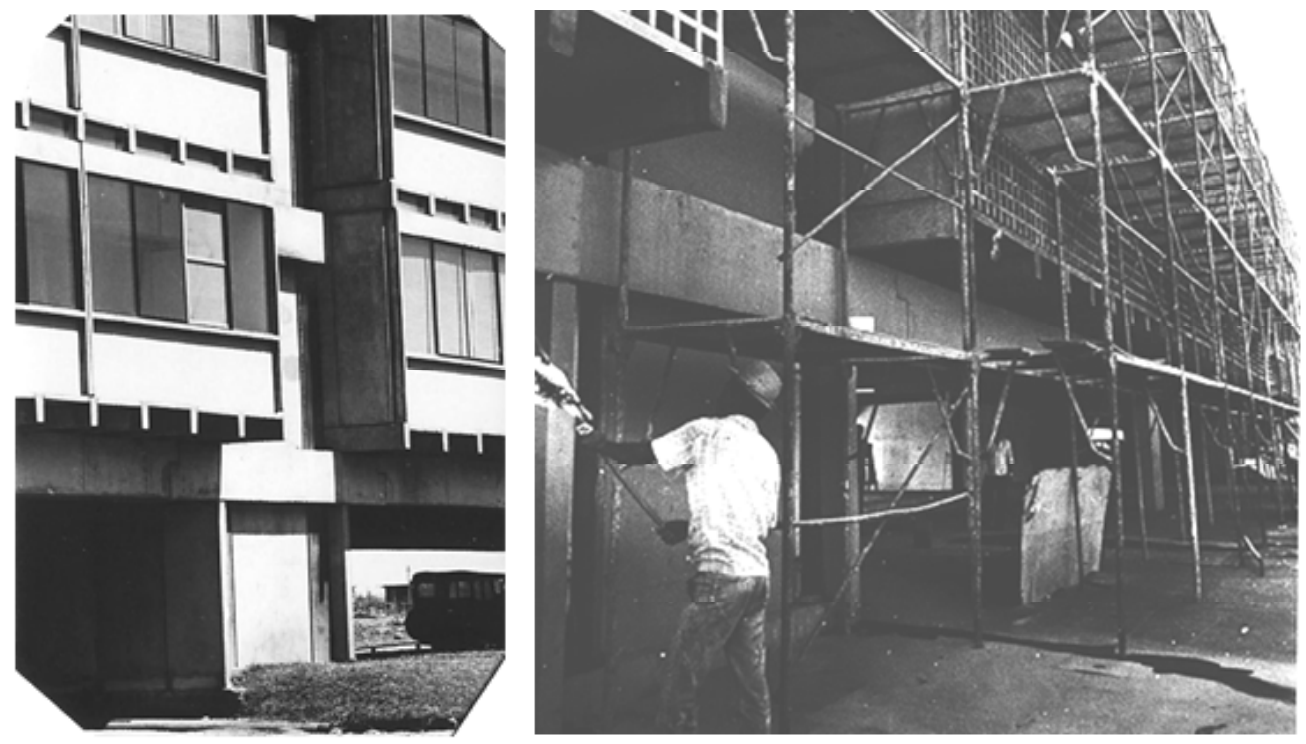

Figura 138: Face leste escada. Fonte: Cedoc UnB.

Figura 139: Pintura do edifício. Fonte: Cedoc UnB. 

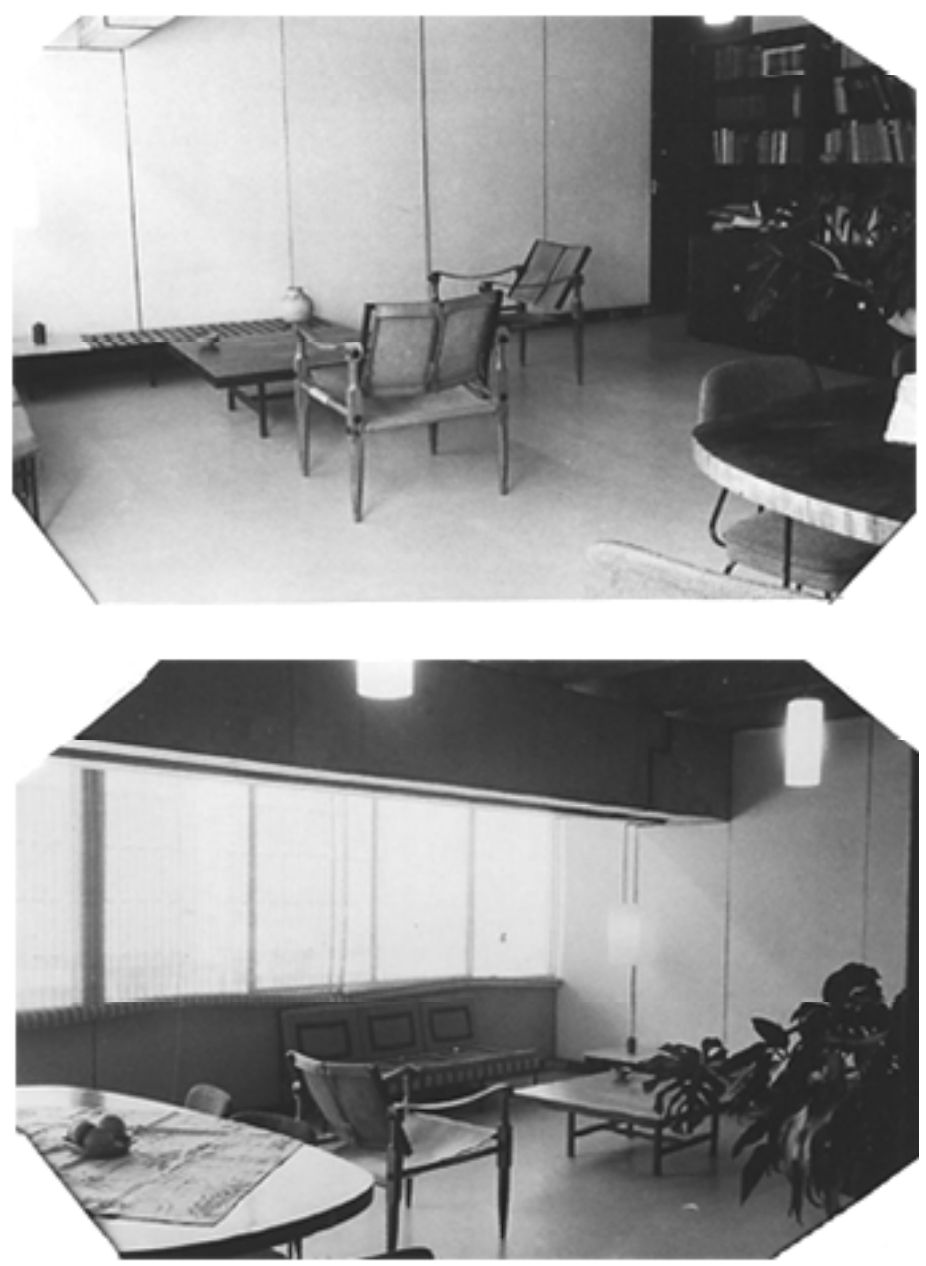

Figura 140: Vista interna do apartamento, face do armário.

Fonte: Cedoc UnB.

Figura 141: Vista interna do apartamento, face da esquadria. Fonte: Cedoc UnB. 
verticais localizados nos conjuntos de circulação vertical. As vedações das áreas de serviço são peças pré-moldadas de cobogó. As torres de circulação, de concreto armado fundido in loco são usadas como contraventamento do conjunto (UnB, 2011).

Lima iniciou sua experiência de pré-fabricação no período da década de 1960, e o desenvolvimento dos desenhos incluíam peças robustas como: vigas, lajes e painéis, e peças mais delgadas como: armários de dormitórios, armários de cozinha, armários de estar, corrimão, placas de piso e portas.

De acordo com um documento de Ismael Magalhães Mendes, engenheiro civil e membro da Faculdade de Tecnologia, o processo industrializado ${ }^{23}$ usado na construção da Colina era a:

[...] primeira tentativa séria de industrializar a construção civil e melhorar-Ihe a produtividade, pois, atualmente, os métodos de trabalho são os mais rudimentares(MENDES, 1964, p.1).

E ainda colocava como benefícios a economia de mão-de-obra e material, a não necessidade de acabamentos, revestimentos, escoramentos e portanto uma solução para o desenvolvimento nacional.

Nesse edifício pode-se perceber algumas características de J oão Filgueiras Lima que se potencializariam e definiriam sua maneira de fazer no decorrer dos anos. Uma primeira característica seria a matéria-prima dos componentes de cimento e aço. Esse material passaria para a argamassa-armada e se consolidaria nas obras da Fábrica da Companhia de Renovação Urbana de Salvador (Reurb) de 1978 a 1982 onde Lima atuou na urbanização de áreas de difícil acesso.

A utilização da estrutura metálica foi gradativa, estavam presentes nas passarelas ${ }^{24}$

23 Documento apresentado na íntegra em anexo.

24 As passarelas foram construídas desde 1986 a 1988 pela Fábrica de Escolas e Equipamentos Urbanos. As passarelas foram construídas com uma treliça metálica que se apoiava em rótulas que redirecionariam o usuário. Possuem peças de argamassa armada de cobertura e piso antiderrapante. 

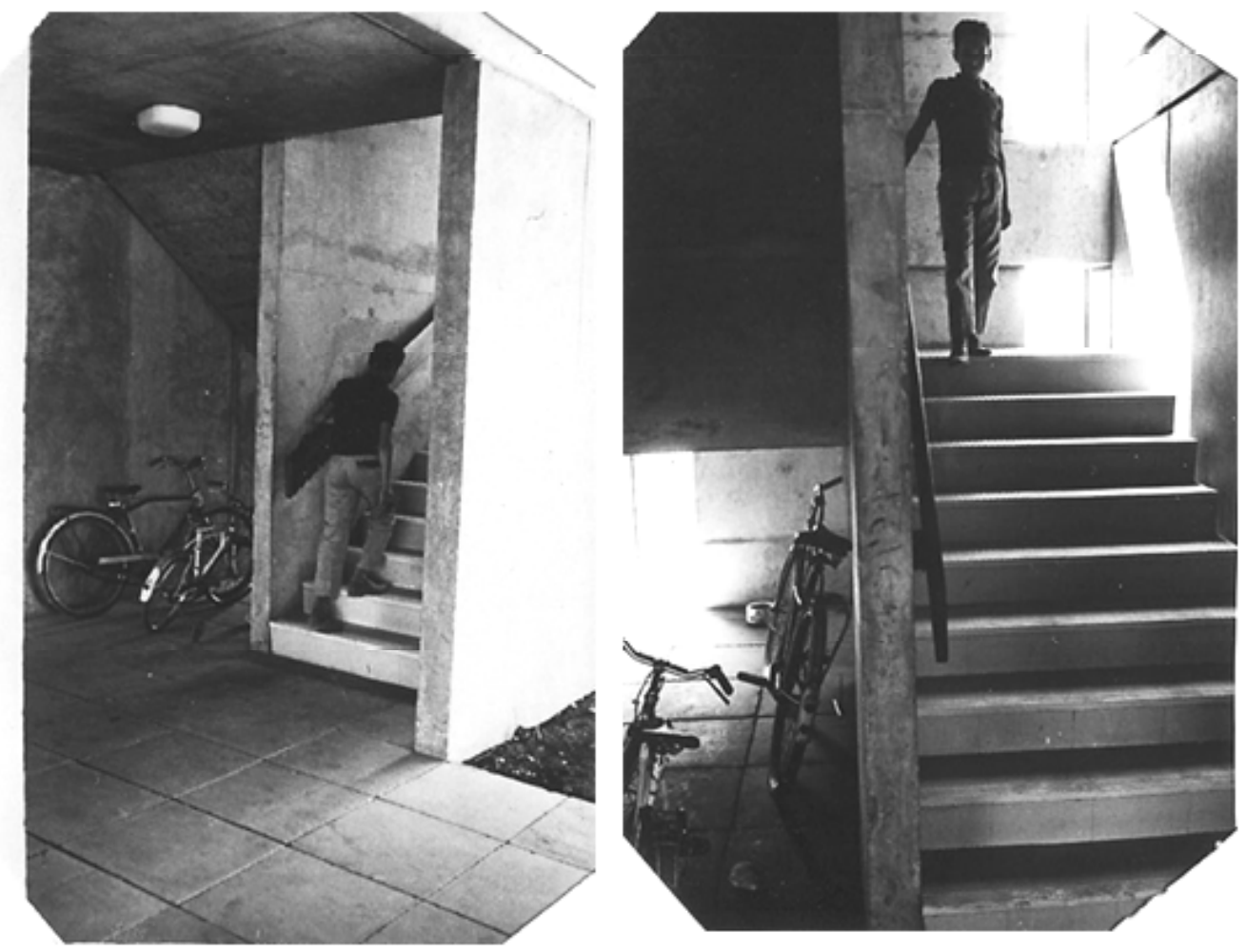

Figura 142: Escada pavimento térreo e piso pré-fabricado. Fonte: Cedoc UnB.

Figura 143: Escada pavimento térreo. Detalhe da escala; do lado oposto ao corrimão a escada é descolada dos painéis. Fonte: Cedoc UnB. 
de Salvador na forma de treliças e, nos hospitais da Rede Sarah Kubitschek ${ }^{25}$. Lima utilizava vigas metálicas com chapas dobradas e soldadas. Em dezembro de 2010 J oão Filgueiras Lima inaugurou o Memorial Darcy Ribeiro em Brasília que utiliza somente material metálico, abandonando a argamassa-armada.

Talvez um ponto determinante na carreira de Lima tenha sido a experiência de Abadiânia, em que ele viveu a execução de obras pré-fabricadas e foi forçado a formar trabalhadores para materializar seus projetos, devido a escassez de verba e de pessoal especializado. Com essa experiência, ficou conhecido como um arquiteto que fabricava componentes, formava pessoal e incorporava a mão-deobra dos trabalhadores na construção civil.

A partir de então passa a construir escolas e equipamentos urbanos. No Rio e em Salvador coordenou a construção dos hospitais da rede Sarah Kubitschek, e muitos outros trabalhos que desenvolveu durante sua carreira.

25 Os trabalhos realizados a partir de 1988 no Centro de Tecnologia da Rede Sarah Kubstschek em Salvador (CTRS), marcaram uma nova fase em que Lima utilizaria maior quantidade de materiais metálicos e diminuiria as peças em argamassa-armada. A cobertura, vigas, pilares, esquadrias, armários técnicos, seriam todos em peças metálicas e as peças de argamassa seriam as divisórias, baldrames, fundações de muro, e anéis de caixa d'água. 


\subsection{Considerações}

A década de 1960 tinha como uma de suas prioridades a expansão industrial no Brasil. O sistema fabril era visto como um meio de racionalizar a produção da construção civil e consequentemente diminuir os custos utilizados para proporcionar um habitat digno para o ser humano.

A industrialização era vista portanto como meio para viabilizar a produção do habitat em larga escala. Para a adequação ao processo seriado, Lima desenvolveu um modo de construção e produção em fábrica, adaptando-se à coordenação modular, ao menor custo e ao mercado consumidor constituído por seus clientes do poder público.

J oão Filgueiras Lima foi formado nessa mentalidade de produção industrial, influenciado por Oscar Niemeyer que lhe trouxe o aprofundamento para se tornar um construtor, por Alvar Aalto que lhe mostrou como fazer arquitetura com conforto climático e, pelo arquiteto e designerArne J acobsen com quem aprendeu a forma de trabalhar nos detalhes minunciosos.

A Teoria Geral de Sistemas, desenvolvida por Ludwig von Bertalanffy pode ser uma teoria capaz de fundamentar o sistema construtivo, dividido em partes para a construção ou fabricação e posteriormente agregadas como um organismo em sua montagem. E também possibilitava o entendimento do ser humano como um todo, visto de forma holística.

O habitat era entendido por Lima como, a "parte de urbanização, de moradia, em todos os complementos sociais que a estrutura exige" (Lima, 2010). O homem e a cidade eram vistos como um sistema composto por subsistemas e a racionalização das construções foi o meio que Lima buscou para proporcionar a igualdade social. A consciência social e coletiva era uma característica comum nos intelectuais da 
década de 1960, trabalhavam por uma sociedade mais justa e pela identidade brasileira. As propostas representadas pelo partido comunistas incentivavam as ações que resultariam na diminuição das desigualdades sociais. A Universidade de Brasília foi palco desses movimentos que durariam até a instalação da ditadura militar em 1964.

A passagem de J oão Filgueiras Lima pela Universidade de Brasília foi essencial para a sua experiência profissional, definiu a visão socialista do arquiteto, assim como seu entendimento da formação dos arquitetos e de novos técnicos no mercado de trabalho. Esse período na UnB também foi determinante para a escolha da construção seriada no seu processo de trabalho.

J oão Filgueiras Lima é um importante exemplo de como a produção industrial era pensada com o intuito de solucionar a demanda por habitat para a população da década de 1960. A fabricação em série era vista como meio para racionalizar, diminuir os custos e proporcionar uma qualidade de vida melhor. Lima estudou, aprimorou e dedicou sua carreira nesse sistema de construção industrializada. 
268 

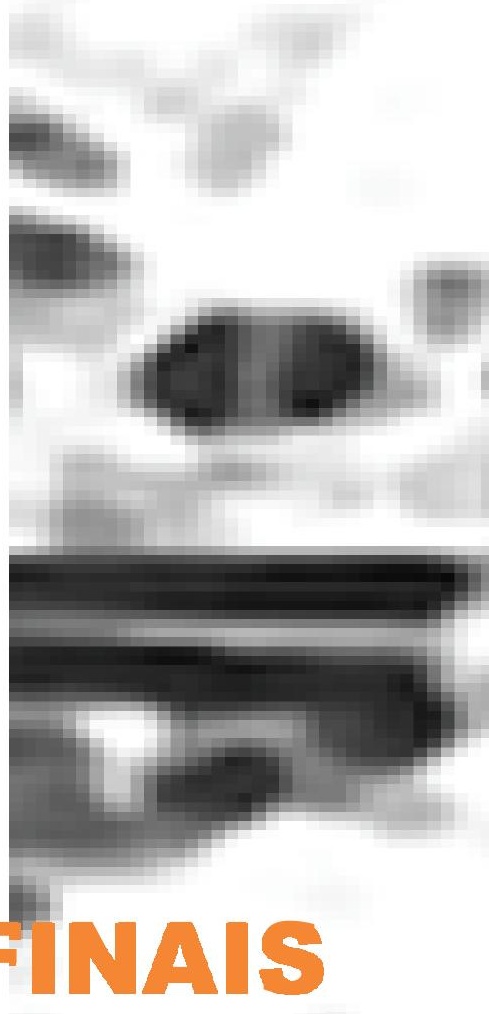

CONSIDERAÇÕES FINAIS

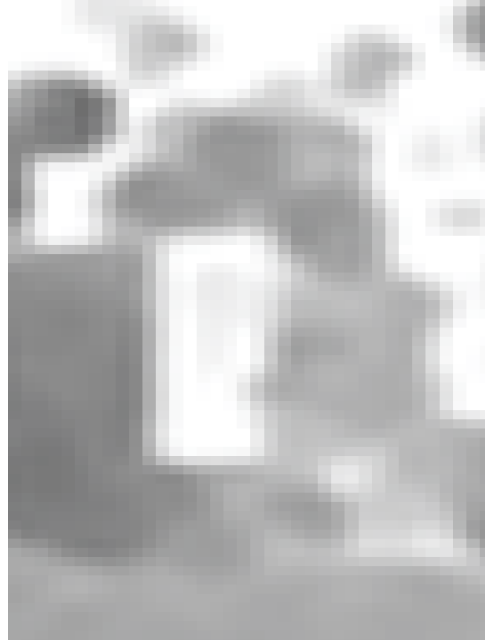


270 
O trabalho procurou abordar três temas interrelacionados como princípios que considera fundamentais para o habitat na década de 1960: as Megaestruturas, as Cápsulas e a forma industrializada de produzi-las. Escolheu como territórios de análise a França, o J apão e o Brasil, e utilizou como exemplo os trabalhos dos arquitetos Yona Friedman, Kisho Kurokawa e J oão Filgueiras Lima.

Preocupou-se em esclarecer as diversas abordagens aos princípios norteadores do habitat, contextualizar o local em que a temática era desenvolvida, conhecer os profissionais que a utilizaram como exemplos, bem como suas referências e fundamentações teóricas e, verificar o que esses arquitetos compreendiam por habitat.

O habitat era entendido de forma sistêmica, como um organismo compostos por partes. As Megaestruturas cumpriam a função de multiplicar o território da cidade e seriam compostas por ambientes coletivos e de cápsulas destinadas a espaços de moradia. Os componentes da cidade seriam produzidos de forma seriada, para atingir a demanda necessária por habitações e construções.

A década de 1960 foi determinante nas modificações da sociedade e dos modos de vida. A influência dos meios de comunicação, associada às teorias da época, foram responsáveis pela modificação da compreensão do espaço da cidade, pela gradativa transformação dos ambientes domésticos, resultando no que Banham chamaria de "A Segunda Era da Máquina".

A publicidade foi intensificada, e se tornou o veículo de disseminação de valores e dos modos de vida, determinando a moda, as condutas, os comportamentos e inclusive os padrões de beleza. A noção de espaço e tempo foi alterada graças aos sistemas de comunicação de massa e às tecnologias desenvolvidas nos transportes. O consumo de produtos e serviços aumentou, incentivando a descartabilidade e consequente renovação constante dos objetos. 
Os arquitetos estudados nesta pesquisa incorporaram as modificações sociais e as reproduziram nas suas propostas. As Megaestruturas eram grandes construções que abrigavam alto contingente de pessoas, e seriam uma maneira de resolver os problemas de moradia e espaço no meio urbano. O habitat era visto como um organismo maior e todas as funções necessárias para a sobrevivência eram realizadas no sistema como um todo: a cidade.

De acordo com a visão do grupo GEAM, do qual Yona Friedman fazia parte, o habitat era a cidade vista como um ambiente diversificado e da coletividade. De acordo com Friedman, as Megaestruturas deveriam utilizar o espaço aéreo urbano e ser organizadas a partir de parâmetros dados pelos arquitetos.

A mobilidade do homem era associada à liberdade, ao ser único e integral. O espaço do habitar era visto como um ambiente individual, propício ao desenvolvimento intelectual e espiritual do ser humano. $O$ ambiente doméstico passou a ser um local com mobiliários funcionais e móveis que previa a modificação do espaço e que abrigava diferentes agrupamentos humanos.

O entendimento do usuário como um ator participativo foi justificado por Friedman, através da associação do comportamento do homem à Teoria da Mecânica Quântica de Heisenberg. Friedman comparava o comportamento do homem à imprevisibilidade do elétron, dizendo que um elétron não ocupava a mesma posição e velocidades na natureza.

As cápsulas produzidas no J apão como formas de habitar eram envoltórios ou invólucros que tornariam a união entre máquina e homem unidades autônomas em estado de simbiose, capazes de sobreviver de forma independente como as cápsulas espaciais. As cápsulas teriam espaços mínimos. As funções necessárias no cotidiano seriam completadas por outros equipamentos da cidade. Eram elaboradas para uma produção seriada e para serem substituídas quando se tornassem obsoletas. 
As cápsulas eram de fácil assimilação para os japoneses que tinham escassez de espaços nas moradias, vistas pelos exemplos de habitação dos períodos anteriores e posteriores à guerra: as casas que eram voltadas para um corredor do período Heian (Kyoto - 794-1186) até o período Edo (Tokyo - 1603-1867), e posteriormente, com a gradativa ocidentalização através do sistema Dinning/Kitchen no século 20. As cápsulas demonstravam um sistema de habitar com a incorporação dos modos de vida ocidentais, evidenciados por Kurokawa, através da cama (bedno desenho) e a altura da escrivaninha que necessitava de cadeiras e não acolchoados para sentar no chão como era costume dos japoneses.

Os Metabolistas tiveram como principais influências o grupo TangeLab, Buckminster Fuller e a Casa do Futuro dos Smithsons. Tinham aproximação com as disciplinas da biologia e acreditavam que a cidade e a arquitetura deveriam ser vistas como um processo metabólico, que crescia, se desenvolvia, se transformava, assimilava, renovava quando necessário e poderia sofrer metamorfose caso não se adaptassem a uma situação diferente.

A proposta de cidade de Kurokawa tinha como princípios a comunicação, o sistema de transportes e a retroalimentação. Era composta com equipamentos que possibilitariam a ordenação do fluxo de pessoas, dos objetos e da informação. As cápsulas tinham a função de espaço do habitar e seguiam os mesmos princípios, eram para o homem com capacidade de alta mobilidade. Possuíam um sistema que possibilitava a comunicação e era capaz de fomecer informações para sua retroalimentação. Esse era o espaço do habitar desenhado por Kurokawa.

O caráter racionalizado, de menor custo e de produção em série da industrialização, desenvolvido no terceiro capítulo, foi largamente incentivado na década de 1960, pois viabilizaria a quantidade de abrigos necessários para à demanda existente. Racionalizar significava adequar à produção, a disponibilidade da matéria-prima, a produção de acordo com a mecanização existente, à mão-de-obra disponível no 
mercado, o transporte até o canteiro de obras e a montagem do edifício.

J oão Filgueiras Lima contribuiu para o processo de produção seriada no Brasil, adaptou-se à coordenação modular, ao desenho industrial e à gestão entre design, produção e montagem. A Teoria Geral de Sistema parece fundamentar a prática fabril através da organização do edifício por subsistemas e da organização da produção.

O habitat era compreendido por Lima como o espaço urbano, composto pelos ambientes coletivos, moradias e equipamentos sociais. A produção seriada era um instrumento para proporcionar uma sociedade mais igualitária e significava realizar a revolução social através da educação e da aplicação do capital em bens sociais.

A consciência social e coletiva fazia parte das intenções dos intelectuais e das políticas voltadas para responder ao Estado de Bem-Estar Social. Tinha o objetivo de uma sociedade mais justa e com identidade brasileira. A experiência atual de J oão Filgueiras Lima é resultante da sua atuação na década de 1960.

Os arquitetos Yona Friedman e Kisho Kurokawa participaram do CIAM X, onde a arquitetura moderna era discutida em um contexto de crise. Suas teorias poderiam ser comparadas aos conceitos desenvolvidos pelo Team $X$, pois se preocupavam em responder às demandas da sociedade emergente. Kurokawa tinha como um dos temas a teoria From the Age of the Machine to the Age of Life (1958), em oposição à era da máquina de Le Corbusier para a era da vida dos Metabolistas. A arquitetura era a forma de expressão e instrumento para atender ao homem da década de 1960: individualista, influenciado pela mídia eletrônica, podendo estar em diferentes locais em pouco tempo e que tinha uma compreensão da vida como efêmera.

As teorias sistêmicas (Teoria Geral de Sistemas, Cibernética e Teoria Matemática da Comunicação, analisadas nesse trabalho) possivelmene foram o pano de 
fundo teórico-metodológico para a compreensão da cidade como espaço do habitat, formado por subsistemas com diferentes funções complementares. As megaestruturas eram idealizadas para cumprir as funções da cidade. A teoria cibernética permitia que a cidade fosse compreendida como local de transmissão de mensagens e meio para a obtenção de dados que retroalimentariam à sua organização.

As teorias científicas foram largamente divulgadas na década de 1960. A TGS queria compreender o sistema para entender o comportamento do mesmo. Já as teorias de comunicação tinham o sistema como uma pré-concepção do fenômeno, mas buscavam compreender os mecanismos internos de transmissão da mensagem para a manutenção do controle do sistema.

Nesse aspecto, apresentaram-se os exemplos das cidades projetadas por Friedman, as moradias utilizando o Flatwriter, o planejamento para Tókio de Kisho Kurokawa e o surgimento das cápsulas com todos os equipamentos necessários para a comunicação e com um sistema de abastecimento de informações criativas feitas pelos usuários, semelhante a internet desenvolvida nos anos 1990.

Embasado na TGS, os edifícios seriam compreendidos em partes e no todo, e a partir disso, a fabricação em série seria capaz de seccionar os diversos componentes que compõem o objeto e as suas estreitas relações entre as partes. A produção seriada de J oão Filgueiras Lima era a perfeita demonstração da produção dos subsistemas e sistemas incentivados no Brasil naquele período.

Em relação ao papel do arquiteto, Friedman compreendia que o arquiteto era responsável por construir um repertório de todas as possibilidades para a constituição do menu que seria oferecido aos usuários, e nesse caso a casa seria organizada a partir de um computador simples que indicaria os parâmetros ao cliente. Kurokawa em seus depoimentos considerava que o arquiteto era responsável pelo desenho e coordenação do processo criativo e de construção de 
seu objeto, preocupava-se com a compatibilização entre os vários agentes, etapas e matérias-prima que seriam utilizadas na construção e montagem das cápsulas.

Segundo os depoimentos de Lima, o profissional arquiteto é responsável por integrar os profissionais e os diversos conhecimentos para a formação do espaço adequado ao ser humano. Essas posturas mostram que tanto Kurokawa como Lima possuíam uma atividade focada mais no âmbito da prática, diferente de Yona Friedman que trabalhou no plano mais teórico.

Observa-se que o trabalho do arquiteto dentro de uma produção sistêmica, analisada neste trabalho, era de elaborar o desenho, coordenar a produção dos componentes e verificar a viabilidade de cada etapa de produção e montagem. Porém, uma vez que esse sistema funcionasse de forma autônoma, o arquiteto poderia se abster do processo, pois o sistema poderia se auto-sustentar. Essa talvez fosse mais uma característica que determinou a modificação da inserção profissional do arquiteto no mercado de trabalho a partir da década de 1960.

Desse modo, o entendimento do habitat pelos arquitetos parece ter se modificado em meados da década de 1960. Agora, parece ser visto como um ambiente no qual muitas variáveis devem ser consideradas. $O$ trabalho do arquiteto, a partir das modificações ocomidas nesse período, passa a ser compreendido não somente como ambiente construído, mas como habitat composto com diversas disciplinas e conhecimentos. 


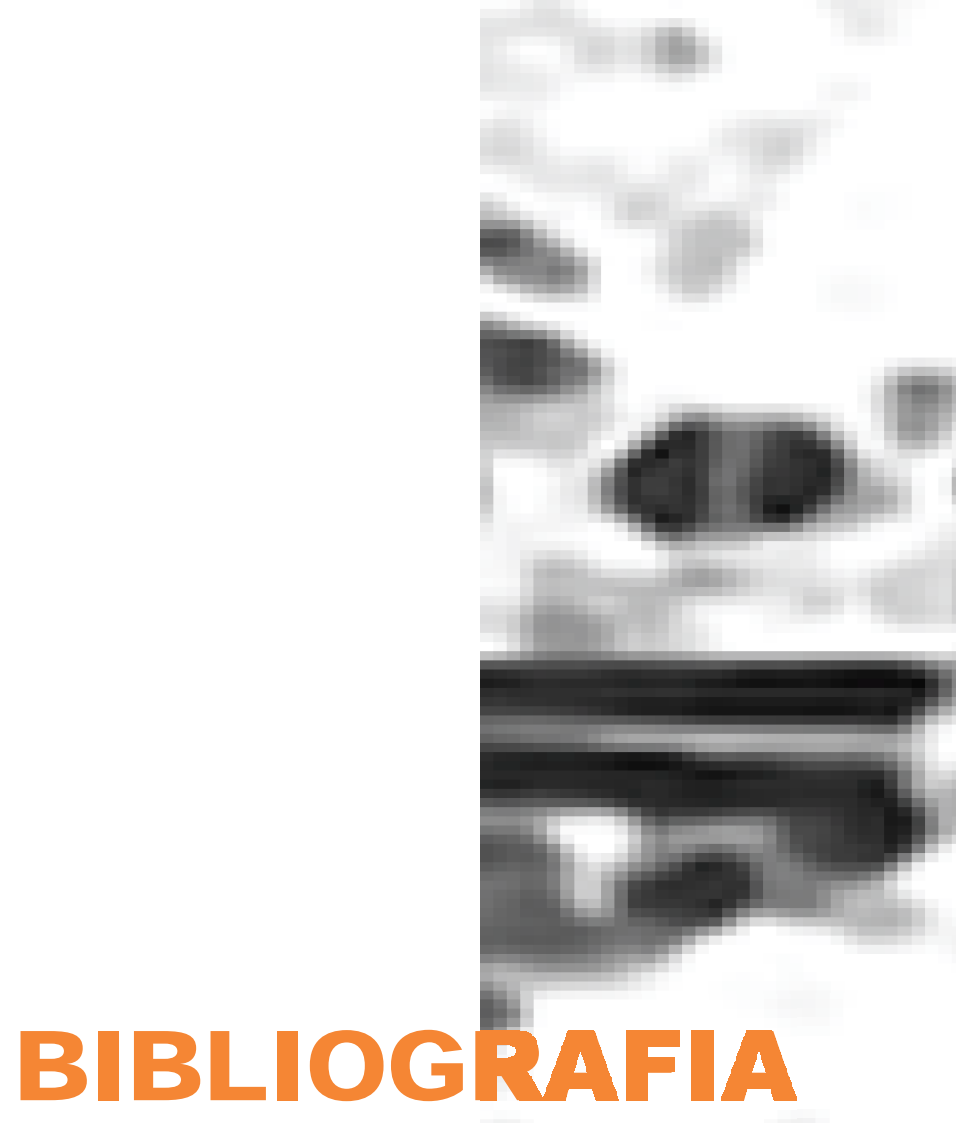


AALTO, A. (1970).Synopsis: painting Architecture Sulpture, Basel: Birkhäuser AG.

ABRAHAMS, T. and FRIEDMAN, Y. (2009).Interview: Yona Friedman, Blueprint Magazine, . Disponível em: ‘tttp://www.blueprintmagazine.co.uk/index.php/ everything-else/interview-yona-friedman>. Acesso em: 23 mar 2010.

ALBERTO, K.C. (2009). A pré-fabricação e outros temas projetuais para campi universitário na de cada de 1960: o caso da UnB, Revista de Pesquisa em Arquitetura e Urbanismo - Risco, no. 10 . p. 80-90.

ARANTES, O. B. F. (1998). Urbanismo em fim de linha e outros sobre o colapso da modernização arquitetônica, São Paulo: Editora da Universidade de São Paulo.

ASHBY, W.R. (1960). Design for a Brain: the origin of adaptive behavior, New York: J ohn Wiley \& Sons. Inc.

BANHAM, R. (1969). Home is not a house, Architectural Design, v. 39 jan. p. 45-48. . (2001). Megaestruturas: futuro urbano del pasado reciente, Barcelona: Editorial Gustavo Gili. (1ª. Edição 1978) . (1979). Teoria e Projeto na Primeira Era da Máquina, São Paulo:

Editora Perspectiva, p. 499-515.

BEER, S. (1974). Cybernetics of Cybernetics or The Control of control and The communication of communication, The Cybernetician, no. 8, Report no. 71.38 Urbana, Illinois.

BERTALANFFY CENTER FOR THE STUDY OF SYSTEMS SCIENCE (2010). General System Theory The Nature of Systems. Disponível em: বhttp://www.bertalanffy. org/c_25.html>Acesso em: 06 de jan de 2010.

BERTALANFFY, L. Von (1975). Teoria Geral de Sistemas, Tradução de Francisco M. Guimarães, Petrópolis: Vozes. 
BOYD, R. (1962). Kenzo Tange, New York: George Braziller.

BRAYER, (2010). The Frac Center, Disponível em: «ttp://www.mori.art.museum/ english/contents/archilab/about/index.html>. Acesso em: 25 abr 2010.

BRETON, P. \& PROULX, S. (2002). Sociologia da comunicação, Tradução: Ana Paula Castellani, São Paulo: Loyola.

BRIGGS, A., BURKE, P. (2002). Uma História social da Mídia: de Gutenberg à Internet. Rio de J aneiro: J orge Zahar.

BRUNA, P. (1970). Subsídios para uma política da construção no Brasil, Acrópole, no. 380, ano 32, p. 32-37. . (1976). Arquitetura, Industrialização e desenvolvimento, São Paulo:

Perspectiva.

BUSBEA, L. (2007). Topologies, The urban Utopia in France, 1969-1970. Cambridge: The MIT Press.

CARRANZA, E.G.R. (2004). Eduardo Longo na Arquitetura Moderna Paulista 19612001. 2004. 388p. Dissertação (Mestrado em Arquitetura e Urbanismo) Universidade Presbiteriana Mackenzie, São Paulo.

CDCC. (2010). "Século XX - Astronomia e Astronáutica O Homem na Lua. Disponível em ঝttp://cdcc.sc.usp.br/cda/sessao-astronomia/seculoxx/textos/o-homem-nalua.htm >. Acesso em: 08 set 2010.

CHOAY, F. (2000).O urbanismo, série estudos, São Paulo: Perspectiva.

DAWSON, C. \& STANTON, A. (1969). Another Alternative, Architectural Design, no. 39, p. 374.

DESIGN MUSEUM, ARCHIGRAM (2007). Architects (1961-1974). Disponível em: বhttp://designmuseum.org/design/archigram>. Acesso em 23 mai 2010. 
DIAS, C. B. (1970). A Estrutura da Universidade de Brasília, Acrópole, n 369, p. 13-39. DONNELLY, T. (2010). YONA FRIEDMAN EXHIBITION , No. 152, City, Main, Portikus, Sachsenhausen, 2008. Disponivel em: 丸ttp://www.portikus.de/ArchiveA0152.html>. Acesso em: 26 abr 2010.

EKERMAN, S. K. (2005). "Le oeuvre multiforme de Lelé". Lausanne, Tracés, $\mathrm{n}^{\circ}$ 15/16, ano 131, 17 agosto 2005, p. 26-28. Versão em Português publicada na Revista Vitruvius, Arquitextos, como "Um quebra-cabeca chamado Lelé". São Paulo, set. 2005. Disponível em: 〈http://www.vitruvius.com.br/revistas/read/ arquitextos/06.064/423>. Acesso em: 01 out 2010.

ELOHIMJ L, E. (2010). Systems Science: is it necessary?, Disponivel em: ‘http://www. bertalanffy.org/media/pdf/pdf1.pdf>acessado em: 06/01/2010.

ENGEL, H. (1985). The Japanese House: A tradition for contemporary architecture, Rutland, Vermont, Tokyo: Charles e. Tuttle company: publisher. (first edition 1964)

FERREIRA, A. B. de H. (1986). Novo dicionário da língua portuguesa, 2a. Ed. Revista e aumentada, Rio de J aneiro: Ed. Nova Fronteira.

FLUSSER, V. (1983). Nossa Morada in FLUSSER, V. Pós-História, vinte instantâneos e um modo de usar, São Paulo: Duas Cidades, p.73-79.

FORSÉ, M. ET.AL. (1993). Recent Social Trends in France, 1960-1990, Paris, McGillQueen's University Press.

FRAM PTON, K. (1997). História Crítica da Arquitetura Moderna, São Paulo: Martins Fontes.

FRANÇOIS, C. (1999). Systemcs and Cybernetics in a Historical Perspective, Systems Research and Behavioral Science, 16, p. 203-219.

FRIEDMAN, Y. (1973). Hacia una arquitectura científica Versión española de Francisco Ayguavives Gárnica, Madrid: Alianza Editorial. 
(2006). Pro Domo. Barcelona: Actar and J unta de Andalucia. . (1977). Utopias Realizáveis, Lisboa: Socicultur.

GIEDION, S. (2004). Espaço, Tempo e Arquitetura: O desenvolimento de uma nova tradição. Tradução de Alvamar Lamparelli. São Paulo: Martins Fontes.

GHIRARDO, D. (2002). Arquitetura contemporânea: Uma história concisa, Tradução: Maria Beatriz de Medina, São Paulo: Martins Fontes.

GORDON, T.J . (1967) The effects of technology on man's environment, Architectural Design, v. 37, n.2.

GUIMARÃES, A.G.L. (2003). João Filgueiras Lima: o último dos modernistas. 2003. 196p. Dissertação (Mestrado em Tecnologia do Ambiente Construído) - Escola de Engenharia de São Carlos, Universidade de São Paulo, São Carlos.

HARVEY, D. (1989). Condição Pós-Moderna: uma pesquisa sobre as origens da Mudança Cultural, Tradução: Adail Ubirajara sobral e Maria Stela Gonçalves, 3a. Ed, São Paulo: Ed. Loyola.

HEIDEGGER, M. (2006). Construir, Habitar, Pensartradução: Marcia Sá Cavalcante Schuback In: Ensaios e Conferências, Tradução: Emmanuel Carneiro Leão, Gilvan Fogel e Marcia Sá Cavalcante Schuback, 3a. Petrópolis: Ed. Editora Vozes, Editora Universitária São Francisco.

HEISENBERG, W. (1996). A parte e o todo: Encontros e conversas sobre física, filosofia, religião e política, Tradução de Vera Ribeiro; revisão da tradução Luciana Muniz e Antonio Augusto Passos Videira; revisão técnica Ildeu de Castro Moreira, Rio de J aneiro: Contraponto.

. (1999). Física e filosofia, Tradução de J orge Leal Ferreira, Brasília:

Editora Universidade de Brasília, 4ạ. Ed. Edições Humanidades. (Primeira edição 1958) 
HERTZBERGER, H. (1999). Lições de Arquitetura, Tradução: Carlos Eduardo Lima Machado, São Paulo: Martins Fontes.

HIGUCHI, K. (1961).Restore Man and Nature to Architecture, The Japan Architect, no. 2, v. 36 .

HOBSBAWM, E. (1995). Era dos extremos: O breve século XX - 1914-1991, Tradução de Marcos Santarrita, Revisão técnica: Maria Célia Paoli, 2a. Ed. São Paulo, Companhia das Letras.

HOFKIRCHNER, W. (2009). Ludwig von Bertalanffy Forerunner of Evolutionary Systems Theory ICT\&S Center for Advanced Studies and Research in Information and Communication Technologies \& Society, University of Salzburg, SigmundHaffner-Gasse 18, A 5020 Salzburg, Austria and Bertalanffy Center for the Study of Systems Science, c/o Vienna University of Technology, Favoritenstraße 9/187, A 1040 Vienna, Austria. oct 2009.

HOUAISS, A. VILLAR, M. de S.; FRANCO, F.M. de M. (2004). Dicionário Houaiss de Lingua Portuguesa, Rio de J aneiro: Editora Objetiva.

HUIZINGA, J . (2000). Homo Ludens, Tradução: J oão Paulo Monteiro, São Paulo: Perspectiva, Disponível em: \tttp://groups.google.com/group/digitalsource>. Acesso em: 12 dez 2010.

ISHII, K. \& SUZUKI, H. (1977). Post-Metabolism, The Japan Architect, no. 247, oct-nov 1977

ISOZAKI, A. (2004). Arata Isozaki, GA Document Special Issue, no. 77, feb. 2004. KAWAZOE, N. (1967). Topological Spaces, The Japan Architect, no. 137, p. 77-78 KOJ IRO, Y. (1959). J apanese Architecture in 1958 - New Vitality, The Japan Architect, no. 1, v. 34. . (1964). Spaces without Ceilings, The Japan Architect, no. 96, p. 73- 
80.

. (1970). Houses Screaming for Recognition, The Japan Architect,

no. 45, p. $61-63$.

KOURY, A. P. (2007). Arquitetura construtiva: proposições para a produção da arquitetura no Brasil (1960-1970), Projeto História, São Paulo, n.34, p. 189-203 KUROKAWA K. (2010). Project for a Helix City, Tokyo: Office Summer Break, August. Disponível em: ‘ttp://www.kisho.co.jp/ page.php/200>. Acesso em 18 set 2010. . (1972). Challenge to the capsule The Japan Architect, no. 190,

October.

. (2006). Kisho Kurokawa: From The Age of the machine to the age of life, The International Magazine Architecture, Design and Visual Communication, no. 219, Milan.

. (1977). Metabolism in Architecture, London: Studio Vista.

. (1987). New Tokyo Plan, 2025 - the city of Symbiosis The Japan

Architect, no. 62, nov/dec.

. (1995). The architecture of the age of life principle, The Japan

Architect, no. 18.

. (1967). Two systems of Metabolism, The Japan Architect, no. 12, v.

137.

LATORRACA, G. (2000). João Filgueiras Lima - Lelé; São Paulo: Instituto Lina Bo e Pietro Maria Bardi.

LE CORBUSIER (2000). Planejamento Urbano, Tradução de Lúcio Gomes Machado, São Paulo: 3ạ. Ed. Perspectiva.

LEGGERINI, M. R. C. \& KALIL S. B. (2011). Estruturas Isostáticas - DECivil . PUCRS. 
Disponível em: বttp://www.pucrs.br/feng/civil/professores/kalil/isodec5(2003-2). pdf $>$. Acesso em 05 fev 2011.

LEY, S. van der \& RICHTER M., (2011).Megastructure Reloaded, 2006. Disponível em: বhttp://www.megastructure-reloaded.org/en/megastructure/ >. Acesso em: $21 \mathrm{dez}$ 2010.

LIMA, J .F. (1963). Apartamentos para professores, Revista Módulo, no. 32, ano VIII, mar, p. 39-41.

. (2004). 1933- O que é ser arquiteto: memórias profissionais de Lelé (João Filgueiras Lima); em depoimento a Cynara Menezes. Rio de J aneiro: Record. . (2007). J OÃO FIL GUEIRAS LIMA, LELÉ, [ENTRE]Entrevistas com arquitetos por estudantes para estudantes e interessados em arquitetura. Entrevista realizada por Adriano Carneiro de Mendonça em 18 de janeiro de 2007, no Centro Tecnológico da Rede Sarah, Salvador, BA. Publicação em 01 dez 2009. Disponível em «ttp://www.entre.arq.br/? $p=1017>$ Acesso em 27 nov 2010

MAKI, F. (1964). Investigation in Collective Form, A Special Publication, The School of Architecture, St. Louis: no. 2.

MAKI, F. (1994). Notes on collective form, The Japan Architect, v. 16 no.1, p. 247-297. . (1987). To offer unforgettable Scenes: A discussion with Fumihiko Maki, entrevistado por Roger Connah, The Japan Archtect, Tokyo, v. 62, no. 359, mar, p.68-72.

MASUDA, Y. (1982). 1909 - A sociedade da informação como sociedade pósindustrial, Tradução de Kival Charles Weber e Angela Melim. Rio de J aneiro, Ed. Rio. MATTELART, A. (2002). História da sociedade da informação, Tradução de Nicolás Nyimi Campanário, São Paulo: Loyola.

McHALE, J . (1967). Man + Architectural Design, v. 37, n.2, feb. 
MCLUHAN, M. (2007). Os meios de comunicação como extensões do homem, Tradução de Décio Pignatari, São Paulo: Cultrix.

MENDES, I. M. (1964). Projeto do Arquiteto Filgueiras - S4 ,Brasília: Cedoc.

MONTANER, J . M. (2008). Sistemas arquitetónicos contemporáneos, Barcelona: Gustavo Gili. . (1995). Después del movimiento moderno: Arquitectura de La segunda mitad Del siglo XX. Barcelona: Arctectura ConTextos, 2a. Ed., Editorial Gustavo Gili.

MORIN, E. (1977). O método, a natureza da Natureza, São Paulo, Publicações Europa-América.

MORSE, E. S. (1886). Lares Japoneses: Seus Jardins e Arredores, Tradução: Mário Salviano, Nórdica, Rio de J aneiro.

MÜHL, H. R.von der. (1979). Kenzo Tange, Barcelona, Editorial Gustavo Gili.

MULEJ M. et. AL. (2004). How to restore Bertalanffian systems thinking, Kybernetes, Vol. 33, p.48 - 61 .

MURAI, M. (1966). A view of Modern J apanese Architecture - 20 years after the war, The Japan Architect, no. 120, jun, p. 87-107.

NIEMEYER, O. (1963). Escritório do Ceplan, Revista Módulo, no. 32 ano VIII, mar, p. 26-31. . (1963). Instituto de Ciências, Revista Módulo, no. 32 ano VIII, mar, p.

34-38.

NISHIYAMA, U. (1963). J apanese Houses, The Japan Architect, no. 9, v. 98.

NOBRE, A. L. (2008). Fios Cortantes: Projeto e Produto, arquitetura e design no Rio de Janeiro (1950-70), Tese (Doutorado em História Social da Cultura), Departamento de 
História, Pontifícia, Universidade Católica do Rio de J aneiro, 2008.

NOMADS.USP. (2010). Habitat Disponível em: 〈http://www.nomads.usp.br/site/ pesquisa/apresentacao.htm $>$. Acesso em : 02 mai 2010.

OLIVERI, G.M. 2002. Prefabricazione o metaprogetto edilizio, Milão, Etas-Kompass, 1968. Apud BRUNA, P. Arquitetura, Industrialização e Desenvolvimento, São Paulo: Perspectiva.

ONOBAYASHI, H. (1967). The Architectural Theory of Noriaki Kurokawa, The Japan Architect, no. 12, v. 137.

PASK, G. (1961). An approach to cybernetics. Londres: Hutchinson \& CO. LTD. . (1969). The Architectural Relevance of Cybernetics, Architectural

Design, v. 39, sep.

PIÑA, I. B. \& ZAVALA E. O. (2010). DIRECTED EVOLUTION? PHILOSOPHICAL SYSTEMIC REFLECTIONS disponível em: বttp://www.bertalanffy.org/media/pdf/ pdf2.pdf $>$ acessado em 07 out 2010.

PORTO J R. F.G.R. (2001). Anísio Teixeira: Vida, Obras e Movimento, Rev. Educ. Pública, v.10, no. 18, jul-dez, p. 124-140

PORTOGHESI, P. (2002). Depois da Arquitetura Moderna, Tradução e apresentação de Ana Luiza Nobre, São Paulo: Martins Fontes.

PRICE, C. (1966). Potteries Thinkbelt, Architectural Design, no. 66, p. 484.

RIBEIRO, D. (1963). Papel e função da Universidade de Brasília na luta pelo desenvolvimento, Revista Módulo, no. 32, ano VIII, mar.

RIDENTI, M. (2002). Em busca do Projeto intelectual brasileiro: O sonho acabou? Entrevista realizada por Alvaro Kassab da Universidade Estadual de Campinas, dez 2002. p. 6-7 Disponível em: ‘ttp://www.unicamp.br/unicamp/unicamp_hoje/ 
jornalPDF /202pgs0607.pdf>Acesso em 27 out 2010.

RIDENTI, M. (2000). Em busca do povo Brasileiro - artistas da revolução, do CPC a era da TV.Rio de J aneiro: Editora Record.

ROSCOE, K. (1971). Exploração Submarina, Tradução de Fernando de Castro Ferro, São Paulo, Edições Melhoramentos.

ROSSO T. (1969). Introdução à coordenação modular, Acrópole, no. 364, ano 31, ago, p. 34-39 . (1990). Racionalização da Construção, São Paulo. Universidade de São Paulo, Faculdade de Arquitetura e Urbanismo.

SAKURAI, C. (2007). Os Japoneses Ed. Contexto, São Paulo.

SALES, J . R. (2000). Partido Comunista do Brasil. PC do B: propostas teóricas e práticas políticas (1962-1976). 2000. 251p. Dissertação. (Mestrado em História). Instituto de Filosofia e Ciências Humanas, Universidade Estadual de Campinas, Campinas.

SCANDINAVIAN DESIGN (2010). Arne Jacobsen, Disponível em: বhttp://www. scandinaviandesign.com/ arne_jacobsen/>Acesso em: 27 out 2010.

SCHOECH, (2004). Concept Paper: Systems Theory, U. of TX at Arlington School of Social Work, , 18-Aug-04, Page 1 - 5 Disponível em: ‘ttp://www2.uta.edu/cussn/ courses/ 3306/coursepack/theory_systems.pdf>. Acesso em: out 2009.

SCOTT, B. (2004). "Second order cybernetics: an historical introduction", Kybernetes, v.33, n. 9/10, p. 1365-1378.

SEGAWA, H. (2002). Arquiteturas no Brasil 1900-1990São Paulo: Editora da Universidade de São Paulo.

SEIROKU, N. (1967). The heritage of Japanese art Tokyo: Kokusai Bunka Shinkokai. 
SERRA S. M. B.; FERREIRA M. de A. e PIGOZZO B. N., (2005). Evolução dos Préfabricados de Concreto, Anais do 1ㅇ. Encontro Nacional de Pesquisa-ProjetoProdução em Concreto Pré-Moldado, São Carlos, SP, nov.

SEVCENKO, N. (2001). A corrida para o século XXI: no loop da montanha-russa, São Paulo: Companhia das Letras- (Virando séculos; 7).

SHANNON, C.E. and WEAVER, W. (1949). The mathematical theory of communication, Urbana: The University of Illinois press.

SMITHSON, P. \& SMITHSON, A. (2010). Manifesto Doorn. Disponível em: $\varangle$ www. team10online.org/team10/text/doom-manifesto.htm>. Acesso em: 26 abr 2010.

SUZUKI, S. (1994). Mente Zen, Mente de Principiante tradução: Odete Lara, São Paulo, Palas Athena.

TANGE, K \& ISOZAKI, A. (1971). Directions in Today's Architecture: A discussion between Kenzo Tange and Arata Isozaki, The Japan Architect, no. 7, v. 45.

TANGE, K. (1962). Creation in Present-day Architecture and the Japanese Tradition, in: BOYD, R. Kenzo Tange New York: George Braziller.

THIS IS A HOUSE? British house of the Future. (1956). Mechanix I/lustrated, Sept. 1956. Disponível em:<http://blog.modernmechanix.com/2006/08/10/british-houseof-the-future/?Qwd=/ Mechanixlllustrated/9-1956/future_house\&Qif=future_house_0. jpg\&Qiv=thumbs\&Qis=XL\#qdig $>$. Acesso em: 22 Sept. 2010.

THOMPSON, J . B. (1999). A mídia e a modernidade : uma teoria social da mídia, Tradução de Wagner de Oliveira Bandão, Revisão da Tradução: Leonardo Avritzer, Petropolis: 2a. ed, Vozes.

TRAMONTANO, M. (1998). Paris, São Paulo, Tokyo: novos modos de vida, novos espaços de morar. Tese de Doutorado. São Paulo: FAU-USP.

Von FOERSTER, H. (1974). Cybernetics by Norbert Wiener Cybernetics of 
Cybernetics or The Control of control and The communication of communication The Cybernetician, no. 8 B.cC.L. Report no. 71.38, Sponsorores by a Grant from The Point Foundation to The biological computer Laboratory University of Illinois Urbana, Illinois, may. . (2007). Self-organizing systems and their environments: Essays on Cybernetics and Cognition, in: Understanding Understanding, Springer New York, New York, P. 1-19.

WEBB, M. \& GREENE, D. (1966). Drive-in housing, Architectural Design, no. 36, nov, p. 573.

WHITELEY, N. (2002). Reyner Banham: historian of the immediate Future, London: The MIT Press.

WIENER, N. (1954). Cibernética e Sociedade: O uso Humano de Sêres Humanos, Tradução de J osé Paulo Paes, São Paulo: Cultrix.

YOSHIODA, Y (ed.) (1960). Spetial Feature Short History of Contemporary J apanese Architecture, The Japan Architect, v. 35 no. 11/1960. p. 93-96. 

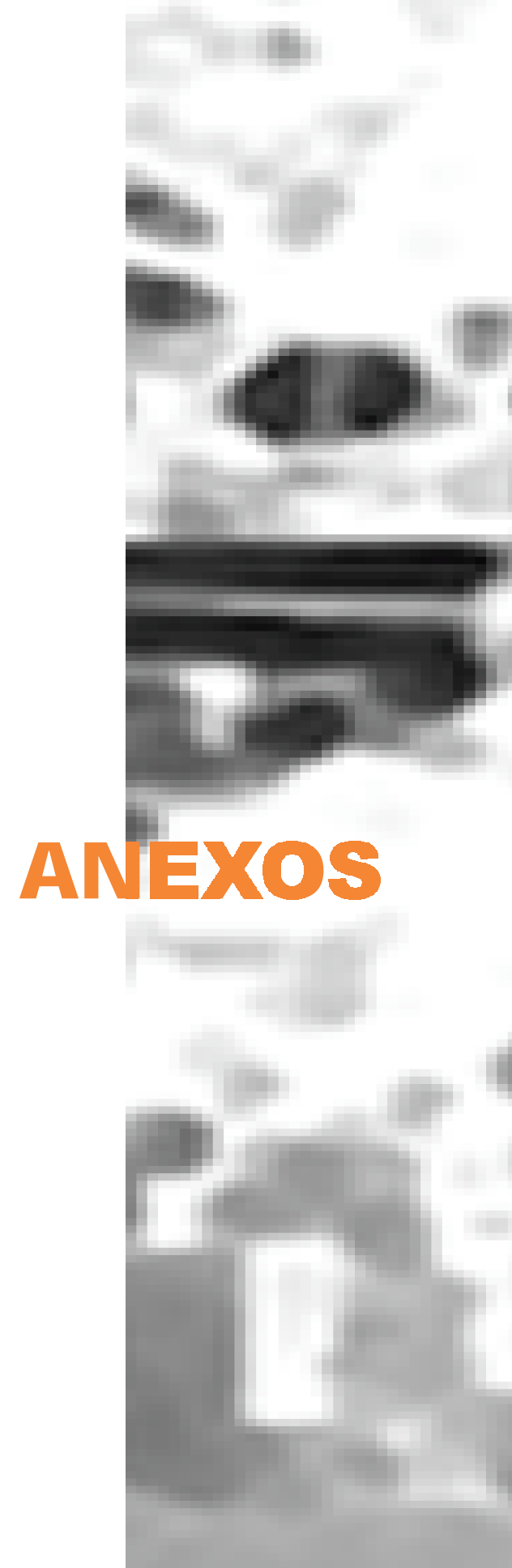
292 


\subsection{Manifesto Doorn}

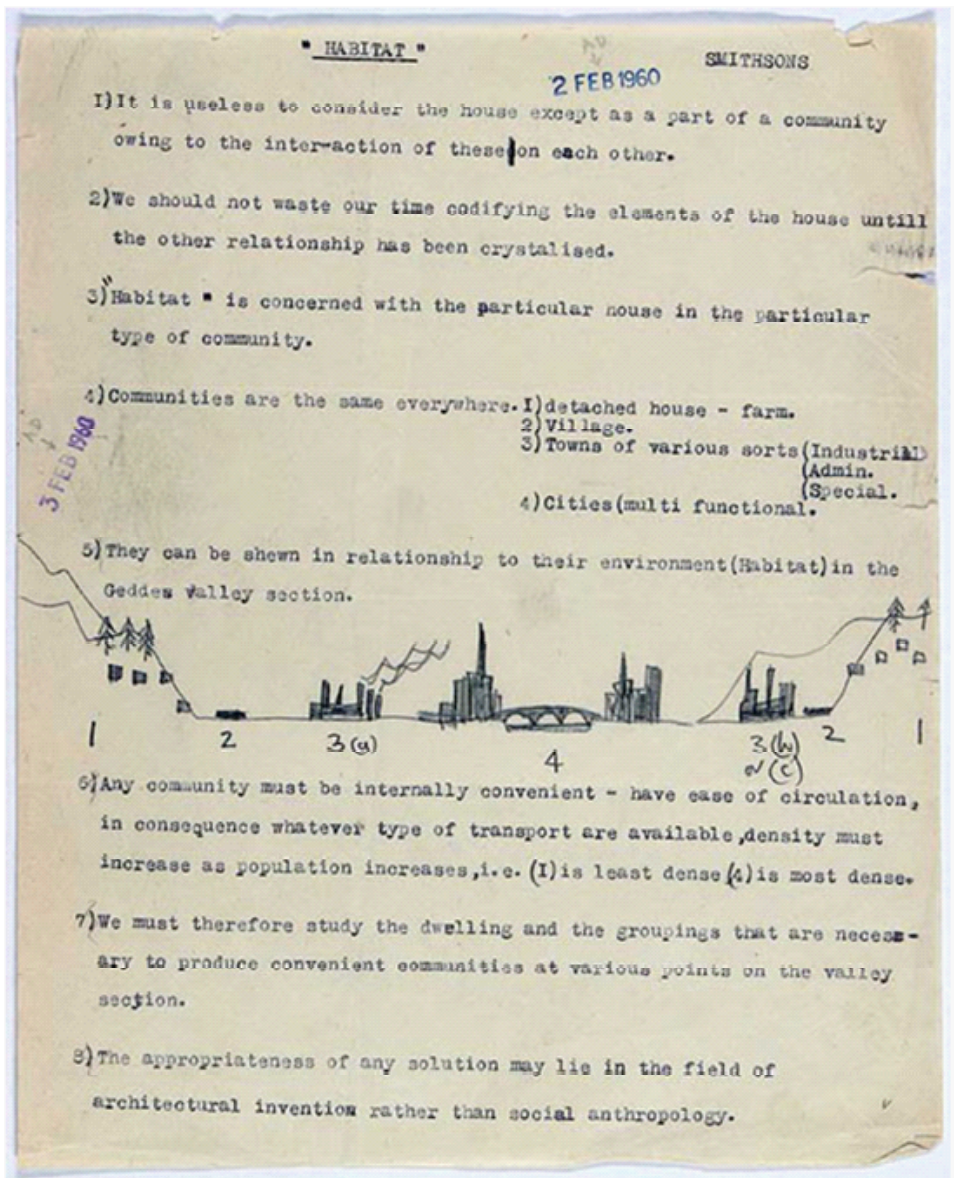

Figura 144: Manifesto Doorn - Disponível em: http://www. team10online.org/team10/text/ doorn-manifesto.htm data de acesso 09 mai 2010 
a. Existing constructions are not adapted to contemporary life. The increase or decrease of populations is not taken into account. Nor is the extraordinary increase in the rate of circulation. The laws and rapports of property ownership are outdateand rigid. The price of building is too high. Methods of urban planning do not respond to the rapid increase in knowledge and technology. (BUSBEA, 2007, P. 63)

b. All of these observations explain the disequilibrium of modern urban life: congested circulation, shortage of apartments and the failure of existing apartments to adapt to the needs of families, urban exodus on the weekends; isolation of a great number of inhabitants of the city. (BUSBEA, 2007, P. 63)

c. GEAM proposes: the reform of property laws to attain the greatest facility of exchange, of the property as much as its usage; the increasing use of variable and interchangeable constructions; the increasing use of variable and interchangeable constructions; the possibility for the inhabitants to participate in a personal manner in the formation of the habitable spaces that can adapt themselves to any individual need; prefabrication and industrialization to maintain low prices; the densest possible structure of different parts of the city, comprising dwellings, places of work, and sport and culture. (BUSBEA, 2007, P. 63)

d. To realize these propositions, GEAM will devote itself to study of the following techniques: 1 . Construction of elements of habitation thatare variable and interchangeable, including the mobility of exterior facades, interior walls, floors and ceiling. 2 . The possibility of evolutivity of supply networks for energy, water, and waste disposal. 3. The development of unites d'habitation of sufficient size and significance to constitute cities in and of themselves: buildings in the form of bridges; interchangeable containers [that] can circulate, fly, float; floating buildings; climatization of large spaces. (BUSBEA, 2007, P. 63)

The theoretical concerns:

The social transformation of cities requires a radical revision of techniques of urbanism and construction; the growing terrestrial population requires an extraordinary rhythm of construction; transformations in technology (circulation, telecommunications, productions, etc.) lead to unforeseeable exigencies. GEAM carries out research on the adaptation of techniques of habitation to this situation: to render cities and dwellings elastic, mobile. Like all research, the routes followed vary, but the goal is the same: to alleviate the current rigidity of urban life via the intervention of more appropriate techniques of habitat. (BUSBEA, 2007, P. 64) 


\subsection{Declaração GEAM - 1960}

a. Construções existentes não estão adaptados à vida contemporânea. O aumento ou a diminuição das populações não é levado em conta. Nem é o extraordinário aumento da taxa de circulação. As leis e relatórios de propriedade são obsoletas e rígida. O preço do prédio é muito alto. Métodos de planejamento urbano não respondem ao rápido aumento no conhecimento e na tecnologia.

b. Todas essas observações explic am o desequilíbrio da vida urbana moderna: circulação congestionada, falta de apartamentos e do fracasso de apartamentos existentes para se adaptar às necessidades das famílias, o êxodo urbano nos finais de semana; isolamento de um grande número de habitantes da cidade.

b. GEAM propõe: a reforma das leis de propriedade para alcançar a maior facilidade de troca, da propriedade, tanto quanto a sua utilização, o uso crescente de construções de variáveis e intercambiáveis, o uso crescente de construções variáveis e intercambiáveis; a possibilidade de os moradores para participar de uma forma pessoal na formação dos espaços habitáveis que podem se adaptar a qualquer necessidade individual; pré- fabricação e industrialização de manter os preços baixos, a estrutura mais densa possível de diferentes partes da cidade, incluindo residências, locais de trabalho, esporte e cultura . p. 63

c. Para realizar estas proposições, GEAM irá dedicar-se ao estudo das seguintes técnicas: 1. Construção de elementos da habitação que são variáveis e intercambiáveis, incluindo a mobilidade das fachadas exteriores, paredes interiores, chão e teto. 2. A possibilidade de evolução das redes de abastecimento de energia, água e eliminação de resíduos. 3. O desenvolvimento de uma habitação de dimensão suficiente e significado para as cidades constituem em si mesmas: edifícios em forma de pontes; recipientes intercambiáveis [que] podem circular, voar, flutuar; edifícios flutuantes; climatização de grandes espaços.

As Preocupações teóricas

A transformação social das cidades exige uma revisão radical de técnicas de urbanismo e construção, o crescimento da população terrestre requer um ritmo extraordinário de construção; transformações na tecnologia de circulação (telecomunicações, produção, etc) conduzir a exigências imprevisíveis. GEAM realiza pesquisas sobre a adaptação de técnicas de habitação para essa situação: para tornar as cidades e as habitações elásticas, móveis. Como todas as pesquisas, as rotas seguidas variam, mas a meta é a mesma: para aliviar a rigidez atual da vida urbana através da intervenção de técnicas mais adequadas de habitat. 


\subsection{Documento de Ismael Magalhães Mendes}

Documento apresentado na íntegra. Disponível no Centro de Documentação da Universidade de Brasília. Documentos do Ceplan. Levantado em jan 2011.

Sr. Presidente e demais membros da CCEBB,

- PROJ ETO DO ARQUITETO FILGUEIRAS - SQ

Encaminho à consideração de V.Ss. o projeto do Arquiteto SR. Filgueiras, cumpre-nos expender as seguintes considerações:

1. O partido adotado para a construção foi o de concreto pré-moldado, parcialmente protendido.

2. O Arquiteto conta com boa experiência no assunto, pois vem desenvolvendo o projeto da Universidade de Brasília, em concreto pré-fabricado e protendido.

3. Conta, outrossim, com idêntica experiência do plano urbanístico e arquitetônico de Brasília, porquanto aqui vem trabalhando desde o início da construção da cidade, estando perfeitamente familiarizado com as exigências e posturas locais.

4. Arquiteto jovem, considerado, com muita justiça, dos mais talentosos da nova geração, esteve, recentemente, em demorada visita a diversos países da Europa, onde colheu dados importantes sobre a arquitetura moderna e novas técnicas de construção.

5. O pré-fabricado deixou de ser aventura no ramo de construção, pois além da experiência estrangeira de mais de uma década, no Brasil, grandes construtoras como a Rabello, Ribeiro Franco e a Cristiani Nielsen, já vêm adotando o sistema, com pleno êxito.

6. O pré-moldado é a primeira tentativa séria de industrializar a construção civil e melhorar-Ihe a produtividade, pois, atualmente, os métodos de trabalho são os mais rudimentares.

7. Cada vez o percentual de fôma de madeira (material e mão-de-obra) vem pesando mais no custo do metro cúbico do concreto, eis que as reservas de madeira são praticamente não renováveis, dado o longo período exigido para sua substituição, e o valor crescente do salário real e leis sociais. No préfabricado a economia com fôrma é substancial dado o reaproveitamento da mesma fôrma algumas dezenas de vezes. A economia de mão-de-obra também é grande, pois a concretagem é feita em posição muito mais cômoda, ao nível do chão.

8. No pré-fabricado não existe a despesa de escoramento. Existe, apenas, o transporte vertical das peças acabadas, enquanto, por outro lado, deixa de existir o transporte vertical de fôrmas, armações e concreto.

9. No concreto protendido as despesas com armações fic am reduzidas, praticamente, a metade, além de reduzir o volume de concreto. Avalio em $20 \%$ a economia proporcionada pelo sistema pré- 
moldado de estrutura e protendido, face ao concreto convencional. Como o volume de concreto a ser consumido numa [...]

10. A partir disto, como o pré-moldado permite acabamento muito superior, em muitas superfícies ficaria dispensado o acabamento com revestimento de argamassa e pintura ou com revestimentos especiais. A economia deste item - substancial, só poderia ser avaliada com o projeto concluído.

11. Finalmente, devo considerar que a industrialização da construção civil é um imperativo do desenvolvimento nacional, pois só assim poderíamos aumentar a produtividade do fato trabalho, condição indispensável a qualquer forma de desenvolvimento econômico. Deveria, pois, o Banco, como entidade pública, acelerar esse processo de industrialização, a exemplo do que já vem fazendo as Universidades de São Paulo e de Brasília, mesmo que ainda tenha de pagar alguma "taxa de aprendizagem" pelo processo ainda pioneiro no Brasil.

Ismael Magalhães Mendes

Engenheiro Civil

Brasilia (DF) 20 de janeiro de 1964 
298 


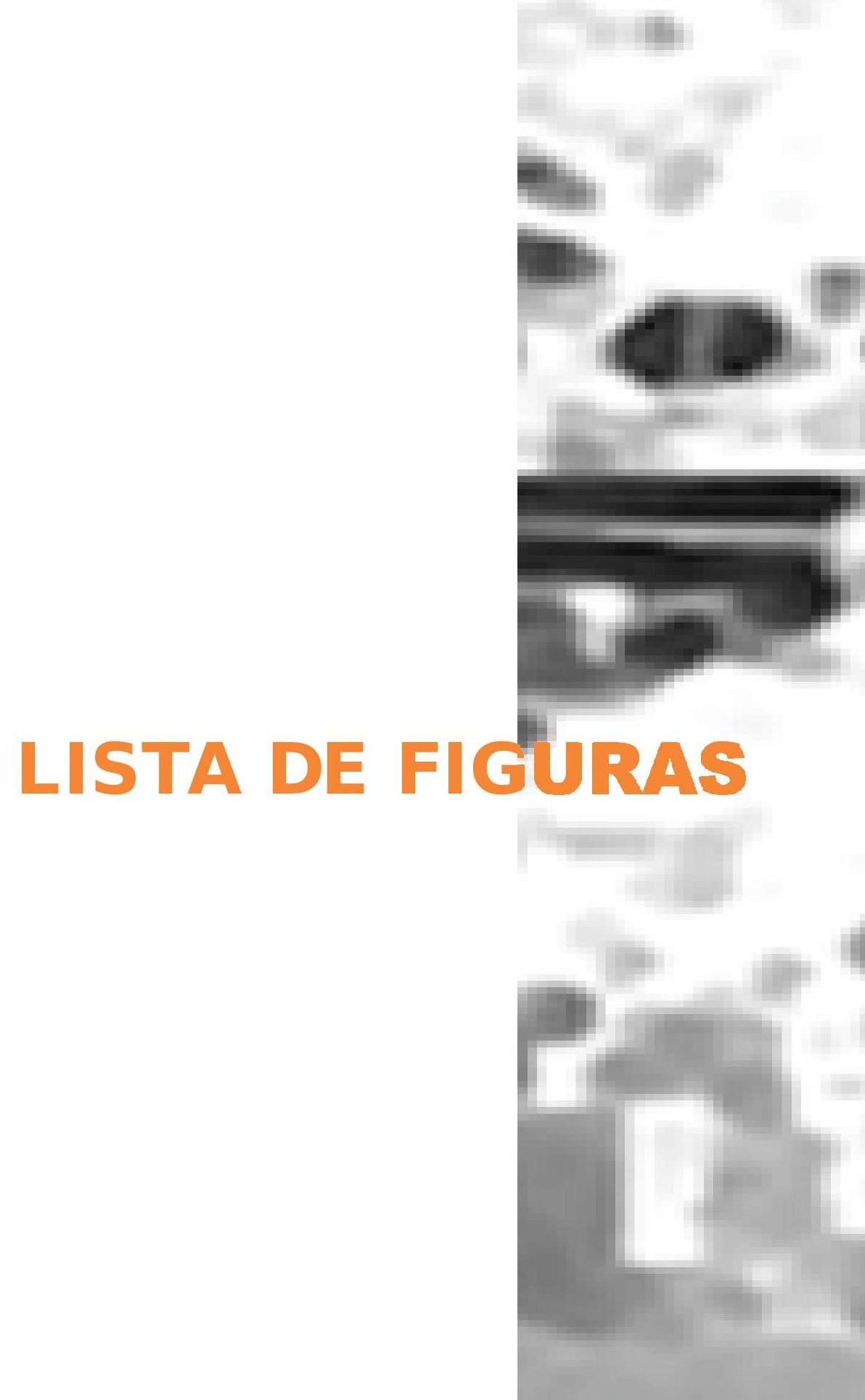


300 
Figura 1: A home is not a house. Fonte: (BANHAM, 1969, p. 46.).

Figura 2: Habitat e seu contexto.

Figura 3:Segundo colocado:Takefumi Aida and Itsuo Kamiya. Maquete das habitações modulares. Fonte: The Japan Architect, n. 126, p. 42..

Figura 4: Primeiro colocado: Akira Shibuya. Vista da união entre Megaestruturas e planta do espaço do habitar. Fonte: The JapanArchitect, n. 126, p. 32.

Figura 5: Exemplo de ilustração. Fonte: (FRIEDMAN, 2006, contracapa)...............40

Figura 6: Paris Espacial (1959) Fonte: (FRIEDMAN, 2006, p. 312).

Figura 7: Nova rota através de Medina, Tunis (1959) Fonte: (FRIEDMAN, 2006, p. 299).

Figura 8: Uma proposta relativa a Nova lorque (1964) Fonte: (FRIEDMAN, 2006, p. 2 79).

Figura 9: O guarda-chuva sobre Les Halles (1969). Fonte: (FRIEDMAN, 2006, p. 28 7).

Figura 10: Um museu que modifica a cada exposição (1970) Fonte:

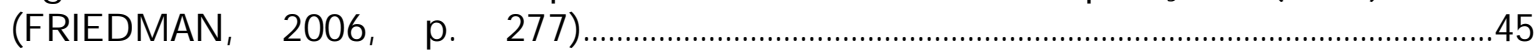

Figura 11: Tel-Aviv ponte da paz (1990) Fonte: (FRIEDMAN, 2006, p. 283)..........45

Figura 12: Berlim (2004) Fonte: (FRIEDMAN, 2006, p. 29)...........................................46

Figura 13: Monte Carlo (1980) Fonte: (FRIEDMAN, 2006, p. 302)............................46

Figura 14: Paul Maymont - Projetos de vilas espaciais, vilas flutuantes e vilas subterrâneas.

Figura 15:FreiOtto:modelosuspenso para estaçãoferroviária deStuttgart,Alemanha.....51

Figura 16: David Georges Emmerich - Future City Experimentand Utopia in Architecture 19562006. . .52

Figura 17: Jerzy Soltan YMCA International Camp Site, Pune. 52

Figura 18: Werner Ruhnau - Museu de Arte de Gelsenkirchen. "As artes plásticas e eventos de teatro musical em Gelsenkirchen". 
Figura 19: Constant - New Babilon é uma cidade flutuante sobre uma estrutura existente.

Figura 20: Eckhard Schulze-Fielit, Raumstadt, 1959. 700 x 700 x 1350 mm. Collection FRACCentre,France.Photo:Philippe Magnon.

Figura 21: Yona Friedman, Spatial City, Tunis (1960). Courtesia Yona Friedman. Fonte: (BUSBEA, 2007, p. 66).

Figura 22: Princípio 1. Fonte: (FRIEDMAN, 2006, p. 65) ......................................................65

Figura 23: Princípio 2. Fonte: (FRIEDMAN, 2006, p. 65).....................................................66

Figura 24: Principio 3. Fonte: (FRIEDMAN, 2006, p. 66)................................................66

Figura 25: Principio 4 Fonte: (FRIEDMAN, 2006, p. 66) ................................................67

Figura 26: Princípio 5 Fonte: (FRIEDMAN, 2006, p. 67)........................................................67

Figura 27: Princípio 6 Fonte: (FRIEDMAN, 2006, p. 67).....................................................68

Figura 28: Princípio 7. Fonte: (FRIEDMAN, 2006, p. 68) ......................................................68

Figura 29: Princípio 8 Fonte: (FRIEDMAN, 2006, p. 68)..........................................................69

Figura 30: Princípio 9 Fonte: (FRIEDMAN, 2006, p. 69).....................................................69

Figura 31: Princípio 10. Fonte: (FRIEDMAN, 2006, p. 69).............................................70

Figura 32: Nicholas Schöffer, Cybernetic City (1955), rendering Courtesy Eléonor

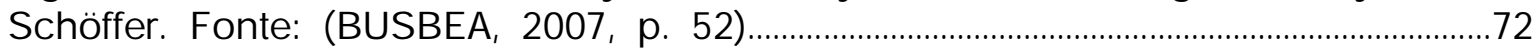

Figura 33: Casa feita com planos curvos. O mesmo painel serve como elemento de fechamento e cobertura. (Israel, 1953). Fonte: (FRIEDMAN, 2006, p. 12)....................78

Figura 34: Yona Friedman with J ean-Pierre Pecquet, Cylindrical Shelters (1958). Courtesy Yona Friedman. Fonte: (BUSBEA, 2007, p. 66)

Figura 35: Diagrama explicativo do processo de design convencional Fonte: (FRIEDMAN, 1973, p.18).

Figura 36: Diagrama de processo de projeto tradicional associado ao aumento de população. Fonte: (FRIEDMAN, 1973, p.21). . .81 
Figura 37: Diagrama de Shannon \& Weaver (1948). Fonte: (SHANNON, \& WEAVER, W. 1949).

Figura 38: Diagrama do processo de produção do habitat. Fonte: (FRIEDMAN, 1973, p.23).

Figura 39: Diagrama das responsabilidades do arquiteto e competências dos usuários. Fonte: (FRIEDMAN, 1973, p.25)...

Figura 40: Tipologias de ambientes para configuração do habitat Fonte: (FRIEDMAN, 1973, p. 7). . .88

Figura 41: Resultado da escolha do usuário Fonte: FRIEDMAN, 1973, p. 71 89

Figura 42: Tradução dos modos de vida e uso dos ambientes da habitação Fonte: FRIEDMAN, 1973, p. 72.

Figura 43: Planta da infraestrutura que acolherá 0 habitat. (FRIEDMAN, 1973, 72) 92

Figura 44: Ilustração do ambiente para o projeto Fonte: Revista Manchete Edição especial, abril 1965, apud NOBRE, 2008, p. 269......................................96

Figura 45: Sugestão da cidade do Rio do Futuro. Fonte: Revista Manchete Edição especial, abril 1965, apud NOBRE, 2008, p. 272.

Figura 46: Rio do Futuro - 1965 Fonte: Revista Manchete - Edição especial, abril 1965, apud NOBRE, 2008, p. 274.

Figura 47: Sérgio Bernardes, Hotel Tropical (Recife) - 1968. Fonte: Revista Manchete

- Edição especial, abril 1965, apud NOBRE, 2008, p. 277.

Figura 48: Operação 'Tectile, a $15 \mathrm{~m}$ de profundidade llhas Virgens. Fonte: (ROSCOE, 1971, p. 110). 106

Figura 49:LivingPod(1965)David Greene.Fonte:Disponivelem: বttp://www.archigram. net/projects_pages/living_pod.html $>$. Acesso em: 22 set 2010. Greene. 109

Figura 50: Capsule Homes (1964) Warren Chalk. Fonte: Disponivel em: বhttp:// www. archigram.net/projects_pages/capsule_homes_4.html $>$. Acesso em: 22 set 2 010. 
Figura 51: Cushicle (1966-1968) Mike Webb. Fonte: Disponivel em: <http:// www.archigram.net/ projects_pages/cuishicle_3.html>. Acesso em:

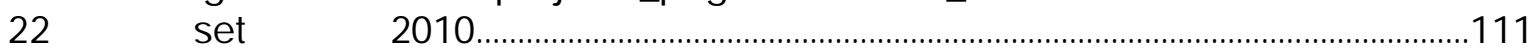

Figura 52: Conformação das casas no período Edo. Fonte: (NISHIYAMA, 1963, p. 29). Reprodução do desenho Camila Borghezan...............................................................114

Figura 53: Cidade: rua do Comércio. Fonte: arquivo pessoal....................................115

Figura 54: Mercadores Era Taishô - espaço comercial voltado para a rua. Fonte: acervo pessoal.

Figura 55: Corredor interno dos quartos locados. Fonte: (NISHIYAMA, 1963, p. 29).

Figura 56: Área de cocção de uma casa urbana (toriniwa) antes da era do imperador Meiji (1868-1912). Fonte: (NISHIYAMA, 1963, p. 29).

Figura 57: Casa frontal, (da esquerda para a direita) comércio, sala íntima e sala posterior. Fonte: (NISHIYAMA, 1963, p. 29)..

Figura 58: Planta casa tradicional japonesa da figura ao lado. Fonte: (NISHIYAMA, 1963, p. 29)...

121

Figura 59: Casa mínima. 1. Estar e cozinha, 2. Zashiki (quarto), 3. Area de estudo. Fonte: (NISHIYAMA, 1963, p. 30).

Figura 60: Distribuição do número de cômodos das habitações da cidade e da área rural em 1930. Fonte: (NISHIYAMA, 1963, p. 30).

Figura 61: Planta 2DK dividia em área de dormir e área de comer. Fonte: NISHIYAMA, 1963, p. 31) 124

Figura 62: Planta de 47,01 m2, 1. Sala de estar e dormir, 2. Sala de estar e dormir, 3. Cozinhar e comer, 4. Entrada, 5. Banheiro, 6 Armário. Fonte: (NISHIYAMA, 1963, p. 31.) Reprodução do desenho: Camila Borghezan. .126

Figura 63- Templo japonês construído com modulação de tatami. Fotoacervo pessoal 127

Figura 64: Maquete e corte do prédio para unidade de habitação. Desenvolvido 
no Massachusetts Institute of Technology - Cambridge 1959-60. Fonte: (MÜHL, 1979. p. 11).

Figura 65: Estudo sobre a disposição do quarteirão de Tsoukiji (1960-64) . Fonte: (MÜHL, 1979. p. 15).

Figura 66: Arranha-céus para apartamentos em Tehera s/d. Fonte: (MÜHL, 1979. p. 26)

Figura 67: Vila agrária. Fonte: (MAKI, 1964, p. 263)....

Figura 68: Dymaxion House. Fonte: Disponível em: বhttp://www.bfi.org/> Acesso em: 18 set 2010

Figura 69: Foto Maquete Dymaxion House. (1927-1930). Fonte: Disponível em: বhttp://greatdesigners. wordpress.com/2008/11/08/great- designer-r-buckminsterfuller> Acesso em: 18 set 2010.

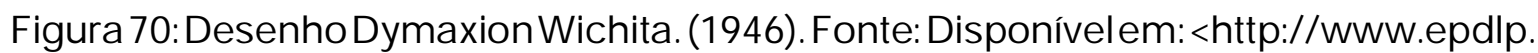
com/fotos/buckminster2.jpg > Acesso em: 18 set 2010.

Figura 71: Poster da exposição This is Tomorrow. Fonte: (THIS IS A HOUSE?, 2006)

Figura 72: House of the Future , 1956. Fonte: (THIS IS A HOUSE?, 2006) 141

Figura 73: Projeto Tokyo Bay (1960) - Kenzo Tange Fonte: (MÜHL, 1979. p. 26). 146

Figura 74: Projeto Helix City (1961) - www. Kisho.co.jp 147

Figura 75: Proposta para bairro de Shinjuko Tokyo (1964) - Fumihiko Maki. 148

Figura 76: City in the Air (1962) - Arata Isozaki. Fonte: (ISOZAKI, 2004, p.144) 149

Figura 77: The Sky House (1959) - Kiyonori Kikutake. Fonte: (KOJ IRO, 1958, p. $113-118)$

Figura 78: Marine City (1960) - Kiyonori Kikutake. Fonte: Disponível em: বhttp:// www.kikutake.co.jp/e/top/top.html>. Acesso em: 16 set. 2010.

Figura 79: Matomatchi Apartments (1972), Masato Otaka. Fonte: Disponível em: ‘ttp:// landarchy.org/metabolists/images.html\#maki>. Acesso em 18 set 2010. 
Figura 80: Movement Diagram - Kiyoshi Awazu. Fonte: MAKI, F. Investigation in Collective Form, A Special Publication, The School of

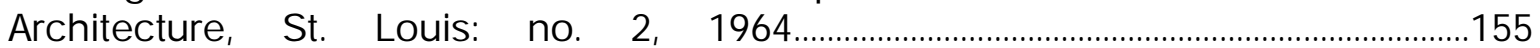

Figura 81: Cidade Nova de Hishino (1966) - Localizada próxima a cidade de Nagoya, o projeto abriga 30.000 pessoas. Fonte: Disponivel em:

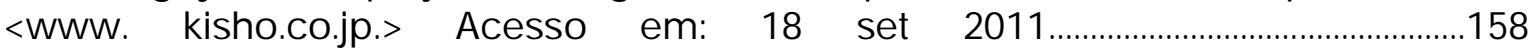

Figura 82: New Tokaido Rail System - projeto de tráfego para o plano de Kurokawa, fonte: (KUROKAWA, 1967, p. 54). 166

Figura 83: Rede Metropolitana do J apão, com investimento prioritário nas principais cidades de todo território japonês. Fonte: (KUROKAWA, 1967, p. 54) 167

Figura 84:Rededecapitais formada em três pontos,Kyoto (palácio real eca pital cultural), Nogoya e Osaka (ministérios) Fonte: (KUROKAWA, 1967, p. 55). 168

Figura 85: North Staffordshire -área do Potteries Thinkbelt. Fonte: (PRICE, 1966, p. 484).

Figura 86: Tetsuya Akiyama, Iwao Kawakami, Norio Sato and Yuji Shiraishi. Menção Honrosa no concurso Residential Design Competition de 1966. Fonte: The Japan Architect no. 126 de 1966, p. 44-45. 172

Figura 87: Foto da maquete publicada em 1971. Fonte: Nakagin Capsule Tower, publicado na revista The J apan Architect, v. 174, 1971. p. 3.

178

Figura 88: Planta da cápsula Nakagin Business . Fonte: The J apan Architect, oct 1972. p. 29. Reprodução do desenho: Camila Borghezan 180

Figura 89: Componentes do corpo e estrutura; banho e ar condicionado. Fonte: The Japan Architect, october, 1972.p. 29. Reprodução do desenho: Camila Borghezan.................................181

Figura 90: Corte da cápsula Nakagin Capsule Tower. Fonte: The J apan Architect, oct, 1972.p. 27. Reprodução do desenho: Camila Borghezan. 182

Figura 91: Corte da cápsula Nakagin Capsule Tower. Fonte: The Japan Architect, oct, 1972.p. 27. Reprodução do desenho: Camila Borghezan. 183

Figura 92: Bolas voadoras, (1980) Eduardo Longo. Bolas voadoras, (1980) 
Eduardo Longo. Fonte: Disponível em: «ttp://www.eduardolongo.com/ bolBV2.html> Acesso em: 28 set 2010...............................................188

Figura 93: Bolas voadoras, (1980) Eduardo Longo. Bolas voadoras, (1980) Eduardo Longo. Fonte: Disponível em: «ttp://www.eduardolongo.com/ bolBV2.html>. Acesso em: 28 set 2010.

Figura 94: Peruíbe/Amauri (1972) Eduardo Longo. Peruíbe/Amauri (1972) Eduardo Longo . Fonte: Disponível em: «tttp://longoeu.sites.uol.com.br/ pa70-04.html>. Acesso em: 28 set 2010.

Figura 95: Desenho de divisórias - Oscar Niemeyer. Fonte: (NIEMEYER, 1963,

p. 27).. 198

Figura 96: Ceplan. Foto: Acervo Pessoal, (30/12/2010) 199

Figura 97: Fotos da montagem e canteiro de obras Ceplan. Fonte: (NIEMEYER, 1963,

p. 200

Figura 98: Canteiro de obras Ceplan Fonte: (NIEMEYER, 1963, p. 27) .202

Figura 99: Planta Alojamento de professores UnB, 1. Circulação, 2. Estar, 3. Quartos, 4. Q. Empregada, 5. Banheiro, 6. Banheiro empregada, 7. Cozinha, 8. Área Serviço, 9. Despensa, 10. Depósito. Fonte: (LATORRACA, 2000, p. 36). 211

Figura 100: Sala Estar com armário divisor de ambientes. Alojamento de professores. Foto: Acervo Pessoal. Foto tirada em 30/12/2010. 212 Figura 101: Bellavista, Klampenborg (1931-1934). Fonte: Arne J acobsen 215 Figura 102: Desenho cortesia KAB Desenho para a Casa do Futuro (1929). Fonte: Arne Jacobsen....................................................215

Figura 103: "The Ant" and "The Number Seven". Fonte: Arne J acobsen.........................215

Figura 104: Cama-maca automatizada desenvolvida por J oão Filgueiras Lima CTRS (07/2010). Fonte: acervo pessoal.

Figura 105: Croqui de montagem dos alojamentos de professores da UnB - Lajes protendidas, vigas longitudinais, núcleo fundido no local. Desenho J oão Filgueiras Lima (2010). Fonte: acervo pessoal. 
Figura 106: Unidade pré-moldada para habitação, autoria de Oscar Niemeyer (1962), desenho de Klaus Chaves Alberto. Fonte: (ALBERTO, 2009. p. 81).

Figura 107: Etapas de aquisição da unidade de habitação industrializada (45 m2 - 42 ton.). Fonte:Rev.Módulo no.27, 1962, p.32-croqui de OscarNiemeyer.

Figura 108: Organização verticalizada das unidades de habitação com jardim entre as habitações. Fonte: Rev. Módulo no. 27, 1962, p. 34 - croqui de Oscar Niemeyer................................................................233

Figura 109: Localização da Universidade de Brasília no Plano Piloto da cidade. Fonte Ceplan UnB...........................................................................236

Figura 110: Plano original da UnB. Fonte: Cedoc (UnB)................................................238

Figure 111: Maquete da atual Universidade de Brasília. Fonte: foto tirada da maquete localizada na reitoria na UnB. Acervo Pessoal (dez 2010)

Figura 112: Vista aérea UnB - Alojamento de Professores. Fonte: Cedoc UnB 240

Figura 113: Vista Geral dos Apartamentos. Fonte: Cedoc UnB 241

Figura 114: Vista Leste. Fonte : Ceplan UnB 242

Figura 115: Vista Oeste. Fonte: Ceplan UnB 242

Figura 116: Planta 1 - Alojamento Coletivo. Estar, quartos, varanda, banheiro coletivo, quartos, cozinha, área serviço e varanda. Fonte Ceplan UnB.

Figura 117: Planta 2 - Três quartos. Estar e jantar, varanda escritório, quartos, banheiro, cozinha, quarto serviço, banheiro serviço e área de serviço. Fonte Ceplan UnB........................................245

Figura 118: Planta 3 - Dois quartos. Estar, varanda, quartos, banheiro, quarto opcional para serviço, cozinha, serviço, depósito e lixo. Fonte Ceplan UnB. 246

Figura 119: Planta 4- Um quarto - estar, escritório conjugado, varanda, quarto, banheiro, cozinha, área serviço e banheiro de serviço. Fonte Ceplan UnB. 247

Figura 120: Peça cobogó face oeste. Fonte: Cedoc UnB 248

Figura 121: Peça esquadria face leste. Fonte: Cedoc UnB. 248 308 
Figure 122: Vedação de cobogó e viga com instalações aparentes. Fonte: acervo pessoal. 249

Figura 123: Corte Longitudinal - escada. Fonte Ceplan UnB 250

Figura 124: Corte transversal - escada. Fonte Ceplan UnB. 250

Figura 125: Corte transversal. Fonte Ceplan UnB .251

Figura 126: Colocação da viga "U". Fonte: Cedoc UnB .252

Figure 127: Quarto com viga aparente e rótula Gerber. Divisão entre ambientes de painel. Fonte: acervo pessoal... 252

Figura 128: Caixa de escada. Fonte: Cedoc UnB .254

Figura 129: Colocação das vigas. Fonte: Cedoc UnB .254

Figura 130: Sistema estrutural, colocação das vigas. Fonte: Cedoc UnB 255

Figura 131: Viga transportada por guindaste. Fonte: Cedoc UnB 255

Figura 132: Laje nervurada pré-moldada.Fonte: Cedoc UnB...................................256

Figura 133: Colocação de laje de piso. Fonte: Cedoc UnB..........................................256

Figura 134: Elevação face pinos e painel de vedação. Fonte: Cedoc UnB.................258

Figura 135: Relação viga estrutural e pilar. Fonte: Cedoc UnB........................................258

Figura 136: Colocação segunda laje. Fonte: Cedoc UnB,............................................259

Figura 137: Colocação painéis laterais de vedação. Fonte: Cedoc UnB.......................260

Figura 138: Face leste escada. Fonte: Cedoc UnB..........................................................261

Figura 139: Pintura do edifício. Fonte: Cedoc UnB..........................................................261

Figura 140: Vista interna do apartamento, face do armário. Fonte: Cedoc UnB

Figura 141: Vista interna do apartamento, face da esquadria. Fonte: Cedoc UnB 262

Figura 142: Escada pavimento térreo e piso pré-fabricado. Fonte: Cedoc 


\section{UnB}

264

Figura 143: Escada pavimento térreo. Detalhe da escala; do lado oposto ao corrimão a escada é descolada dos painéis. Fonte: Cedoc UnB................................264

Figura 144: Manifesto Doorn - Disponível em: http://www.team10online.org/ team10/text/doom-manifesto.htm data de acesso 09 mai 2010..........................293 